\author{
Sliz Mariann
}

SZEMÉLYNÉVTÖRTÉNETI VIZSGÁLATOK A KÖZÉPKORI MAGYARORSZÁGRÓL 



$$
\text { Sliz Mariann }
$$

\section{SZEMÉLYNÉVTÖRTÉNETI VIZSGÁLATOK A KÖZÉPKORI MAGYARORSZÁGRÓL}

Magyar Nyelvtudományi Társaság

Budapest

2017 
Sliz Mariann

Személynévtörténeti vizsgálatok a középkori

Magyarországról

Lektorálta: B. Gergely Piroska és Gerstner Károly

A kiadvány alapjául szolgáló kutatást a Bolyai János Kutatási

Ösztöndíj támogatta.

A kötet megjelenését a Nemzeti Kulturális Alap támogatása tette lehetővé.

\section{$\Pi<a$}

Nemzeti Kuiturâlis Alao

C Slíz Mariann, 2017

ISBN: 978-615-5061-12-7 (nyomtatott)

ISBN: 978-615-5061-13-4 (online)

DOI: $10.26546 / 5061134$

Borítóterv: Szabó Panna és Slíz Mariann

Kiadta a Magyar Nyelvtudományi Társaság

1088 Budapest, Múzeum krt. 4/A 


\section{TARTALOM}

1. A KÖTET TÉMÁJA, FORRÁSAI ÉS MÓDSZEREI ................................................13

1.1. A kötetben feldolgozott források és témák ………………………………………....13

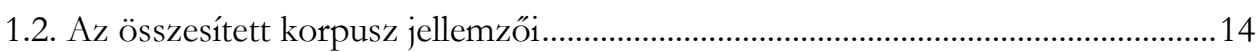

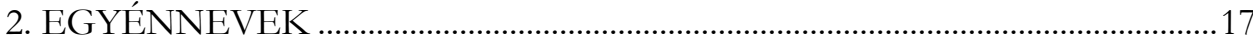

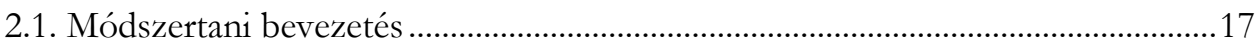

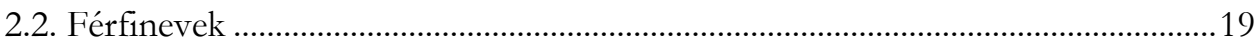

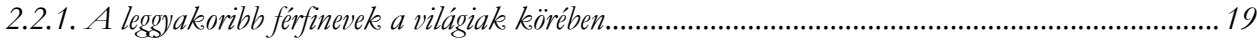

2.2.2. A névállomány eredet szerinti megoszlása az egyes rétegekben .........................................................20

2.2.3. A leggyakoribb nevek népszerüségének idöbeli változása a birtokosok körében .............................. 24

2.2.4. A névállomány eredet squerinti megoszlásának változása a birtokos rétegekben...............................27

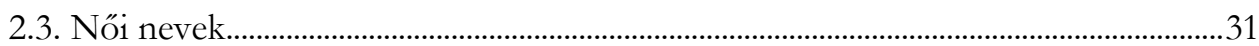

2.3.1. A leggyakoribb nöi nevek a különbözö rétegekben …………………………………………....... 31

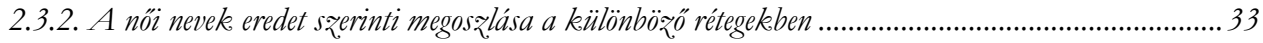

2.3.3. Az úrnök névállományának idóbeli változása eredet szerint .......................................................35

2.4. A jövevénynevek változatai ............................................................................................37

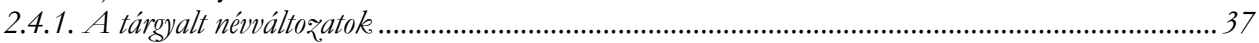

2.4.2. A névváltozatok elhatárolásának problémái ..............................................................................42

2.4.3. A névváltozatok oklevélbeli arányának idóbeli változása .............................................................44

2.4.4. A névváltozatok oklevélbeli arányának társadalmi megoszlása..................................................46

2.4.5. Latin alapnevek és vulgáris változataik összefüggése: egyedi jellemzők ........................................48

2.4.6. Egyes névváltozatok hasznosíthatósága a jo-/ju- > i- változás vizsgálatában .............................. 51

2.5. A genealógia tanúsága ..................................................................................................56

2.5.1. A genealógia szerepe a személynévtörténeti kutatásokban ............................................................5 56

2.5.1.1. A genelógia sz̨erepe a néveredet meghatározásában ...................................................................5 57

2.5.1.1.1. Módszertani megjegyzések a néveredet meghatározása kapcsán ...............................................57

2.5.1.1.2. A Jolánta név eredete: a genealógia tanúsága .....................................................................59

2.5.1.2. A házassági kapcsolatok hatása a nevek terjedésére a középkori magyar nemesség körében.........64

2.5.1.3. A nevek öröklödésének jellemzöi a középkori magyarországi nemesség körében ........................... 67

2.5.1.4. Az irodalmi eredetü egyénnevek vizsgálata az öröklödés szempontjából ..................................... 75

\section{MEGKÜLÖNBÖZTETŐ NÉVELEMEK ÉS CSALÁDNEVEK........................81}

3.1. Formai szempontok alkalmazhatósága a történeti családnevek vizsgálatában........81

3.1.1. Aq alapkérdés...................................................................................................... 81

3.1.2. 14. századi oklevelek és 16. száąadi összeirások személyjelölö szerkęzeteinek összevetése:

1. virsgálat. 
3.1.3. 14. sqáąadi oklevelek és az 1332-1337-es pápai tizedjegyzékek névadatainak összevetése: 2. virsgálat.....

3.1.4. Három 16. sqázadi forrástípus névadatainak össqevetése: 3. vizsgálat............................................ 85

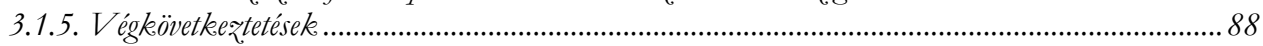

3.2. A megkülönböztető névelemek és az oklevélírói gyakorlat ..................................8 88

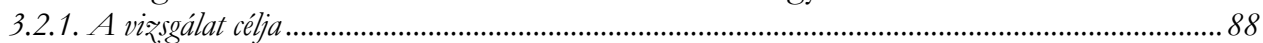

3.2.2. Az élöszóbeli névhasználat jelentkezése a hivatalos irásbeliségben ................................................. 89

3.2.2.1. Az élöszóbeli névhasz̨álat jelentkęzése az egyénnevekben ……...................................................90

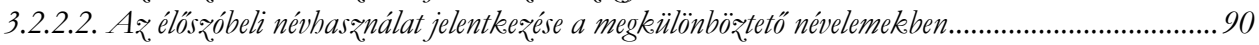

3.2.2.2.1. A dictus-szal kapcsolt sqerkezetek ........................................................................................ 91

3.2.2.2.2. A rokon nevéböl eredô megkëlönböztetö névelemek ...................................................................92

3.2.2.2.3. A helynévi eredetü megkë̈lönbö̈ztetö névelemek ...................................................................... 94

3.2.3. A helynévi eredetü megküilönböztetö névelemekeel kapcsolatos egyéb kérdések.................................94

3.2.3.1. A helynévi eredetü megkeülönböztetón névelemek cserélödése az egyénnév mellett ..............................94

3.2.3.2. Több helynévi eredetû megkülönböztetô névelem az egyénnév mellett............................................96

3.2.4. Az adatok elemzésének tanulságai ......................................................................................97

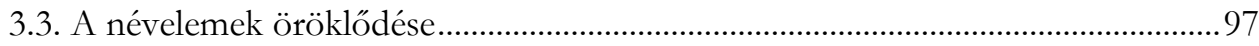

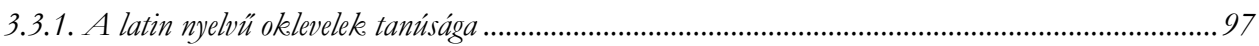

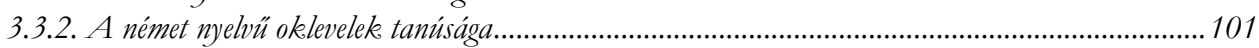

3.4. Az egyes szerkezettípusok gyakoriságának időbeli változása ..............................105

3.5. Az egyes szerkezettípusok társadalmi megoszlása ...............................................108

3.6. A név oklevélbeli helyzetének hatása a személyjelölő szerkezet

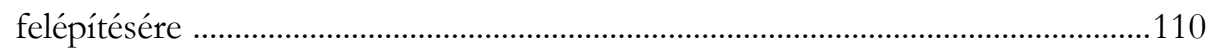

3.7. A közszói eredetű megkülönböztető névelemek és családnevek elemzése .......111

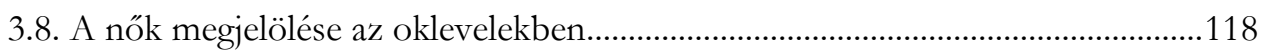

3.8.1. A latin nyelvü oklevelek tanúsága ............................................................................................. 118

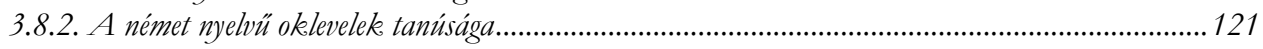

\section{SZEMÉLYNEVEK FORDÍTÁSA KÉSEI ÓMAGYAR KORI}

OKLEVELEKBEN

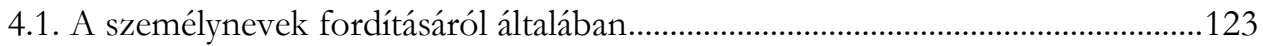

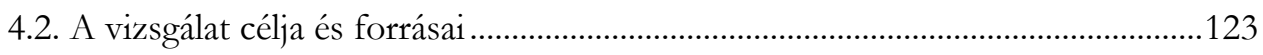

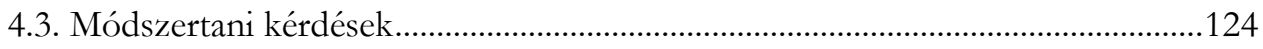

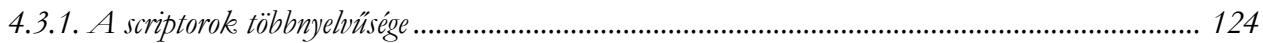

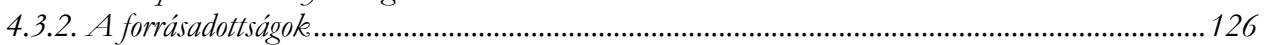

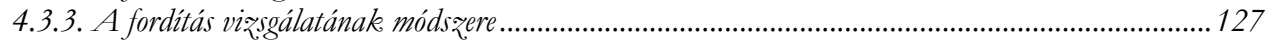

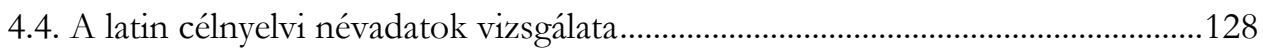

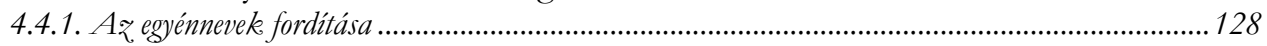

4.4.2. Megkë̈lönböztetó névelemek és családnevek fordítása ................................................................129 
4.4.2.1. Egyénnévi eredetū megkëllönbözৃtető névelemek és családnevek ...................................................130

4.4.2.2. Helynévi eredetü megkeülönböz̨tetö névelemek és családnevek ....................................................130

4.4.2.3. A közsqói eredetü többi motivációs-jelentéstani csoport..............................................................131

4.4.3. Latin célnyelvú személynévforditási stratégiák és változásuk: következtetések .............................. 134

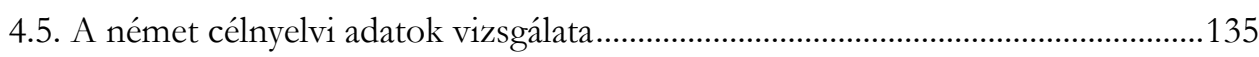

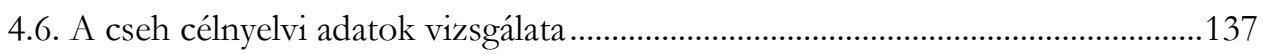

4.7. A különböző célnyelvi adatok összevetéséből adódó következtetések..............139

\section{A SZEMÉLYNEVEKET ÉRINTŐ KONTAKTUSHATÁSOK} TIPOLÓGIÁJA......................................................................................................141

5.1. A történeti névkontaktológiai vizsgálatok korlátai ..............................................141

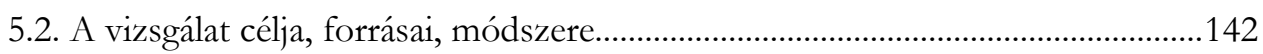

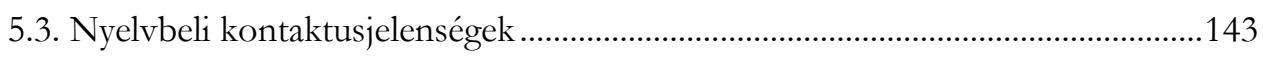

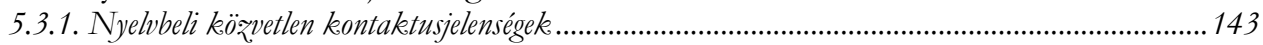

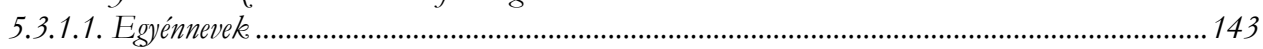

5.3.1.2. Megkë̈lönböz̨tetö névelemek és családnevek............................................................................. 145

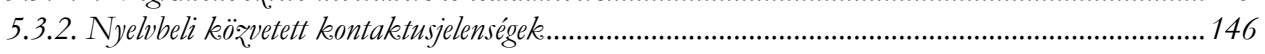

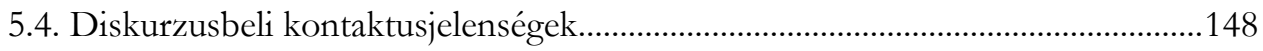

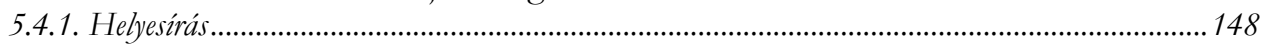

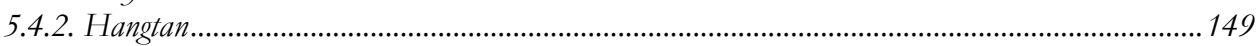

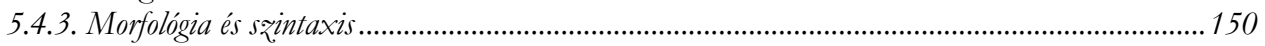

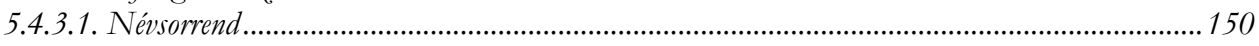

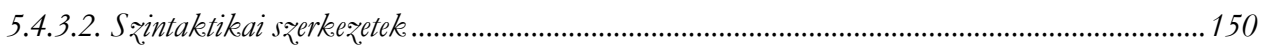

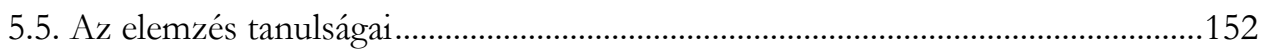

6. A VIZSGÁLATOK EREDMÉNYE ÉS HASZNOSÍTHATÓSÁGA ..............155

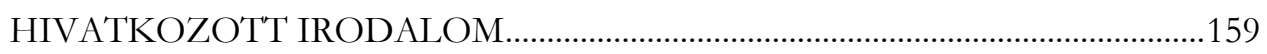

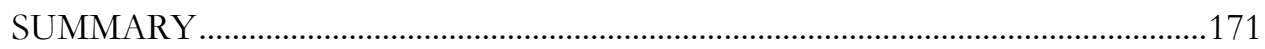





\section{TABLE OF CONTENTS}

1. THE TOPIC, SOURCES AND METHODS OF THE VOLUME ...........................13

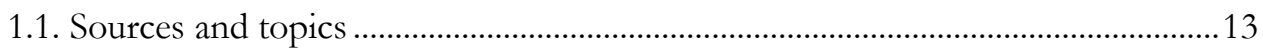

1.2. The characteristics of the compiled corpus .............................................................14

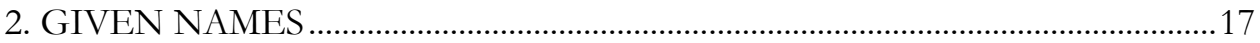

2.1. Methodological framework ...............................................................................17

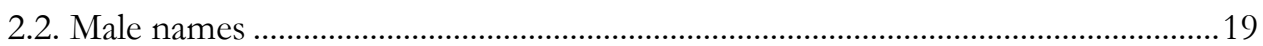

2.2.1. The most common male names among laypersons........................................................................ 19

2.2.2. The distribution of the name stock by origin in each social class.....................................................20

2.2.3. Changes in the frequency of the most popular names among landowners over time ...........................24

2.2.4. Changes in the distribution of the name stock by origin among landowners .....................................27

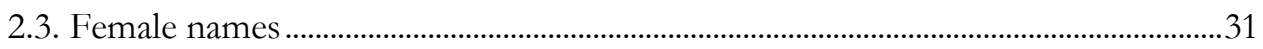

2.3.1. The most popular female names in each social class ...................................................................... 31

2.3.2. The distribution of female names by origin in each social class .....................................................33

2.3.3. Changes in the distribution of the name stock by origin among noble ladies over time ....................... 35

2.4. The variants of loan names...............................................................................................37

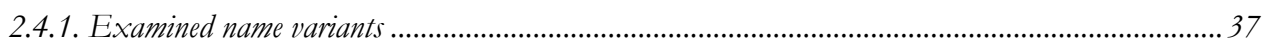

2.4.2. The difficulty of separating name variants .......................................................................................42

2.4.3. Changes in the frequency of name variants used in documents over time ........................................44

2.4.4. The social distribution of name variants used in legal documents................................................... 46

2.4.5. Connections between Latin base names and their spoken language variants: unique

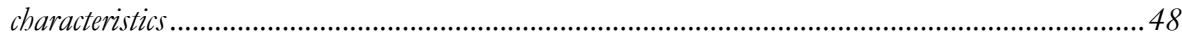

2.4.6. Using name variants in researching the jo-/ju- $>$ i- phonological change ......................................51

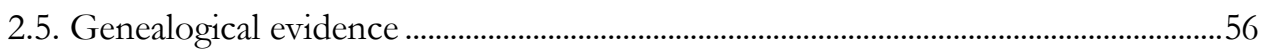

2.5.1. How genealogy can be used in historical onomastics ..................................................................56

2.5.1.1. The role of geneology in determining the origin of a name ...........................................................5 57

2.5.1.1.1. Methodological remarks on the origin of names .......................................................................57

2.5.1.1.2. The origin of the name Jolánta: genealogy in the works .......................................................59

2.5.1.2. The influence of marriages in the spread of names among nobles in mediaeval Hungary............... 64

2.5.1.3. Hereditary given names among nobles in mediaeval Hungary ......................................................67

2.5.1.4. The inheritance of names of literary origin ............................................................................ 75

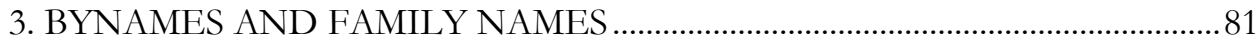

3.1. Using formal criteria in the analysis of historical family names ............................8 81

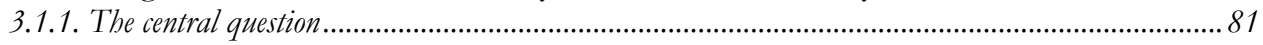


3.1.2. A comparison of name phrases from 14th-century documents and 16th-century censuses: 1 st study

3.1.3. A comparison of name phrases from 14th-century documents and the Papal tithe register

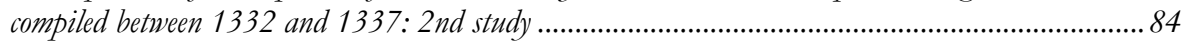

3.1.4. A comparison of name phrases from three types of 16 th-century sources .......................................... 85

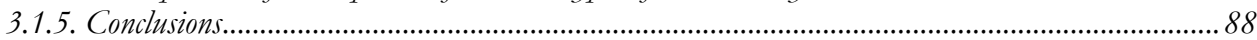

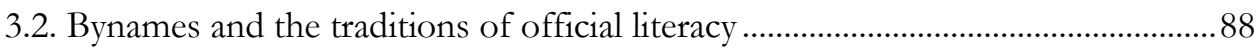

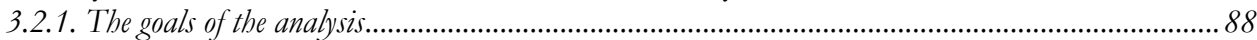

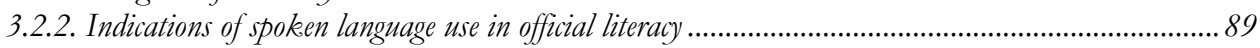

3.2.2.1. Indications of spoken language use in given names...................................................................... 90

3.2.2.2. Indications of spoken language use in bynames ........................................................................... 90

3.2.2.2.1. Name phrases containing dictus .......................................................................................... 91

3.2.2.2.2. Bynames originating from a relative's name ........................................................................92

3.2.2.2.3. Bynames of toponymic origin .................................................................................................. 94

3.2.3. Further questions regarding bynames of toponymic origins ............................................................. 94

3.2.3.1. Different bynames of toponymic origin used with a given name ......................................................94

3.2.3.2. Several bynames of toponymic origin used with a single given name ...............................................96

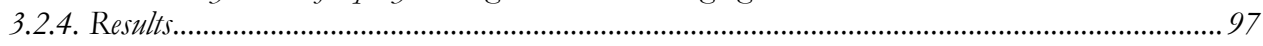

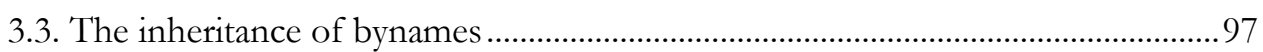

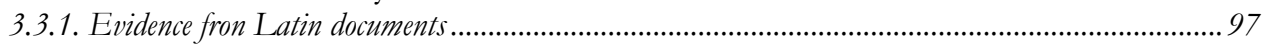

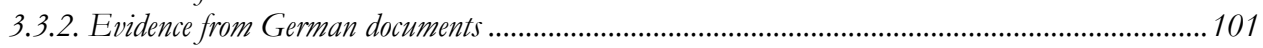

3.4. Changes in the frequency of the different types of name phrases

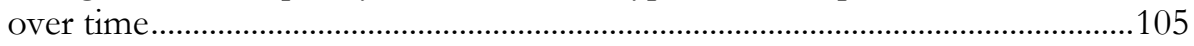

3.5. The social distribution of the different types of name phrases ...........................108

3.6. How a name's location in a document effects the structure of the name phrase

3.7. An analysis of bynames and family names originating from

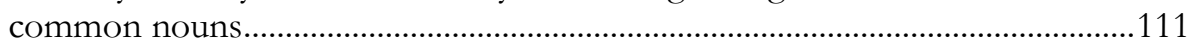

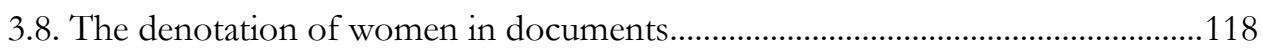

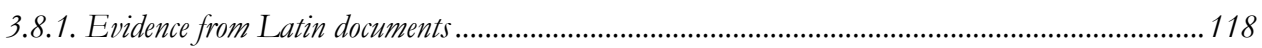

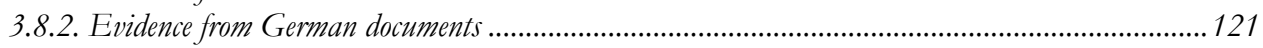

4. THE TRANSLATION OF ANTHROPONYMS IN DOCUMENTS

FROM THE LATE OLD HUNGARIAN ERA................................................... 123

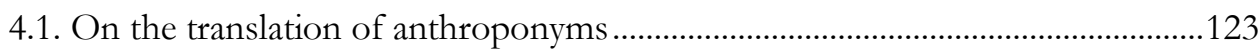

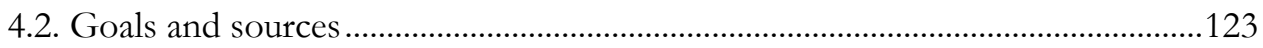

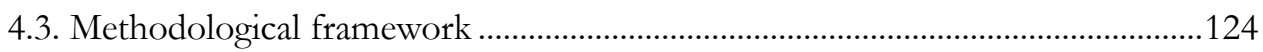

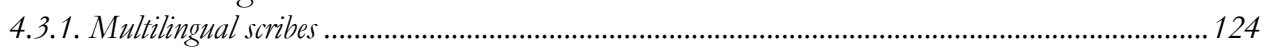

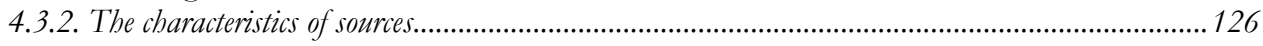

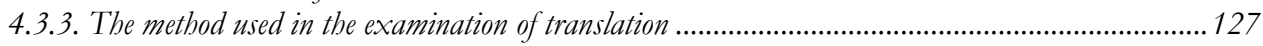


4.4. Name phrases from documents in which the target language was Latin............128

4.4.1. The translation of given names ............................................................................................ 128

4.4.2. The translation of bynames and family names ………………………………………………...129

4.4.2.1. Bynames and family names originating from anthroponyms ..................................................130

4.4.2.2. Bynames and family names of toponymic origin .....................................................................130

4.4.2.3. Other semantic groups originating from common nouns............................................................131

4.4.3. Translation strategies in Latin documents and how these changed - conclusions..............................134

4.5. Documents in which the target language was German ........................................135

4.6. Documents in which the target language was Czech..........................................137

4.7. Conclusions drawn from the analysis of data from all target languages ............139

5. A TYPOLOGY OF CONTACT PHENOMENA

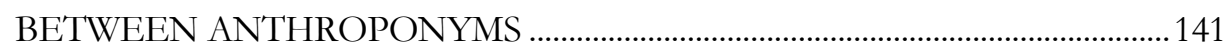

5.1. The restrictions of the historical study of contact phenomena

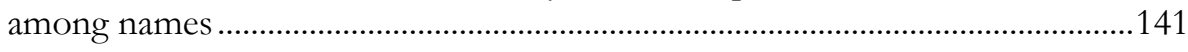

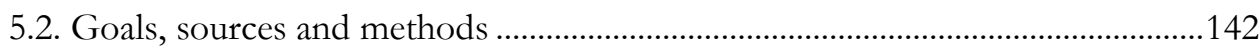

5.3. Language contact phenomena ……………………………………………......143

5.3.1. Direct language contact phenomena ……………………………...........................................143

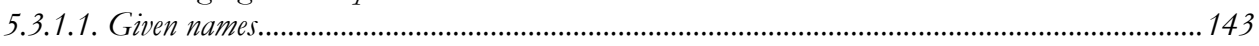

5.3.1.2. Bynames and family names............................................................................................145

5.3.2. Indirect language contact phenomena ……………………………………………………....146

5.4. Discourse contact phenomena …………………………..................................148

5.4.1. Orthography ………………………………………………………………..... 148

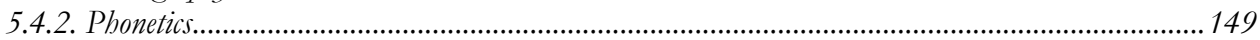

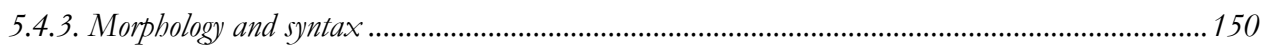

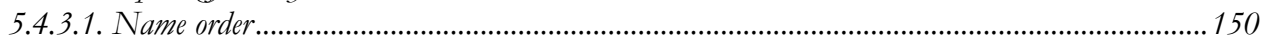

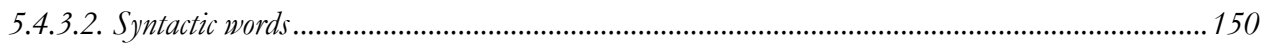

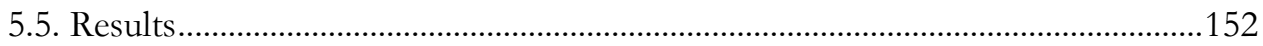

6. THE USABILITY OF THE RESULTS OF THE ANALYSIS ............................155

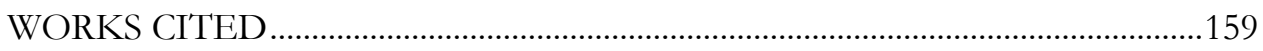

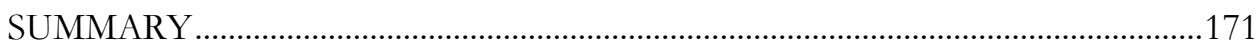





\section{A KÖTET TÉMÁJA, FORRÁSAI ÉS MÓDSZEREI}

\subsection{A kötetben feldolgozott források és témák}

A kötet mind témájában, mind a vizsgálatok alapjául szolgáló korpuszt tekintve a Személynévadás az Anjou-korban (2011b) címú monográfiám folytatásának tekinthető. E korábbi munkámban a 13-14. századi személynévadást és névhasználatot mutattam be az Anjoukori okmánytár 1301-1342 közötti időszakot lefedő első 3,5 kötetéből, egyéb okmánytárakból (HOkl., HéOkl., KárOkl.), az 1332-1337-es pápai tizedjegyzékből és kiadatlan oklevelekből gyűjtött, közel 14000 névadat alapján épített korpuszt elemezve (vö. SLíz 2011a, 2011b). Az azóta eltelt időszakban folytattam az Anjoukori okmánytárban található oklevelek feldolgozását, adatbázisomat az 1342-1359 közötti, az okmánytár utolsó, 7. kötetével záruló időszakban feljegyzett nevekkel, valamint több, az adott korszakban született mezôvárosi oklevéllel kiegészítve. Ennek a gyújtésnek a szótárrá rendezett anyaga az Anjou-kori személynévtár folytatásaként megjelenés előtt áll (SLíz 2017).

A következőkben az így létrejött, 1301-1359 közötti évtizedek okleveleiből nyert adatokat egyesítő korpusz alapján mutatom be az ómagyar kor, elsősorban a 13-16. század magyarországi személynévállományát és névadási, névhasználati szokásait (2. fejezet). Az utóbbi téma feldolgozásába, a névöröklés szerteágazó kérdéskörének körüljárásához emellett - egyszerre kiegészítő korpuszként és szakirodalomként ENGEL PÁL középkori genealógiáját (2003) is bevontam.

Az egyénnevek mellett ismét foglalkozom a családnevek kialakulását érintő kérdésekkel is (3. fejezet). Ennek során az éló névhasználat nyomait kutatom, kiemelt figyelmet fordítva ugyanakkor a kor oklevélírásának a személyjelölésben követett normáira, illetve azok időbeli változására is. Meggyőződésem ugyanis, hogy ezek minél alaposabb feltárása közelebb vihet bennünket a családnévtörténet első korszakának mélyebb megismeréséhez. A latin oklevelekből nyerhető információkat német és cseh nyelvű oklevelek felhasználásával egészítem ki; meglátásom szerint ugyanis a különböző nyelvú személyjelölő szerkezetek összevetése több témakörben is előrébb viheti a személynévtörténeti vizsgálatokat. Így a német nyelvű oklevelek tanúságát a családnevek kialakulásának korával kapcsolatban is érdemes figyelembe vennünk.

Emellett a két említett vulgáris nyelv bevonása egyéb fontos, az ómagyar kori személynevek kapcsán eddig még részletesen nem vizsgált kérdéskörök körüljárásában is nagy hasznunkra lehet. Ezek egyike a személynevek fordítása; nem szabad ugyanis elfelednünk, hogy egy korabeli vulgáris nyelv neveinek más vulgáris, illetve 
latin nyelvű oklevelekbe való bekerülése valójában névfordítással történt. A mai személynévfordítási gyakorlattal több munka is foglalkozik (ezekről bővebben 1. az adott fejezetben). Köztudomású azonban, hogy az egy-egy nyelvben alkalmazott fordítási stratégiák időben változhatnak, így egy, a kései ómagyar korra vonatkozó vizsgálat számos tanulsággal szolgálhat. Emellett természetesen nyelvenként is eltérhet a fordítás gyakorlata, amint azt napjainkban is tapasztaljuk; ezért a három vizsgált nyelv (a latin, a német és a cseh) kései ómagyar kori személynévfordítási gyakorlatának az összevetése szintén releváns eredményekkel gazdagíthatja nemcsak a névtörténeti, hanem a fordítástudományi kutatásokat is (vö. 4. fejezet).

A másik, mind ez idáig szintén kevés figyelemben részesüló témakör a személynevekben felfedezhető kontaktusjelenségek vizsgálata (1. 5. fejezet). Ez természetesen szorosan összefügg az előző kérdéskörrel, hiszen mindkettőnek a létjogosultságát, illetve történeti-művelődéstörténeti hátterét a korabeli Magyarország soknemzetiségú, illetve scriptorainak két- vagy többnyelvú volta szolgáltatja. Ennélfogva a korábban már felhasznált német és cseh nyelvű oklevelek e téren is megfelelő kiegészítő forrásokként alkalmazhatók.

E fejezet zárásaként röviden a terminológiai kérdésekre is érdemes kitérni. Bár munkámban többnyire a korábbi írásaimban alkalmazott terminusokat használom (bővebben 1. SLíz 2010), a korábbi névszerkezęt helyett pontosabbnak, e szerkezetek jellemzőit jobban kifejezőnek találom a TÓTH VALÉRIA (2013: 228) által bevezetett személyjelöló szerkęzet terminust, ezért a továbbiakban ezt alkalmazom. A megkïlönböztetón névelem terminust azonban - annak ellenére, hogy mint korábban jeleztem, magam sem tartom teljesen megfelelőnek (vö. SLíz 2010: 162, 166-167) - jobb híján egyelőre nem vetem el. A szakirodalomban nem terminusként korábban is megjelenő, TÓTH VALÉRIA (2016: 126, 216) által terminusként is javasolt családnévelóżmény ugyan a névfajta megnevezésére alkalmasnak látszik, egy adott névre használva azonban már problémásnak tűnik, hiszen e névfajta példányaiból nem feltétlenül vált családnév.

\subsection{Az összesített korpusz jellemzői}

Korábbi, 1301-1342 közötti adatbázisom világi és egyházi személyek nevét egyaránt tartalmazta. Ezzel szemben a gyújtés második szakaszában, mely több mint 6600 újabb névadattal szolgált, kizárólag világiak neveivel gazdagodott az adatbázis. Ez csaknem 2000-rel kevesebb, mint a világiaknak az első szakaszban összegyúlt névanyaga. Az Anjoukori okmánytár 5-7. kötetei ugyanis, bár hozzávetőlegesen ugyanannyi oklevelet tartalmaznak, mint az előzők, lényegesen kisebb időszakot, a korábbi bő negyvenhez képest mindössze tizenhét évet fognak át. Ennélfogva a jelenlegi gyújtésben számos személynek nagy gyakorisággal ismétlődött a neve, ráadásul sokuk már az 1301-1342-es adatbázisban is szerepelt. A korábban kidolgozott alapelvnek megfelelően azonban egy-egy névviselőnek csak az eltérő szerkezetú 
említéseit vettem fel az adatbázisba, ezért a közel azonos oklevélmennyiségból valamivel kevesebb adat volt kinyerhető.

Az eddig elmondottak nemcsak a korpusz méretére, hanem feldolgozásának a módjára is hatással voltak. Az elsőként hangsúlyozandó következmény, hogy a gyüités második szakaszából származó új adatbázis anyagát nem lehet az előzőtől függetlenül elemezni. Nemcsak azért, mert az előző szerves folytatásaként ott veszi fel a fonalat, ahol a korábbi gyújtés letette, hanem azért is, mert az apaneves szerkezetek miatt nemcsak a vizsgált 17 évben élő, hanem a korábbi korszakokba sorolható személyek neve is jelentős számban előfordul benne. Ez pedig azt eredményezi, hogy az előző korpusz feldolgozásakor létrehozott 30 éves idősávokba besorolt adatok mennyisége - különösképpen az 1283-1312 és 1312-1342 közé eső két korszaké - nem elhanyagolható mértékben megnövekedett. Ez természetesen kihat mind az egyes nevek gyakoriságának, mind pedig a névállomány eredet szerinti megoszlásának az időbeli változását érintő vizsgálatokra. Ezért a következőkben a két adatbázist egyetlen, időben folytonos korpuszként kezelem, az újabb elemzéssel nyert eredményeket folyamatosan összevetve a korábbiakkal (vö. SLíz 2011b).

A forrásadottságokból eredő másik következmény, hogy míg a korábbi korpuszt az egy generációnak nagyjából megfelelő, 30 éves időszakokra lehetett tagolni, addig az újabb korpusz a korábbi elemzésben 0.-nak nevezett időszakból (1343-1372) mindössze az első 17 évet fedi le. Ezen az adathiányon egyrészt az Anjoukori okmánytár készülőben lévő 8-9. kötetének majdani feldolgozása (vö. TRINGLI - C. TóTH CSUKOVITS 2008), másrészt az azt követő időszakból származó, egyelőre kiadatlan oklevelekből való adatgyújtés segíthet majd. E hiányosság azonban nem akadályozza meg az összehasonlítást, hiszen e korszakból - a többihez hasonlóan, sôt többet meg is előzve - így is több ezres nagyságrendben rendelkezünk adatokkal. 



\section{EGYÉNNEVEK}

\subsection{Módszertani bevezetés}

E fejezet első részében (2.2.-2.4. fejezet) az összesített korpusz egyénnévanyaga alapján mutatom be a 13-14. század névadásának jellemzőit. Az adatok feldolgozása, a néveredet megállapítása, a névviselők azonosítása, 30 éves időszakokba sorolása stb. a korábbi korpusz kapcsán már bemutatott módon történt (vö. SLíz 2011b: 33-67), ezért ezek részletezésétől a továbbiakban eltekintek. Az egyénnevek állományának a bemutatásában a korábbi feldolgozás (SLíz 2011b) menetét követem: részletesen tárgyalom a férfi- és női nevek állományának társadalmi megoszlását és időbeli változását, a névanyag területi megoszlására azonban a korábbi monográfiámmal ellentétben most nem térek ki. Ennek legfőbb oka, hogy korábbi eredményeim szerint nem mutatható ki jelentős területi eltérés az egyes vidékek egyénnévanyaga, a nevek gyakorisága között. Hangsúlyozandó azonban, hogy e megállapítás kizárólag a birtokos rétegre vonatkoztatható, hiszen sem a korábbi, sem az újabb adatbázis nem tartalmaz annyi adatot a többi rétegre vonatkozólag, hogy azok alapján a területi megoszlást lehessen vizsgálni. Ez nem csupán azt jelenti, hogy a többi rétegből kevés az adat, hanem azt is, hogy meglehetôsen esetleges és egyenetlen ezek területi megoszlása. Ez pedig teljességgel lehetetlenné teszi az ilyen jellegű vizsgálatot, különösen ha figyelembe vesszük a polgárság városonként változó és a jobbágyok vidékenként eltérő etnikai összetételét, mely bizonyára befolyással lehetett nemcsak az egyes nevek gyakoriságára, hanem a névanyag eredet szerinti összetételére is.

Abban, hogy a birtokosok immár több mint 11500 adatot számláló névállományában miért nem lehet szignifikáns területi különbségeket felfedezni, véleményem szerint több tényező is szerepet játszik. Elsőként említendő az a tény, hogy számos jelentős nemesi család eleve nem köthető egy adott vidékhez, hiszen több, egymástól gyakran távol lévő megyében is voltak birtokaik. Ráadásul a jobbágyoknál általában véve mobilisabbak lévén az udvar, az uralkodócsalád vagy a távolabbi vidékek, más országok névadási szokásai is hathattak rájuk.

Nem hagyható figyelmen kívül az sem, hogy számos nagy hatalmú család ősei más országból települtek be, nemcsak a korábbi időkben, hanem a 14-15. században is. A 14. században a legjelentősebb közülük a Károly Róberttel Nápolyból érkező, francia gyökerű Drugeth család, de például a német nyelvterületről érkező Tellesbrunniak is gyakran felbukkannak az oklevelekben, akárcsak a délszláv vagy cseh, lengyel származású előkelők. E családok névadási szokásaira egyrészt még egy ideig hatással lehetett korábbi otthonuk névállománya, másrészt öröklött 
magyarországi birtokaik kezdetben nem lévén még annyira sem köthetôk egy adott régióhoz, mint a magyar eredetú vagy korábban elmagyarosodott, régebbi nemesi családok.

Más vidékek, országok névanyagát, szokásait közvetíthették a messzire, több esetben akár külföldre nyúló házassági-rokoni kapcsolatok is. A Nagymartoni család például több osztrák-német nemesi családdal (Haschendorfi, Pottendorfi, Puchaim) is rokonságban állt, Szécsényi Tamás országbíró Auschwitzi Anna lengyel hercegnőt, ifjabb Garai Miklós nádor Lázár szerb fejedelem lányát, az öccse, Garai János Hedvig mazóviai hercegnőt vette feleségül, a Frangepánok pedig a magyar mellett délszláv, itáliai és német rokonsággal is rendelkeztek (vö. ENGEL 2003). A nemesi családok közötti vérségi kapcsolatok különösen fontos szerepet töltöttek be egy-egy család névadási stratégiáiban és szokásaiban. Az egyénneveket tárgyaló 2. fejezet második részében (2.5. fejezet) ezért ENGEL PÁL már említett genealógiája alapján (2003) azt igyekszem feltárni, hogyan befolyásolták a nemesség névadási szokásait a nemzetségi és családi hagyományok, valamint a családok közötti kapcsolatok.

A fentebb felsorolt tényezők (több vidékre kiterjedő birtokállomány, az udvarban és az utazások révén szerzett tapasztalatok [beleértve a névdivatot is], családi és nemzetségi hagyományok) meggyőződésem szerint erőteljesebben befolyásolhatták a nemesség névválasztását, mint egy adott vidék névadási szokásai. Ezért egy, a korábbihoz hasonló területi vizsgálat meggyőződésem szerint ugyanarra az eredményre, vagyis az egyes régiók névállománya közötti nagyfokú hasonlóságra vezetne.

A továbbiakban tehát az egyénnevek kapcsán először a férfiak, majd a nôk névállományát tekintem át, a következő sorrendben: a teljes korpusz leggyakoribb nevei társadalmi rétegenként; a névállomány eredet szerinti megoszlása az egyes rétegekben; a leggyakoribb nevek népszerűségének időbeli változása a birtokosok körében; és végül a nevek eredet szerinti megoszlásának időbeli változása. Az utóbbi két témát a korábbi feldolgozáshoz hasonlóan kényszerúségből szúkítettem a birtokos rétegre, a többi rétegből ugyanis nem áll rendelkezésemre elegendő adat az idôbeli változások megbízható vizsgálatára.

Ezt követően az egyházi nevek magyar és más vulgáris nyelvú változatait tekintem át. Ennek során nemcsak a személyneves korpuszt, hanem a forrásul szolgáló latin oklevelekben fellelhető helyneveket, pontosabban a bennük szereplő egyénnévváltozatokat is számításba veszem. Az áttekintésben szót ejtek a névváltozatok oklevélbeli arányának társadalmi megoszlásáról és időbeli változásáról, az egyes nevek esetében megfigyelhető sajátosságokról, valamint a $j u-/ j o->i$ - változás kapcsán egyes változatok nyelvtörténeti hasznosíthatóságát is bemutatom. 


\subsection{Férfinevek}

\subsubsection{A leggyakoribb férfinevek a világiak körében}

Az 1. táblázat azokat a férfineveket tünteti fel, amelyek a legnagyobb arányban vannak jelen az összesített korpuszban. Az egyes rétegek eltérő adatmennyisége miatt a százalékos adatok mögötti darabszámok nagyságrendi különbségeket mutatnak, így jelentôs torzítással kell számolnunk. (A táblázatba csak az ötnél több viselôvel rendelkező nevek kerültek be.) Ennek ellenére annyit megállapíthatunk, hogy bár az adatok mennyisége csaknem megkétszereződött, nem tapasztalható nagyobb eltérés a korábbi gyüjtésből származó eredményekhez képest (vö. SLÍz 2011b: 68-69). A legjelentősebb különbségnek az látszik, hogy míg korábban a János csak a nemesek és a jobbágyok körében állt az első helyen, addig az összesített korpuszban már minden rétegben e név vezeti a listát, ráadásul egyedül vagy a Miklós-sal együtt kiemelkedő megterheltséget mutatva. Ha a birtokosok eredményeire koncentrálunk, azt látjuk, hogy az újabb adatok nemigen változtattak az egyes nevek megterheltségén, kivéve a János és a Miklós arányának kb. 1\%-os növekedését. Ez arra enged következtetni, hogy e két név népszerūsége, mely az Árpád-kor utolsó századától fokozatosan növekedni látszik az eddigi adatok szerint (vö. SLÍZ 2011b: 70), a 14. század közepén tovább fokozódott. E feltevést az egyes nevek népszerűségének időbeli változását bemutató vizsgálat igazolhatja; előbb azonban még érdemes áttekinteni a névállomány eredet szerinti megoszlását is.

\begin{tabular}{|c|c|c|c|c|c|c|}
\hline \multirow{2}{*}{ Pozíció } & \multicolumn{3}{|c|}{ Birtokos } & \multicolumn{3}{|c|}{ Polgár } \\
\hline & név & $\mathrm{db}$ & $\%$ & név & $\mathrm{db}$ & $\%$ \\
\hline 1. & János & 1329 & 11,48 & János, Mikelós & 50 & 12,59 \\
\hline 2. & Miklós & 1182 & 10,21 & Péter & 26 & 6,55 \\
\hline 3. & Péter & 864 & 7,46 & István & 20 & 5,04 \\
\hline 4. & István & 690 & 5,96 & Mibály & 19 & 4,79 \\
\hline 5. & Lás‡ló & 531 & 4,59 & Pál & 16 & 4,03 \\
\hline 6. & Pál & 500 & 4,32 & Jakab & 15 & 3,78 \\
\hline 7. & Mihály & 443 & 3,83 & András & 10 & 2,52 \\
\hline 8. & András & 386 & 3,33 & Henrik. & 9 & 2,27 \\
\hline 9. & Jakab & 378 & 3,27 & György & 8 & 2,02 \\
\hline 10. & Tamás & 339 & 2,93 & Tamás & 7 & 1,76 \\
\hline 11. & Domokos & 267 & 2,31 & Domokos, Kunch & 6 & 1,51 \\
\hline 12. & Lórinc & 241 & 2,08 & & & \\
\hline 13. & György & 218 & 1,88 & & & \\
\hline 14. & Gergely & 204 & 1,76 & & & \\
\hline 15. & Benedek. & 159 & 1,37 & & & \\
\hline $\begin{array}{c}\text { Összes } \\
\text { név }\end{array}$ & & 11577 & 100,00 & & 397 & 100,00 \\
\hline
\end{tabular}




\begin{tabular}{|c|c|c|c|c|c|c|c|c|c|}
\hline \multirow{2}{*}{ Pozíció } & \multicolumn{3}{|c|}{ Mezővárosi polgár } & \multicolumn{3}{|c|}{ Jobbágy } & \multicolumn{3}{|c|}{ Egyéb } \\
\hline & név & $\mathrm{db}$ & $\%$ & név & $\mathrm{db}$ & $\%$ & név & $\mathrm{db}$ & $\%$ \\
\hline 1. & János & 43 & 10,75 & János & 74 & 12,89 & János & 72 & 9,02 \\
\hline 2. & Miklós & 32 & 8,00 & Péter & 55 & 9,58 & Miklós & 70 & 8,77 \\
\hline 3. & Péter & 29 & 7,25 & István & 39 & 6,79 & Péter & 69 & 8,65 \\
\hline 4. & István, Pál & 21 & 5,25 & Pál & 38 & 6,62 & Pál & 47 & 5,89 \\
\hline 5. & $\begin{array}{l}\text { Mihály, } \\
\text { Tamás }\end{array}$ & 16 & 4,00 & Miklós & 28 & 4,88 & István & 41 & 5,14 \\
\hline 6. & Jakab & 15 & 3,75 & Mibály & 25 & 4,36 & Benedek & 30 & 3,76 \\
\hline 7. & András, & 13 & 3,25 & György & 22 & 3,83 & $\begin{array}{l}\text { Lásźló, } \\
\text { Mibály }\end{array}$ & 27 & 3,38 \\
\hline 8. & László & 12 & 3,00 & András & 19 & 3,31 & András & 22 & 2,76 \\
\hline 9. & Domokos & 11 & 2,75 & Benedek. & 17 & 2,96 & $\begin{array}{l}\text { Jakab, } \\
\text { Tamás }\end{array}$ & 18 & 2,26 \\
\hline 10. & $\begin{array}{l}\text { Demeter, } \\
\text { Imre }\end{array}$ & 9 & 2,25 & Lász̨ló & 12 & 2,09 & $\begin{array}{l}\text { Domokos, } \\
\text { György }\end{array}$ & 16 & 2,01 \\
\hline 11. & György & 7 & 1,75 & Jakab & 11 & 1,92 & Balázs & 13 & 1,63 \\
\hline 12. & $\begin{array}{l}\text { Balázs, } \\
\text { Benedek, } \\
\text { Gergely, } \\
\text { Lórinc, } \\
\text { Márton }\end{array}$ & 6 & 1,50 & Tamás & 10 & 1,74 & Lórinc & 12 & 1,50 \\
\hline 13. & & & & Domokos & 9 & 1,57 & Gergely & 11 & 1,38 \\
\hline 14. & & & & $\begin{array}{l}\text { Balázs, } \\
\text { Gergely, } \\
\text { Kelemen, } \\
\text { Lórinc, } \\
\text { Márton }\end{array}$ & 8 & 1,39 & Simon & 10 & 1,25 \\
\hline 15. & & & & $\begin{array}{l}\text { Demeter, } \\
\text { Márk }\end{array}$ & 7 & 1,22 & $\begin{array}{l}\text { Egyed, } \\
\text { Imre, } \\
\text { Máté }\end{array}$ & 9 & 1,13 \\
\hline $\begin{array}{c}\text { Összes } \\
\text { név }\end{array}$ & & 400 & 100,00 & & 574 & 100,00 & & 798 & 100,00 \\
\hline
\end{tabular}

1. táblázat: A leggyakoribb egyénnevek a világiak körében

\subsubsection{A névállomány eredet szerinti megoszlása az egyes rétegekben}

Az új gyűjtés láthatólag nem sokat változtatott a nevek eredet szerinti megoszlásán (vö. SLÍZ 2011b: 72-73). Bár az adatmennyiségek nagyságrendi eltéréseiből következő torzítás miatt az egyes rétegekre jellemző eredet szerinti megoszlás számarányainak összevetését óvatosan kell kezelnünk, az teljes biztonsággal megállapítható, hogy a jövevénynevek minden rétegben elsöprő fölényben vannak a magyar eredetűekhez képest (2. táblázat). 


\begin{tabular}{|c|c|c|c|c|c|c|c|c|c|c|}
\hline & \multicolumn{2}{|c|}{ Birtokos } & \multicolumn{2}{|c|}{ Polgár } & \multicolumn{2}{|c|}{$\begin{array}{c}\text { Mezővárosi } \\
\text { polgár }\end{array}$} & \multicolumn{2}{|c|}{ Jobbágy } & \multicolumn{2}{|c|}{ Egyéb } \\
\hline & $\mathrm{db}$ & $\%$ & $\mathrm{db}$ & $\%$ & $\mathrm{db}$ & $\%$ & $\mathrm{db}$ & $\%$ & $\mathrm{db}$ & $\%$ \\
\hline Magyar & 393 & 3,39 & 12 & 3,02 & 13 & 3,25 & 32 & 5,57 & 37 & 4,64 \\
\hline Jövevény & 10872 & 93,91 & 382 & 96,22 & 373 & 93,25 & 516 & 89,90 & 742 & 92,98 \\
\hline Bizonytalan & 193 & 1,67 & 1 & 0,25 & 8 & 2,00 & 16 & 2,79 & 10 & 1,25 \\
\hline Ismeretlen & 119 & 1,03 & 2 & 0,50 & 6 & 1,50 & 10 & 1,74 & 9 & 1,13 \\
\hline Összesen & 11577 & 100,00 & 397 & 100,00 & 400 & 100,00 & 574 & 100,00 & 798 & 100,00 \\
\hline
\end{tabular}

2. táblázat: A világiak neveinek megoszlása eredet szerint

A 3. táblázat megerősíti a korábbi megállapítást, amely szerint ezt az arányt a görög-latin eredetú nevek nagy népszerúsége okozza. Az új gyűjtés legnagyobb változást hozó eredménye, hogy a polgároknál immár több mint 5\%-kal magasabb e csoport aránya a korábban látotthoz képest, de még így is több mint 14\%-kal alacsonyabb, mint a sorrendben következő mezővárosi lakosság körében. Ez azért is feltűnő, mert a többi rétegben hozzávetőlegesen azonos e névcsoport aránya. Az eltérés oka láthatólag a német és a francia eredetű neveknek a többi rétegéhez képest magasabb aránya. Ez alátámasztja azt a feltevést, hogy a német és vallon származású városi lakosság miatt a polgárság névanyaga erôsebben eltérhetett a többi rétegétől, még akkor is, ha az ô körükben is az Európa-szerte elterjedt görög-latin eredetű nevek lehettek fölényben. Egy célzott, kifejezetten a városokra koncentráló gyüjtés feltehetőleg a német és a francia eredetú nevek jóval magasabb arányát mutatná ki e rétegben.

A szláv eredetű nevek aránya ezzel szemben a polgárság körében a legalacsonyabb. Ez egyrészt annak tudható be, hogy a szláv etnikumú vagy származású lakosság nem annyira a kutatásban érintett egyes városokban, mint inkább a többi rétegben volt jelen. A nemességben a többi réteghez képest némileg magasabb arányuk részben a szláv eredetű nemzetségekkel, családokkal magyarázható. Másrészt a legnagyobb megterheltségű szláv eredetű név, a László a nemesek körében volt a legnépszerübb, míg a polgároknál be sem került a leggyakoribbak közé. Hogy egyetlen név népszerúsége mennyire meg tudja növelni egy eredet szerinti csoport arányát, azt a László remekül példázza: a korpuszbeli birtokos névállomány 4,59\%-át teszi ki (vö. 1. táblázat), így az érintett szláv eredetű neveket viselők 63\%-át Lászlónak hívták.

Az újabb gyűjtés minden eredet szerinti csoportban számos, korábban nem szereplő névpéldánnyal gazdagította a korpuszt. A magyar eredetűek között ilyen például a Balog (1347: Bolugh, AO. 5: 26), Csemete (1354: Chemete, AO. 6: 163), Jobbágy (1352: Jobagy, AO. 5: 538) vagy a Jóka (1348: Jouka, AO. 5: 250). A legmegterheltebb magyar eredetű nevek száma is újabb adatokkal gazdagodott, így jelenlegi gyakorisági listájuk a következô: Farkas (36); Mag (15); Bors (13); Bodor (12); Finta (10); Szőkee (8); Bakó, Karácsony (7); Apor, Kakas, Uracs (6); Dobó (5); Apa, Bánk, Erdö, Kónya, Szovárd (4). 
A Farkas kiugró népszerűsége nem véletlen: már az Árpád-korban is a legnépszerúbb magyar eredetú név volt (vö. SLíz 2011b: 70). E nevet a középkorban Szent Wolfgang nevével azonosították (vö. pl. NYíRI 1963: 82, FEKETE 2007³. Farkas), a szent kultusza azonban nagyobb mértékben csak a késő középkorban bontakozott ki (BÁLINT 1977. 2: 458), ezért a Farkas népszerűsége inkább óvónévi „múltjából”, nem pedig egyházi vonatkozásából fakadhat. Ezt támasztja alá véleményem szerint az is, hogy a korpuszban egyetlen Wolfgang sem fordul elő. Ugyanakkor az, hogy a magyar eredetű nevek közül a Farkas szinte egyedüliként élt tovább a későbbi korokban is, már minden bizonnyal az említett névazonositásnak köszönhető.

\begin{tabular}{|c|c|c|c|c|c|c|c|c|c|c|}
\hline & \multicolumn{2}{|c|}{ Birtokos } & \multicolumn{2}{|c|}{ Polgár } & \multicolumn{2}{|c|}{$\begin{array}{l}\text { Mezővárosi } \\
\text { polgár }\end{array}$} & \multicolumn{2}{|c|}{ Jobbágy } & \multicolumn{2}{|c|}{ Egyéb } \\
\hline & $\mathrm{db}$ & $\%$ & $\mathrm{db}$ & $\%$ & $\mathrm{db}$ & $\%$ & $\mathrm{db}$ & $\%$ & $\mathrm{db}$ & $\%$ \\
\hline Török & 134 & $\begin{array}{r}1,23 \\
(1,16)\end{array}$ & - & - & 4 & $\begin{array}{c}1,07 \\
(1,00)\end{array}$ & 2 & $\begin{array}{c}0,39 \\
(0,35)\end{array}$ & 10 & $\begin{array}{r}1,35 \\
(1,25)\end{array}$ \\
\hline Görög-latin & 9278 & $\begin{array}{c}85,34 \\
(80,14) \\
\end{array}$ & 268 & $\begin{array}{c}70,16 \\
(67,51)\end{array}$ & 317 & $\begin{array}{c}84,99 \\
(79,25)\end{array}$ & 464 & $\begin{array}{c}89,92 \\
(80,84)\end{array}$ & 629 & $\begin{array}{r}84,77 \\
(78,82) \\
\end{array}$ \\
\hline Német & 530 & $\begin{array}{c}4,87 \\
(4,58)\end{array}$ & 87 & $\begin{array}{c}22,77 \\
(21,91)\end{array}$ & 29 & $\begin{array}{c}7,77 \\
(7,25)\end{array}$ & 18 & $\begin{array}{c}3,49 \\
(3,14)\end{array}$ & 43 & $\begin{array}{r}5,80 \\
(5,39)\end{array}$ \\
\hline Szláv & 791 & $\begin{array}{l}7,28 \\
(6,83)\end{array}$ & 11 & $\begin{array}{c}2,88 \\
(2,77)\end{array}$ & 22 & $\begin{array}{c}5,90 \\
(5,50)\end{array}$ & 28 & $\begin{array}{c}5,43 \\
(4,88)\end{array}$ & 52 & $\begin{array}{r}7,01 \\
(6,52)\end{array}$ \\
\hline Francia & 72 & $\begin{array}{c}0,66 \\
(0,62)\end{array}$ & 9 & $\begin{array}{c}2,36 \\
(2,27)\end{array}$ & 1 & $\begin{array}{c}0,27 \\
(0,25)\end{array}$ & - & - & 3 & $\begin{array}{c}0,40 \\
(0,38)\end{array}$ \\
\hline Bizonytalan & 51 & $\begin{array}{c}0,47 \\
(0,44) \\
\end{array}$ & 7 & $\begin{array}{c}1,83 \\
(1,76) \\
\end{array}$ & - & - & 3 & $\begin{array}{c}0,58 \\
(0,52) \\
\end{array}$ & 4 & $\begin{array}{c}0,54 \\
(0,50)\end{array}$ \\
\hline Ismeretlen & 16 & $\begin{array}{c}0,15 \\
(0,14)\end{array}$ & - & - & - & - & 1 & $\begin{array}{c}0,19 \\
(0,17)\end{array}$ & 1 & $\begin{array}{c}0,13 \\
(0,13)\end{array}$ \\
\hline Összesen & 10872 & 100,00 & 382 & 100,00 & 373 & 100,00 & 516 & 100,00 & 742 & 100,00 \\
\hline
\end{tabular}

3. táblázat: A jövevénynevek megoszlása eredet szerint a világiak körében ${ }^{1}$

A török eredetű névállományból olyan példányok bukkantak elő az új gyújtésnek köszönhetően, mint a Balyar (1348, AO. 4: 466) Bolyar (1348, AO. 5: 182) (vö. BASKI 2007: 248. Baliar), Baykos (1352, AO. 5: 572, vö. OnomTurc. 108. Baykuss), Bezther (1358, AO. 7: 238, vö. BASKI 2007: 253. Bösqtör), Torda (1355, AO. 6: 344, vö. FNESz. ${ }^{4}$ Torda) és Wrkun (1357, AO. 6: 604, vö. MUnk. Örkény) stb. ${ }^{2}$ A gyakoribb

${ }^{1}$ A \%-os fejlécű oszlopokban az első számok az egyes kategóriáknak az adott rétegben a jövevényneveken belüli, míg a zárójelbe tett számok e réteg teljes névállományához viszonyított arányát mutatják.

${ }^{2}$ Számos török eredetű név etimológiájának a feltárásáért Baski Imrének tartozom köszönettel. 
török eredetű nevek a következők: Gyula (26); Aba (13); Itemer (10); Bodony (8); Ákos (7); Csaba (5); Becse, Berend, Bökény, Kustán (4); Kölcse, Turul, Zoltán (3).

A német eredetű nevek közül az előző korpuszhoz képest új elemként jelentkezik például a Dragnyyn (1355, AO. 6: 399, vö. FÖRSTEMANN 1900/19662: 1462. Drabwin), a Gerlach (1358: Garlah, AO. 7: 226), a Helmygh (1354, AO. 6: 220, vö. FÖRSTEMANN 1900/19662: 810. Helmiger, Helmichis), a Ledeger (1338/1340/1345, AO. 4: 535, vö. FÖRSTEMANN 1900/19662: 999. Leidiger), a Thyddo (1345, AO. 4: 546, vö. FÖRSTEMANN 1900/19662: 1411. Tido, Titdo) és a Wlful (1350, AO. 5: 369, vö. FÖrSTEMANN 1900/19662: 1661. Wolfold $)$. A leggyakoribb német eredetú nevek listáján több, a magyar eredetúeknél nagyobb megterheltségúvel is találkozunk: Henrik (37); Konrád (30); Albert (29); Detre (26); Rénold (18); Lampert (17); Herbord (16); Arnold, Frigyes, Tibald (15); Hermann (14); Leonárd (11); Heym, Lipót (10); Aladár, Lothárd, Vilmos (9); Gothárd, Heydrik, Markalf (7); Hont, Jenslin, Panyit, Walter (6); Rikalf, Rudolf (4).

A szláv eredetű nevek között is számos új elem tűnt fel: Bodolou (1349, AO. 5: 301, vö. FNESz. ${ }^{4}$ Bodolo), Bogus (1348, AO. 5: 245) Bobus (1354, AO. 6: 250) (vö. FNESz. ${ }^{4}$ Hajdúbagos), Bratizlou (1350, AO. 5: 390, vö. FNESz. ${ }^{4}$ Pozsony), Damasa (1358, AO. 7: 194, vö. FNESz. ${ }^{4}$ Ipolydamásd), Dęlow (1354, AO. 6: 250), Dragizlow (1350, AO. 5: 375), Dragsa (1350, AO. 5: 389), Goztolya (1359, AO. 7: 616, vö. FNESz. ${ }^{4}$ Gosztola) stb. ${ }^{3}$ A martirológiumba való bekerülése miatt kiemelkedő gyakoriságú Lász̧ló-tól eltekintve a gyakoribb szláv neveknek jellemzően alacsonyabb a megterheltségük a korpuszban, mint a németeknek: Bod (35); Vid (18); Ugrin (14); Ders (11); Kázmér (7); Vencel (5); Dorog, Vejteh (4); Doroszló, Merse, Pázmány, Szaniszló (3).

A francia eredetű nevek állománya nem bővült újabb névpéldánnyal az előzô gyűjtéshez képest, csupán a már meglévők száma növekedett némileg. Ez egyrészt annak tudható be, hogy egyik gyújtés sem koncentrált kifejezetten a városi lakosságra. Habár a magyarországi vallon lakosság jelentôs része a 14. századra már elpusztult a tatárjárás következtében, illetve asszimilálódott, egyes városok, különösen Esztergom és Székesfehérvár névállományából bizonyára több francia eredetû név lenne még kinyerhető ebből az időszakból is. A francia eredetű nevek másik fő forrása a középkori Magyarországon a betelepülő népesség mellett a lovagi irodalom volt. Ebből azonban viszonylag kevés név került át a névkincsbe, s ezek már a 13. század óta jelen voltak a hazai névadásban, így már az előző korpusz is tartalmazta óket. Mint a következő gyakorisági listából kitűnik, a francia eredetű nevek között az irodalmi eredetúek voltak a népszerúbbek: Roland (46); Olivér (19); Gilét (5); Rubin (4); Gekmen, Godin (2), valamint a Johannes vallon változata, a Gyán (2). Ennek az irodalom teremtette divat mellett az a magyarázata, hogy a korpusz túlnyomórészt nemesek

${ }^{3}$ Egyes szláv eredetű nevek etimológiájának feltárásáért Bauko Jánosnak tartozom köszönettel. 
nevét tartalmazza, s az irodalmi eredetú nevek inkább a nemességre jellemzők, míg a többi a korpuszban alulreprezentált polgárságra.

A vulgáris nyelvekből eredő névállományt áttekintve jól érzékelhető ezek jóval kisebb népszerűsége a leggyakoribb görög-latin eredetű neveknek az 1. táblázatban látott magas megterheltségéhez képest. A görög-latin kategórián belül a leggyakoribb nevek többsége újszövetségi (vagy az Ó- és Újszövetségben egyaránt megtalálható), illetve martirológiumi név. Az ószövetségi nevekből eleve kevesebb volt használatban, és a megterheltségük is jóval alacsonyabb volt, mint azt a következő gyakorisági lista is tükrözi. ${ }^{4}$ A legnépszerúbb közülük kétségkívül az Illés (49), az Ábrahám (45) és a Salamon (44) volt; a többi név jócskán leszakadva követi őket: Mózes (22); József (19); Dávid (15); Iz̧ák (11); Ádám (7); Jób és Saul (6); Dániel és Sámson (5); Absolon, Lázár és Sámuel (4); Ábel (2). Megjelenik ezenkívül az anyagban az Izrael (1) egy soproni, majd pozsonyi zsidó neveként (a két adat ugyanarra a személyre vonatkozik: 1353; AO. 6: 45, 6: 84). A főangyalok közül Mihály neve, mint láttuk, a legnépszerúbbek egyike volt, Gábriel és Rafael neve viszont ritkán fordult elő (12, ill. 10 adat), ahogy a korabeli vallásosságban és ennek nyomán a képzőművészetben is háttérbe szorultak Mihály arkangyal mögött (vö. MKL.).

A továbbiakban a birtokosok névállományának időbeli változását áttekintve pontosabb képet alkothatunk a különböző eredetű nevek csoportjai közötti eltérésnek a tényleges mértékéről, illetve 13-14. századi alakulásáról.

\subsubsection{A leggyakoribb nevek népszerüségének időbeli változása a birtokosok körében}

A 4. táblázat alapján világosan kirajzolódik elôttünk a névanyag homogénebbé válásának a magyar személynévtörténeti kutatásokban már régen felismert folyamata. A korábbi három mellé a legújabb, 1342 utáni korszakot is beillesztve jól látszik a lista élén álló nevek (János, Miklós) megterheltségének folyamatos és rohamosnak mondható növekedése, valamint egyes nevek kedveltségének enyhébb mértékủ fokozódása (pl. István, Jakab, Mibály). Egyes nevek megterheltsége ezzel szemben nem változott jelentősebb mértékben (pl. András). Feltűnő ugyanakkor, hogy néhány név, amely a 13. század második felében még felkerült a 15-ös lista aljára, később már kiszorult onnan (pl. Detre, Farkas, Lukács, Márk, Márton, Simon). Ennek egyrészt saját népszerűségük enyhe csökkenése, másrészt az élen álló néhány név megterheltségének mindössze egy évszázad alatt végbemenő megugrása, a „középmezónytől" való elszakadása az oka.

${ }^{4}$ A zárójelben darabszámok találhatók, a nevek alacsony megterheltsége miatt ugyanis nem volt értelme százalékos arányokat számolni. 


\begin{tabular}{|c|c|c|c|c|c|c|}
\hline \multirow{2}{*}{ Pozíció } & \multicolumn{3}{|c|}{ 3. korszak (1253-1282) } & \multicolumn{3}{|c|}{ 2. korszak (1283-1312) } \\
\hline & név & $\mathrm{db}$ & $\%$ & név & $\mathrm{db}$ & $\%$ \\
\hline 1. & János & 47 & 5,63 & Miklós & 265 & 8,51 \\
\hline 2. & Miklós & 43 & 5,15 & János & 256 & 8,22 \\
\hline 3. & Péter & 37 & 4,43 & Péter & 203 & 6,52 \\
\hline 4. & Pál & 36 & 4,31 & István & 146 & 4,69 \\
\hline 5. & István & 35 & 4,19 & Pál & 140 & 4,49 \\
\hline 6. & Jakab & 24 & 2,87 & Mibály & 112 & 3,60 \\
\hline 7. & András & 19 & 2,28 & Tamás & 101 & 3,24 \\
\hline 8. & Dénes & 18 & 2,16 & László & 96 & 3,08 \\
\hline 9. & Simon & 15 & 1,80 & Jakab & 94 & 3,02 \\
\hline 10. & $\begin{array}{l}\text { Benedek, Gergely, György, Lász̧ló, } \\
\text { Lörinc }\end{array}$ & 14 & 1,68 & András & 88 & 2,83 \\
\hline 11. & Sándor & 13 & 1,56 & Lórinc & 69 & 2,22 \\
\hline 12. & Márton, Tamás & 12 & 1,44 & Domokos & 65 & 2,09 \\
\hline 13. & Mihály & 11 & 1,32 & Gergely & 64 & 2,05 \\
\hline 14. & Domokos & 9 & 1,08 & Benedek & 59 & 1,89 \\
\hline 15. & Detre, Farkas, Lukács, Márk & 7 & 0,84 & Márton & 40 & 1,28 \\
\hline $\begin{array}{c}\text { Összes } \\
\text { név }\end{array}$ & & 835 & 100,00 & & 3115 & 100,00 \\
\hline
\end{tabular}

\begin{tabular}{|c|c|c|c|c|c|c|}
\hline \multirow{2}{*}{ Pozíció } & \multicolumn{3}{|c|}{ 1. korszak (1313-1342) } & \multicolumn{3}{|c|}{ 0. korszak (1343-1359) } \\
\hline & név & $\mathrm{db}$ & $\%$ & név & $\mathrm{db}$ & $\%$ \\
\hline 1. & János & 681 & 13,33 & János & 340 & 14,16 \\
\hline 2. & Miklós & 570 & 11,16 & Miklós & 299 & 12,45 \\
\hline 3. & Péter & 422 & 8,26 & Péter & 198 & 8,25 \\
\hline 4. & István & 317 & 6,21 & István & 188 & 7,83 \\
\hline 5. & László & 246 & 4,82 & László & 174 & 7,25 \\
\hline 6. & Pál & 233 & 4,56 & Mibály & 119 & 4,96 \\
\hline 7. & Mibály & 200 & 3,92 & Jakab & 98 & 4,08 \\
\hline 8. & András & 197 & 3,86 & Pál & 85 & 3,54 \\
\hline 9. & Jakab & 160 & 3,13 & András & 80 & 3,33 \\
\hline 10. & Tamás & 155 & 3,04 & György & 74 & 3,08 \\
\hline 11. & Domokos & 138 & 2,70 & Tamás & 71 & 2,96 \\
\hline 12. & Lörinc & 110 & 2,15 & Domokos & 55 & 2,29 \\
\hline 13. & György & 90 & 1,76 & Lórinc & 48 & 2,00 \\
\hline 14. & Gergely & 82 & 1,61 & Gergely & 44 & 1,83 \\
\hline 15. & Demeter & 67 & 1,31 & Benedek & 38 & 1,58 \\
\hline $\begin{array}{c}\text { Összes } \\
\text { név }\end{array}$ & & 5107 & 100,00 & & 2401 & 100,00 \\
\hline
\end{tabular}

4. táblázat: A egyes korszakok leggyakoribb nevei a világi birtokosok körében 


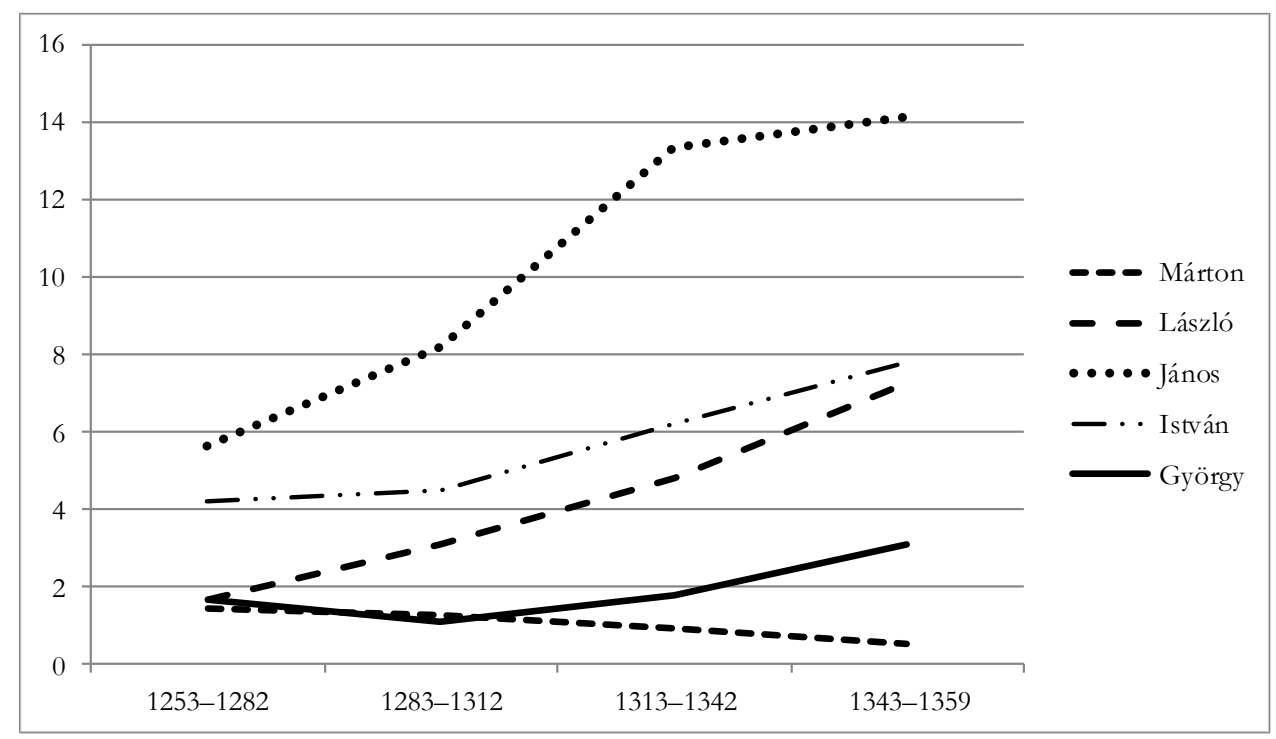

1. ábra: Egyes nevek megterheltségének változása a birtokosok körében

Az 1. ábrán öt névvel szemléltetem az itt bemutatott változásokat. Ezen jól látható a János népszerűségnövekedésének meredek íve, különösen a 13. század utolsó évtizedeiben és a 14. század elején. Az István, a Láşló és a György megterheltségének a növekedése világosan korrelál a neveket viselő szentek kultuszának történeti változásaival. Az István, mely az első vértanú, majd I. István révén már régóta a legnépszerúbb nevek egyike volt, a 14. század elejétől még kedveltebbé vált. A László kevésbé volt gyakori, hiszen Szent László kultusza több mint 100 éves késéssel követte elődjéét, ráadásul a név népszerűségéhez nem járult hozzá egy másik szent, mint az István esetében. A megterheltsége a 13. század 2. felétől azonban meredeken emelkedett, a 14. században pedig még nagyobb lendületet kapott. E változások hátterében egyértelműen az Árpádok és az Anjouk korábban már ismertetett politikája, a „szent háromkirályok” kultuszának erőteljes támogatása fedezhető fel (vö. SLíz 2011b: 150-152).

A György népszerűségének változása e két névnél változatosabb képet mutat. Gyakoriságának 13. századi fokozatos csökkenése a 14. század elején megállt, sőt növekedésbe csapott át. Ez még a korábbiaknál is egyértelműbben tükrözi, hogy mekkora hatása lehetett a névválasztásra a szentkultuszok népszerűségének, e népszerűségre pedig az uralkodói támogatásnak (Szent György katonaszent lévén ugyanis nagy tiszteletnek örvendett az Anjouk, különösen a „lovagkirály” Nagy Lajos udvarában; bővebben vö. SLÍz 2011b: 152). A fentiekkel ellentétben az akkor már 
szintén 300 éve a névanyag részét képező Márton a gyorsan előretörő nevek mögött némiképp háttérbe szorulva fokozatosan vesztett népszerúségéből.

\subsubsection{A névállomány eredet szerinti megoszlásának változása a birtokos rétegekben}

Az egyes nevek gyakoriságának változása után érdemes megvizsgálni a birtokosok névállományának eredet szerinti megoszlását, annak idôbeli változását is. Az újabb gyüités adatai természetesen itt is módosítottak a korábbi számokon (vö. SLíz 2011b: 96-102), ugyanakkor a korábbi eredmények megbízhatóságát mutatja, hogy bár minden korszakban jelentősen megnőtt az adatmennyiség a korábbihoz képest, az eredet szerinti arányok alig, legfeljebb 1-2\%-ban térnek el a korábbi értékektől. ${ }^{5}$

Az 5. táblázatból világosan kitúnik, hogy a magyar eredetű nevek arányának csökkenése és velük ellentétben a jövevénynevek arányának növekedése töretlenül folytatódott a 14. század közepén is. A bizonytalan és ismeretlen eredetú nevek arányának fokozatos csökkenése is a névanyag homogenizálódására utal, hiszen azt tükrözi, hogy egyre kevesebb benne a napjainkban már nem használatos, illetve nem azonosítható név.

\begin{tabular}{|c|c|c|c|c|c|c|c|c|c|c|}
\hline & \multicolumn{2}{|c|}{$\begin{array}{c}\text { 4. korszak } \\
(1223-1252)\end{array}$} & \multicolumn{2}{|c|}{$\begin{array}{c}\text { 3. korszak } \\
(1253-1282)\end{array}$} & \multicolumn{2}{|c|}{$\begin{array}{c}\text { 2. korszak } \\
(1283-1312)\end{array}$} & \multicolumn{2}{|c|}{$\begin{array}{c}\text { 1. korszak } \\
(1313-1342)\end{array}$} & \multicolumn{2}{|c|}{$\begin{array}{c}\text { 0. korszak } \\
(1343-1359)\end{array}$} \\
\hline & $\mathrm{db}$ & $\%$ & $\mathrm{db}$ & $\%$ & $\mathrm{db}$ & $\%$ & $\mathrm{db}$ & $\%$ & $\mathrm{db}$ & $\%$ \\
\hline Magyar & 8 & 7,34 & 69 & 8,26 & 140 & 4,49 & 140 & 2,76 & 33 & 1,37 \\
\hline Jövevény & 92 & 84,40 & 715 & 85,63 & 2858 & 91,75 & 4833 & 95,21 & 2341 & 97,38 \\
\hline Bizonytalan & 4 & 3,67 & 26 & 3,11 & 64 & 2,05 & 71 & 1,40 & 27 & 1,12 \\
\hline Ismeretlen & 5 & 4,56 & 25 & 2,99 & 53 & 1,70 & 32 & 0,63 & 3 & 0,12 \\
\hline Összesen & 109 & 100,00 & 835 & 100,00 & 3115 & 100,00 & 5076 & 100,00 & 2404 & 100,00 \\
\hline
\end{tabular}

5. táblázat: Az egyes korszakok neveinek eredet szerinti megoszlása a világi birtokosok körében

A 6. táblázatból is egyértelműen látszik, hogy a jövevénynevek csoportján belül már a 13. század közepén uralkodó szerepben lévő görög-latin eredetû nevek a 14. század közepére csaknem e kategória 90\%-át tették ki, azaz hozzávetőlegesen 130 év alatt közel 30\%-kal nőtt az arányuk. Ha pedig nem a jövevényneveken, hanem az összes kategórián belüli arányukat vesszük, még feltűnőbb, csaknem 36\%-os

\footnotetext{
${ }^{5}$ Mivel a 4. és 3. korszakból nagyságrendekkel kevesebb adat áll rendelkezésünkre, ezek értékeit a torzítás miatt nem szerencsés összevetni a többi korszakéval. Ennek ellenére nem érdektelen közölni őket, mivel az egyes, eredet szerinti csoportok adott időszakon belüli megoszlását a maguk viszonylagosságában is képesek tükrözni.
} 
gyarapodást regisztrálhatunk. A többi idegen eredetû csoportban ezzel szemben visszaszorulás tapasztalható. Míg azonban a török és a német eredetú nevek aránya rohamosan csökkent, addig a szláv nevek aránya a 13. század második felében tapasztalható nagyobb mértékú csökkenés után stagnált, majd a 14. század közepére ismét felívelni látszik. E meglepőnek tűnő változás okára a névféleségeknek és az átlagos megterheltségnek a vizsgálata világíthat majd rá.

\begin{tabular}{|c|c|c|c|c|c|c|c|c|c|c|}
\hline & \multicolumn{2}{|c|}{$\begin{array}{c}4 . \text { korszak } \\
(1223-1252)\end{array}$} & \multicolumn{2}{|c|}{$\begin{array}{c}\text { 3. korszak } \\
(1253-1282)\end{array}$} & \multicolumn{2}{|c|}{$\begin{array}{r}2 . \text { korszak } \\
(1283-1312)\end{array}$} & \multicolumn{2}{|c|}{$\begin{array}{c}1 . \text { korszak } \\
(1313-1342)\end{array}$} & \multicolumn{2}{|c|}{$\begin{array}{c}\text { 0. korszak } \\
(1343-1359)\end{array}$} \\
\hline & $\mathrm{db}$ & $\%$ & $\mathrm{db}$ & $\%$ & $\mathrm{db}$ & $\%$ & $\mathrm{db}$ & $\%$ & $\mathrm{db}$ & $\%$ \\
\hline Török & 8 & $\begin{array}{c}8,70 \\
(7,34)\end{array}$ & 28 & $\begin{array}{c}3,92 \\
(3,35)\end{array}$ & 50 & $\begin{array}{c}1,75 \\
(1,61)\end{array}$ & 38 & $\begin{array}{c}0,79 \\
(0,75)\end{array}$ & 10 & $\begin{array}{c}0,43 \\
(0,42)\end{array}$ \\
\hline Görög-latin & 56 & $\begin{array}{c}60,87 \\
(51,38) \\
\end{array}$ & 518 & $\begin{array}{c}72,45 \\
(62,04) \\
\end{array}$ & 2363 & $\begin{array}{c}82,68 \\
(75,86) \\
\end{array}$ & 4220 & $\begin{array}{c}87,32 \\
(83,14) \\
\end{array}$ & 2096 & $\begin{array}{c}89,53 \\
(87,19) \\
\end{array}$ \\
\hline Német & 18 & $\begin{array}{c}19,57 \\
(16,51) \\
\end{array}$ & 92 & $\begin{array}{c}12,87 \\
(11,02) \\
\end{array}$ & 193 & $\begin{array}{c}6,75 \\
(6,20) \\
\end{array}$ & 193 & $\begin{array}{c}3,99 \\
(3,80) \\
\end{array}$ & 32 & $\begin{array}{c}1,37 \\
(1,33) \\
\end{array}$ \\
\hline Szláv & 10 & $\begin{array}{l}10,87 \\
(9,17) \\
\end{array}$ & 55 & $\begin{array}{c}7,69 \\
(6,59) \\
\end{array}$ & 201 & $\begin{array}{r}7,03 \\
(6,45) \\
\end{array}$ & 333 & $\begin{array}{r}6,89 \\
(6,56) \\
\end{array}$ & 193 & $\begin{array}{c}8,24 \\
(8,03) \\
\end{array}$ \\
\hline Francia & - & - & 7 & $\begin{array}{c}0,98 \\
(0,84) \\
\end{array}$ & 24 & $\begin{array}{c}0,84 \\
(0,77) \\
\end{array}$ & 35 & $\begin{array}{c}0,72 \\
(0,69) \\
\end{array}$ & 6 & $\begin{array}{c}0,26 \\
(0,25) \\
\end{array}$ \\
\hline Bizonytalan & - & - & 9 & $\begin{array}{c}1,26 \\
(1,08)\end{array}$ & 24 & $\begin{array}{c}0,84 \\
(0,77)\end{array}$ & 9 & $\begin{array}{c}0,19 \\
(0,18)\end{array}$ & 5 & $\begin{array}{c}0,21 \\
(0,21)\end{array}$ \\
\hline Ismeretlen & - & - & 6 & $\begin{array}{c}0,84 \\
(0,72)\end{array}$ & 3 & $\begin{array}{c}0,10 \\
(0,09)\end{array}$ & 5 & $\begin{array}{c}0,10 \\
(0,09)\end{array}$ & 1 & $\begin{array}{c}0,04 \\
(0,04)\end{array}$ \\
\hline Összesen & 92 & 100,00 & 715 & 100,00 & 2858 & 100,00 & 4833 & 100,00 & 2341 & 100,00 \\
\hline
\end{tabular}

6. táblázat: A jövevénynevek megoszlása eredet szerint a világi birtokosok körében az egyes korszakokban

A 7. és 8. táblázat alapján világosan áll előttünk a névanyag homogenizálódásának folyamata, üteme. Míg a 13. század második felében-végén a magyar nevek aránya már 10\%, sőt a századfordulóra már 5\% alá csökkent, addig a magyar eredetű névféleségeknek még csaknem az ötöde magyar eredetú volt ebben az időszakban. A magyar eredetû nevek tehát még tartották magukat, habár már jócskán háttérbe szorulva. Ugyanakkor egy-egy név népszerűsége jóval kisebb volt, mint a jövevénynevek esetében, vagyis állományuk változatosabb volt. Ez természetes következménye a világi és az egyházi névadás különbségének: egy nyitott névállomány természetes módon mindig heterogénebb, mint egy zárt, véges számú elemmel rendelkező, hiszen az utóbbi elemei kényszerúen gyakrabban ismétlődnek. A nagyobb mértékủ változás, úgy tűnik, a 14. század első felében zajlott le: ekkor számos magyar eredetú név eltűnt a névállományból.

Az idegen eredetú névféleségek nyelvenként, illetve nyelvcsaládonként való vizsgálata természetesen a görög-latin eredetú nevek uralkodó voltát mutatja, ugyanakkor 
fölényük e szempontból már jóval kisebbnek, állományuk a többi nyelvből eredő csoportnál kevésbé változatosnak mutatkozik.

\begin{tabular}{|c|c|c|c|c|c|c|c|c|c|c|}
\hline & \multicolumn{2}{|c|}{$\begin{array}{c}\text { 4. korszak } \\
(1223-1252)\end{array}$} & \multicolumn{2}{|c|}{$\begin{array}{c}\text { 3. korszak } \\
(1253-1282)\end{array}$} & \multicolumn{2}{|c|}{$\begin{array}{c}\text { 2. korszak } \\
(1283-1312)\end{array}$} & \multicolumn{2}{|c|}{$\begin{array}{c}\text { 1. korszak } \\
(1313-1342)\end{array}$} & \multicolumn{2}{|c|}{$\begin{array}{c}\text { 0. korszak } \\
(1343-1359)\end{array}$} \\
\hline & $\mathrm{db}$ & $\%$ & $\mathrm{db}$ & $\%$ & $\mathrm{db}$ & $\%$ & $\mathrm{db}$ & $\%$ & $\mathrm{db}$ & $\%$ \\
\hline Magyar & 8 & 9,20 & 58 & 17,11 & 99 & 18,33 & 77 & 15,65 & 20 & 11,98 \\
\hline Jövevény & 70 & 80,46 & 238 & 70,21 & 357 & 66,11 & 346 & 70,33 & 134 & 80,24 \\
\hline Bizonytalan & 4 & 4,60 & 20 & 5,90 & 42 & 7,78 & 43 & 8,74 & 10 & 5,99 \\
\hline Ismeretlen & 5 & 5,75 & 23 & 6,78 & 42 & 7,78 & 26 & 5,28 & 3 & 1,80 \\
\hline Összesen & 87 & 100,00 & 339 & 100,00 & 540 & 100,00 & 492 & 100,00 & 167 & 100,00 \\
\hline
\end{tabular}

7. táblázat: A világi birtokosok névféleségeinek eredet szerinti megoszlása az egyes korszakokban

\begin{tabular}{|c|c|c|c|c|c|c|c|c|c|c|}
\hline & \multicolumn{2}{|c|}{$\begin{array}{c}\text { 4. korszak } \\
(1223-1252)\end{array}$} & \multicolumn{2}{|c|}{$\begin{array}{c}\text { 3. korszak } \\
(1253-1282)\end{array}$} & \multicolumn{2}{|c|}{$\begin{array}{c}2 . \text { korszak } \\
(1283-1312)\end{array}$} & \multicolumn{2}{|c|}{$\begin{array}{c}\text { 1. korszak } \\
(1313-1342)\end{array}$} & \multicolumn{2}{|c|}{$\begin{array}{c}\text { 0. korszak } \\
(1343-1359)\end{array}$} \\
\hline & $\mathrm{db}$ & $\%$ & $\mathrm{db}$ & $\%$ & $\mathrm{db}$ & $\%$ & $\mathrm{db}$ & $\%$ & $\mathrm{db}$ & $\%$ \\
\hline Török & 7 & $\begin{array}{l}10,00 \\
(8,05) \\
\end{array}$ & 17 & $\begin{array}{c}7,14 \\
(5,01) \\
\end{array}$ & 33 & $\begin{array}{c}9,24 \\
(6,11) \\
\end{array}$ & 27 & $\begin{array}{c}7,80 \\
(5,49) \\
\end{array}$ & 7 & $\begin{array}{c}5,22 \\
(4,19) \\
\end{array}$ \\
\hline Görög-latin & 38 & $\begin{array}{c}54,29 \\
(43,68)\end{array}$ & $\begin{array}{c}10 \\
7\end{array}$ & $\begin{array}{l}44,96 \\
(31,56)\end{array}$ & 147 & $\begin{array}{c}41,18 \\
(27,22)\end{array}$ & 146 & $\begin{array}{c}42,20 \\
(29,67)\end{array}$ & 82 & $\begin{array}{c}61,19 \\
(49,10)\end{array}$ \\
\hline Német & 16 & $\begin{array}{c}22,86 \\
(18,39)\end{array}$ & 60 & $\begin{array}{c}25,21 \\
(17,70) \\
\end{array}$ & 89 & $\begin{array}{c}24,93 \\
(16,48)\end{array}$ & 90 & $\begin{array}{c}26,01 \\
(18,29)\end{array}$ & 22 & $\begin{array}{r}16,42 \\
(13,17)\end{array}$ \\
\hline Szláv & 9 & $\begin{array}{c}12,86 \\
(10,34)\end{array}$ & 37 & $\begin{array}{c}15,55 \\
(10,91) \\
\end{array}$ & 59 & $\begin{array}{c}16,53 \\
(10,93) \\
\end{array}$ & 61 & $\begin{array}{c}17,63 \\
(12,40) \\
\end{array}$ & 16 & $\begin{array}{l}11,94 \\
(9,58) \\
\end{array}$ \\
\hline Francia & - & - & 3 & $\begin{array}{c}1,26 \\
(0,88) \\
\end{array}$ & 6 & $\begin{array}{r}1,68 \\
(1,11) \\
\end{array}$ & 8 & $\begin{array}{c}2,31 \\
(1,63)\end{array}$ & 2 & $\begin{array}{c}1,49 \\
(1,20)\end{array}$ \\
\hline Bizonytalan & - & - & 8 & $\begin{array}{c}3,36 \\
(2,36)\end{array}$ & 20 & $\begin{array}{c}5,60 \\
(3,70)\end{array}$ & 9 & $\begin{array}{c}2,60 \\
(1,83)\end{array}$ & 4 & $\begin{array}{c}2,99 \\
(2,40)\end{array}$ \\
\hline Ismeretlen & - & - & 6 & $\begin{array}{c}2,52 \\
(1,77) \\
\end{array}$ & 3 & $\begin{array}{c}0,84 \\
(0,56) \\
\end{array}$ & 5 & $\begin{array}{c}1,45 \\
(1,02) \\
\end{array}$ & 1 & $\begin{array}{c}0,75 \\
(0,60) \\
\end{array}$ \\
\hline Összesen & 70 & 100,00 & 238 & 100,00 & 357 & 100,00 & 346 & 100,00 & 134 & 100,00 \\
\hline
\end{tabular}

8. táblázat: A jövevénynevek névféleségeinek eredet szerinti megoszlása a világi birtokosok körében az egyes korszakokban

\begin{tabular}{|l|c|c|c|c|c|}
\hline & $\begin{array}{c}\text { 4. korszak } \\
\mathbf{( 1 2 2 3 - 1 2 5 2 )}\end{array}$ & $\begin{array}{c}\text { 3. korszak } \\
\mathbf{( 1 2 5 3 - 1 2 8 2 )}\end{array}$ & $\begin{array}{c}\text { 2. korszak } \\
\mathbf{( 1 2 8 3 - 1 3 1 2 )}\end{array}$ & $\begin{array}{c}\text { 1. korszak } \\
\mathbf{( 1 3 1 3 - 1 3 4 2 )}\end{array}$ & $\begin{array}{c}\text { 0. korszak } \\
\mathbf{( 1 3 4 3 - 1 3 5 9 )}\end{array}$ \\
\hline Magyar & 1,00 & 1,19 & 1,41 & 1,82 & 1,65 \\
\hline Jövevény & 1,28 & 3,00 & 8,01 & 13,97 & 17,47 \\
\hline Bizonytalan & 1,00 & 1,30 & 1,52 & 1,65 & 2,70 \\
\hline Ismeretlen & 1,00 & 1,09 & 1,26 & 1,23 & 1,00 \\
\hline Összes & 1,25 & 2,46 & 5,77 & 10,32 & 14,40 \\
\hline
\end{tabular}

9. táblázat: A nevek eredet szerinti megoszlásának gyakorisági mutatói az egyes korszakokban, a világi birtokosok körében 
A névviselők számát a névféleségekével elosztva kirajzolódik előttünk, hogy átlagosan hányan viselték egy-egy eredet szerinti kategória neveit. A 9. táblázat gyakorisági mutatói szerint a 13. század végéig nemcsak a jövevény-, hanem a magyar nevek megterheltsége is folyamatosan nôtt; a visszaesés a 14. század első felében indulhatott meg. Ennek az általános növekedésnek a hátterében részben bizonyára szintén a nyitottról a zárt névállományra való áttérés állhat: a magyar eredetű nevek névféleségeinek száma folyamatosan csökkent, az egyes neveket azonban többen viselték, vagyis e kategória is vesztett változatosságából. A kereszténység elterjedésével ugyanis feltehetőleg a magyar eredetű neveket is egyre inkább a korábbiak mintájára, már létező névként, a jövevénynevekhez hasonlóan egy már meglévő névállományból választották, azaz nem alkotott névként, hanem listanévként adták (az utóbbi terminusokra l. HOFFMANN 2008). Ebben bizonyára szerepet játszott az is, hogy a feudális berendezkedéssel az előkelő rétegben fokozottabban jelentkezett a névöröklés jelensége, hiszen ez is egyfajta eszközként szolgálhatott a leszármazás, illetve az azon alapuló birtokjog kifejezésére.

A jövevénynevek jelentős megterheltsége mögött természetesen a görög-latin eredetű nevek állnak; gyakorisági mutatójuk nyomasztó fölényben van a többi csoportéval szemben (10. táblázat).

\begin{tabular}{|l|c|c|c|c|c|}
\hline & $\begin{array}{c}\text { 4. korszak } \\
\mathbf{( 1 2 2 3 - 1 2 5 2 )}\end{array}$ & $\begin{array}{c}\text { 3. korszak } \\
\mathbf{( 1 2 5 3 - 1 2 8 2 )}\end{array}$ & $\begin{array}{c}\text { 2. korszak } \\
\mathbf{( 1 2 8 3 - 1 3 1 2 )}\end{array}$ & $\begin{array}{c}\text { 1. korszak } \\
\mathbf{( 1 3 1 3 - 1 3 4 2 )}\end{array}$ & $\begin{array}{c}\text { 0. korszak } \\
\mathbf{( 1 3 4 3 - 1 3 5 9 )}\end{array}$ \\
\hline Török & 1,14 & 1,65 & 1,52 & 1,41 & 1,43 \\
\hline Görög-latin & 1,47 & 4,84 & 16,07 & 28,90 & 25,56 \\
\hline Német & 1,13 & 1,53 & 2,17 & 2,14 & 1,45 \\
\hline Szláv & 1,11 & 1,49 & 3,41 & 5,46 & 12,06 \\
\hline Francia & - & 2,33 & 4,00 & 4,38 & 3,00 \\
\hline Bizonytalan & - & 1,13 & 1,20 & 1,00 & 1,25 \\
\hline Ismeretlen & - & 1,00 & 1,00 & 1,00 & 1,00 \\
\hline Összesen & 1,28 & 3,00 & 8,01 & 13,98 & 17,47 \\
\hline
\end{tabular}

10. táblázat: A jövevénynevek eredet szerinti megoszlásának gyakorisági mutatói az egyes korszakokban, a világi birtokosok körében

A francia eredetű nevek gyakorisága szintén magasnak tűnik a névállományból való részesedésükhöz képest. Ez annak köszönhető, hogy mindössze néhány francia eredetű név volt használatos, melyek a lovagi kultúra utóvirágzásában, illetve a 13. századi névviselők után öröklődve még a 14. században is jelen voltak a névállományban. Ebben az összevetésben ismét kitűnik a szláv eredetű nevek gyakoriságának hirtelen megugrása a 14. század közepére. A gyakorisági mutató világosan jelzi, hogy ez nem a névállomány bővülésének, azaz újabb nevek használatba vételének, hanem a megterheltség feltűnő mértékű növekedésének a következménye. Ennek magyarázatát minden bizonnyal a László korábban látott, a 13. század végétôl meredeken felfelé ívelő népszerűségében láthatjuk. 
Összességében áttekintve tehát a mintegy 130 év alatt bekövetkező változásokat, azt tapasztalhatjuk, hogy a birtokosok névállományának átlagos megterheltsége (az összes névviselő számának és az összes névféleségnek a hányadosa) a 13. század közepéig kisebb mértékben, attól kezdve azonban meredeken emelkedik (2. ábra). Ennek magyarázata pedig, mint láthattuk, a görög-latin eredetű névállomány gyors egyeduralkodóvá válása, a többi eredet szerinti csoport erôteljes ütemú kiszorulása a névhasználatból. Bár a vizsgálatot a forrásadottságok miatt csak a birtokosok névállományára volt lehetôségem elvégezni, a többi réteg névkészletének eredet szerinti megoszlását bemutató táblázatok arra engednek következtetni, hogy a változás minden társadalmi rétegben hasonlóképpen zajlott, legfeljebb a növekedés ütemében lehettek kisebb-nagyobb eltérések.

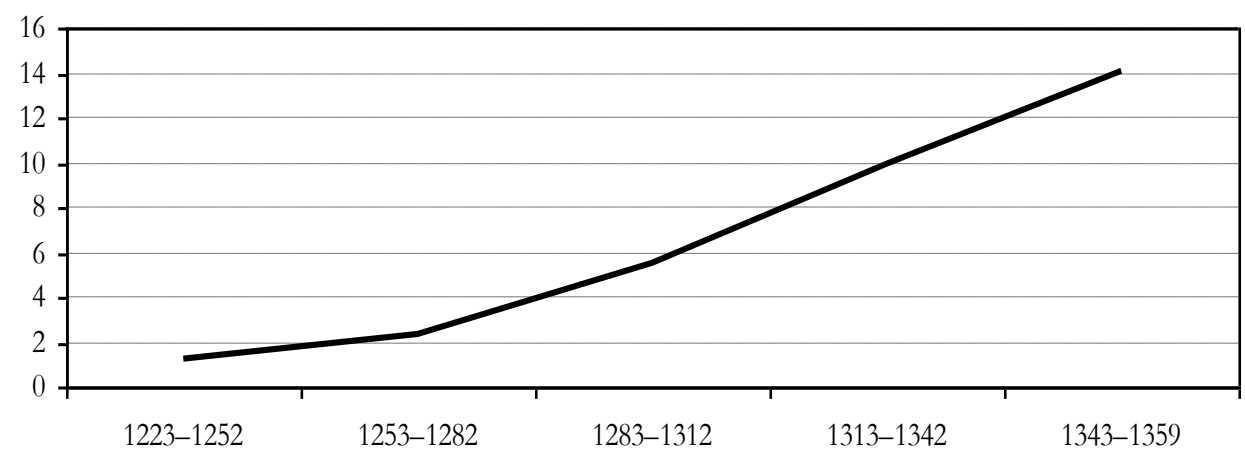

2. ábra: A birtokosok névállományának megterheltsége (1223-1359)

\subsection{Női nevek}

\subsubsection{A leggyakoribb női nevek a különböző rétegekben}

A női nevek korpusza több mint a kétszeresére nőtt az újabb gyújtés eredményeképpen, de a férfinevek korpuszához képest még így is meglehetősen kevés elemet tartalmaz, ezért különösen a kis elemszámú alsóbb rétegekben jelentős mértékú torzítással kell számolnunk. Bár a legtöbb adat itt is a birtokos rétegból származik, a 11. táblázatból annyi mégis megállapítható, hogy az első néhány helyen nincsenek nagy különbségek a társadalmi osztályok között: az Erssébet és a Margit továbbra is a legmegterheltebb nevek, mellettük pedig az Ilona és az Anna található még meg minden névlista elején. (A mindössze egyszer előforduló neveket a táblázat nem tartalmazza.) 


\begin{tabular}{|c|c|c|c|c|c|c|}
\hline \multirow{2}{*}{ Pozíció } & \multicolumn{3}{|l|}{ Birtokos } & \multicolumn{3}{|c|}{ Polgár } \\
\hline & név & $\mathrm{db}$ & $\%$ & név & $\mathrm{db}$ & $\%$ \\
\hline 1. & Erssébet & 72 & 15,79 & Margit & 8 & 22,22 \\
\hline 2. & Margit & 58 & 12,72 & Erssébet, Klára & 6 & 16,67 \\
\hline 3. & Katalin & 56 & 12,28 & Katalin & 5 & 13,89 \\
\hline 4. & Klára & 47 & 10,31 & Magdolna, Sebe & 3 & 8,33 \\
\hline 5. & Ilona & 44 & 9,65 & Anna & 2 & 5,56 \\
\hline 6. & Anna & 34 & 7,46 & & & \\
\hline 7. & Sebe & 11 & 2,41 & & & \\
\hline 8. & Kunigunda, Csala & 10 & 2,19 & & & \\
\hline 9. & Ágnes & 8 & 1,75 & & & \\
\hline 10. & $\begin{array}{l}\text { Izolda, } \\
\text { Skolasqtika }\end{array}$ & 7 & 1,54 & & & \\
\hline 11. & Adelheid, Barbara & 6 & 1,32 & & & \\
\hline 12. & Jolanta, Magdolna & 5 & 1,10 & & & \\
\hline 13. & Agota & 4 & 0,88 & & & \\
\hline 14. & Imus, Nyeste, Venus & 3 & 0,66 & & & \\
\hline 15. & Cecilia, Lúcia, Ruæsint, Viola & 2 & 0,44 & & & \\
\hline $\begin{array}{c}\text { Összes } \\
\text { név }\end{array}$ & & 456 & 100,00 & & 36 & 100,00 \\
\hline \multirow{2}{*}{ Pozíció } & \multicolumn{3}{|c|}{ Mezővárosi polgár } & \multicolumn{3}{|c|}{ Jobbágy } \\
\hline & név & $\mathrm{db}$ & $\%$ & név & $\mathrm{db}$ & $\%$ \\
\hline 1. & Ilona & 4 & 20,00 & $\begin{array}{l}\text { Errsébet, } \\
\text { Ilona }\end{array}$ & 4 & 13,80 \\
\hline 2. & $\begin{array}{l}\text { Anna, } \\
\text { Erzsébet, Sebe }\end{array}$ & 3 & 15,00 & Katalin & 3 & 10,34 \\
\hline 3. & Margit, Nyeste & 2 & 10,00 & Anna, Csala, Margit & 2 & 6,90 \\
\hline $\begin{array}{l}\text { Összes } \\
\text { név }\end{array}$ & & 20 & 100,00 & & 29 & 100,00 \\
\hline
\end{tabular}

11. táblázat: Az egyes rétegek leggyakoribb női nevei

A korábban elemzett korpuszhoz képest újabb nevek is megjelentek: a göröglatin eredetû Cecília, Lúcia és a bizonytalan eredetű Ruæsint (vö. BERRÁR 1952: 47) is a többször előforduló nevek közé tartozik, a szintén görög-latin eredetủ Dominika, Judit, Krisztina és Orsolya viszont csak egyszer bukkant fel. A Mária továbbra is rendkívül ritka, az új korpuszban mindössze egy alakváltozata bukkan fel (1344: Marus, 
AO. 4: 417), így a teljes korpuszban mindössze három adattal képviselteti magát. (E ritkaság okairól bővebben l. SLíz 2011b: 146-147.) A görög-latin eredetû nevek szinte kizárólag az Újszövetségből vagy a martirológiumokból származnak; az ószövetségiek közül egyedül a Judit, illetve egy zsidó nő neveként a Sába említhető (1349, AO. 5: 291).

\subsubsection{A női nevek eredet szerinti megoszlása a különböző rétegekben}

Az egyesített korpusz a korábbi vizsgálatnál (SLíz 2011b: 126-129) is nagyobbnak mutatja a jövevénynevek arányát (vö. 12. táblázat). Ezek eredet szerinti megoszlását tekintve továbbra is görög-latin eredetűek teszik ki a korpusz túlnyomó részét, és török eredetű ezúttal sem került elő a forrásokból (vö. 13. táblázat).

Bár egyes városok jelentős német és vallon származású lakossága miatt azt várnánk, hogy a polgárasszonyok névanyagában nagyobb arányban jelennek meg a német vagy francia eredetú elemek, a birtokosokon kívül mindegyik rétegben csak egy német eredetú névvel és egyetlen franciával sem találkozunk. Meg kell ugyanakkor jegyezni, hogy ennek nemcsak a görög-latin eredetű nevek közös európai névkincshez való tartozása az oka, hanem az adathiány is. A női nevek közismerten ritka előfordulása az oklevelekben nagy valószínűséggel még akkor sem tenné lehetôvé, hogy valóban hiteles képet kapjunk a polgárasszonyok névállományáról, ha kifejezetten városi oklevelekből állítanánk össze a korpuszt; bár kétségtelenül hitelesebb képet adnának róla, mint a jelen gyüjtés.

\begin{tabular}{|c|c|c|c|c|c|c|c|c|}
\hline & \multicolumn{2}{|c|}{ Birtokos } & \multicolumn{2}{|c|}{ Polgár } & \multicolumn{2}{|c|}{$\begin{array}{l}\text { Mezővárosi } \\
\text { polgár }\end{array}$} & \multicolumn{2}{|c|}{ Jobbágy } \\
\hline & $\mathrm{db}$ & $\%$ & $\mathrm{db}$ & $\%$ & $\mathrm{db}$ & $\%$ & $\mathrm{db}$ & $\%$ \\
\hline Magyar & 36 & 7,89 & 5 & 13,89 & 4 & 20,00 & 5 & 17,24 \\
\hline Jövevény & 406 & 89,04 & 31 & 86,11 & 15 & 75,00 & 23 & 79,31 \\
\hline Bizonytalan & 6 & 1,32 & 0 & 0,00 & 1 & 5,00 & 0 & 0,00 \\
\hline Ismeretlen & 8 & 1,75 & 0 & 0,00 & 0 & 0,00 & 1 & 3,45 \\
\hline Összesen & 456 & 100,00 & 36 & 100,00 & 20 & 100,00 & 29 & 100,00 \\
\hline
\end{tabular}

12. táblázat: A női nevek eredet szerinti megoszlása a különböző rétegekben

A korábbi korpuszhoz képest kiemelendő változás, hogy az úrnők körében is felbukkant két szláv eredetú név: Casuch (1358, AO. 7: 325; vö. FNESz. ${ }^{4}$ Kazsô) és Precana (1349, AO. 5: 284); az első Abaújból, a másik pedig Kőrösből. Ami a magyar eredetűeket illeti, a korábbi korpuszhoz képest csak két újabb név került elő: a Nuz (1344, AO. 4: 462; 'nyuszt', vö. TESz.) és a Rusa (1353, AO. 6: 74-75). Nem meglepő módon mindkettő a női nevekre tipikusan jellemzô jelentésmezőkbe tartozó közszavakból (virágok és kis prémes állatok) keletkezett. 


\begin{tabular}{|l||c|c||c|c||c|c||c|c|}
\hline \multicolumn{1}{|c||}{} & \multicolumn{2}{c||}{ Birtokos } & \multicolumn{2}{c||}{ Polgár } & \multicolumn{2}{c|}{$\begin{array}{c}\text { Mezóvárosi } \\
\text { polgár }\end{array}$} & \multicolumn{2}{c|}{ Jobbágy } \\
\cline { 2 - 9 } & $\mathbf{d b}$ & $\mathbf{\%}$ & $\mathbf{d b}$ & $\mathbf{\%}$ & $\mathbf{d b}$ & $\mathbf{\%}$ & $\mathbf{d b}$ & $\%$ \\
\hline Török & 0 & 0,00 & 0 & 0,00 & 0 & 0,00 & 0 & 0,00 \\
\hline Görög-latin & 347 & $\begin{array}{c}85,47 \\
(76,10)\end{array}$ & 30 & $\begin{array}{c}96,77 \\
(83,33)\end{array}$ & 13 & $\begin{array}{c}86,67 \\
(65,00)\end{array}$ & 20 & $\begin{array}{c}86,96 \\
(68,97)\end{array}$ \\
\hline Német & 42 & $\begin{array}{c}10,34 \\
(9,21)\end{array}$ & 1 & $\begin{array}{c}3,23 \\
(2,78)\end{array}$ & 1 & $\begin{array}{c}6,67 \\
(5,00)\end{array}$ & 1 & $\begin{array}{c}4,35 \\
(3,45)\end{array}$ \\
\hline Szláv & 2 & $\begin{array}{c}0,49 \\
(0,44)\end{array}$ & 0 & 0,00 & 0 & 0,00 & 1 & $\begin{array}{c}4,35 \\
(3,45)\end{array}$ \\
\hline Francia & 5 & $\begin{array}{c}1,23 \\
(1,10)\end{array}$ & 0 & 0,00 & 0 & 0,00 & 0 & 0,00 \\
\hline Bizonytalan & 6 & $\begin{array}{c}1,48 \\
(1,32)\end{array}$ & 0 & 0,00 & 1 & $\begin{array}{c}6,67 \\
(5,00)\end{array}$ & 1 & $\begin{array}{c}4,35 \\
(3,45)\end{array}$ \\
\hline Ismeretlen & 2 & $\begin{array}{c}0,49 \\
(0,44)\end{array}$ & 0 & 0,00 & 0 & 0,00 & 0 & 0,00 \\
\hline Összesen & 406 & 100,00 & 31 & 100,00 & 15 & 100,00 & 23 & 100,00 \\
\hline
\end{tabular}

13. táblázat: A jövevénynevek eredet szerinti megoszlása társadalmi rétegenként a nők körében

Az egyetlen, de ötször is előforduló francia eredetű név a Jolánta. Ezt a korábbi korpusz elemzésekor és a névtáramban is még a görög-latin eredetű nevek közé soroltam (vö. SLíz 2011a. Jolenth), újabb vizsgálataim alapján azonban (vö. 2.4.1.1.2. fejezet) arra a következtetésre jutottam, hogy a név különféle származtatásai közül a franciából való eredeztetés mutatkozik valószínúbbnek.

A névféleségek megoszlását is megvizsgálva azt láthatjuk, hogy az első korpusz elemzésével kapott eredményeknél jelentősen, az akkori 61,22\%-nál (SLíz 2011b: 128) több mint 12\%-kal magasabb a jövevény névféleségek aránya az előkelő nők körében (vö. 14. táblázat). Ez az újonnan megjelenő szláv neveknek, valamint a bizonytalan eredetủek viszonylag magas arányának köszönhető. Az utóbbiak egyike az újabb korpuszban háromszor is megjelenő Nyeste, amely egyaránt lehet a magyar nyest szó származéka és az Anasztáiria alakváltozata is (vö. BERRÁR 1950: 254-255, RÁCZ 1959-1960: 78). A Manga (1358, AO. 7: 123) szintén több név (Magdolna, Margit) változata lehet, de más eredet sem zárható ki. A Chenez (1344, AO. 4: 391) feltehetőleg a Kunigunda egyik változata (vö. Kenys, BERRÁR 1952: 40).

A német eredetű nevek kapcsán kiemelendő, hogy többük egyházi, görög-latin eredetű nevek német változata. Az Elisabeth német változata például az El₹. (1358, AO. 7: 366, Szepes m.), a Kathariná-é a Katbren (1358, AO. 7: 438-439, Szepes m.). Német alapnévből keletkezhettek a következő névváltozatok: Goldus (1346, AO. 4: 571, Szepes m.; vö. BERRÁR 1952: 43), Imus (1358, AO. 7: 366, Szepes m.; vö. FÖRSTEMANN 1900/19662: 949. Im- kezdetú nevek), Sela (1346, AO. 4: 556, Szepes 
m.; vsz. a Giselá-ból). Német eredetű a polgárasszonyok köréből előkerülő Hylla is (1344, AO. 4: 417, Szepes m.; vö. FÖRSTEMANN 1900/19662: 817. Hilla).

\begin{tabular}{|c|c|c|c|c|c|c|c|c|}
\hline & \multicolumn{2}{|c|}{ Birtokos } & \multicolumn{2}{|c|}{ Polgár } & \multicolumn{2}{|c|}{$\begin{array}{l}\text { Mezóvárosi } \\
\text { polgár }\end{array}$} & \multicolumn{2}{|c|}{ Jobbágy } \\
\hline & $\mathrm{db}$ & $\%$ & $\mathrm{db}$ & $\%$ & $\mathrm{db}$ & $\%$ & $\mathrm{db}$ & $\%$ \\
\hline Magyar & 16 & 20,00 & 4 & 20,00 & 3 & 20,00 & 4 & 23,53 \\
\hline Jövevény & 59 & 73,75 & 16 & 80,00 & 11 & 73,33 & 12 & 70,59 \\
\hline Bizonytalan & 5 & 6,25 & 0 & 0,00 & 1 & 6,67 & 0 & 0,00 \\
\hline Ismeretlen & 0 & 0,00 & 0 & 0,00 & 0 & 0,00 & 1 & 5,88 \\
\hline Összesen & 80 & 100,00 & 20 & 100,00 & 15 & 100,00 & 17 & 100,00 \\
\hline
\end{tabular}

14. táblázat: A névféleségek eredet szerinti megoszlása társadalmi rétegenként a nők körében

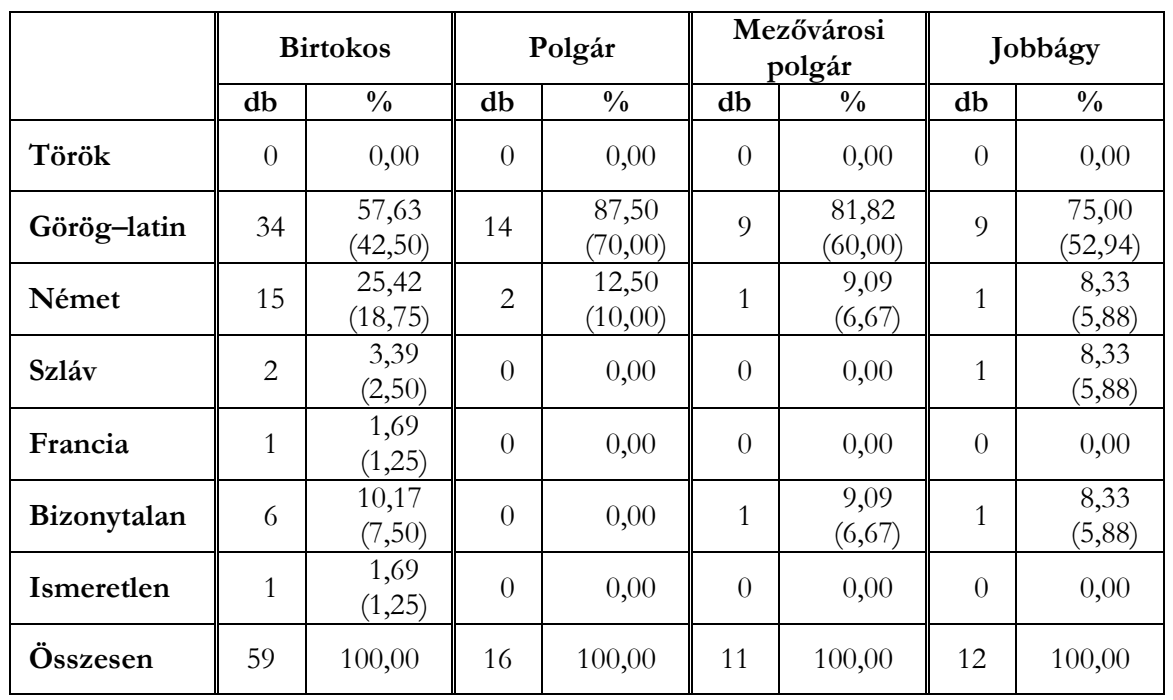

15. táblázat: A névféleségek eredet szerinti megoszlása a jövevényneveken belül társadalmi rétegenként a nők körében

\subsubsection{Az úrnők névállományának időbeli változása eredet szerint}

Mivel női névből kevés áll rendelkezésünkre, nem érdemes a férfinevekhez hasonlóan, egyes nevekre lebontva vizsgálni az időbeli változást. Még a korpusz leggyakoribb neveiből is csak néhány fordul elő ugyanis időszakonként, így e véletlenszerű adatok még megközelítőleg sem mutatnák a nevek valós népszerűségét. Az eredet szerinti megoszlás időbeli változását azonban már nagyobb eséllyel lehet vizsgálni (vö. 16-17. táblázat). 


\begin{tabular}{|c|c|c|c|c|c|c|}
\hline & \multicolumn{2}{|c|}{$\begin{array}{c}\text { 2. korszak } \\
(1283-1312)\end{array}$} & \multicolumn{2}{|c|}{$\begin{array}{c}\text { 1. korszak } \\
(1313-1342)\end{array}$} & \multicolumn{2}{|c|}{$\begin{array}{c}\text { 0. korszak } \\
(1343-1359)\end{array}$} \\
\hline & $\mathrm{db}$ & $\%$ & $\mathrm{db}$ & $\%$ & db & $\%$ \\
\hline Magyar & 12 & 10,43 & 13 & 6,81 & 10 & 7,41 \\
\hline Jövevény & 95 & 82,61 & 174 & 91,10 & 123 & 91,11 \\
\hline Bizonytalan & 2 & 1,74 & 2 & 1,05 & 2 & 1,48 \\
\hline Ismeretlen & 6 & 5,22 & 2 & 1,05 & 0 & 0,00 \\
\hline Összesen & 115 & 100,00 & 191 & 100,00 & 135 & 100,00 \\
\hline
\end{tabular}

16. táblázat: Az úrnők neveinek eredet szerinti megoszlása az egyes korszakokban

\begin{tabular}{|c|c|c|c|c|c|c|}
\hline & \multicolumn{2}{|c|}{$\begin{array}{c}\text { 2. korszak } \\
(1283-1312)\end{array}$} & \multicolumn{2}{|c|}{$\begin{array}{c}\text { 1. korszak } \\
(1313-1342)\end{array}$} & \multicolumn{2}{|c|}{$\begin{array}{c}\text { 0. korszak } \\
(1343-1359)\end{array}$} \\
\hline & $\mathrm{db}$ & $\%$ & $\mathrm{db}$ & $\%$ & $\mathrm{db}$ & $\%$ \\
\hline Török & 0 & 0,00 & 0 & 0,00 & 0 & 0,00 \\
\hline Görög-latin & 74 & $\begin{array}{c}77,89 \\
(64,35)\end{array}$ & 151 & $\begin{array}{c}86,78 \\
(79,06)\end{array}$ & 110 & $\begin{array}{r}89,43 \\
(81,48\end{array}$ \\
\hline Német & 11 & $\begin{array}{l}11,58 \\
(9,57)\end{array}$ & 19 & $\begin{array}{l}10,92 \\
(9,95)\end{array}$ & 10 & $\begin{array}{r}8,13 \\
(7,41)\end{array}$ \\
\hline Szláv & 0 & 0,00 & 0 & 0,00 & 2 & $\begin{array}{c}1,63 \\
(1,48)\end{array}$ \\
\hline Francia & 4 & $\begin{array}{c}4,21 \\
(3,48)\end{array}$ & 1 & $\begin{array}{c}0,57 \\
(0,52)\end{array}$ & 0 & 0,00 \\
\hline Bizonytalan & 6 & $\begin{array}{c}6,32 \\
(5,22)\end{array}$ & 2 & $\begin{array}{c}1,15 \\
(1,05)\end{array}$ & 0 & 0,00 \\
\hline Ismeretlen & 0 & 0,00 & 1 & $\begin{array}{c}0,57 \\
(0,52) \\
\end{array}$ & 1 & $\begin{array}{c}0,81 \\
(0,74) \\
\end{array}$ \\
\hline Összesen & 95 & 100,00 & 174 & 100,00 & 123 & 100,00 \\
\hline
\end{tabular}

17. táblázat: A jövevénynevek eredet szerinti megoszlása az egyes korszakokban az úrnők körében

\begin{tabular}{|c|c|c|c|c|c|c|}
\hline & \multicolumn{2}{|c|}{$\begin{array}{c}2 . \text { korszak } \\
(1283-1312)\end{array}$} & \multicolumn{2}{|c|}{$\begin{array}{c}\text { 1. korszak } \\
(1313-1342)\end{array}$} & \multicolumn{2}{|c|}{$\begin{array}{c}\text { 0. korszak } \\
(1343-1359)\end{array}$} \\
\hline & $\mathrm{db}$ & $\%$ & $\mathrm{db}$ & $\%$ & $\mathrm{db}$ & $\%$ \\
\hline Magyar & 10 & 21,28 & 6 & 13,95 & 4 & 13,79 \\
\hline Jövevény & 29 & 61,70 & 33 & 76,74 & 24 & 82,76 \\
\hline Bizonytalan & 2 & 4,26 & 2 & 4,65 & 1 & 3,45 \\
\hline Ismeretlen & 6 & 12,77 & 2 & 4,65 & 0 & 0,00 \\
\hline Összesen & 47 & 100,00 & 43 & 100,00 & 29 & 100,00 \\
\hline
\end{tabular}

18. táblázat: Az úrnők névféleségeinek eredet szerinti megoszlása az egyes korszakokban 


\begin{tabular}{|c|c|c|c|c|c|c|}
\hline & & $\begin{array}{l}\text { zak } \\
\text { 312) }\end{array}$ & & $\begin{array}{l}\text { zak } \\
\text { 342) }\end{array}$ & & $\begin{array}{l}\text { zak } \\
\text { 1359) }\end{array}$ \\
\hline & $\mathrm{db}$ & $\%$ & $\mathrm{db}$ & $\%$ & $\mathrm{db}$ & $\%$ \\
\hline Török & 0 & 0,00 & 0 & 0,00 & 0 & 0,00 \\
\hline Görög-latin & 20 & $\begin{array}{c}68,97 \\
(42,55) \\
\end{array}$ & 20 & $\begin{array}{c}60,61 \\
(46,51) \\
\end{array}$ & 16 & $\begin{array}{c}66,67 \\
(55,17)\end{array}$ \\
\hline Német & 5 & $\begin{array}{c}17,24 \\
(10,64) \\
\end{array}$ & 9 & $\begin{array}{c}27,27 \\
(20,93) \\
\end{array}$ & 5 & $\begin{array}{c}20,83 \\
(17,24) \\
\end{array}$ \\
\hline Szláv & 0 & 0,00 & 0 & 0,00 & 2 & $\begin{array}{c}8,33 \\
(6,90) \\
\end{array}$ \\
\hline Francia & 1 & $\begin{array}{c}3,45 \\
(2,13)\end{array}$ & 1 & $\begin{array}{c}3,03 \\
(2,33)\end{array}$ & 0 & 0,00 \\
\hline Bizonytalan & 3 & $\begin{array}{l}10,34 \\
(6,38)\end{array}$ & 2 & $\begin{array}{c}6,06 \\
(4,65)\end{array}$ & 0 & 0,00 \\
\hline Ismeretlen & 0 & 0,00 & 1 & $\begin{array}{c}3,03 \\
(2,33) \\
\end{array}$ & 1 & $\begin{array}{c}4,17 \\
(3,45) \\
\end{array}$ \\
\hline Összesen & 29 & 100,00 & 33 & 100,00 & 24 & 100,00 \\
\hline
\end{tabular}

19. táblázat: Az úrnők névféleségeinek eredet szerinti megoszlása a jövevényneveken belül az egyes korszakokban

Bár a magyar eredetű nevek arányában fokozatos csökkenést várnánk, az 1343-1359 közti korszakban az előzőhöz képest mérsékelt növekedést láthatunk. Ez lehet az adatok kis számából eredő torzítás is, ugyanakkor a névféleségek idôbeli változását vizsgálva (18-19. táblázat) kitűnik, hogy a tíz előfordulás mögött mindössze négy névegyed áll. Ráadásul ebből kettő csak egyszer fordul elő (1344: Viola [AO. 4: 442] és 1353: Rusa [AO. 6: 74-75]), így a másik kettő (3 Chala és 5 Sebe) nagyobb megterhelése, tehát feltehetőleg népszerú volta állhat a háttérben. Erre utal az is, hogy az úrnők névállománya mellett a Csala a jobbágyoknál, a Sebe pedig a polgároknál és a mezővárosiaknál is többször előfordul. Eszerint tehát nem arról van szó, hogy a magyar eredetû nevek újra kezdtek népszerűvé válni; az adatok csupán arról tanúskodnak, hogy egy-két népszerúbb magyar eredetú név - e csoport háttérbe szorulása ellenére - még a 14. század közepén is szélesebb körben használatos lehetett.

\subsection{A jövevénynevek változatai}

\subsubsection{A tárgyalt névváltozatok}

Az összesített, 1301-1359 közötti adatokat tartalmazó korpusz immár a névváltozatok átfogóbb vizsgálatára is lehetőséget nyújt. A következőkben ezért először 
közlöm a görög-latin eredetű egyházi alapneveknek, valamint a magyar névadási szokások szempontjából fontos más eredetű neveknek (a németből eredő Imré-nek és a szlávból átvett Lászlónak) azokat a változatait, amelyek előfordultak az egyesített korpuszban. Természetesen nemcsak a görög-latin eredetú, hanem más jövevénynevek is szerepelnek a korpuszban különféle változataikban, habár nem jelentős arányban. A Kunigunda például kizárólag változataiban fordul eló, melyek többsége a németben keletkezett (Kynge $\sim$ Kyngue $\sim$ Kunge, Genit $\sim$ Genith, Gene, Kolcha, Kuneeth, Kyngus; megítélésükhöz vö. BERRÁR 1949, 1952: 40). Ezek esetében azonban felmerülhet a lehetőség, hogy a scriptor azért nem az alapnevet jegyezte fel, mert nem tudván az adott vulgáris nyelven, nem ismerte fel az élőnyelvben használt változatnak az alapnévvel való összetartozását. Ráadásul jó részüket feltehetőleg nem magyar etnikumú személyek viselték (többük polgár); habár ennek bizonyítása eseti vizsgálatot igényelne, és sok esetben még így sem kapnánk megnyugtató választ. Ezért a későbbi vizsgálatok szempontjából biztosabbnak látszott ezeket kizárva csak az egész Magyarországon elterjedt és minden írástudó által ismert latin-görög eredetű nevekre koncentrálni. A két kivétel, az Imre és a László azért került be mégis a listába, mert igen korán elterjedtek az össznépességben, és a 14. században már ugyanolyan közismert és közhasználatú, ráadásul az Ârpád-házi szentek miatt (nem eredet, hanem etnikumbeli elterjedés alapján) tipikusan magyarnak minősíthető egyházi neveknek számítottak, mint a görög-latin eredetúek.

Címszóként a név latin változatát tüntetem fel, mivel az Imre és a László kivételével ezek a legvalószínúbb átvett alakok. Egyes nevek esetében persze számolnunk kell más nyelvi közvetítéssel, így a Mikelós világosan szláv vonásokat tükröz, sokszor azonban nem állapítható meg egyértelmúen az átadó nyelv. Ezért - bár az itt említett kivételek és megszorítások miatt a megnevezés nem tökéletes - jobb híján a következőkben tárgyalt egyházi nevek latin változatát nevezem alapnév-nek, összes vulgáris megfelelőjükre pedig (függetlenül azok nyelvi eredetétôl és keletkezésmódjától) együttesen a (név)változat terminust használom.

A listában tehát nem különítettem el egymástól sem a magyar és idegen nyelvú, sem a keletkezésmód szerint eltérő változatokat, hiszen ezek egyformán lényegesek abból a szempontból, hogy bennük az élő névhasználat írásbeli nyomaira ismerhetünk. A listában azokat a változatokat is feltüntetem, amelyek helynevekben fordultak elő (pl. 1358: Mortonspanlehotaya, AO. 7: 357). Ezeket azonban ritkítással megkülönböztetem a többi névváltozattól, mivel a későbbi, a változatok időbeli és társadalmi megoszlására irányuló vizsgálatban nem veszem őket figyelembe. A helynevek ugyanis feljegyzésüknél jóval korábban is keletkezhettek, ezért a számításba való bevonásuk torzíthatná az eredményeket.

A zárójelekben szereplő számok az előfordulás darabszámát jelzik. A szám nélküli változatok mindössze egyszer bukkantak fel a forrásaimban, a helynévben szereplő adatokat pedig pluszjellel adom meg. A listában - a helyesírási változatosság megfigyelhetősége érdekében - feltüntetem az ugyanazon változatot képviselő eltérő 
írásképeket is. A ,Marthon $\sim$ Marton $\sim$ Martun $\sim$ Morthon $\sim$ Mortun $(2+$ 10 Martun, 2 Marton, 1 Marthon, 1 Morton, 1 Mortun)" tehát azt jelenti, hogy e névváltozat ötféle, itt közölt írásváltozatára összesen tizenhét példa található az adatbázisban, ebből kettő egyénnévként, a többi pedig helynevek részeként, és az első három írásváltozat kizárólag helynévben fordult elő a korpuszban.

\section{Férfinevek:}

Abraham: Abram (9), Abych (2), Abrad, Abran, Abrank

Adam: Odun

Alexander: Sandor Sandur (16), Sank, Sanka

Amadeus: Made(us), Amade

Ambrosius: Ombreus

Andreas: Endre (12 + 1), Anda (6), Endere (3), Ender Endir (2), Andych (2), Endes (2), Andra, Anduch

Andronicus: Andornok Andornuk (3)

Anianus: Any as

Anthonius: Antal Antol (2), Anthus

Augustinus: $A g u s t u n$ (1)

Barnabas: Barrabas (25), Barlabas (4), Barla $(1+1)$, Barnolch, Baruch

Bartholomeus: Barthaleus $\sim$ Barthalus $\sim$ Barthalyus $\sim$ Bartholos $(4+1$ Bartaleus $)$, Bartal Barthal Bortol (3), Bartha (3), Berch, Berke, Burch, Byrtolom

Benedictus: Bene (7 + 1), Benche (7), Benke (6 + 1), Bench (5), Bense (4 + 1), Benk (3), Bend, Bende, B eneduk, Benkez.

Blasius: Balas $(12+1)$

Clemens: Kelemen $(1+2)$, Kecha, Keche $\sim$ Kyece (2), Kecheu

Damianus: Domian $(1+1)$, Dam a n, Demen, Dom a

Daniel: Danka, Danus

David: Dausa $\sim$ Dousa $\sim$ Dusa (3)

Demetrius: Deme (7), Denk (3), Demeter Demetur (2)

Desiderius: Deseu $\sim$ Desev $\sim$ Desew $\sim$ Dessew $(80+1$ D e seu $)$, Dese (1), Desk (1)

Dionysius: Dyenus (2), Denus, Dyen

Dominicus: Danch $\sim$ Donc $\sim$ Donch $\sim$ Donk $\sim$ Donz (21), Dama (2), Dacho, Dakou, Damakus, Douka

Egidius: Egud $\sim$ Egyd $\sim$ Egyed $\sim$ Egyud (4)

Emericus: Emuch $\sim$ Emvch $\sim$ Emuk (4), Emich, Em reh

Fabianus: Fabus, Fabian Fabyan (3)

Franciscus: Franchyle $\sim$ Francik $\sim$ Francyk (6), Franch $\sim$ Frank (5), Ferench (2)

Gabriel és Gabrianus: Gaab, Gebe, Gebech, Geburyen

Gallus: Gaal $\sim \mathrm{Gal}(4+1 \mathrm{Gal})$, Gochon 
Georgius: Geurk $\sim$ Gurk $\sim$ Gyurk Jurk $(12+2$ Gyurk $)$, Gurg $\sim$ Gurgh Gyurg $\sim$ Gyurgh Gyurgy (10), Gure Gurew Gyure Gywre (5), Gurke $\sim$ Gyurke (3)

Germanus: Garmanus Gyarman (2)

Gregorius: Geche Gueche (4), Gerew, Gerges, Geregur, Gergur, Gregor

Hadrianus: Adrean $\sim$ Adryan (3)

Ireneus: Erne $\sim$ Herne $(17+1$ E rne $)$, Irka, Irnusd

Jacobus: Jachou $\sim$ Jaco $\sim$ Jacou $\sim$ Jacow $\sim$ Jako $\sim$ Jakou Jakow Jakw $(16+1-1$ Jaco, Jako, Jakou), Jakch (5), Jekul Jekkul (5), Jacab I akap (2), Jakus $\sim$ Jacus $(1+1)$, Jaak, Jeklin

Joachim: Ivahun Iwabun (5), Iuahun ${ }^{6} \sim$ Juabun (2), Iwabim $\sim$ Iwabin (2), Jowachim

Johannes: Iuan $\sim$ Ivan $\sim$ Iwan $\sim$ Yuan $(60+2$ I uan, 2 Iwan, 2 Y uan), Ivanca $\sim$ Ivancha $\sim$ Ivanka $\sim$ Iwanca $\sim$ Iwanka $\sim$ Jvanka $\sim$ Ywancha $(58+2$ Iwanka $)$, Ihones $\sim$ Jhoenes $\sim$ Jhones $(10)$, Henneng $\sim$ Hennig $\sim$ Hennyg $\sim$ Hennyng $(8+2$ Henny g), Iuanca $\sim$ Joanca $\sim$ Johanca $\sim$ Johanka $\sim$ Juanka $(7)$, Hannos $\sim$ Hannus $\sim$ Hanus $\sim$ Honnus $(5+1$ Hanus), Iwanch $\sim$ Iwank (5), Janka $(3+2)$, Hanc Hanch $\sim$ Hanck $\sim$ Hank (4), Janus Y Yanus (3), Juan Junan (3), Gibaninus, Gyan (2), I wanus (2), Gaban, Gyank, Gybaan, Hank, Johan, Jones

Joseph: Isep $\sim$ Isyp (7), Josyp

Kilianus: Gylianus (5), Kelyan $\sim$ Kelyen (3), Gyelianus

Ladislaus: Lachk $\sim$ Lack $\sim$ Laczk $\sim$ Lazk $\sim$ Lochk (20), La zlou $\sim$ La zlov (5), Lacus (2), Laad, Lach, Lachou, Ladyk

Laurencius: Leucus $\sim$ Lenkes $\sim$ Lenkus $\sim$ Levkus $\sim$ Lewkus $\sim$ Lukus (30), Lenka $~$ Levka (3 + 1 Leuka), Leurench $\sim$ Leurinch (4), Leurente $\sim$ Leurenthe (2), Leuche, Luka

Lucachius: Luca $\sim$ Luka (14), Lucach $\sim$ Lukach (8), Lucas $\sim$ Lukas (3)

Marcellus: Marcel

Mark: Marcus $\sim$ Markus $^{8}$ (23)

Martinus: Marthon $\sim$ Marton $\sim$ Martun $\sim$ Morthon $\sim$ Mortun $(2+10$ Martun, 2 Marton, 1 Marthon, 1 Morton, 1 Mortun), Martonus Martunus $\sim$ Mortunus $(12+1$ Mortunus $)$

Matheus: Matheus $^{9} \sim$ Mathius $\sim$ Mathus $\sim$ Mathyus $\sim$ Matius $\sim$ Matthyus $\sim$ Matyus (24), Mathe $\sim$ Mathee (3 + 1 Mathee $)$, Mathenka Matyuka (3), Matha, Mathewo (rag.)

${ }^{6}$ Ivahun-nak is olvasható.

${ }^{7}$ Ivánká-nak is olvasható.

8 A függő esetben -us-ra végződőket számítottam ide.

${ }^{9}$ A függő esetben -us-ra végződőket számítottam ide. Mivel hét ilyen példa is előfordult, a ragozási hibánál valószínúbbnek tartom, hogy ez az alak is a Mátyus lejegyzése. 
Mauricius: Moroch $\sim$ Morouch $\sim$ Morowch $\sim$ Moruch $(5+$ Moruch $)$, Moric

Michael: Mibal Mibaly Mybaal Mybal (22), Myske (3), Michach Mychalch (3), Michcz Mykech (2), Myck, Mikche

Moyses: Mos $\sim$ Moys $\sim$ Moj̈s (13), Mayus $\sim$ Moius $\sim$ Moyus $\sim$ Moyws (10), Moyza

Nicolaus: Micho $\sim$ Michov $\sim$ Miko $\sim$ Myko $\sim$ Mykoh $\sim$ Mykou $\sim$ Mykow $(29+3$ Myko, 1 Micho, 1 Miko, 1 Mikou), Miche $\sim$ Mike $\sim$ Mikee $\sim$ Myke $\sim$ Mykew $(31+2$ Myke), Miclos $\sim$ Miklos $\sim$ Miklous $\sim$ Myclos $\sim$ Myklos $\sim$ Myklous (1+7 Miclos, 1 Miklos, 2 Myclos, 2 Myklos, 2 Myklous), Mykus $\sim$ Mykws (5 + 2 Mykus), Michocha $\sim$ Mykocha $\sim$ Mykotha (6), Kolos $\sim$ Koloz. $\sim$ Kolus (4), Myxe Myxse (3), Nyklinus Nyklynus (3), Michola Mykola (2), Mikouch Mykouch (2), Mycud Mykud (2), Niclin Nyclin (2), Koch Kolch (2), Mycoleth, Mykeche, Mykes, Mykolin, Nekekel, Nikalay

Paulus: Pausa $\sim$ Posa $\sim$ Pousa (21), Peous $\sim$ Pos $\sim$ Pous $\sim$ Pows $(17+1$ Po us $)$, Poka $\sim$ Pouca $\sim$ Pouka (16), Pal (7), Poch Pouch (6), Paul (4), Pocho Pochou (3), Ponya (3), Pachouch Packucz (2), Paulin Pawlin (2), Pothowcz. Potoch (2), Pael, Pala, Palus, Pok, Pool, Potow

Petrus: Peteu $\sim$ Petev $\sim$ Petew $\sim$ Petheu $\sim$ Pethev $\sim$ Pethew $\sim$ Petow (105), Pete $\sim$ Pethe $(14+1$ Pete, 2 Pethe), Peter $\sim$ Petur (15), Peterka $\sim$ Peterke $\sim$ Petirke $\sim$ Peturke $(4+1$ Peterke, 1 Petirke, 1 Peturke $)$, Petenye $\sim$ Pethene $\sim$ Pethyne (6), Petermanus $\sim$ Peturman $\sim$ Peturmanus $(3+1$ Peturm a n $)$, Peteuch $\sim$ Petheuch (3), Peder Pedur (2), Pese (2), Petres (2), Petrych Petryk (2), Pethych Petych (2), Peus, Pethk, Pethke, Pethus, Petichk, Petren

Philippus: Phile Phyle (5), Filpus Philpes Philpus $(3+1$ Filpus $)$, Philep $\sim$ Phylup (3), Philpe $\sim$ Phylpe (3)

Raphael: Raphaynus $\sim$ Ropheyn $\sim$ Rophin $\sim$ Rofoyn (4), Raph

Salamon: Salman, Sool

Samuel: Samyl

Saul: Sal(us) (2), Souka

Sebastianus: Sebe $(5+1)$, Sebus (3), Sebeuk Sebewk (2), Se b a sty a n

Seraphin: Serefyl $\sim$ Serephel $\sim$ Serephil (6), Serfel

Simon: Sinka $\sim$ Synka (7), Semeyn $\sim$ Semyen (2), Symonka, Synnie

Sixtus: Syge $\sim$ Syke (3), Sexe (2), Sykusd (2)

Stephanus: Chepan (31), Stephk Stepk (3), S teph an (3), Estphan, Tapan

Theodorus: Thyuadorius $\sim$ Thyuodor Tiodor (4), Thoka $\sim$ Thowka (2)

Thomas: Tamas Thamas Thomas (9), Tank Thonc Tonc (3), Tanka

Tiburcius: Thyba Tyba (16)

Timotheus: Thyma (3), Tymus

Valentinus: Valint

Vincentius: Bencenc $\sim$ Bencench $\sim$ Benchench $(7+1$ Benche nch $)$, Wynche

Vrbanus: Orban (2), Vrban 


\section{Női nevek:}

Agnes: Anglis (2), Agna, Aguch

Anna: Annus (8), Anich Anych (6), Anith Anyth (3), Anitha

Elisabeth: Els $\sim$ Elz (6), Els ebet $\sim$ Elzebeth (1+1), Else, Elys, E rse be th

Helena: Ilunch (5), Ilona Iluna Ilwna (4), Ila (2), Ilanch (2), Ilunka

Katherina: Kata $\sim$ Katha (11), Kathus $\sim$ Katus $\sim$ Kotus (8), Katalena $\sim$ Kathalena (2), Kathlen $\sim$ Kathlin $\sim$ Kathlyn (4), Kathow, Kathren, Katich, Katthre

Magdalena: Magich Magych Makych Mangich (5), Bagyth, Bogow, Magou

Margareta: Margit $\sim$ Margith $\sim$ Margyth (10), Margaleta, Margarita, Margita $(1+2)$

Maria: Marus (2)

Scolastica: Colys, Korustica

\subsubsection{A névváltozatok elhatárolásának problémái}

A fenti adatokat áttekintve jól látszik, hogy egyes változatok több alapnévből való levezethetősége gondot okozhat. Így a Dakou több $D a$ - kezdetű névből is származhat, a Mike, Mikó, Mikus stb. pedig a Mibály-ból és a Miklós-ból is eredhet.

Időnként az egyes változatok egymástól való elkülönítése is nehéz feladat. Ennek egyik oka a korabeli helyesírás variabilitásából eredő bizonytalanság. Igen valószínú például, hogy a Jachou ugyanúgy a Jákó írásváltozata, mint a Jaco, Jacou, Jacow, Jakoo, Jakou, Jakow és Jakw, vagyis a ch ebben az esetben a $k$ hang megfelelője, akárcsak a Michov esetében. Ezekben ugyanis a $k$ nemcsak képző, hanem az alapnév (Jacobus, illetve Jakab és Nicolaus, illetve Miklós) tövének a része is lehet, ráadásul e feltételezett hangalakot támogatja a fenti többi, megszokottabb íráskép is.

Ezzel szemben kérdéses lehet a Petrych olvasata, hiszen - $k$ és -cs képző egyaránt állhat a végén, viszont egyik olvasatban sem lehet a kérdéses mássalhangzó a tô része. Mivel azonban a forrásokban egy Petryk alak is felbukkan, ennek írásváltozataként tekintek rá, nem zárva ki azonban a Petrics olvasat lehetőségét sem. (Már csak azért sem, mert családnévként mindkettô létezik napjainkban: a 2007. január 1-jei állapotot mutató népesség-nyilvántartásban 376 Petrics és 1987 Petrik található.)

Hasonlóan kérdéses például a Danch $\sim$ Donc $\sim$ Donch $\sim$ Donk $\sim$ Donz (21) egymáshoz való viszonya is, hiszen a cs és a $k$ egyaránt szerepelhet és feltehetőleg szerepelt is képzőként. A Donz a Dancs $\sim$ Doncs német hatást tükröző lejegyzése lehet, a Danch, Donc és Donch viszont egyaránt tekinthető a Dancs $\sim$ Doncs és a Dank $\sim$ Donk írott változatának is. Elképzelhetô tehát, hogy e 21 példában nem egy, hanem két változat keveredik; ezek szétválogatása azonban pusztán az íráskép alapján nem lehetséges, ezért jobb híján alakváltozatokként tüntettem fel őket.

Ezzel szemben a Bench és Benk, valamint a Benche és Benke külön-külön változatokként vannak feltüntetve a listában, mivel előfordulásuk mennyisége nagyjából kiegyenlített, így ezekben véleményem szerint nagyobb valószínűséggel tarthatjuk a $c h$-t 
a [t] írásbeli megfelelöjének. Az a tény pedig, hogy a Bencs, a Bencse, a Benk és a Benke egyaránt létező családnevek napjainkban (vö. 2007-es népesség-nyilvántartás), igazolja mind a $c s$-s, mind a k-s névváltozatok ómagyar kori létezését. A korábbi példák alapján azonban természetesen nem zárhatjuk ki a Bench és Benche adatok Benk és Benke olvasatát sem.

Míg a fenti példák a képzők története szempontjából bírhatnak jelentőséggel, addig a Inanca olvasatának bizonytalansága hangtörténeti szempontból vet fel kérdéseket. A Johannes névnek ugyanis, mint láttuk fentebb, többféle Jo-/Ju- és $I$ - kezdetú változata is kialakult, ezért az adatok e hangváltozási tendencia bizonyítékaiként is figyelembe vehetők. Az említett Iuanca íráskép azonban mind Ivánka-ként, mind Juanka-ként vagy Juánka-ként olvasható, ráadásul mindkét olvasatot hitelesítő egyéb alakok is léteznek (pl. Iwanka és Juanka), így ismét nincs lehetôségünk az egyértelmú állásfoglalásra. Ugyanez mondható el a Joachim név változataként feltűnő Iuabun alakról is (vö. Iwahun és Juabun).

A helyesírási bizonytalanságok mellett a latin ragozás is eredményezhet kérdéses eseteket. Így a Matheus függő esetben is előfordult; ez egy-két esetben lehet nyelvtani hiba, mivel azonban hét ilyen példa is elófordult, valószínúbbnek tartom, hogy ez az alak a Matbius-hoz hasonlóan a Matheus alakváltozataként kialakult Mátyus lejegyzése lehet. Hasonló döntés elé állít bennünket a Marcus és Markus alak is. Bár az előbbi megfelel a név klasszikus latin alakjának, az oklevelek többségében inkább a Mark alakkal talákozunk: ez tekinthető a név tipikus standardizált változatának a középkori magyarországi latinságban. Mindezek következtében a függô esetet igénylő pozícióban szereplő Marcus és Markus inkább a Márkus változat lejegyzése lehet.

Szintén a ragozás eredményezhet kétféle értelmezési lehetőséget az Endere kapcsán, bár az előzőkkel ellentétben itt nem a latin, hanem a magyar nyelv szempontjából. Az említett változat ugyanis kizárólag apanévi szerepben túnik fel a személyjelölő szerkezetekben, ezért a végén álló -e akár az -é patronimikumképző is lehet. Ilyetén módon való értelmezését támaszthatja alá az Ender alak létezése, valamint a Scolastica filia Balase (1346, AO. 4: 621) típusú szerkezetek is, melyekben a latin Blasius név magyar Balas változata szintén -é patronimikumképzővel áll. (Az efféle, latinmagyar hibrid szerkezetekről a későbbiekben még részletesebben szólok majd a 3.2.2.2.2. fejezetben.) Csakhogy az ÁSznt. (284-285) számos nominativusi példát közöl az Endere és Endereh alakra is, ennek korabeli létezését tehát szintén nem vonhatjuk kétségbe. Így ismét nem maradt fogódzónk annak eldöntésére, hogy az egyes Ender és Endere adatok egy vagy két változatnak tekintendők-e. Mindenesetre a fenti listában külön kezeltem őket, hiszen mint láttuk, mindkét változat létezésére van bizonyíték. 


\subsubsection{A névváltozatok oklevélbeli arányának időbeli változása}

Az 1301-1342 közötti oklevelekben szereplő változatok áttekintése során már megállapítottam, hogy az Árpád-korihoz képest feltűnően kevesebb a névváltozatok mennyisége. Mivel az ÁSznt. nem közli az összes névadatot, amely a feldolgozott forrásokban előfordult, az Árpád-kori korpuszon nem lehet megvizsgálni, hogy e források milyen arányban tartalmaztak a nevek latin változatával szemben valamilyen vulgáris nyelvi változatot. Saját korpuszom azonban lehetőséget nyújt egy efféle vizsgálatra, így legalább közvetett bizonyítékot nyerhetünk belőlük a fenti állítás helyességének ellenőrzésére.

A 3. ábráról, mely a fenti összes névváltozatnak az adott nevek összes (latin alapalakban és vulgáris nyelvű változatban együttesen való) előfordulásához viszonyított az arányát, illetve annak időbeli változását mutatja, világosan leolvasható, hogy a férfiak megnevezésében a 14. század elejétől kezdve (a 10-es évek enyhe növekedésétól eltekintve) fokozatosan csökkenő mértékben vannak jelen a vulgáris nyelvi változatok: az Árpád-kor végi 15\%-hoz képest az Anjou-kor hatodik évtizedére megfeleződött az arányuk.

Ezt az eredményt kétféleképpen is magyarázhatjuk. Egyrészt tükrözheti ez a kép a standardizálás növekedését, illetve általánosabbá válását az oklevélírásban. Eszerint az oklevelek írói egyre tudatosabban törekedhettek arra, hogy az élőnyelvi névváltozatok helyett a név latin alapalakját tüntessék fel a dokumentumokban. Másrészt arra is utalhat ez az eloszlás, hogy a férfinevek egyes vulgáris változatai fokozatosan kikoptak a használatból, vagyis a forrásokbeli aránycsökkenés az élőnyelvi arányuk csökkenését tükrözi vissza. Bár úgy vélem, jelenlegi ismereteink alapján egyik magyarázat sem zárható ki, bizonyos szempontokat figyelembe véve mégis inkább az utóbbit tartom valószínűbbnek. Azt tudjuk ugyanis, hogy az írnokok tudatosan törekedtek a nevek standardizációjára, de milyen egyéb adat támaszthatja alá azt, hogy e törekvés mértéke időben éppen ilyen módon változott? A személyjelölő szerkezetek nyelvének a vizsgálata (l. később, az élőnyelvi névhasználat oklevélbeli beszưrődése, a névfordítás és a többnyelvűség kérdéskörei kapcsán) inkább arra szolgáltat bizonyítékokat, hogy az élőnyelvi névhasználat hogyan jelenik meg az oklevelekben a standardizációs törekvés ellenében. Mivel azonban itt csak szórványos esetekről van szó, ezeknek az összes szerkezethez viszonyított arányából semmiféle következtetés nem vonható le a jelenség időbeli változására vonatkozólag. Az ugyanakkor bizonyos, hogy a férfinevek fenti változatainak többsége nem maradt fenn napjainkig keresztnévként, legfeljebb családnevekben vagy helynevekben éltek tovább. Ez a tény, valamint az egyes alapnevekhez tartozó változatok számának csökkenése együttesen azt a magyarázatot támasztják alá, amely szerint a görbe a névváltozatok élőnyelvbeli használatának gyengülését mutatja. 


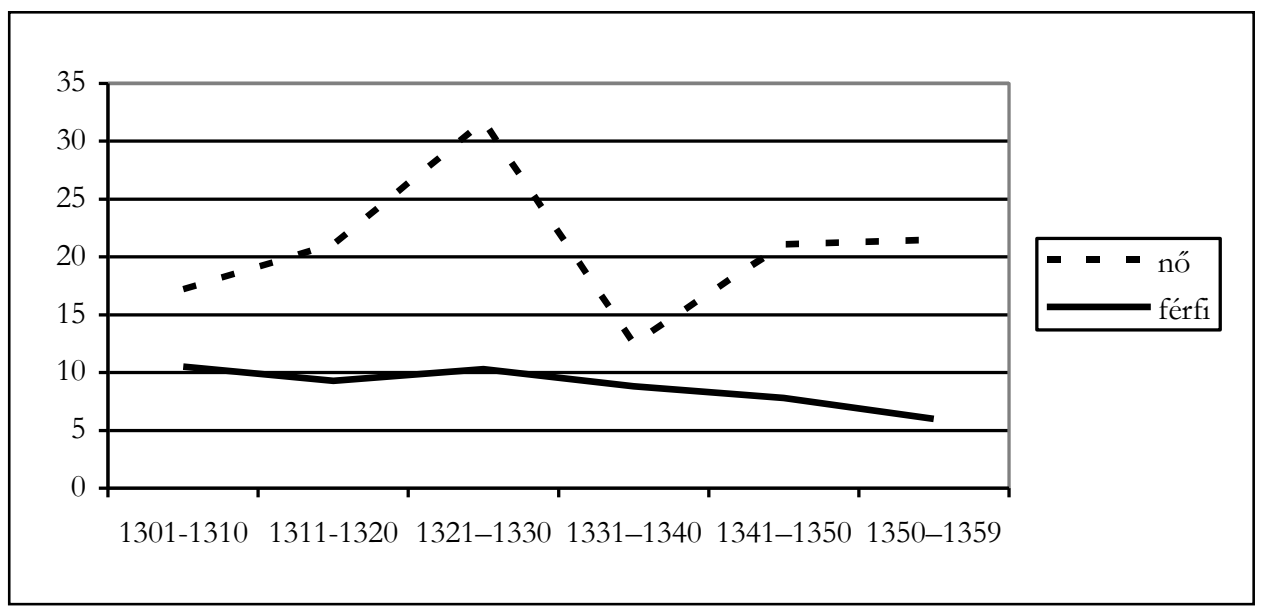

3. ábra: A vulgáris névváltozatok előfordulási arányának alakulása az egyesített korpuszban

A női névváltozatok görbéjének szeszélyessége ezzel szemben inkább az adathiányból fakadó torzításnak tudható be, hiszen míg a férfinevek esetében az első évtized 978 adatától eltekintve 1000 fölötti, az utolsó évtizedre pedig már több mint 4000 adathoz viszonyíthatjuk a névváltozatok számát, addig a nőknél csak az utolsó előtti évtizedben emelkedik 100 fölé a teljes adatmennyiség, és az utolsó évtizedben is alig haladja meg a 200-at.

Azt ugyanakkor e görbe alapján is viszonylagos biztonsággal állíthatjuk, hogy a női nevek változatai végig magasabb arányban kerültek be az oklevelekbe, mint a férfinevekéi. Erre szintén több magyarázatot találhatunk, melyek azonban a férfinevek kapcsán tapasztaltakkal ellentétben nem kioltják, hanem inkább erősítik egymást. Az egyik ok az lehet, hogy a középkori egyházi névkincs szegényebb volt női nevekben, mint férfinevekben, ennélfogva nagyobb lehetett az egyes nevek megterheltsége. Ezt elvileg alátámaszthatja a 11. táblázat is, mely a férfinevekéhez képest (1. táblázat) némileg magasabb megterheltségről árulkodik; a kis adatmennyiség okozta torzítás miatt azonban ezeket a számokat nem fogadhatjuk el kétségtelen bizonyítékként. A másik lehetséges magyarázat a nők korabeli, alárendelt társadalmi szerepében keresendő: mivel jogi szempontból kevésbé voltak fontos szereplők, nevük feljegyzésére kevesebb gondot fordíthattak, azaz kevésbé érvényesíthették a standardizáló törekvéseket. A harmadik magyarázat valójában inkább egy felvetés: lehetséges-e, hogy a női nevekben szereplő képzők tovább őrizték becéző funkciójukat, mint a férfinevekben? Azt már többen is hangsúlyozták, s korábban magam is számos példán bemutattam (vö. pl. RÁCZ 1956a, 1956b: 50, 1960: 148; PAPP 1958: 454; B. LŐRINCZY 1962: 30-33; SZÉKELY 1970: 203; KOROMPAY 1980: 521; FEHÉRTÓI 1997: 73; SLÍZ 2011b: 55; TÓTH 2013: 243), hogy a férfinevek változatai - legalábbis a 
kései ómagyar korra - már nem (vagy hihetőbben, hiszen a becézés szükséglete nyilván nem szűnt meg: nem kizárólagosan) becéző funkciót hordoztak. A női szerepből kiindulva talán nem teljesen alaptalan az a feltevés, hogy az alacsonyabb társadalmi szerepet betöltő, gyengébbnek tartott nem esetében ez a becéző funkció erősebben érvényesülhetett. Talán ennek köszönhető az a jelenség is, amelyre már korábban is felhívtam a figyelmet (vö. SLíz 2011b: 134): míg a férfinevek fenti változatainak többsége mára becézőnévként sem él, addig a fenti női névváltozatok jó része ma is használatos becézésre.

\subsubsection{A névváltozatok oklevélbeli arányának társadalmi megoszlása}

A névváltozatok kapcsán többen is felvetették, hogy oklevélbeli előfordulásuk aránya összefüggésben lehet a névviselők társadalmi helyzetével, valamint a latin alapalak presztízsével, illetve (a kor fogalmaihoz mérten) hivatalos jellegével. BERRÁR JOLÁN (1952: 53) például megállapította, hogy a női jövevénynevek változataival megnevezettek között nagyobb arányban fordultak elő szolgálók, mint úrnők, mivel a szolganevek feljegyzésére, latinosítására kisebb figyelmet fordítottak a scriptorok, inkább a valóban használt névalakot illesztették be az oklevélbe. TÓTH VALÉRIA (2007: 410-411) a Stephanus latin alapnév és a Chepan névváltozat Árpád-kori társadalmi megoszlása alapján jutott hasonló következtetésre, majd később, immár általános érvénnyel kiterjesztve a következőt írja: „Azt is valószínűsíteni lehet továbbá, hogy az alacsonyabb társadalmi állásúak pontos rögzítésére nem fordítottak annyi gondot a szkriptorok, mint a felsőbb körökhöz tartozókéra, ezért a róluk szóló feljegyzések gyakrabban is őriznek magyar nyelvú névformákat. A latinosítás eszközét az oklevélírók a felsőbb rétegbeliek nevesítésekor ugyanakkor szinte kötelező érvénnyel használják." (TÓTH 2013: 39.)

A kérdést immár az egyesített korpusz férfinevei alapján ${ }^{10}$ áttekintve az előző fejezetben bemutatott módszert alkalmaztam, vagyis az összes listázott névváltozatnak a szóban forgó nevek összes (latin alapalakban és vulgáris nyelvú változatban egyaránt figyelembe vett) előfordulásához viszonyított arányát ez esetben társadalmi rétegekre vetítve ábrázoltam (4. ábra).

Ez alapján a fenti véleményekkel ellentétben az a kép rajzolódik ki, hogy - legalábbis ebben az idôszakban - nincsen jelentős különbség az egyes rétegek között a névváltozatok oklevélbeli előfordulásának arányát tekintve. Különösen, ha figyelembe vesszük az adatmennyiség nagyságrendi különbségeiből eredő erős torzítást. ${ }^{11}$

\footnotetext{
10 A női nevek korpuszának kis elemszáma, különösen ami az alacsonyabb rétegeket illeti, nem teszi lehetővé a vizsgálatot.

${ }^{11}$ Míg a nemesek esetében az összes előfordulás közel tízezer (9933), addig a többi rétegben mindössze 200-700 közötti adatmennyiséggel számolhatunk. Azaz a nemesség körében
} 


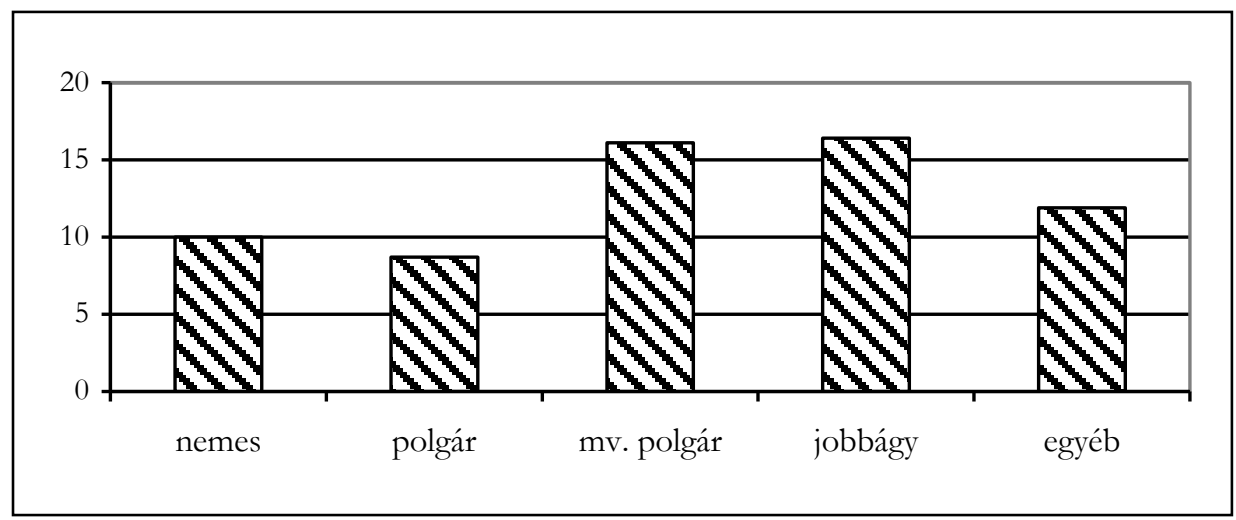

4. ábra: A listázott névváltozatoknak a szóban forgó nevek összes előfordulásához viszonyított aránya társadalmi rétegek szerint

Korábban, az 1301-1342 közötti korpusz áttekintésekor egy másik módszerrel is hasonló eredményre jutottam: a Johannes és a Petrus vulgáris változatai között megvizsgálva a nemesek arányát azt tapasztaltam, hogy az előbbi név változatait viselők között a nemesek az összes többi rétegnél együttesen is nagyobb arányban voltak jelen, az utóbbi esetében viszont a másik négy réteg együttes aránya meghaladta a nemesekét (vö. SLíz 2011b: 137). Ez - a fenti vizsgálat eredményével együtt - arra utal, hogy a névváltozatok oklevélbe kerülését pusztán a presztízzsel és a társadalmi különbségekkel magyarázni - habár e két tényező szerepe nyilván nem vonható kétségbe - túlzott leegyszerűsítés, illetve általánosítás lenne. Úgy vélem ugyanis, hogy az oklevelekbe bekerült vulgáris változatok társadalmi rétegek közötti megoszlása nevenként eltérő. Ennek igazolására összevetettem néhány, az összes előfordulást tekintve jelentősebb számú névváltozattal rendelkező név változatainak a társadalmi megoszlását, összehasonlítva ezt a társadalmi rétegeknek a tárgyalt összes névváltozatból való részesedésével (20. táblázat).

A nemesek adatai (999 előfordulás) az összes névváltozat (1227 előfordulás) 81\%-át teszik ki. Mint látjuk, egyes nevek változatainak összes előfordulásából ennél nagyobb mértékben részesednek (pl. Desiderius, Ladislaus, Stephanus, Lucachius), vagyis e neveket a nemességhez tartozók esetében nagyobb arányban jegyezték fel változatokban, mint az összes többi rétegben együttvéve. Más nevek esetében viszont kisebb arányban képviseltetik magukat a változatok között, mint a többi réteg együttesen.

1\%-os eltéréshez 99 adat szükséges, a legkisebb elemszámú (205) kategóriát alkotó mezővárosiaknál viszont már 2 adat is elegendő. 


\begin{tabular}{|c|c|}
\hline Név & Nemesek aránya (\%) \\
\hline Desiderius & 98 \\
\hline Ladislaus & 96 \\
\hline Stephanus & 88 \\
\hline Lucachius & 84 \\
\hline \hline Jacobus & 80 \\
\hline Matheus & 77 \\
\hline Dominicus & 76 \\
\hline Petrus & 74 \\
\hline Benedictus & 60 \\
\hline
\end{tabular}

20. táblázat: A nemesek aránya egyes nevek névváltozatainak összes előfordulása között

Ezen eltérések mögött számos tényező húzódhat meg. Ezek egyike lehet a név adott rétegbeli népszerűsége: így például a Desiderius alapnév 80 adata között mindössze egy jobbágy és egy mezôvárosi polgár fordul elő, a többi 78 adat nemesek neveként szerepel; a Ladislaus (változataival együtt) a nemesség körében az 5. pozíciót foglalja el a leggyakoribb nevek között, míg a mezővárosiaknál csupán a 8., a jobbágyoknál pedig csak a 10. helyen áll; a Benedictus ezzel szemben a jobbágyoknál mutatkozik népszerúbbnek (9.), a mezővárosiaknál 12., a nemeseknél pedig csak a 15. (vö. 1. táblázat). További fontos tényező lehet az is, hogy az egyes változatoknak a latin alapnévvel való összefüggése mennyire élénken élhetett még a scriptorok tudatában. Az eddigi, általános áttekintést követően ezért a továbbiakban az egyedi, csak bizonyos nevekre jellemző jelenségekre irányítom a figyelmemet.

\subsubsection{Latin alapnevek és vulgáris változataik összefüggése: egyedi jellemzők}

Az egyes névváltozatokat áttekintve azt tapasztaljuk, hogy míg egyes latin alapneveknek a mai magyar megfelelöjükkel egyező változatai fel-felbukkannak a források személyjelölő szerkezeteiben, sőt egyes nevek esetében viszonylag nagy számban kerülnek elő (pl. Margit, Sándor), addig másoknál csupán a személyneveket tartalmazó helynevekben találkozunk ezekkel a változatokkal. Ez még a legnépszerúbb nevekre is igaz; így a személynévi adatok között a János, Jakab, László, Lórinc, Mihály, Tamás stb. változatok egyetlen adata sem lelhető fel személyneves korpuszomban, a helynevekben azonban rendre feltünnek: 1344: Zenthlazlou (AO. 4: 443), 1350: Nogjanusfeldy 
(AO. 5: 416), 1352: Zentmibal (AO. 5: 587), 1353: Jacabfolua (AO. 6: 103), 1356: Tamastelke (AO. 6: 491), 1357: Zenth-Leurinch (AO. 6: 538). Ez azért is feltűnő, mert a személynévi korpuszból hiányzó, ma anyakönyvezhető keresztnévként használt változatok többsége az ÁSznt. tanúsága szerint már az Árpád-korban is biztosan létezett, sőt némelyikükről viszonylag jelentős mennyiségú adat maradt fenn. Így a János írásváltozatai (Ianos, Ianus stb.) több mint két hasábot töltenek meg (ÁSznt. 404-405), a Mihály-é másfelet (ÁSznt. 542-543), sőt a Margit-ra is van már adat a 13. századból (ÁSznt. 517, Margith alcímszó a.). Bár például a Jakab és a Lászlló változatokkal nem találkozunk az Árpád-kori anyagban, a fentieket látva hiányuk nagyobb valószínúséggel a véletlennek tudható be (fel nem jegyzés, források pusztulása stb.). Kevéssé képzelhető el ugyanis, hogy e változatok csak későn, a 14. században jöttek létre különösen, ha figyelembe vesszük a névváltozatok arányának korabeli, folyamatos csökkenését.

Már a korpusz első felének az elemzésekor kirajzolódott az a kép, amely szerint a leggyakoribb neveknek általában több változatuk van (SLíz 2011b: 132-134). Ez azonban, mint már akkor is látható volt, nem általánosítható megállapítás, hiszen például a gyakori Demetrius-nak mindössze két változata kerül elô, miközben a jóval ritkább Saul-nak vagy Sixtus-nak is több változatával számolhatunk. Ráadásul egyes nevek esetében nagyságrendi eltérések vannak az egyes változatok megterheltsége között. Ezek a különbségek az 1343-1359 közötti időszak okleveleivel kiegészülve még nyilvánvalóbban kiütköznek: míg a Benedictus változatai viszonylag kiegyenlítetten fordulnak elő, addig a szintén sok változattal rendelkező Johannes esetében az Iván és Ivánka, a Ladislaus esetében a Lack, a Laurencius-nál a Lókös, a Petrus-nál a Petôs stb. elsöprő fölényben van a többi változattal szemben. Gondolhatnánk, hogy ezek kiemelkedése a többi közül már az alapnévtôl való elszakadásukat jelzi, az alapnévvel és névváltozattal egyaránt jelölt személyek számos, korábban már említett példája (pl. SLíz 2011b: 53-54) azonban ellentmond ennek, ahogyan az is, hogy e változatok végül többnyire nem maradtak fenn önálló keresztnévként.

Az alapnévtől való elszakadás kérdése kapcsán azt is érdemes kiemelni, hogy a korpuszban olyan helynevek is előfordulnak, amelyeknek többszöri lejegyzései ugyanazon latin alapnév eltérô változatait örökítették meg: Domahyda (1334, AO. 3: 89) és Damanhyda (1337, AO. 3: 334), Myketeleke és Mykusteleke (1355, AO. 6: 317-318, ugyanazon oklevélben). Ezeknek azért is van különleges jelentőségük, mert - mint az 1301-1342 közötti korpusz elemzésekor jeleztem (SLÍZ 2011b: 55) a személynévi adatok között bőven van példa arra, hogy egy személyt egyszer a latin alapnévvel, máskor valamely névváltozattal jelölnek meg az oklevelekben, arra viszont nemigen találni adatot, hogy ugyanazon személyt az alapnév két különböző változatával jelölték meg. Akkor ezt a hiányt úgy értelmeztem, hogy az adott személyt az élőnyelvben feltehetőleg mindig az adott, már erősen (bár még nem teljesen) önállósult névváltozattal (pl. Petố) nevezték meg, a scriptor azonban még tisztában lehetett e változatnak az alapnévhez való tartozásával, ezért is tudta Petrus-ként 
standardizálni adandó alkalommal. A fenti, helynévi adatok viszont arról árulkodnak, hogy mégsem erról lehetett szó, legalábbis nem minden esetben: ezek ugyanis azt tükrözik, hogy a névhasználók egyértelmúen tudatában voltak a két változat közös eredetének, ennélfogva felcserélhetőnek tartották őket. Ez pedig arra enged következtetni, hogy a legtöbb névváltozat önállósága kisebb lehetett a korábban feltételezettnél.

Érdekes ugyanakkor, hogy vannak olyan nevek, amelyek jellemzőbben fordulnak elő egy vagy több változatban, mint latin alakjukban. Ilyen a férfinevek közül a Desiderius, amelynek latin alapalakjával egyszer sem találkozni a korpuszban; az Ireneus, amelynek huszonhárom adatából mindössze három a latin; vagy a Vincentius, melynek tizenegy adatából csak kettő szerepel latinul. A nőknél hasonlót tapasztalunk a Magdalena esetében, amely kilencból csupán egyszer szerepel latinul.

Ezzel szemben egyes neveknek egyáltalán nem alakult ki, vagy legalábbis az oklevelekben nem szerepel vulgáris nyelvi változatuk (pl. Clara), vagy csak igen ritkán fordulnak elő az oklevelekben vulgáris nyelvi változatban (pl. a 34 Fabianus mellett mindössze egy Fabus található a korpuszban, és a 45 Valentinus-szal szemben is csupán egyetlen $V$ alint áll). Ez is azt mutatja, hogy a névváltozatok önállóságának fokát nemigen lehet egységesen megállapítani: nyilván voltak olyanok, amelyek már erősebben eltávolodhattak latin megfelelöjüktől (pl. a Dęsóa a Desiderius-tól, ahogyan arra TóTH VALÉRIA is utalt; vö. 2015: 445), míg másoknak a latin alapnevükkel való összetartozása még élénkebben élhetett az írástudók tudatában.

Már az első, 1301-1342 közötti korpuszban is több idegen eredetú névváltozat fordult elő; az újabb gyújtés számos további, túlnyomórészt német változatot, illetve a korábban már látott változatokra újabb adatokat hozott felszínre (pl. német Jekul, Jeklin, Nyklyn; Anglis, Els, Katbren). A névváltozatok teljes listája alapján jól látható, hogy elsősorban a legnépszerúbb, Európa-szerte elterjedt, a magyar névállományban is az Árpád-kor kezdete óta jelen lévô nevek esetében találkozunk ilyen változatokkal (pl. Jacobus, Johannes, Nicolaus; Elisabeth, Katharina). Az is megfigyelhető ugyanakkor, hogy a 14. században Magyarországon még viszonylag újnak és éppen ezért ritkának számító Franciscus a latin mellett még többségében idegen eredetú változatban jelenik meg az oklevelekben: a 25 előfordulás között 11 idegen nyelvú és mindössze 2 magyar változat található (a maradék 12 említés a latin alapnévvel történt), bár viselóik többsége esetében nem mutatható ki német származás vagy kapcsolat.

Végezetül érdemes megemlíteni, hogy van egy névváltozat, amelynek használata mintha következetességre utalna: a Blasius latin alapnév magyar Balas változata ugyanis kizárólag apanévi szerepben túnik fel, pl. 1347: Simon filius B a la se (AO. 5: 87), 1353: Thome filii B a la sey (AO. 6: 47). Ez alapján felmerülhet a gyanú, hogy e megkülönböztetés funkciója a névelem családnév voltának kifejezése lehetett. Ezt az a tény is alátámaszthatná, hogy a 16. század elején, amikor már igazolhatóan léteztek családnevek, a veszprémi urbáriumban (1524) a keresztneveket továbbra is a standard latin változatukban, az egyénnévből keletkezett családneveket viszont már 
következetesen vulgáris nyelven jegyezték fel; 1. pl. 1324: Benedictus Myklos (VeszprUrb. 108), Michael Ke lemen (VeszprUrb. 110). Ezt a korszakot azonban több mint 150 év választja el a vizsgált periódustól, és ez a különbség a családnevek kialakulásának időszakában hatalmasnak számít. Ráadásul a források típusa is eltér, hiszen a korpuszom nem összeírásokra, hanem jórészt birtokügyekkel kapcsolatos oklevelekre épül; a későbbiekben pedig, a 3.1. fejezetben látni fogjuk, hogy a forrástípus alapvetően befolyásolja a személyjelölő szerkezetek felépítését. Ezért a 16. századi adatok legfeljebb egyéb érvekkel megtámogatva fogadhatók el analógiaként.

A meglévő bizonyítékok azonban ezekkel éppen ellentétes irányba mutatnak. A veszprémi urbárium neveinek nyelvi alkatából kiindulva ugyanis nem az a lényeg, hogy a Balas minden esetben apanévi funkcióban fordul elő, hanem éppen ellenkezőleg: azt kellene igazolnunk, hogy apanévként kizárólag e változatban szerepelt. Az adatok azonban ellentmondanak ennek: 1353: Lucasfilius Blasii (AO. 6: 76), 1358: Benedictus filius B las ii de Lackowch (AO. 7: 419) stb.

A másik érv a nők korabeli írásbeli megjelölésének vizsgálatából fakad. Mint az 1301-1342 közötti korpusz alapján kimutattam (és ezt az egyesített korpusz adatai is megerősítik), a nőket a korszakban valamely férfirokonukhoz viszonyítva, körülírással nevezték meg; a korpuszban egyetlen, nőre vonatkozó családnév sem található (vö. Suíz 2011b: 222). Ezért a Scolastica fili a B a la se de Pechwl (1346, AO. 4: 621) adatban a Balase nemigen lehet családnév.

Meggondolandó továbbá, hogy a korpusz egyetlen neve esetében sem tapasztalhatunk hasonló mintázatot a latin alapnév és egy vagy több vulgáris változat használatában. Mindezek alapján az tűnik a legvalószínúbb magyarázatnak, hogy a Balas és a Blasius funkcionálisnak tűnő megoszlása valójában nem annyira az oklevélírók következetességének, mint inkább a véletlennek a múve.

\subsubsection{Egyes névváltozatok hasznosíthatósága a jo-/ju- > i- változás vizsgálatában}

A névváltozatok elkülöníthetősége kapcsán már utaltam arra, hogy a Johannes, a Joachim és a Joseph magyar változatai között $J o$ - /Ju- és $I$ - kezdetúek egyaránt vannak, s ezek alkalmasak lehetnek e hangváltozás korabeli területi elterjedtségének a feltárására. ${ }^{12}$ Hasonló célú névföldrajzi vizsgálatot végzett néhány éve HEGEDŰs ATTILA (2010) helynevek történeti adatai, VÖRÖS FERENC (2010, 2011b) pedig a Juhász és Ihász családnevek szinkrón névföldrajza alapján. Mindketten arra a következtetésre jutottak, hogy a változás határa nagyjából a Duna vonaláig terjedhetett: az $i$-s változatok

12 Sơt BERRÁR JOLÁN a Johanna név Iwanya változatára is talált egy példát 1381-ből (BERRÁR 1952: 37). 
a Dunántúlon és északon voltak jellemzőbbek. A következőkben arra keresem a választ, hogy a fenti három latin alapnév korpuszomban szereplő, a kérdés szempontjából releváns változatai szintén alátámasztják-e ezt a megfigyelést.

$\mathrm{Az}$ eredmény megfelelő értelmezéséhez elengedhetetlen néhány módszertani kérdés tisztázása. Ezek közül az első a névadatok nyújtotta lehetőségek felvázolása, másképpen szólva az adott vizsgálatban alkalmazható szűkebb korpusz behatárolása. Hiába áll ugyanis rendelkezésünkre a korpusz leggyakoribb nevének több ezer adata, a latin alakok (Johannes) jelen esetben természetesen nem használhatók fel. Szintén kizártam azokat az alakokat, amelyek $j$-vel és $i$-vel is olvashatók (pl. Iuanka), csak az egyértelmű adatokat véve figyelembe. Elvben érdemes lett volna mind a $j$-s, mind az $i$-s kezdetű változatok megoszlását térképre vetíteni, az előbbiből azonban annyira kevés van a korpuszban, hogy eloszlásuk semmiféle értékelhetô eredményt nem mutatott volna. Ezért kizárólag az $i$-s változatokat vettem figyelembe, nem téve semmi egyéb különbséget az egyes nevek, illetve változatok között.

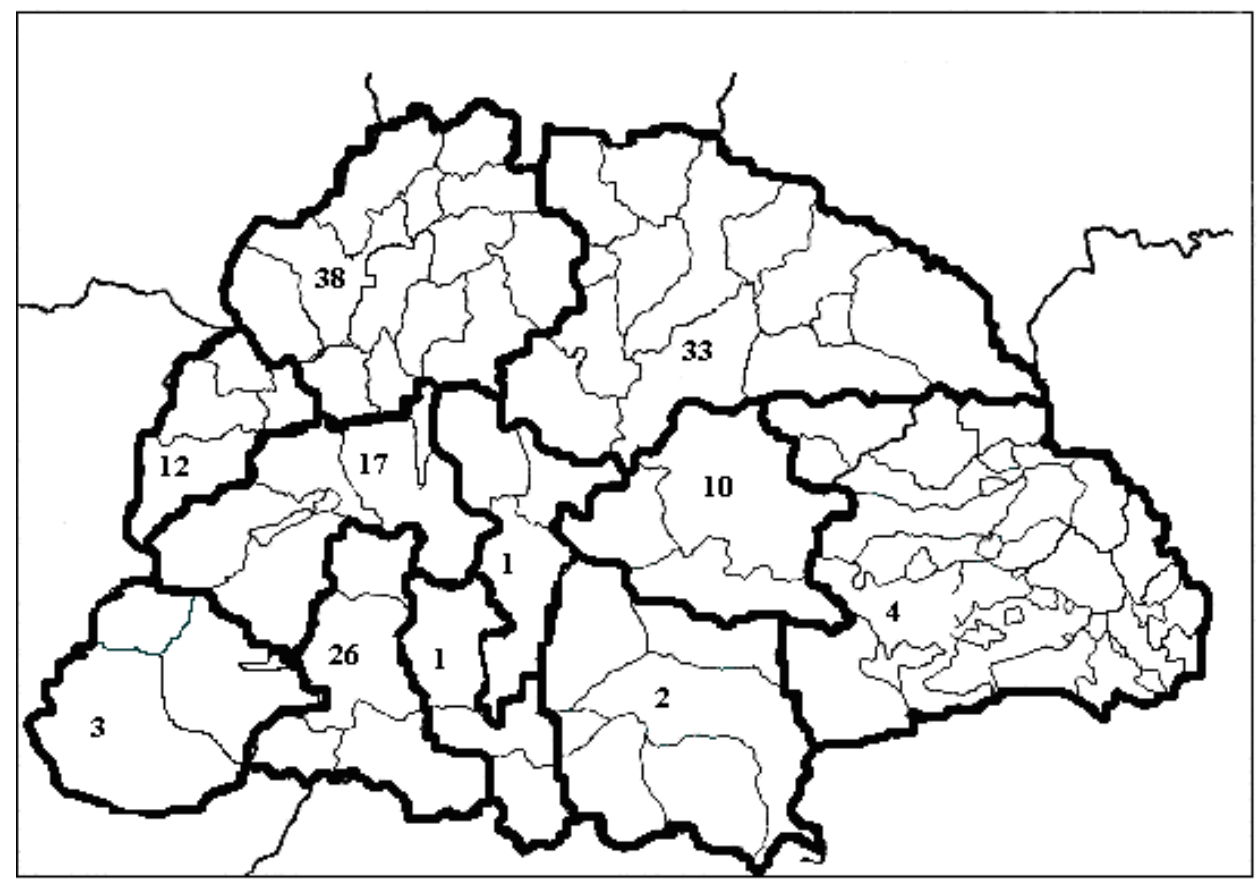

5. ábra: A Johannes, Joachim és Joseph i- kezdetű változatainak földrajzi megoszlása

Az így kirajzolódó kép az adatok fennmaradásának esetlegessége mellett azért sem lehet teljes, mert nem tudhatjuk, hogy a számtalan standardizált alak mögött hány élőnyelvi $i$-s változat rejtőzik. A feldolgozás során emiatt kénytelenségből 
darabszámmal dolgoztam, hiszen az adatok mennyiségét nem volt mihez viszonyítani. Így csupán azt tudjuk megfigyelni, hogy az egyes vidékeken egymáshoz képest milyen arányban vannak jelen az $i$-s változatok. Ami az adatok térképre vetítését illeti, a Pt. felhasználása miatt, az egyházmegyékkel való összevethetőség érdekében ismét az 1301-1342-es adatbázis feldolgozása során alkalmazott, több megyét magukba foglaló régiókkal dolgoztam (erről bôvebben l. SLíz 2011b: 39-40).

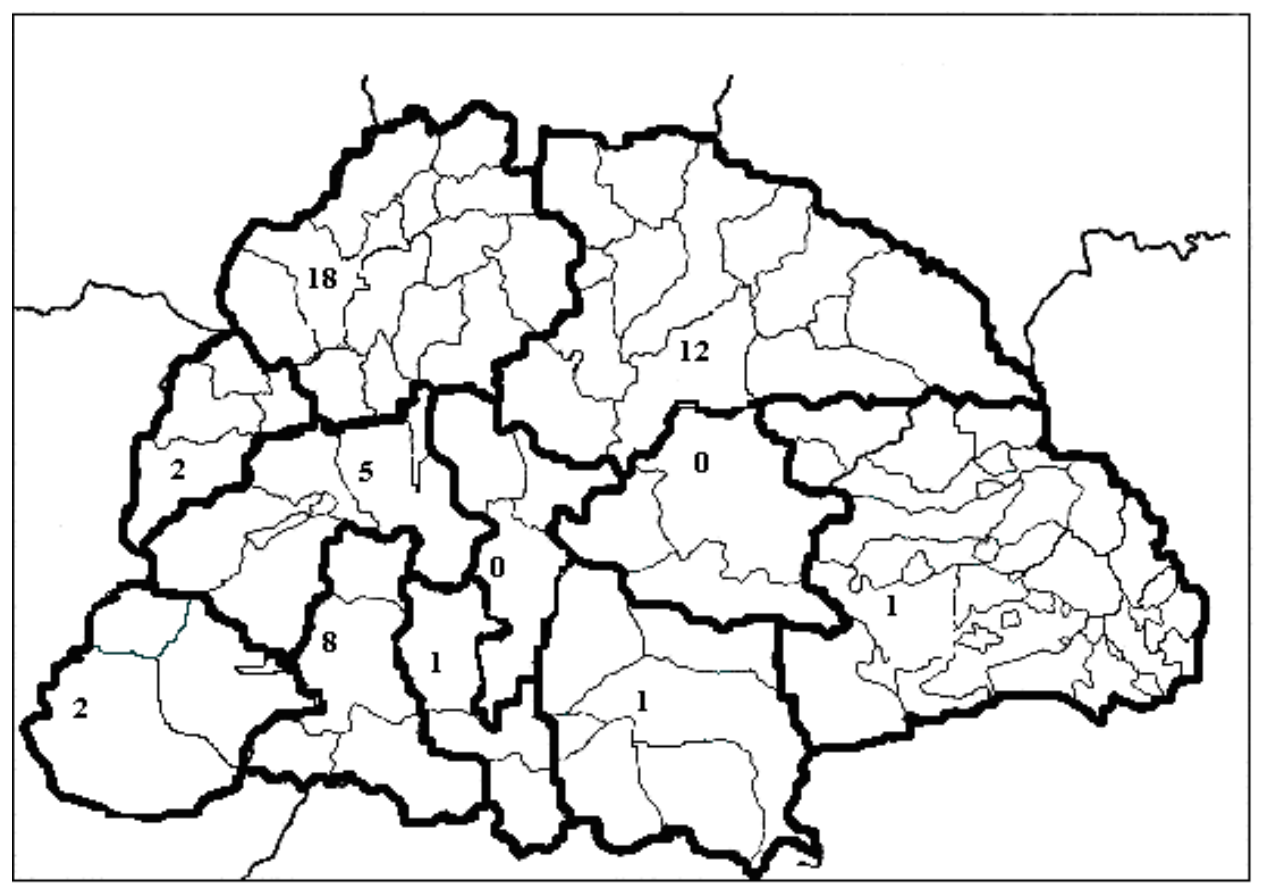

6. ábra: Az Iwan földrajzi megoszlása az 1301-1359 közötti korpusz alapján (db)

A korpuszban a Johannes, Joachim és Joseph latin alapnévnek összesen 147 i-s kezdetú változata szerepel. Ezek többsége, mint az az 5. ábrán látszik, a Dunától nyugatra, illetve az ország két északi régiójára tehető. Bár a magyar hangtörténeti változás mellett itt az Iván név miatt a szláv hatást sem zárhatjuk ki, ez láthatólag legfeljebb a két északi régióban, a keleti szlávok miatt jellemzóbben inkább az egriben okozhatott némi többletet, hiszen a déli országrészből a pécsi régiót kivéve alig van adatunk. Ezek alapján úgy tűnik, hogy a változatok névföldrajzi elemzése megerôsíti a korábbi szakirodalom megállapítását. Ennek ellenére a számos bizonytalanság és a kevés, ráadásul régiónként eltérő nagyságrendben rendelkezésre álló adat miatt komoly fenntartásokkal kell kezelnünk ezt az eredményt. Ha ugyanis az $i$ - kezdetú változatok számát a vizsgált nevek összes előfordulásához viszonyítva nézzük az adott 
régiókban, akkor a csanádi régió 2 adata 17\%-ot, míg az egri 33 adata mindössze 7\%-ot tesz ki. Mindezek figyelembevételével úgy vélem, a korpusz adatai nem nyújtanak biztos támpontot e hangváltozás területi kiterjedésének a vizsgálatára.

Az eredményt ennek ellenére érdemes összevetni a Történeti magyar családnévatlasz (TMCsA.) ${ }^{13}$ adatbázisának az 1720-as országos összeírásra épülő keresztnévanyagával, illetve annak az Iván és Jován név alapján rajzolt térképlapjaival is (7-8. ábra). Mivel ugyanis a szinkrón családnévanyag Jubász és Ihász nevének területi megoszlása alkalmasnak bizonyult a ju-/jo- $>i$ - változás elterjedtségének a felmérésére, egy, a változás korához közelebbi időszak vizsgálata feltehetőleg még pontosabb eredményeket hozhat. Ehhez azonban a három név (Johannes, Joachim és Joseph) változatai közül is csupán az Iván adatai maradhatnak a 14. századi állapotot ábrázoló térképen (1. 6. ábra). E kép nem tér el sokban a korábbitól: a legtöbb előfordulás északon tapasztalható, keletrôl viszont alig vagy egyáltalán nincs adatunk az Iván-ra.

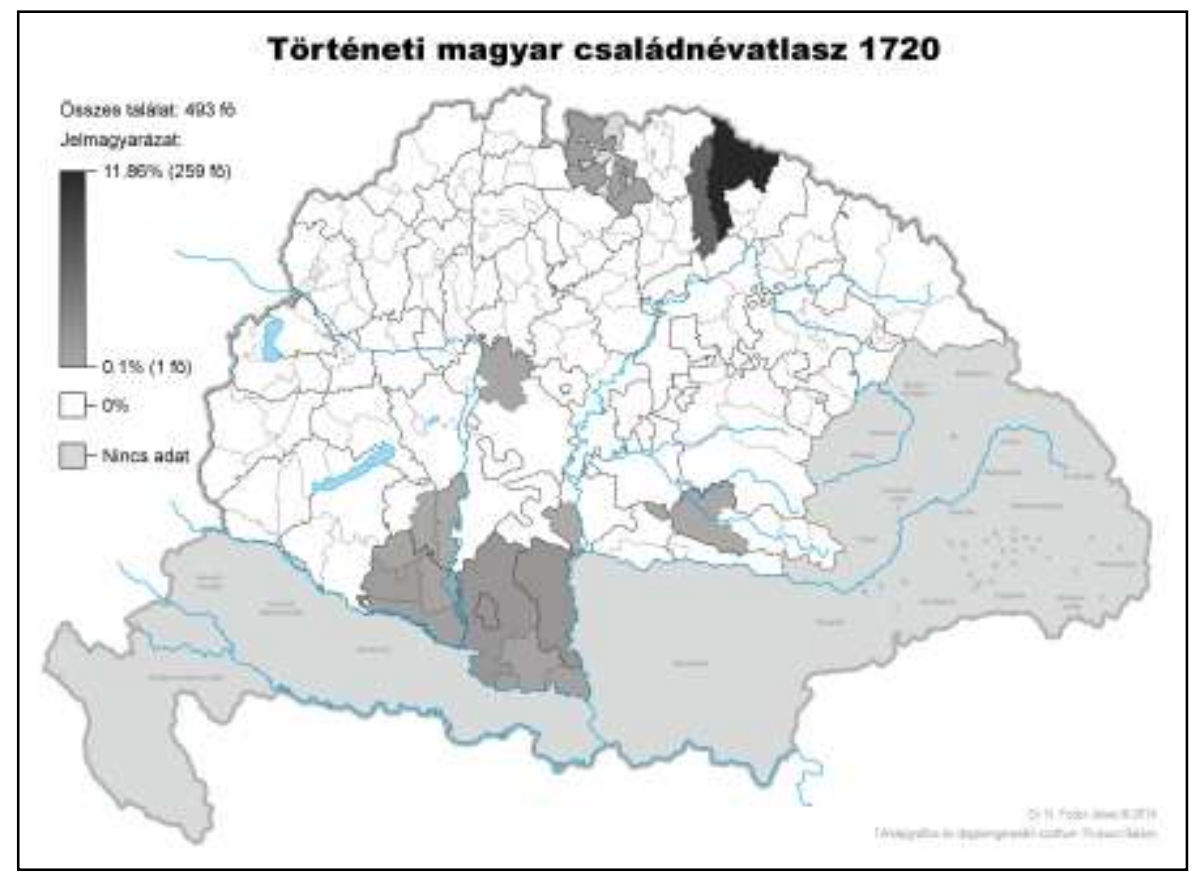

7. ábra: Az Iván-nak és változatainak a földrajzi megoszlása a TMCsA. alapján (1720)

13 Ezúton is köszönöm a kutatás vezetőjének, N. Fodor Jánosnak, hogy biztosította számomra az adatbázishoz való hozzáférést. 
Az 1720-as összeírás alapján az Iván-nak és változatainak az adatait térképre vetítve (7. ábra) azonban meglepő eredményt kapunk: a 14. századi térképen legtöbb adattal rendelkező régiókból mindössze az egri régió két megyéjéből (innen viszont az egész országban legnagyobb arányban Zemplénből), valamint Baranyából és Tolnából van adat, miközben a középső rész Dunától keletre eső fele (Bács-Bodrog, a Sajkás kerület, valamint Csongrád és Zaránd egy része), mely a 14. századi térképen igen kevés adattal jelenik meg, itt erősebben érintettnek tűnik.

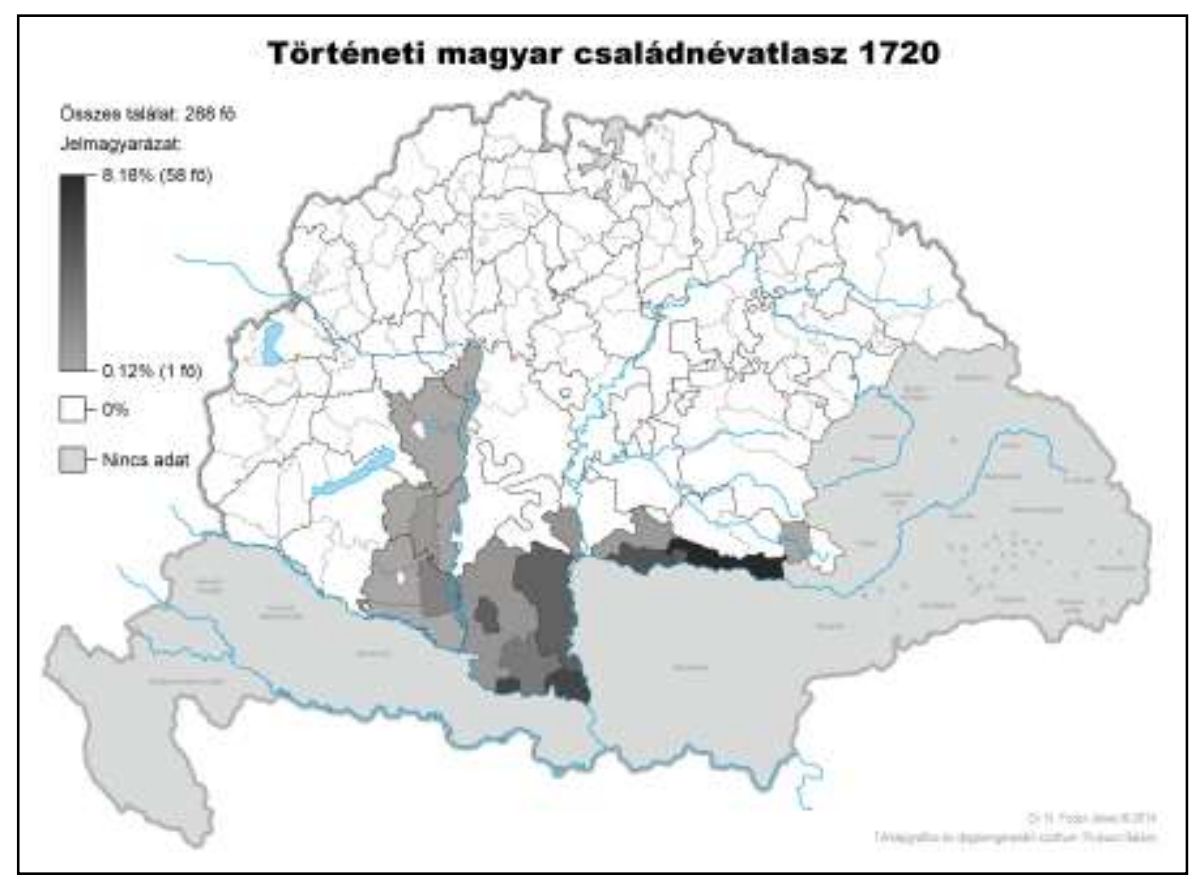

8. ábra: A Jován-nak és változatainak a földrajzi megoszlása a TMCsA. alapján (1720)

A 14. és 18. századi térkép közötti ellentmondás okát a Jován 1720-as adatainak térképre vetítésével tárhatjuk fel (első közlése: N. FODOR 2014: 37). A 8. ábra viszonylag nagy hasonlóságot mutat az Iván térképlapjával. Az északkeleti megyékben és Pest megyében ugyanakkor az Iván-nal szemben a Jován nem fordul elő. Ez nem is meglepő, hiszen az Iván a szláv nyelvcsalád több ágában is megtalálható, bár leginkább a keleti szlávra jellemző, ahogyan azt a zempléni adatok is mutatják. Déli jelenléte a szerbek mellett nagy valószínűséggel némileg már a ruszinoknak a török kiűzése után meginduló, Bácskába és a Szerémségbe való beköltözésével is összefügghet, habár e népességmozgás még 1720 után is javában zajlott. Ezzel szemben a Jován jellegzetesen déli szláv változat, így érthető módon a szerbek által nagyobb arányban lakott 
déli vidékeken jelenik meg, illetve azokon a területeken, amelyeken a török elől a Duna vonalát követve északabbra menekülő szerb lakosság megtelepedett. (Erról bővebben 1 . N. FODOR 2014: 37-38.) A két térképlap hasonlósága alapján arra lehet következtetni, hogy a János, az Iván és a Jován a 18. századra már nem ugyanazon név változataiként, hanem önálló nevekként éltek a névhasználók tudatában, és a két utóbbi, különösen pedig a Jován etnikailag jelölt lehetett. Emiatt a 18. századi térképlapokat - hasonlóan a 14. századi korpuszhoz, habár eltérő okból - nem használhatjuk fel a ju-/jo- $>i$-változás területi elterjedésének vizsgálatára.

\subsection{A genealógia tanúsága}

\subsubsection{A genealógia szerepe a személynévtörténeti kutatásokban}

A személynévtörténeti kutatás nem nélkülözheti a genealógiai és archontológiai szakirodalom segítségét, hiszen már a névadatok gyüjtése, valamint a névviselőknek az azonosítása is komoly nehézségekbe ütközne e két terület eredményeinek felhasználása nélkül. Amellett azonban, hogy a család- és birtoklástörténet, valamint a különféle méltóság- és tisztségviselők névsora lehetővé teheti a nevek személyhez és családhoz kapcsolását, a névviselők társadalmi állásának, lakhelyének vagy birtokainak a meghatározását és időben való elhelyezését, e segédtudományok további fontos területeken is felbecsülhetetlen információt szolgáltathatnak a személynévtörténeti kutatás számára. N. FODOR JÁNOS (2004) például annak megállapítására hívta segítségül a genealógiát, hogy mikortól beszélhetünk családnevekrőll, FEHÉRTÓI KATALIN (1975) pedig a névtörténetet a nyelvtörténeti vizsgálat szolgálatába állítva, egy mára már kihalt közszó, az új 'nagybáty' jelentésének a feltárásában támaszkodott a genealógia eredményeire. ${ }^{14}$

Magam eddigi névtörténeti vizsgálataim során már több alkalommal is felhasználtam a genealógia által nyújtott lehetőségeket a középkori névadási indítékok és szokások feltárásában. A következőkben ezek szerves folytatásaként arra igyekszem felhívni a figyelmet, hogy milyen névtörténeti kérdések vizsgálatában érdemes támaszkodnunk e tudomány tanúságára. Először a Jolánta név példáján azt mutatom be, hogyan lehet segítségünkre a leszármazás ismerete a név eredetének a meghatározásában, majd pedig a névöröklésre helyezem a hangsúlyt. Az előző részben, valamint 2011-es monográfiámban (SLíz 2011b) a névkorpusz elemzésével kimutattam,

14 Természetesen e kapcsolat fordítva is múködik: a személynévtörténeti kutatás, különösen a családnévkutatás a genealógia, helytörténet, archontológia stb. fontos segédtudománya lehet, mint arra FALLENBÜCHL ZOLTÁN (1991) felhívta a figyelmet. 
melyek a korszak, illetve általában az ómagyar kor leggyakoribb nevei; az efféle, makroszintû vizsgálatok azonban csak az általános kép megrajzolására alkalmasak. Ahhoz, hogy e kép kialakulásának az okait, a mélyben meghúzódó folyamatokat is lássuk, mikroszintû́ vizsgálatokra van szükség. Ezek sorát már 2011-es munkámban megkezdtem a szentkultusznak a névadásra gyakorolt hatását, az irodalmi eredetú névadást és a nevek nemzetségeken belüli öröklődését bemutatva. E vizsgálatok nyomvonalán haladva a továbbiakban egyrészt kitérek a házassági kapcsolatoknak a nevek terjedésében játszott szerepére, majd a nevek öröklődésének a jellemzőit igyekszem feltárni, végül pedig ennek kapcsán az öröklődésnek az irodalmi eredetú nevek divatjában betöltött funkciójára fordítom figyelmemet. Az említett vizsgálatokhoz ENGEL PÁL középkori genealógiáját (2003) használom alapvető forrásként.

\subsubsection{A genealógia szerepe a néveredet meghatározásában}

A következőkben a Jolánta név példáján azt igyekszem bemutatni, hogyan használhatók fel a genealógiai információk egy egyénnév nyelvi eredetének a feltárásában. Ennek részletesebb tárgyalása előtt azonban azt szükséges tisztázni, hogy mit értek a következőkben az eredet meghatározásán.

\subsection{Módszertani megjegyzések a néveredet meghatározása kapcsán}

Mint korábbi munkámban részletesen bemutattam (SLíz 2011b: 57-58), az egyénnevek nyelvi eredete kétféleképpen fogható fel. Egyrészt megadhatjuk azt a nyelvet, amelyben a név keletkezett, másrészt azt a nyelvet is alapul vehetjük, amelyből az adott nyelv, esetünkben a magyar átvette a szóban forgó nevet. Belső keletkezésú nevek esetében természetesen e kérdés fel sem merül, a jövevénynevek esetében azonban fontos tisztázni, hogy a fenti két szempont közül melyiket vesszük alapul, döntésünk ugyanis számos név kategorizációjára kihat: a János például a héberben keletkezett, de a magyar a latinból vette át.

A két szempont közötti választás nagyban függ attól, milyen célból keressük, és milyen közönség számára igyekszünk megadni a név etimológiáját. Azok előtt a névtárak előtt, amelyek nem korlátozódnak egyetlen nyelvre, valójában nincsen választási lehetőség: logikusan csupán a végső etimont közölhetik, hiszen az, hogy egy nemzetközileg használatos keresztnevet egy adott nyelv honnan vett át, nyelvenként változó. Az egy nyelv névállományát leíró szótárak esetében viszont már van lehetőség a döntésre.

A napjaink magyar keresztnévállományát leíró névtárak általában a végső etimont közlik, vagy - nem feltétlenül következetesen - ötvözik a két eltérő szempontot, hogy a lehető legtöbb információval szolgálhassanak mind a névkutatóknak, 
mind az érdeklődő nagyközönségnek. A LADÓ-BíRÓ-féle Magyar utónévkönyv (MUnk.) például a Mibály-nak csak a végső, azaz héber eredetét adja meg, számos név kapcsán azonban részletes levezetéssel szolgál: így a Miklós „,a görög Nikolaosz név szláv formájából származik". Míg itt világosan érzékelhetők az egyes állomások (görög: a végsô etimon nyelve; szláv: átadó nyelvcsalád), addig egyes leírásokban a laikusok számára kibogozhatatlanul összekeveredik a két szempont, amint azt a Lázár leírása is tükrözi: „A héber Eleazár név görög rövidüléséből, ill. ennek a latin Lazarus formájából származik". Az olvasóban felmerülhet a kérdés, hogy mit takar vajon az illetve: 'és'-t, 'vagy'-ot, netán 'pontosabban'-t. Hasonló fejtörést okozhat a Tamás leírása is: „A bibliai, héber (arameus) eredetű Teomo névből származik”. Ebben háttértudás nélkül a „héber (arameus)” többféleképpen is értelmezhető: 'héber vagy arameus', 'héber és arameus', 'héber, más néven arameus', 'héber, amely az arameusra vezethetô vissza', 'arameus, amely a héberre vezethetô vissza'.

Az efféle, különböző szempontokat vegyítő etimológiák nemcsak szakmai téren vezethetnek tévedésekhez, illetve bizonytalanságokhoz, hanem a laikusok körében is zavart okozhatnak, sôt ami ennél is komolyabb probléma, egyes laikus nyelvrokonságelméletek is igazolást láthatnak az olyan, a nyelvek közötti viszonyokat világosan nem tükröztető etimológiákban, mint a „babilóniai, akkád eredetú bibliai név” (Baltazár), „török eredetủ régi magyar személynév, nemzetségnév, majd keresztnév a XI-XV. században” (Aba), ,germán eredetú magyar név" (Aldor). ${ }^{15}$

A középkori személynévanyagot közlő névtárak és feldolgozások a szinkrón névanyagot közreadó névtárakkal szemben általában korlátozottabb felhasználásra, a szúkebb szakma számára készülnek, és elsődleges céljuk nem a nevek részletes bemutatása, hanem történeti adataik közlése, egy korszak névállományának bemutatása, akár eredet szerint is. Ennek ellenére ezekben is többféle megoldással találkozunk. Az ÁSznt. a számos nehézség miatt nem közöl etimológiákat, BERRÁR (1952) pedig általában a végső etimont vette figyelembe. Így például az Izolda (Iz̧salt címszó alatt) a francia eredetű nevek között szerepel, megjegyzésként pedig azt olvashatjuk, hogy „hozzánk is német közvetítéssel jöhetett” (BERRÁR 1952: 45). Magam már a korpuszom első felét közzétevő névtárban és annak feldolgozásában is (SLíz 2011a, 2011b) a közvetlen átadót vettem alapul, mivel véleményem szerint a középkori magyar névállomány eredet szerinti összetételét kizárólag ez a megoldás tárhatja fel hitelesen. A következőkben tehát ezt, azaz a közvetlen átadó nyelv megállapítását értem a név eredetének feltárásán.

${ }^{15}$ E laikus elméletek híveinek nevek iránti érdeklődését jól tükrözik a könyvesboltokban kapható, illetve az interneten elérhető tudománytalan keresztnévtárak, valamint a laikus helynév-etimológiák, illetve azoknak az említett elméletekben betöltött jelentős szerepe is. (Ez utóbbiak részletes értékelésére l. IMREH 2014, 2015). 


\subsection{A Jolánta név eredete: a genealógia tanúsága}

A Jolánta név különösen alkalmas tárgya lehet egy, az eredet meghatározását bemutató módszertani esettanulmánynak, hiszen származása körül több bizonytalanság is mutatkozik. Az első, hogy e nevet tévesen a Jolán-nal azonosították: így IV. Béla lányát sok helyütt Árpádhári Boldog Jolán-nak nevezik (vö. pl. MKL.), de a Wikipédián a Magyarországi Jolán aragóniai királynê16 címszóval is találkozunk II. András és Jolánta királyné Jolánta nevú lányának a megnevezéseként. Pedig a Jolán név jóval későbbi, mint a Jolánta, és azzal ellentétben belső keletkezésú: Dugonics András alkotta a 19. század elején Jolánka, Etelkának leánya címủ regénye (1803-1804) hősnőjének neveként a középkori magyar Jóleán névből (vö. MUnk. Jolán a.). A két névnek tehát - ellentétben a közhasználattal - eredet szempontjából semmi köze sincs egymáshoz. A továbbiakban emiatt a Jolán-nal nem is foglalkozom, hanem a Jolántá-ra irányítom a figyelmemet.

A Jolánta címszó alatt a MUnk. a név eredetéről a következőt írja: „A görög eredetủ Jolanda női név régi magyar formája." Mivel a névtár, mint fentebb láttuk, többnyire a végső eredetet adja meg, esetenként azt is hozzátéve, hogy milyen úton került a név a magyarba, feltételezhető, hogy jelen esetben is a végső eredetről van szó; arról pedig semmit tudunk meg, hogy a név egyenesen a görögből, vagy valamely más nyelven keresztül került-e a magyarba. BÁRCZI GÉZA (1938) és BERRÁR JOLÁN (1952: 44-45) szerint viszont a név az ófrancia Yolent-ből származik. Az nem derül ki, hogy BERRÁR ezt a név végső eredetének tartja-e, mivel azonban máskor a végső eredetet közli, feltételezhető, hogy vagy nem kapcsolta össze e nevet a görög Jolandá-val (mindenesetre egyszer sem utal görög etimonra), vagy ebben az esetben eltért az általában követett elvtől, és a közvetlen átadó nyelvet jelölte meg.

Az ellentmondás feloldása érdekében először is érdemes megvizsgálni a név magyarországi adatait az ÁSznt. alapján. Ezekből azonban - mint azt alább részletesen is bemutatom - az derül ki, hogy a név eredetének meghatározása előtt a számos, egymástól néha jelentős mértékben eltérő alakváltozat egymáshoz való viszonyát kell tisztáznunk. A következőkben ezt végzem el, részben nyelvtudományi, részben genealógiai érvekre támaszkodva.

A névtárban a név adatai több címszó alatt elszórva találhatók meg annak ellenére, hogy a névváltozatok egy része világosan összekapcsolható lenne egymással a genealógiai információk alapján. Így a Iolent stb. címszó alatt (ÁSznt. 423) található 1235-ös Joleth adat egyértelműen II. András Jolánta nevű leányát jelöli, s aligha vonható kétségbe, hogy e leány az anyjáról, I. (Courtenay) Péter konstantinápolyi latin

${ }^{16}$ https://hu.wikipedia.org/wiki/Magyarorsz\%C3\%A1gi_Jol\%C3\%A1n_arag\%C3\%B3niai_kir $\%$ C3\%A 1 lyn $\%$ C3\%A9 
császár lányáról, Jolántáról kaphatta a nevét; e név ugyanis korábban nem fordult elő az Árpád-házban. Az anya neve azonban két másik szócikkben, a Iolenta, Iolanta és a Ioles, Iolis címszó alatt tűnik fel (ÁSznt. 423), a következő két alakban: Jolente (1218), Yoles (1217, 1220, 1227/XVIII, 1235), Joles (1224), valamint ez utóbbiak accusativusi változatában. Tény, hogy az 1235-ös adatokat tartalmazó oklevél (DL61134) eltérő alakban közli anya (Yoles) és leánya (Joleth) nevét. Ez azonban aligha lehet érv a két változat különválasztására, hiszen számtalan példát ismerünk arra, hogy ugyanazon oklevélben ugyanazon név többféle változatban jelenik meg, legyen szó akár puszta írásváltozatokról, akár morfológiailag is eltéró alakváltozatokról. Egy további szócikkben (ÁSznt. 423. Iolen) IV. Béla már említett, később boldoggá avatott leányának a neve a következőképpen jelenik meg: Jolen (1263 [1269]). A családfát figyelembe véve nemigen lehet kétséges, hogy e hercegnő apja mostohaanyjáról vagy húgáról, azaz II. András említett feleségéről vagy leányáról kaphatta a nevét, így ez a változat szintén a Jolántá-hoz tartozik. Erre utal is a névtár, amikor a szócikk végén a Iolent szócikkhez igazít, csak az nem világos, hogy miért szerepel mégis külön szócikkben az adat. Ráadásul ugyanitt a Iolian szócikkhez is találunk utalást, ami további bizonytalanságokhoz vezet.

Véleményem szerint többszörös keveredés történt a szócikkek között: egyrészt a Jolánta adatai legalább négy különböző szócikkbe kerültek, másrészt a Iolian tévesen lett az egyikükhöz kapcsolva utalóval. Valójában ugyanis két, eltérő eredetú névrôl van szó: a Iolian 'Jóleány' magyar eredetű, és a szintén létező Jólegény, Jóember sorba illeszkedik (ÁSznt. 419. Ioember; 422. Iolegen stb.), míg a Jolenth, a Ioles és a Iolen egyaránt az idegen eredetủ Jolánta alakváltozatai. Ezt támasztja alá az is, hogy míg a Jolántá-k mind BERRÁRnál, mind saját adattáramban (vö. SLíz 2011a: 236. Jolenth) szinte kizárólag a nemesség köréből kerülnek ki (BERRÁRnál 19 úrnő és 1 szolgáló, 1952: 45), addig a Iolian szócikk egyetlen névadata egy szolgálóra vonatkozik. Arra persze több példát is ismerünk, hogy a korabeli névhasználók, vagy legalábbis egyes scriptorok tévesen kapcsoltak össze eltérő eredetű neveket, illetve hogy egy-két névváltozat több alapnévhez is kapcsolódhatott (1. pl. a már említett Nyeste és Anasztária vagy a Tristanus és a Christianus esetét; vö. pl. BENKŐ 1948, RÁCZ 1956b: 50, KOROMPAY 1980: 520, SLÍZ 2011b: 50-54). A Jolánta esetében azonban nem rendelkezünk olyan adatokkal, amelyek szerint ugyanazt a nőt egyszer a Jolánta valamely változatával, másszor pedig a Jóleány-nyal jelölték volna meg, ezért nincs okunk e két névnek a korabeli névhasználói tudatban való keveredését feltételezni.

Ami a Jolánta alakváltozatait illeti, az említettek mellett továbbiakkal is találkozhatunk a Iolent stb. szócikkben (ÁSznt. 423): Jolonth, Jolent, Jolenth, Johalent, Johalenth, Jolint. Saját, 14. századi korpuszomban kizárólag a Jolenth változat fordul elő. Az eddig ismertetett változatok közül leginkább kilógó Johalent(h) alak BERRÁR szerint (1952: 45) idegen mintára keletkezhetett. Véleményem szerint azonban magyar fejlemény is lehet: valószínűleg a hasonló alakú Johannes, Johanna hatásával magyarázható. Az ÁSznt.-ből legalábbis az rajzolódik ki, hogy több, eltérő etimológiájú, Jo- kezdetű 
férfi- és nôi név alakja is hathatott egymásra: az ismeretlen eredetű Jólát férfinévnek ugyanis szintén van Jolánt változata (vö. ÁSznt. 422. Iolant, Ialat), a Johannes-nek pedig Johanta változata (ÁSznt. 422. Iohanta). Ez utóbbiba bizonyára a Jolánta hatására kerülhetett a -t, ahogy a Johalent(b) alakkal világosan összekapcsolható volta ellenére külön szócikkben szereplő Johaleta nôi név is (ÁSznt. 419. Iobaleta) feltehetőleg a Johanna és a Jolánta név Joleth változatának a vegyülésével keletkezhetett. A többitôl szintén erősebben különböző Joles, Jolis változat kapcsán egyetérthetünk BERRÁR JOLÁNnal abban, hogy nagy valószínűséggel rövidüléssel és -s képzővel való továbbképzéssel jöhetett létre (vö. 1952: 45).

A fennmaradó, egymáshoz közelebb álló alakváltozatok alapján úgy tűnik, az átvett alak a Jolenth lehetett. Ezt számos érv támasztja alá, melyek külön-külön nem, együttesen azonban elegendő bizonyítékkal szolgálnak. Érdemes például kiemelni, hogy ez a leggyakoribb változat, ráadásul a második magánhangzóként -e- hangot tartalmazó adatok száma messze meghaladja az -a-t tartalmazókét. A Jolonth változat is ezt a feltevést támogatja, hiszen nyilván hangrendi kiegyenlítődés erdményeképpen jött létre a vegyes hangrendű alakból (vö. BÁRCZI G. 1938: 13. is). A név végződését tekintve az nyilvánvaló, hogy a Jolen alak másodlagos, hiszen az adatok többségében, valamint a francia változatokban is szerepel az - $n$ után mássalhangzó, és a 13. század első felében, a név átvételének feltételezett idejében az ófranciában még ejtették a szó végi -t-t (vö. BÁRCZI G. 1938: 11). Feltűnő továbbá, hogy bár más nyelvekben találunk - $d$-s változatot (pl. 1378: Yolendis, franciaországi latin forrásból; UCKELMAN-UCKELMAN 2016), és a mai angol és francia változat is Yolanda, illetve Yolande, a magyarban egyetlen $-d$-s adat sem került eddig elő. Az -a végződés hiánya az adatok többségén emellett arról árulkodik, hogy az átvett név feltehetőleg mássalhangzóra végződhetett. Mivel ugyanis a középkori magyarországi női nevek állománya jelentôs részben a latinból átvett nevekből állt, ezeknek pedig tipikus végződésük az -a, egy Jolentha alak gond nélkül beilleszkedhetett volna a névrendszerbe. (Habár arra is tudunk példát, amikor egy - $a$ végú név végül mássalhangzós végződésú változatban vált alapnévvé: Margaretha $>$ Margit, Katherina $>$ Katalin. Ezek középkori adatai között azonban még elsöprő többségben vannak a magánhangzós végúek, vö. pl. ÁSznt. 450-451. Katarina stb., 516-517. Margareta stb., SLÍZ 2011a. Katherina). Mindezek alapján BÁRCZI GÉZÁval (1938: 13) egyetértve úgy vélem, hogy a magánhangzós végú Jolánta alak latinizálás eredménye lehet.

Az eddigi változatok mellett meg kell még említeni egy 1304-es violenta (AO. 1: 82) adatot is. Ezt BERRÁR nem kapcsolja össze a Jolántá-val, hanem az egyéb nyugati eredetű nevek közé sorolja, és WERTNER (1916-1917: 315) alapján az olaszból eredezteti (BERRÁR 1952: 46, 59). A több európai országból és nyelvterületről származó, nemzetközi szerkesztőbizottsággal rendelkező Dictionary of Medieval Names from European Sources viszont a Yolanda alatt sorolja fel a vi-kezdetú neveket is, jellemzően újlatin nyelvterületről, latin nyelvű középkori forrásokból: 1487: Violans (Spanyolország), 1522-1532: Violante (Itália), sôt katalán forrásokban is megjelenik 
e változat: 1488: Violant (vö. UCKELMAN-UCKELMAN 2016). Mint látható, van itáliai adat is közöttük, ez tehát nem zárja ki a Violenta olaszból való származtatását. Ez azonban még nem oldotta meg a problémát, ugyanis a sokféle alak és adat alapján legalább három (illetve az aleseteket külön számolva: négy) lehetőség adódik: (1) A két név (Jolánta és Violenta) ugyanazon 'viola' jelentésű szóból, de egymástól függetlenül jött létre a görögben és a latinban. (2) Amennyiben az ófrancia Jolenth nevet nem fogadjuk el a Jolanta változatának, három külön névről van szó, melyek a görögben, a latinban és a franciában, egymástól függetlenül keletkeztek. A j- és vikezdetű alakok összekapcsolása mindkét esetben a hasonló alak és az azonos etimológiai jelentés okozta keveredés eredménye. (3a) A Violenta a görög név latinra fordításának az eredménye, hiszen a virágnév latin változata (viola) jelenik meg benne. Ez aztán a latinból akár közvetlenül, akár az olaszon keresztül bekerült a magyar névkészletbe, így a kétféle (j- és vi- kezdetü) változat egymás mellett élt. Ez nem lenne meglepő, hiszen ismerünk olyan esetet, amikor egy latin alapnévnek a magyarban kialakult változata mellett egy másik nyelvből átvett változata is jelen van a magyarban (pl. a magyarban alakult Erzsébet és valamely nyugati újlatin nyelvből átvett Irabella). (3b) A Violenta Magyarországon nem élő névhasználatot tükröz, csupán az élőszóban használt, $j$ - kezdetú névváltozatok valamelyikének az oklevélben latinosított, „hivatalosított” változata.

Az eddigi bizonyítékok alapján úgy vélem, hogy e lehetőségek közül a harmadik a legmeggyőzőbb; legalábbis jóval könnyebb elképzelni, hogy egy név egész Európában, számos nyelvben elterjedt (különösen a számtalan példa alapján), mint azt feltételezni, hogy ugyanazon jelentésủ szóból egymástól függetlenül több nyelvben keletkeztek nevek, majd ezek késôbb összekeveredtek (1. Ockham borotvája). Véleményem szerint a név - annyi más görög névhez hasonlóan - a görögből a latinba bekerülve terjedt el Nyugat-Európában, legalábbis német és francia nyelvterületen. A magyarba így három úton is bekerülhetett: a görögből, a latinból és valamely nyugati vulgáris nyelvből. Mivel a görög eredetű neveket jellemzően nem közvetlenül a bizánci görögből vettük át, hanem a latin vagy valamely vulgáris nyelv, gyakran egy szláv nyelv közvetítésével, a közvetlen görög átvételt kevésbé tartom valószínűnek. A név végi magánhangzó hiánya, valamint a 13-14. századi francia adatoknak a magyar forrásokban leggyakoribb, általam a feltételezhető átvett formaként levezetett Jolent( $h$ ) alakkal való feltűnő hasonlósága (1292: Yolent, Hyolent; 1302: Yolent; UCKELMANUCKELMAN 2016) alapján az látszik a leghihetőbbnek, hogy az átadó nyelv a francia lehetett. Annak megitélésére azonban, hogy a vi- kezdetű változat élő névhasználatot tükröz-e, egyetlen adat alapján természetesen nincs lehetőségünk.

A nyelvtörténeti bizonyitékok alapján kirajzolódó következtetést érdemes megtámogatnunk a genealógia oldaláról is. A név történeti adataiból ugyanis kiderül, hogy legkorábbi ismert előfordulása 1217-es (ÁSznt. 423. Ioles, Iolis; BERRÁR 1952: 44-45), és II. András említett feleségére vonatkozik. Az első, nem őt vagy azonos nevű leányát jelölő adat évtizedekkel későbbről, 1263-ból való (ÁSznt. 423. Iolenta, 
Iolanta). ENGEL középkori genealógiájában (2003) öt Jolántát találunk, de a legkorábbit is csak 1272-ben említik, így az ő születése sem igen előzhette meg a királyné Magyarországra érkezését. Ezek alapján talán feltételezhető, hogy a név II. András felesége révén vált a magyarországi személynévállomány részévé. (Így vélekedett BERRÁR is; 1952: 59.) Ebből következőleg tehát már csak azt kell kiderítenünk, milyen nyelvterületről származhatott a királyné neve; ebben lehet segítségünkre a genealógia.

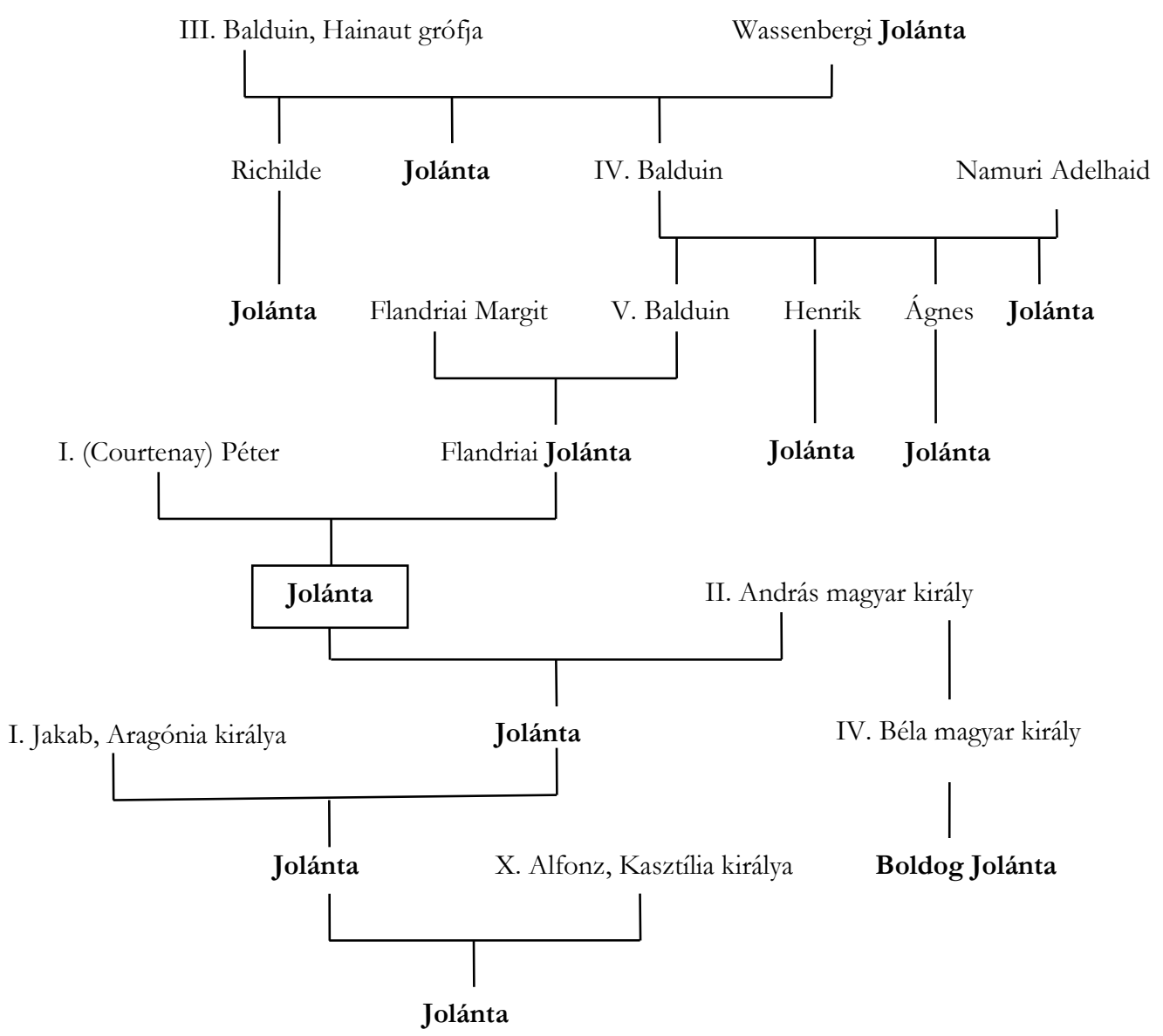

9. ábra: A Jolánta név elterjedése Hainaut grófi családjától a Kasztíliában uralkodó Burgundiai-házig ${ }^{17}$

${ }^{17}$ A családfa alapjául szolgáló munka: CAWLEY-FMG 2006-2015. 


\subsubsection{A házassági kapcsolatok hatása a nevek terjedésére a középkori magyar nemesség körében}

Korábban már több munkámban is foglalkoztam az uralkodócsaládok névadásával (SLíz 2000, 2011b: 141-149, 2013c, 2015b). Ennek során bemutattam, hogy milyen kapcsolat lehetett a név mint szimbólum és az uralkodócsalád, szorosabban véve az apa kül- és belpolitikai céljai között, valamint hogy miképpen befolyásolta a vallás ('́gy a kereszténység felvétele és a szentkultusz) a dinasztián belüli névválasztást. E két fő indíték révén ugyanis az uralkodóházak anyanyelvből származó névállománya jelentősen bővült más nyelvekből származó nevekkel a különböző dinasztiákkal való kapcsolat, valamint az e kapcsolat következtében őket érő kulturális hatások révén. A vizsgálatok során azt is megállapítottam, hogy a nemek között különbség érzékelhető a névadási indítékokat tekintve; e különbség a középkori női és férfiszerepek közötti eltérésből adódik (a férfi potenciális uralkodó, a nő ellenben a szövetségépítés egyik fontos eszköze lehet). Mivel az uralkodóházak névadása láthatólag a köznépétől részben eltérő indítékokon alapszik, ennek a motívumrendszernek a megnevezésére bevezettem a dinasztikus névadás terminust.

Mint korábban kimutattam, a középkori nemességnek, de legalábbis a legfelsőbb rétegnek a névadási gyakorlata feltűnổ hasonlóságokat mutat az uralkodóházak névadásával (SLÍZ 2011b: 167): az egyénnév az ô esetükben is lehet a családhoz tartozás szimbóluma (1. pl. a nemzetségekre jellemző világi neveket), ahogyan a politikai kapcsolatok kifejezője is. Ez alátámasztja FÜGEDI ERIK megállapítását, mely szerint az arisztokrácia házasságpolitikája a királyok dinasztikus politikáját utánozta, s a házasság célja nemcsak a család fenntartása, hanem politikájának továbbvitele is volt (FÜGEDI 1974: 198).

Nemrégiben egy módszertani indíttatású tanulmányomban bemutattam, hogyan hasznosíthatók a genelógia és a mikrotörténelem elvei és módszerei a személynévállomány vizsgálatában (SLÍZ 2013a). A következőkben ismét az e tanulmányban feldolgozott példát, a Dorottya névnek a Garai-rokonságban való elterjedését veszem alapul, ezúttal azonban nem a módszertani kérdésekre, hanem a névöröklés vizsgálatára koncentrálva.

A szóban forgó rokonság választását történettudományi szempontból két fontos tényező indokolja. Egyrészt a 14. század második felétől már jóval nagyobb mennyiségú adattal rendelkezünk, ennek következtében a genealógiai táblák részletesebbek lehetnek, és nagyobb eséllyel szerepelnek rajtuk női családtagok. Másrészt a Garaiaknak, különösen I. és II. Miklós nádornak a tervszerú házassági politikájára, mely világosan kirajzolódik előttünk a genealógiai és archontológiai adatoknak köszönhetően, a történettudomány már jóval korábban felfigyelt. FÜGEDI ERIK megállapítása szerint e rokonság olyan fokú politikai-családi összefonódást tükröz, 
amilyen sem korábban, sem később nemigen tapasztalható. 1435-ben ugyanis, két évvel Garai II. Miklós nádor halála után az üresedésben lévő szörényi kivételével minden bánság élén Garai-rokon állt (dalmát-horvát: Frangepán János és István, II. Miklós unokaöccsei; macsói: Garai László, II. Miklós fia és Garai Dezső, II. Miklós másod-unokatestvérének a fia; szlavón: Tallóci Máté, aki II. Miklós fiának, Miklósnak az özvegyét vette feleségül). A többi kormányzati tisztséget is a Garaiak távolabbi, házasság révén szerzett rokonai viselték. (Bôvebben l. FüGEDI 1974: 172-173.) Az esetet akár kivételesnek is tekinthetnénk, ezért gondolhatnánk, hogy nem a legalkalmasabb példa a korabeli arisztokrácia névadási indítékainak, az arra általánosan jellemző vonásoknak a bemutatására. Csakhogy egy olyan, adathiányos korszak kapcsán, mint amilyen a középkor, e rokonság éppen kiterjedtségénél és jól adatolt voltánál fogva alkalmas a középkori arisztokrácia politikai, házassági és névadási stratégiája közötti összefüggések feltárására, hiszen koncentrált formában tárja elénk a máshol legfeljebb csak töredékesen megfigyelhetô képet.

A Dorottya név és a Garai-rokonság választásának emellett névtudományi módszertani oka is van. Mint a dinasztikus névadás elemzése során kiderült, a férfinevek jellemzően férfiágon öröklődtek, és csak kivételes esetben kerültek át házasság révén egy másik családba. Ilyen például a Kórógyiaknál a Keled név, amely Keled lányának és Báncsa nb. Bencencnek a házassága révén került a családba, vagy az Atyusz, amely Atyusz nembeli Évának köszönhetően jelenhetett meg a Buzád-Hahót nemzetségben Buzáddal való házassága révén (mindkettő 13. századi adat, vö. ENGEL 2003). Ezzel szemben a női nevek kevésbé voltak alávetve a családi politikának, hiszen a nők említett szerepénél fogva kevésbé számítottak szimbólumnak; ezért egyegy családon belüli állományuk általában heterogénebb is volt, mint a férfineveké. Ebből következőleg a házassági stratégiák névtani összefüggéseit leginkább a női nevek anyai ágon való öröklődésének, azaz egyik családról a másikra való átterjedésének a megfigyelése révén lehet feltárni, ahogy ezt fentebb a Jolánta példája is igazolta.

Az efféle vizsgálatokat azonban számos tényező nehezíti. A legfőbb ezek közül, hogy a középkori oklevelek köztudomásúlag igen kevés nő nevét örökítették meg, így a legtöbb esetben nem áll rendelkezésünkre az anya neve, vagy ha a név ki is derül, nem tudni, mely családból, nemzetségből származott a viselője. Ennek következtében egyrészt számos rokonsági kapcsolat marad homályban, másrészt erősen leszűkül a felhasználható nevek állománya. Ebből az is következik, hogy hiába ismerjük egy arisztokrata család nőtagjainak a nevét, nem tudhatjuk, hogy az adott név nem fordult-e már elő korábban is a családfán. Ez viszont létfontosságú lenne, hiszen ha már korábban is használatos volt a név egy adott családban, akkor megjelenése nem tulajdonítható a szóban forgó lány anyja által egy másik családból hozott névnek, azaz a két család közötti rokonság következményének. Pontosabban: ilyen esetben eldönthetetlen, hogy az adott név apai vagy anyai ágon öröklődött-e már ha egyáltalán öröklődött, és nem a korábbi előfordulás(ok)tól független okból kapta a viselóje (ez utóbbi eshetôséget természetesen sosem lehet kizárni). 
További nehézséget okoznak a megterhelt nevek: mint a női névállomány elemzésekor láthattuk, még a kis adatmennyiség ellenére is vannak ilyenek (pl. Erzsébet, Margit, Katalin). Ezeknek a családfán való megjelenése még akkor sem tulajdonítható viszonylagos biztonsággal a házassági kapcsolatoknak, ha nincs rájuk korábbról példa a családban: egyrészt számos, oklevelekben meg nem örökített emlékủ női családtag viselhette már őket, másrészt ha újdonságként jelentek meg a családfán, akkor is választhatták őket egyszerűen azért, mert a korszakban népszerű női nevek voltak.

Mindezek következtében olyan rokonságot kellett találnom a vizsgálathoz, amelynek élete, tagjainak neve és a köztük lévő vérségi, illetve házassági szálak természete kellő mértékben dokumentált. Ebben a családban pedig olyan nôi névre volt szükségem, amely: (1) nem tartozik a leggyakoribbak közé, ezért terjedése nyomon követhető; (2) ugyanakkor a lehető legnagyobb valószínűséggel meg lehet találni e terjedés kiindulópontját, azaz az első névviselőt a rokonságban. A Garaiak kiterjedt famíliája a fent bemutatott okokból megfelelt e kritériumoknak, a Dorottya név pedig azért bizonyult alkalmasnak, mert sem a vizsgálathoz általam felhasznált ENGEL-féle genealógiában (ENGEL 2003), sem BERRÁRnál (1952), sem pedig saját korpuszomnak a 13. századra datálható részében (SLÍZ 2013a) nem bukkan fel 1340 előtt. Ezzel egybeesik az a tény, hogy a Szent Dorottya-kultusz elterjedése is a 14. század második felére tehető (vö. BÁLINT 1977. 1: 210-214, MKL.), így a név népszerűsége feltehetőleg csak ekkortól kezdett növekedni.

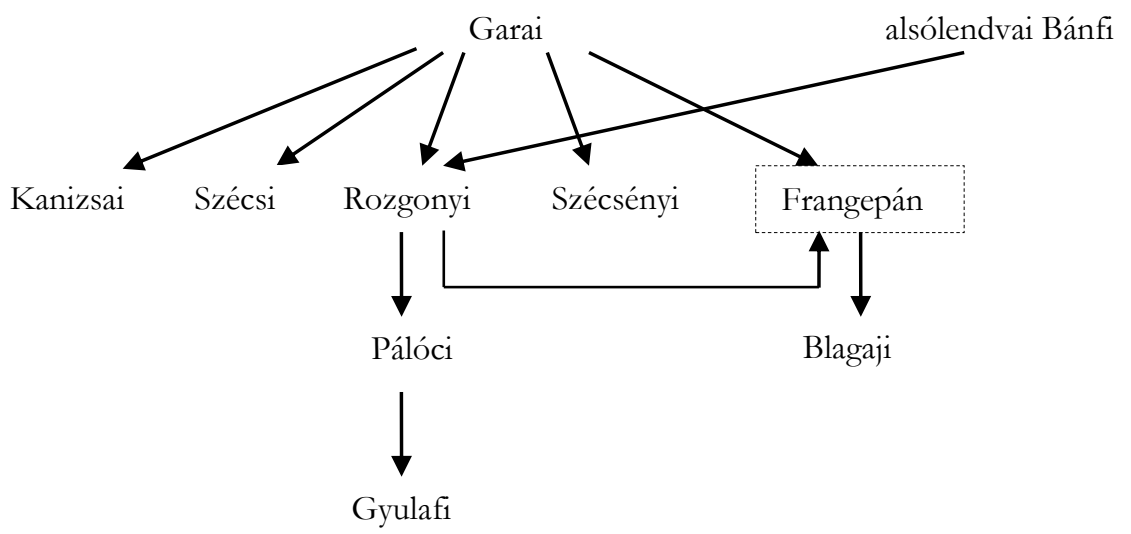

10. ábra: A Dorottya név elterjedése a Garai és az alsólendvai Bánfi családból

A vizsgálatba a Garaiak mellé később az alsólendvai Bánfi családot is bevontam, mivel közvetve ők is rokonságban álltak a Garaiakkal, és a Dorottya náluk is megterhelt név volt, így e név másik feltehető forrása e családban lehetett. Az egybehangzó névtani és kultusztörténeti adatok birtokában alapos okunk van azt feltételezni, hogy a Garai és az alsólendvai Bánfi család első, azonos időben élő Dorottyái, akikre a 
név számos, 14-16. századi, egymással rokonságban lévő arisztokrata családból visszavezethetô, elsőként viselhették e nevet a maguk családjában. Mint látjuk, a két, elsőnek tartott Dorottya között nem volt rokoni kapcsolat (hacsak az ismeretlen anyai ágon nem), tehát két külön szálat kell feltételeznünk, amelyek egy ponton, Frangepán Mihály és Rozgonyi Borbála házasságával egybekapcsolódnak. Ez nemcsak kiválóan mutatja a középkor végi arisztokrata családok közötti bonyolult, többszörös házassági kapcsolatokon alapuló összefonódásokat (ennek politikaibirtoktörténeti szempontú elemzését l. az említett tanulmányban: SLíz 2013a), hanem azt is, hogy egy korábban ritkának tekinthető név elterjedését hogyan segíthették elő az itt bemutatott rokoni szálak. Ezt támasztja alá már maga az a tény is, hogy az ENGEL-féle genealógiában (2003) fellelhető több mint 60 Dorottyá-ból 21, vagyis a nevek harmada a fenti rokonságban fordul elő. Bár az itt bemutatott példa sok tekintetben egyedi, hiszen az alsóbb rétegekben nemigen lehet a házassági kapcsolatok ennyire összetett gazdasági-politikai okaival számolni, a személynévtörténeti kutatások módszertana szempontjából általános érvényű megállapítás is leszűrhető belőle: a ritkább egyházi személynevek népszerûvé válását nem magyarázhatjuk pusztán a szentkultusz fellendülésével vagy a névdivat változásával, mivel láthatólag egyéb tényezők, így a rokonsági szálak is komoly szerepet játszhattak az elterjedésükben.

\subsubsection{A nevek öröklődésének jellemzői a középkori magyarországi nemesség körében}

Míg a nevek családról családra való terjedésének vizsgálatára a női nevek szolgálnak alkalmas eszközül, addig a családon belüli öröklődést elsősorban a férfineveken keresztül érdemes megközelíteni. Nemcsak azért, mert ehhez az esettanulmány helyett átfogóbb, nagyobb adatmennyiséget mozgató vizsgálatra van szükség, amelyet a női nevek kevésbé dokumentált volta eleve megnehezítene, sôt nagy valószínűséggel lehetetlenné is tenne, hanem azért is, mert a férfinevek erősebb szimbólumjelleget képviselnek, azaz egyik lehetséges funkciójuk éppen a családhoz való tartozás kifejezése.

Korábbi munkámban (SLíZ 2011b: 167-173) már bemutattam a középkori magyar nemzetségek névadásának néhány jellegzetességét, így a nemzetségre jellemző egyénnevek ismétlődését is, valamint a névvonatkoztatásra is mutattam példákat. A következőkben e gondolatmenetet folytatva igyekszem mélyebb összefüggéseikben is megismerni e jelenségeket, a következő kérdésekre keresve a választ: 1 . Felfedezhetô-e valamiféle minta a névöröklésben, akár az egész társadalmi réteget, akár egyes nemzetségeket vagy családokat tekintve? 2. A névismétlődés mely módja tekinthető jellemzőbbnek: a névnek apáról fiúra, nagyapáról unokára vagy oldalági rokonra való öröklődése? 3. Átlagosan hány nemzedéken keresztül öröklődnek a nevek apáról fiúra megszakítatlanul? 4. Valóban olyan jellemző egy-egy nemzetségben a névadó ős 
nevének az ismétlődése? 5 . Vannak-e egyéb, a nemzetségekre jellemző nevek, és ha igen, milyen gyakorisággal fordulnak elő? 6. A nemzetség etnikai-nyelvi eredete kifejeződik-e az általuk választott nevekben, illetve a származásuknak megfelelő idegen eredetű nevek ismétlődésében? 7. Igaz-e az, hogy az öröklődés nagyban hozzájárult a nem egyházi eredetú nevek fennmaradásához a 15. századig?

E kérdések megválaszolása érdekében többféle vizsgálatot is elvégeztem, ENGEL PÁL középkori genealógiáját (2003) használva forrásként. Ezek kapcsán fontos megjegyezni, hogy a forrás kizárólag az apai ági leszármazás figyelembevételét teszi lehetôvé, hiszen az anya személye az esetek többségében ismeretlen. Ennek azonban nincsen különösebb jelentősége: mint fentebb jeleztem, a férfineveknek egyik családból a másikba, az anyán keresztül való átkerülésére minimális mennyiségú példát lehet találni, és az uralkodóházak névadásának a vizsgálata is azt támasztja alá, hogy a férfinevek jellemzően férfiágon öröklődtek. A módszertant tekintve arról sem szabad elfeledkeznünk, hogy a forrásul szolgáló családfák bizonyára nem teljesek, hiszen összeállításuk alapjául szintén a korabeli oklevelek szolgáltak. A nemzetségek jó részének az eredete homályba vész, és bizonyára számos családtagról nem maradt feljegyzés. Ezért az alábbi számokat mindig úgy kell érteni, hogy legalább ennyi adatról van tudomásunk, de nem zárható ki, hogy a valóságban több is lehetett. További módszertani problémát jelentenek azok a személyek, akiknek a pontos leszármazása bizonytalan, csupán az adott nemzetséghez vagy ághoz való tartozásukra van adat. Ezek a családfán való elhelyezésükre vonatkozó bárminemú információ hiányában külön felsorolásban szerepelnek a genealógiában. Így azonban a név közvetlen rokonokról való öröklődésének a feltárásában nem hasznosíthatók, ezért ezeket az adatokat kizártam a kutatásból.

Az első vizsgálatban három, nagyjából azonos méretűnek ismert, ENGELnél (2003) négy-öt táblára kiterjedő nemzetséget vetettem össze. Ez nagyjából közepes méretûnek tekinthetô a mindössze egyetlen táblából álló és a tíz-tizenöt táblányit is kitevő nemzetségek között. A döntést az indokolja, hogy egyetlen tábla nem szolgálna elegendő adattal, az ötnél több tábla viszont már igencsak megnehezíti a követhetőséget és a feldolgozást. Fontos szempont volt továbbá az elemzésbe bevont nemzetségek egymástól eltérő eredete; ennek a 6 . kérdés megválaszolásában lehet jelentősége. A választásom így végül a német eredetû Hahót, a szláv eredetú Bogátradvány és a magyar eredetűnek tartott Tekele nemzetségre esett. A következőkben ezeket sorra véve, majd a nemzetségeket egymással összevetve mutatom be a névöröklés középkori nemességre jellemző főbb vonásait.

A Hahót nemzetségben összesen 112 férfinév szerepel a családfán. A névismétlődés vizsgálatának elsô lépéseként azokat a neveket gyújtöttem össze, amelyek legalább háromszor fordultak elő a 16. század elejéig. Tizenként ilyen nevet találtam; közülük négy világi (Arnold, Buðád, Csák, Habót), nyolc pedig egyházi (Dénes, István, 
Jakab, János, László, Mibály, Miklós, Péter). A világiak mind négyszer fordultak elő, ${ }^{18}$ az egyháziak között viszont voltak ennél gyakoribbak is: a László ötször, a Mihály hatszor, az István nyolcszor, a János tizennégyszer, a Miklós pedig tizenhétszer adatolható. Az utóbbi kettő kiugró gyakorisága nem meglepő, hiszen korában láthattuk, hogy országosan és a nemesség körében is a két legnépszerűbb névről van szó. A másik három szintén megtalálható az elsô tízben a nemesség körében (1. táblázat). Emiatt ez az öt név nem annyira a családon belüli öröklődésre, mint inkább a nevek országos népszerúségére látszik utalni.

A kép további árnyalására azt is felmértem, hány apa-fiú, nagyapa-unoka és nagybáty-unokaöcs közti öröklés fordul elő a családfákon. Eszerint a Hahót nemzetségben az apa nevének öröklése volt a legjellemzőbb (20 eset), ezt követi a nagyapa nevének öröklése (6 eset), végül a nagybátyé (5 eset).

Ezek után érdemes azt is megfigyelnünk, hogy melyek azok a nevek, amelyek kettőnél több generáción át, megszakítás nélkül öröklődtek egyenes ágon. (A csupán két generációnyi öröklődést azért nem vettem figyelembe, mert ezek egyedi eseteknek tekinthetők, így nem visznek előbbre annak megállapításában, hogy melyek lehettek a nemzetségre jellemző egyénnevek.) A fenti tizenkét névből így már csak öt marad, melyek mindegyike három generáción át öröklődött: Arnold, Bu₹ád, Csák, Hahót ${ }^{19}$ és Miklós. Ebbőll három következtetés adódik: az első, hogy valójában csak ez az öt név az, amelynek a gyakorisága minden kétséget kizáróan az örökítési szándéknak tudható be. A másik két következtetés a nevek eredetére vonatkozik. Jól látható ugyanis, hogy a valóban öröklődő nevek jórészt világiak, de a nemzetség német eredetére utalónak csak az Amold és a Hahót tekinthető. Ezzel szemben a Buzád magyar eredetű (vö. MUnk.), a Csák pedig talán valamely szláv nyelvre vezethető vissza (vö. FNESz. ${ }^{4}$ Csákeberény a.). Nem állíthatjuk tehát, hogy a nemzetségre jellemző nevek egyértelmű összefüggésben állnak a nemzetség nyelvi-etnikai eredetével. Ráadásul az öt név között az országosan leggyakoribbak egyike, a Mikelós is szerepel. A fenti feltevés tehát, mely szerint az országosan népszerú nevek nem vehetők figyelembe az öröklődés vizsgálatában, máris megdőlt. Ebből ismét két következtetés adódik: egyrészt ezek országos gyakoriságának az okai között is számolnunk kell az öröklődéssel, másrészt pedig kiderült, hogy a megfelelő módszer alkalmazásával ezek is alkalmasak lehetnek az öröklődés vizsgálatára.

A Bogátradvány nemzetség kapcsán elvégezve ugyanezeket a vizsgálatokat a következő eredmények rajzolódnak ki. Az előzőnél valamivel több, 149 férfinevet tartalmazó családfákon tizenhét olyan név szerepel, amely legalább háromszor fordul elő. Ezek között mindössze egy világi van: a háromszor feltűnő, feltehetőleg török

18 A Hahót első adata bizonytalan, tehát e név esetében három vagy négy előfordulással kell számolnunk.

${ }^{19}$ Illetve ha az első adat is hiteles, akkor e név négy generáción át öröklődött. 
eredetű Gyapol (FNESz. ${ }^{4}$ Gyapa a.), vagyis a nemzetség szláv származására utaló, szláv eredetű világi név nem található közöttük. A többi név: István, Miklós (13); László (12); János (11); Mibály, Péter (8); Jakab, Simon (7); György (6); Pongrác, Sándor (5); András, Domokos (4); Balázs, Benedek, Pál (3). ${ }^{20}$ Ezek többsége az országosan legnépszerúbb nevek közé tartozik, egyedül a Pongrác és a Sándor ismétlődése tekinthető a nemzetségre jellemzőnek. A rokonok közötti névöröklés is eltér a Hahót nemzetségben tapasztalttól. Míg ott az apa nevének ismétlődése volt a legjellemzóbb, itt a nagyapáe (14) és a nagybátyé (10) is gyakrabban öröklődött, mint az apáé (7). ${ }^{21}$ Ráadásul míg a Hahót nemzetségben öt név is öröklődött legalább három generáción át egyenes ágon, addig itt mindössze kettő: az István és a László, mindkettő három generáción át. E két név többi előfordulása, valamint a többi név ismétlődése tehát vagy távolabbi rokoni kapcsolatra vezethetô vissza, vagy pedig az országos népszerûségnek, egyéni tetszésnek stb., nem pedig az örökítés szándékának tudható be.

A Tekele nemben szintén tizenhét férfinév fordult elő legalább háromszor, holott a névviselők száma valamivel kevesebb, mint a Bogátradvány nemzetségben (133). Míg az előző két nemzetségben az ismétlődők között voltak világi nevek is, itt már kizárólag egyháziakkal, azok közül is az országosan gyakoriakkal találkozunk: Miklós (12); János (11); Péter (9); András (8); István (7); Pál, Lásžló (6); Jakab, Gergely, György, Tamás (5); Lórinc, Mihály (4); Demeter, Egyed, Máté, Simon (3). Itt tehát szintén nem fedezhetô fel a nemzetség eredetére utaló névadás, legalábbis látszólag. Ha ugyanis nem a példány-, hanem a típusgyakoriságot tekintjük, akkor észrevehető, hogy az első nemzedékekben viszonylag nagy számban fordulnak elő magyar, török és német eredetủ világi nevek: Bodon, Itemer, Tekele (2); Csana, Csank, Etele, Him, Lede, Usz (1). A rokonok közötti névöröklések száma itt a legalacsonyabb, és szintén a nagyapáról való öröklés túnik jellemzőbbnek: apjáról és nagybátyjáról öt, nagyapjáról hét férfi kaphatta a nevét. Kettőnél több generáción át is mindössze egyetlen név öröklődött: az országosan leggyakoribb János, három nemzedéken át.

A három nemzetségen végzett vizsgálatok eredményeinek az összevetése érdekében a rokonokról való öröklődést érdemes egyfajta „öröklődési faktorral” is lemérnünk. Ennek érdekében mindhárom esetben elosztottam a nevek különböző rokoni kapcsolatokon át való öröklődésének az esetszámát a nemzetség férfineveinek összességével, majd összeadtam a három hányadost. A Hahót nemben például a 20 apa-fiú öröklődést elosztva a 112 névviselóvel 0,18-as öröklődési faktort kapunk. Ugyanezt elvégezve a nagyapa és a nagybáty esetében is, majd a három hányadost összegezve 0,27-et kapunk összesített öröklődési faktorként. A Bogátradvány nemzetségben 0,21 , a Tekele nemben pedig mindössze 0,13 lesz a végeredmény. Minél közelebb van a végső szám a 0 -hoz, annál kevésbé jellemző a nevek

${ }^{20}$ A zárójelben az előfordulás számát közlöm.

${ }^{21}$ A zárójelben az esetek számát közlöm. 
Örökítése, vagyis annál újítóbbnak tekinthető a nemzetség a névadás terén. A fenti számításból ennek alapján az derül ki, hogy bár a Tekele nemzetség létszámát tekintve a másik kettő között helyezkedik el, névadását tekintve mindkettőnél újítóbb; a Hahót nem pedig legkisebb létszáma mellett is a legerősebben őrizte a névadási hagyományokat.

Ráadásul ha nem nemzetségi, hanem alacsonyabb szinten vizsgálódunk, akkor az is kiderül, hogy az eddig bemutatott ismétlődések egyes nemzetségekben jellemzően csak egy-egy ágra vagy családra korlátozódnak. A Pongrác például kizárólag a Bogátradvány nemzetség cseleji ágán jelenik meg, vagyis az első Pongrácot követô nemzedékek 29 férfijából 4 e nevet viselte; igaz, nem apáról, hanem nagyapáról, dédapáról vagy oldalági rokonról örökölve. Azt is érdemes ugyanis figyelembe vennünk, hogy a közvetlen, apáról való, vagy pedig a közvetett, nagyapáról vagy oldalági rokonról való öröklés a jellemzőbb. Mint láttuk, ebben is a Hahót nemzetség bizonyult a legkonzervatívabbnak a kiugró mennyiségű apa-fiú névörökléssel, míg a másik két nemzetségben a közvetett öröklés volt a jellemzőbb.

Mindezek alapján arra a nem meglepő következtetésre juthatunk, hogy a korábbiaknál jóval óvatosabb állításokat lehet csak megfogalmazni a középkori nemzetségekre jellemző névöröklés mértékéről; egyrészt mert már a nemzetségek között is nagy eltérések lehetnek az inkább újító és az inkább hagyományőrző hozzáállásban, másrészt mert a nemzetségeken belül is nagy különbségek fedezhetők fel az egyes ágak között. Ez utóbbi könnyen érthető, hiszen a 14-15. századra az egyes ágak annyira elkülönültek egymástól a leszármazás révén, hogy sok esetben már nem lehet kikövetkeztetni a közös ősüket. Ebből pedig az következik, hogy a névadásban sokkal inkább lehet családi vagy „nemzetségági” hagyománnyal, mint nemzetségivel számolni.

Van azonban egy feltűnő egyezés a fenti eredményekben: a nevek megszakítatlan öröklése egyikben sem tartott tovább három generációnál (hacsak nem vesszük figyelembe a Hahót nembeli bizonytalan adatot). Habár található ennél hosszabb távú öröklődés is, a Tengerdi rokonság Rumi ágában például a Doroszló négy nemzedéken át öröklődött apáról fiúra, nyugodtan kijelenthető, hogy a férfinevek egyenes ági, megszakítatlan öröklődése átlagosan legfeljebb három-négy generációra terjedt ki. Ennek a névadási indítékok szúkebb családon belüli változása mellett a legfőbb oka az lehetett, hogy - mint FÜGEDI ERIK megállapította - a nemességben számos férfiág átlagosan éppen ennyi nemzedéket élt meg, mielôtt magva szakadt (vö. FÜGEDI 1974: 167).

A fenti vizsgálatok még egy szempontra felhívták a figyelmet: a három tárgyalt nemzetségből kettőben az öröklődő nevek között nem fordult elő a nemzetség névadójának az egyénneve. Ez azért különösen feltűnő, mert a történettudomány és a személynévtörténeti irodalom néhány ismert példa alapján evidenciaként kezeli azt, hogy az egyénnévből eredő nemzetségnevek gyakran ismétlődtek a nemzetségben. Ez kezdetben az ilyen nevú személyek nemzetséghez kötését is „megkönnyítette”, 
míg KUBINYI FERENC (1885a: 88-89) fel nem hívta a figyelmet e módszer veszélyére, vagyis arra, hogy az adott egyénnév nem csak az azonos nevú nemzetségben fordulhat elő. Erre korábbi munkámban magam is jó néhány példát említettem (SLíz 211b: 167-168). A fenti, három nemzetségen elvégzett vizsgálatok azonban arra indítottak, hogy a másik irányból is ellenőrizzem a fenti álláspont helytálló voltát: míg tehát korábban azt néztem meg, hogy egy adott nemzetség neve előfordul-e más családokban is, most azt követtem végig, hogy az egyes nemzetségekben hányszor fordul elő a nemzetség nevével részben vagy egészen megegyező egyénnév. Ennek során természetesen csak azokat a nemzetségeket vettem figyelembe, amelyeknek a neve világi egyénnévből származik, vagy legalábbis világi egyénnévként is létezett, és meg is jelent legalább egyszer a családfán. Kimaradt tehát a vizsgálatból például az Acsa, az Agmánd vagy az Ajtony nem, amelyek egy-két tábláján egyáltalán nem található meg a nemzetség neve egyénnévként. Az áttekintés során azt is figyelembe vettem, hogy hány generáción át ismétlődik egyenes ágon, megszakítatlanul az adott név, és hogy mikor bukkan fel utoljára a családfán. Ez utóbbinak a megállapításához a feltételezett születési időt, azaz a névadás idejét vettem alapul. Ennek meghatározásához a személy neve alatt szereplő, legelső oklevélbeli előfordulásra vonatkozó évszámot a családfán ábrázolt generációkhoz viszonyítva vettem figyelembe. Így sem volt lehetséges pontos születési év, sôt még évtized megadása sem, hiszen a legtöbb esetben nem lehet tudni a névviselőnek az említéskor betöltött korát; ezért csupán a több évtizedes, esetleg fél évszázados pontosságú időbeli besorolás bizonyult a legbiztosabb megoldásnak.

\begin{tabular}{|c|c|c|c|c|c|}
\hline Nemzetség & Egyénnév & $\begin{array}{l}\text { Előfordulás } \\
\text { (db) }\end{array}$ & $\begin{array}{c}\text { Egyenes ági } \\
\text { megszakítatlan } \\
\text { jelenlét } \\
\text { (generáció } \\
\text { száma) }\end{array}$ & $\begin{array}{c}\text { Utolsó } \\
\text { előfordulás } \\
\text { ideje }\end{array}$ & $\begin{array}{l}\text { Táblák } \\
\text { száma }\end{array}$ \\
\hline \multirow{2}{*}{ Hontpázmány } & Pázmány & 12 & 1 & 14. sz. 2. fele & \multirow{2}{*}{27} \\
\hline & Hont & 4 & 1 & 14. sz. 1. fele & \\
\hline Ákos & Akos & 11 & 1 & 15. sz. eleje & 13 \\
\hline Csák & Csák & 10 & 1 & 14. sz. 2. fele & 11 \\
\hline Osli & Osli & 6 & 4 & 14. sz. 1. fele & 8 \\
\hline Atyusz & Atyusz. & 5 & 4 & 13. sz. közepe & 1 \\
\hline \multirow{2}{*}{ Gútkeled } & Keled & 5 & 1 & 14. sz. eleje & \multirow{2}{*}{27} \\
\hline & Gút & 1 & 1 & 12. sz. vége & \\
\hline Héder & Héder & 5 & 1 & 14. sz. eleje & 6 \\
\hline Smaragdus & Smaragdus & 5 & 3 & 13. sz. közepe & 2 \\
\hline Aba & $A b a$ & 4 & 3 & 13. sz. 2. fele & 29 \\
\hline Becsegergely & Becse & 4 & 1 & 13. sz. vége & 5 \\
\hline Borics & Borics & 4 & 2 & 13. sz. 2. fele & 3 \\
\hline Csanád & Csanád & 4 & 1 & 13. sz. 2. fele & 6 \\
\hline
\end{tabular}


Egyénnevek

\begin{tabular}{|c|c|c|c|c|c|}
\hline Nemzetség & Egyénnév & $\begin{array}{c}\text { Előfordulás } \\
\text { (db) }\end{array}$ & $\begin{array}{c}\text { Egyenes ági } \\
\text { megszakítatlan } \\
\text { jelenlét } \\
\text { (generáció } \\
\text { száma) }\end{array}$ & $\begin{array}{c}\text { Utolsó } \\
\text { előfordulás } \\
\text { ideje }\end{array}$ & $\begin{array}{l}\text { Táblák } \\
\text { száma }\end{array}$ \\
\hline Gatal & Gatal & 4 & 2 & 13. sz. vége & 1 \\
\hline \multirow{2}{*}{ Kökényesradnót } & Rénold & 4 & 1 & 13. sz. 2. fele & \multirow{2}{*}{3} \\
\hline & Kökényes & 1 & 1 & 12. sz. vége & \\
\hline Baksa & Baksa & 3 & 1 & 14. sz. eleje & 10 \\
\hline Csolt & Csolt & 3 & 2 & 13. sz. 2. fele & 2 \\
\hline Hahót & Habót & $3(4 ?)$ & 3 & 13. sz. 1. fele & 5 \\
\hline Koppán & Koppán & 3 & 2 & 13. sz. közepe & 4 \\
\hline Rátót & Rátót & 3 & 1 & 14. sz. 2. fele & 11 \\
\hline Turul & Turul & 3 & 1 & 14. sz. eleje & 2 \\
\hline Szovárd & Szovárd & 3 & 1 & 15. sz. eleje & 3 \\
\hline Bogomér & Bogomér & 2 & 2 & 13. sz. 2. fele & 3 \\
\hline Gárdony & Gárdony & 2 & 2 & 13. sz. 1. fele & 1 \\
\hline Geregye & Geregye & 2 & 1 & 13. sz. 1. fele & 2 \\
\hline Győr & Györ & 2 & 1 & 14. sz. 2. fele & 6 \\
\hline Hermán & Hermann & 2 & 2 & 13. sz. vége & 5 \\
\hline Kaplyon & Kaplyon & 2 & 1 & 13. sz. 2. fele & 18 \\
\hline Tekele & Tekele & 2 & 1 & 13. sz. 2. fele & 6 \\
\hline \multirow{2}{*}{ Bogátradvány } & Bogát & 1 & 1 & 12. sz. 2. fele & \multirow{2}{*}{5} \\
\hline & Radvány & 1 & 1 & 13. sz. közepe & \\
\hline Borsa & Borsa & 1 & 1 & 13. sz. 2. fele & 7 \\
\hline Csór & Csór & 1 & 1 & 14. sz. eleje & 1 \\
\hline Gyovad & Gyovad & 1 & 1 & 14. sz. eleje & 2 \\
\hline Hánta & Hánta & 1 & 1 & 13. sz. közepe & 1 \\
\hline Szalók & Szalók & 1 & 1 & 13. sz. 1. fele & 6 \\
\hline Szentemágocs & Mágocs & 1 & 1 & 13. sz. 2. fele & 7 \\
\hline Szolnok & Szolnok & 1 & 1 & 13. sz. 2. fele & 1 \\
\hline Tomaj & Tomaj & 1 & 1 & 13. sz. közepe & 10 \\
\hline \multirow{2}{*}{ Zágrábkorpás } & Zágrábkorpás & 1 & 1 & 13. sz. eleje & \multirow{2}{*}{2} \\
\hline & Korpás & 1 & 1 & 12. sz. 2. fele & \\
\hline Zsidó & Zsidó & 1 & 1 & 13. sz. 2. fele & 4 \\
\hline
\end{tabular}

21. táblázat: A nemzetségnévvel részben vagy egészen megegyező egyénnév előfordulása az egyes nemzetségekben

A 21. táblázat áttekintéséből elsőként az válik nyilvánvalóvá, hogy az adott egyénnév ismétlődése a nemzetségeken belül egyáltalán nem tekinthető jellemző jelenségnek: még a hatalmas, 27 táblát kitevő, azaz 8-900 férfinevet tartalmazó Hontpázmány és Gútkeled nemzetségben is mindössze tizenkétszer, illetve ötször ismétlődik 
a nemzetségneveket alkotó egyénnevek közül a gyakoribb (azaz a Pázmány és a Keled). Egy másik összefüggés szintén világosan kirajzolódik a táblázat alapján: nem mutatkozik egyenes arányosság a nemzetség nagysága és az adott egyénnév gyakorisága között. A legnagyobb kiterjedésű (azaz a legtöbb ismert taggal rendelkező) Aba nemzetségben például mindössze négyszer, a szintén nagynak tekinthetô, tíz táblára kiterjedő Tomaj nemben pedig csupán egyszer fordul elố a tárgyalt egyénnév; ezzel szemben az Atyusz, név ötször ismétlődik a mindössze egyetlen táblából álló Atyusz nemzetségben. Az apáról fiúra való öröklődést tekintve ismét azt tapasztaljuk, hogy négy generációnál tovább nem terjed az öröklési lánc; meglepően nagy viszont azoknak a nemzetségeknek a száma, amelyekben az érintett egyénnév egyszer sem öröklődött apáról fiúra. Mindezek egyrészt alátámasztják a fentebbi, az egyes nemzetségek névadásában megnyilvánuló hagyománykövetési hajlandóságról szerzett tapasztalatokat, másrészt azt is egyértelművé teszik, hogy a nemzetség nevének egyénnévként való használata jóval kevésbé lehetett jellemző, mint azt korábban gondolni lehetett. És bár e névadásbeli hagyományőrzés vagy másképpen nézve a szimbólumértékú név választása az egyházi nevek egyre erősödő terjedése ellenében hatott, az is látható, hogy e hatás nem tekinthető különösebben erősnek, ráadásul időben előrehaladva egyre gyengült: az itt tárgyalt egyénnevek többsége az öröklődés és a szimbólumjelleg ellenére sem élte túl a 13. századot, a 15. század elejét pedig csupán kettő érte meg közülük: az Akos és a $S$ zovárd.

Persze egy-egy nemzetségben nem csupán a nemzetségnévvel azonos egyénnév ismétlődhet, mint azt fentebb a Hahót, a Bogátradvány és a Tekele nem kapcsán láthattuk. Több nemzetségben (illetve gyakrabban egy-egy ágban) is vannak olyan nem görög-latin eredetű nevek, amelyek kettőnél többszöri előfordulásukkal jellemzônek tekinthetők az adott nemzetségre, pl.

Aba: 5 Bodon, 4 Makján, 4 Kemény, 3 Becse;

Atyusz: 3 Bánd;

Básztély: 5 Rénold, 3 Osvát;

Becsegergely: 3 Apa;

Csolt: 3 Vata;

Héder: 8 Henrik;

Hontpázmány: 6 Ders;

Smaragdus: 3 Gilét;

Hahót: 4 Csák.

Mint látjuk, ezek egy része utalhat a nemzetség etnikai-nyelvi eredetére, mint a Héder nemben a német eredetû Henrik vagy a francia származású Smaragdus nemben a francia eredetű Gilét (a nemzetségek származására l. pl. FÜGEDI 1986: 13-14). Más részük azonban nem illik ebbe a képbe: ilyen a német eredetú Hontpázmány nemben a szláv eredetű Ders vagy a szintén német eredetű Hahót nemben a feltehetőleg 
szláv eredetű Csák. Ez megerősíti a korábban, három nemzetség leszármazási tábláinak áttekintésekor kapott eredményeket: a gyakori nevek eredete és a nemzetség származása között nem mutatható ki minden nemzetségre érvényes összefüggés.

A fenti listából még egy lényeges következtetés adódik. Mivel az itt látott nevek előfordulásainak a száma még a tízet sem éri el, a nemzetségre jellemző, azaz tipikus voltuk, ennélfogva pedig szimbólumként való múködésük nem gyakoriságukban keresendő, hanem abban, ahogy - a kognitív nyelvészet terminusait használva - figuraként kiemelkednek az országosan leggyakoribb, e nemzetségekben is tömegesen előforduló latin-görög eredetû nevek hátteréből.

\subsubsection{Az irodalmi eredetű egyénnevek vizsgálata az öröklődés szempontjából}

Számos irodalom- és történettudományi, valamint névtörténeti munka foglalkozott már a középkori magyar nemesség körében a lovagi kultúra hatására divatjelenségként megjelenő irodalmi eredetű nevekkel. A korai névtudományi munkák nem léptek túl a névdivat létezésének jelzésén, illetve néhány példa bemutatásán. E névcsoport elsô részletes, számos szempontra kiterjedő névtudományi vizsgálata KOROMPAY KLÁRA 1978-as munkája volt a Roland-ének nevei kapcsán, majd történettudományi szempontból, de a névkutatás számára is megkerülhetetlen eredményekkel - KURCZ ÁGNES (1988: 246-251) tekintette át részletesen a kérdést. Azóta több, egy-egy névpárt, illetve mûvet érintő, mélyfúrás jellegű elemzés, valamint a névcsoport és a mögöttük lévő névadási indítékok jellemzőit feltáró áttekintés is született (KOROMPAY 2008, 2011, 2012; SLÍZ 2011b: 162-166, 2012b, 2016a).

A következőkben egy eddig még részletesen nem tárgyalt szempontból, a névöröklés felől közelítem meg a kérdést. Első lépésként a már említett forrásból, az ENGEL-féle genealógiából (2003) kigyújtöttem az irodalmi eredetú neveket, immár nemcsak a nemzetségekre, hanem az összes nemesi családra vonatkozólag (22. táblázat). KOROMPAY KLÁRA (1978) és KURCZ ÁGNES (1988) korpuszában, valamint a saját gyüjtésemben számos további név és névviseló is szerepel a nemességből és néhány esetben az alsóbb rétegekból is, ezeket azonban most nem vehettem figyelembe, hiszen az öröklődés vizsgálatához családfákra volt szükségem. A korábbi fejezetektôl eltérően itt mindkét nem neveit vizsgáltam, mivel e nevek felbukkanása a családfán nemcsak önmagában, hanem más nevekre vonatkoztatva is fontos eredményekre vezethet. A neveket az ellenőrizhetőség érdekében abban a formában adom meg, amelyben a genealógiában leggyakrabban szerepelnek.

A 22. táblázatot a férfinevek öröklődése kapcsán kapott eredményekkel összevetve megállapíthatjuk, hogy az irodalmi eredetú nevek nemzetségen vagy családon belüli öröklődése némileg kevésbé volt jellemző, mint a világi egyénneveké. Bár e névcsoport nem nevezhető különösebben nagy súlyúnak, azaz eleve kevesebb 
névegyeddel kell számolnunk, mégis feltűnő, hogy a legtöbb esetben mindössze egyetlen előfordulást tudunk igazolni egy adott családon belül. Az egyenes ági, megszakítatlan öröklés is ritka, és mindössze egyetlen esetben terjed ki három nemzedékre. Ez még a leggyakoribbnak tûnő Loránd esetében is igaz. Ez ugyan hétszer is előfordul a Rátót nemzetségben, de nem ugyanazon szúkebb családon belül, hanem négy ágra kiterjedve.

\begin{tabular}{|c|c|c|c|c|c|}
\hline Forrás & Egyénnév & $\begin{array}{l}\text { Nemzetség, } \\
\text { család }\end{array}$ & $\begin{array}{l}\text { Előfordulás } \\
\text { (db) }\end{array}$ & $\begin{array}{c}\text { Egyenes ági } \\
\text { megszakítatlan } \\
\text { jelenlét } \\
\text { (generáció száma) }\end{array}$ & $\begin{array}{c}\text { Utolsó } \\
\text { előfordulás } \\
\text { ideje }\end{array}$ \\
\hline \multirow{11}{*}{$\begin{array}{l}\text { Trója-regény, } \\
\text { klasszikus } \\
\text { irodalom }\end{array}$} & \multirow{3}{*}{ Ehellös } & $\begin{array}{l}\text { Ákos nb. } \\
\text { Torockói ág }\end{array}$ & 4 & (l) & 14. sz. vége \\
\hline & & $\begin{array}{l}\text { Hontpázmány } \\
\text { nb. Ugocsai ág }\end{array}$ & 3 & 1 & 13. sz. közepe \\
\hline & & $\begin{array}{l}\text { Divék nb. } \\
\text { Akor-ág }\end{array}$ & 2 & 2 & 14. sz. eleje \\
\hline & \multirow{3}{*}{ Hektor } & Laki család & 2 & 2 & 13. sz. 2. fele \\
\hline & & Gárdony nb. & 1 & 1 & 13. sz. vége \\
\hline & & Tomaj nb. & 1 & 1 & 13. sz. 1. fele \\
\hline & \multirow[b]{2}{*}{ Páris } & Herény nb. & 2 & 1 & 14. sz. 1. fele \\
\hline & & $\begin{array}{l}\text { Csabi nb. } \\
\text { Reszneki ág }\end{array}$ & 1 & 1 & 14. sz. 2. fele \\
\hline & Polixena & $\begin{array}{l}\text { Básztély nb. } \\
\text { Rozgonyi ág }\end{array}$ & 1 & 1 & 15. sz. 1 . fele \\
\hline & Galatya & Antimus család & 1 & 1 & 13. sz. 1 . fele \\
\hline & Médea & $\begin{array}{l}\text { Káta nb. } \\
\text { Dengelegi ág }\end{array}$ & 1 & 1 & 15. sz. 1. fele \\
\hline \multirow{8}{*}{$\begin{array}{l}\text { Trisztán és } \\
\text { Izolda }\end{array}$} & \multirow{4}{*}{ Terestény } & $\begin{array}{l}\text { Divék nb. } \\
\text { Akor-ág }\end{array}$ & 2 & 2 & 13. sz. vége \\
\hline & & $\begin{array}{l}\text { Hahót nb. } \\
\text { Buzád-ág }\end{array}$ & 1 & 1 & 13. sz. eleje \\
\hline & & $\begin{array}{l}\text { Ják nb. } \\
\text { Rába-balparti } \\
\text { föág, Csuna-ág }\end{array}$ & 1 & 1 & 13. sz. eleje \\
\hline & & $\begin{array}{l}\text { Tekele nb. } \\
\text { Roskoványi } \\
\text { család }\end{array}$ & 1 & 1 & 15. sz. 1. fele \\
\hline & \multirow{4}{*}{ Isalt } & $\begin{array}{l}\text { Bogátradvány } \\
\text { nb. Rákóci ág }\end{array}$ & 1 & 1 & 13. sz. vége \\
\hline & & Helmeci család & 1 & 1 & 14. sz. 1. fele \\
\hline & & $\begin{array}{l}\text { Nádasd nb. } \\
\text { Oszkói ág }\end{array}$ & 1 & 1 & 13. sz. vége \\
\hline & & $\begin{array}{l}\text { Rátót nb. } \\
\text { Putnoki ág }\end{array}$ & 1 & 1 & 14. sz. eleje \\
\hline \multirow{2}{*}{ Roland-ének } & \multirow{2}{*}{ Loránd } & Rátót nb. & 7 & 2 & 14. sz. közepe \\
\hline & & Treutel-rokonság & 3 & 3 & 14. sz. 2. fele \\
\hline
\end{tabular}




\begin{tabular}{|c|c|c|c|c|c|}
\hline & & Csém nb. & 2 & 2 & 13. sz. eleje \\
\hline & & $\begin{array}{l}\text { Péc nb. } \\
\text { Zalai ág }\end{array}$ & 2 & 2 & 14. sz. eleje \\
\hline & & $\begin{array}{l}\text { Ákos nb. Mikcs } \\
\text { ága, Mikcsfi }\end{array}$ & 2 & 1 & 14. sz. eleje \\
\hline & & $\begin{array}{l}\text { Dobák } \\
\text { rokonsága }\end{array}$ & 2 & 1 & 14. sz. 2. fele \\
\hline & & $\begin{array}{l}\text { Gútkeled nb. } \\
\text { Sárvármonostori } \\
\text { ág, Ráskai család }\end{array}$ & 2 & 1 & 14. sz. 2. fele \\
\hline & & $\begin{array}{l}\text { Kéri rokonság, } \\
\text { Bajánházi ág }\end{array}$ & 2 & 1 & 14. sz. közepe \\
\hline & & $\begin{array}{l}\text { Komlósi } \\
\text { rokonság }\end{array}$ & 2 & 1 & 14. sz. 1. fele \\
\hline & & Tomaj & 1 & 1 & 13. sz. vége \\
\hline & & $\begin{array}{l}\text { Ják nb. } \\
\text { Rába-balparti } \\
\text { föág, Csuna-ág }\end{array}$ & 1 & 1 & 14. sz. eleje \\
\hline & & Gárdony nb. & 1 & 1 & 14. sz. 1. fele \\
\hline & & $\begin{array}{l}\text { Csabi nb. } \\
\text { Reszneki ág }\end{array}$ & 1 & 1 & 14. sz. 2. fele \\
\hline & & Rátót nb. & 4 & 1 & 14. sz. 2. fele \\
\hline & Olivér & $\begin{array}{l}\text { Csabi nb. } \\
\text { Reszneki ág }\end{array}$ & 3 & 1 & 14. sz. 1. fele \\
\hline & & Ugra nb. Ugrai & 2 & 2 & 14. sz. közepe \\
\hline & & Aba nb. Rédei ág & 2 & 1 & 14. sz. eleje \\
\hline & Lancret & Antimus család & 1 & 1 & 13. sz. 1. fele \\
\hline Artúr- & Weniwer & Atyusz nb. & 1 & 1 & 12. sz. vége \\
\hline mondakör & Enid & $\begin{array}{l}\text { Szalók nb. } \\
\text { Kerecsenyi ág }\end{array}$ & 1 & 1 & 14. sz. eleje \\
\hline $\begin{array}{l}\text { Nagy Sándor- } \\
\text { regény }\end{array}$ & Olimpias & Pok nb. & 1 & 1 & 13. sz. 1. fele \\
\hline
\end{tabular}

22. táblázat: Irodalmi eredetű nevek a nemesség körében ENGEL (2003) alapján

Ez azért különösen meglepő eredmény, mert a korábbi szakirodalom szerint e névcsoport divatjának fő idôszaka a 13-14. század, és a 15. század elejére már inkább csak az öröklődés tartotta fenn egy-két példányukat (1. pl. KuRCZ 1988: 250). Ehhez képest a 14. század második felében vagy a 15. század elején adott nevek között jórészt olyanokat találunk, amelyeknek (legalábbis a forrásként használt genealógia szerint) nincsen családi-nemzetségi előzményük: Loránd és Páris a Csabi nb. Reszneki ágon, Médea a Káta nb. Dengelegieknél, Polixena a Básztély nb. Rozgonyiaknál, Terestyén a Tekele nb. Roskoványiaknál. Ez pedig arra enged következtetni, hogy e névtípust nem csupán az öröklés, hanem feltehetőleg a források ismerete is éltette a 15. század elejéig. 
KOROMPAY KLÁRA 1978-as munkája óta bevett módszertani elv az, hogy az irodalmi eredetú neveket párokban, illetve csoportban érdemes vizsgálni, ha a célunk annak kimutatása, hogy a névadó szülők ismerhették-e a forrásul szolgáló lovagi irodalmat. A névöröklés szempontjából ez a módszer szintén segítségünkre lehet, amennyiben nem csupán a példány-, hanem a típusgyakoriságra is figyelmet kívánunk fordítani. Az említett neveket együtt vizsgálva már az örökítés némileg nagyobb jelentősége rajzolódik ki előttünk. Így a szakirodalomban méltán a leggyakrabban említett (1. pl. VAJAY 1968: 334-335, KOROMPAY 1978: 78), az öröklés szempontjából a legkiemelkedőbb Rátót nemben az idősebb Loránd nádor az ifjabbnak a nagybátyja volt; az idősebb Loránd nádor testvére az Olivér nevet viselte, és a nádor unokáit is Loránd-nak és Olivér-nek hívták; ez utóbbi Olivérnek a fia szintén Loránd volt, ez utóbbi Lorándnak a dédunokája pedig ismét Olivér (Paksi ág). Továbbá az idősebb Loránd nádor egyik unokaöccsének az unokája is Loránd (Kakaság), egy másik unokaöccsének a fia pedig Olivér volt (Tari ág). Az ifjabb Loránd nádor fia is a Loránd nevet kapta (Jolsvai ág), és e nádor testvérének a dédunokája is Loránd lett (Serkei ág). E két név együttes megjelenése, amint azt az említett mûvek (VAJAY 1968: 334-335, KOROMPAY 1978: 78) is kiemelik, bizonyára a Rátót nemzetség normann eredetével, családi hagyományaival állhat kapcsolatban. Az azonban feltűnő, hogy a Loránd többször jelenik meg a családfán, mint az Olivér. Országosan is hasonló arányokat tapasztalunk (vö. KOROMPAY 1978: 26-44, SLíz 2011b: 164), vagyis a Loránd az Árpád- és az Anjou-kor folyamán is népszerúbb volt az Olivér-nél (ami nem meglepő, hiszen ő az ének főhőse, emellett a lovagi bátorság, hősiesség szimbóluma). Ennek ellenére az adott esetben, úgy vélem, a Loránd nagyobb megterheltségéhez az is nagyban hozzájárult, hogy első viselője nádor volt, majd a feltehetőleg róla elnevezett unokaöccse is elérte a legmagasabb méltóságot, amit egy arisztokrata betölthetett, így nevük a család nagyságának egyfajta szimbólumává vált.

Bár ennyire szövevényes névöröklési viszonyokra másutt nem találunk példát, azért több esetben is felfedezhetôk hasonló kapcsolatok a névviselők között. A Divék nb. Akor-ágon például két Ehellös-t és két Terestény-t találunk, mindkettőt apa-fia viszonyban, ráadásul az idősebb Terestény az idősebb Ehellős nagybátyja volt. A Hahót nb. Buzád-ág a Rátótokhoz hasonlóan már korán felkeltette a kutatók figyelmét a Terestény, Lancret és Yven testvérhármassal (az utóbbi ENGELnél nem szerepel) (1. pl. PAIS 1932, MOÓR 1937: 63, KURCZ 1988: 248). A Csabi nb. Reszneki ágon szintén kedveltek lehettek az irodalmi eredetű nevek: a középső Olivér az apjáról, a legifjabb pedig szintén az első Olivérről, az ükapjáról örökölhette a nevét; a legifjabb Olivér egyik nagybátyja viselte a Páris nevet, a középső Olivér testvérének az unokája pedig a Loránd-ot. A Ják nb. Rába-balparti fóágban, Csuna ágán Terestény egyik unokája viselte a Loránd nevet. A Gárdony nb. Hektornak az unokaöccse volt Loránd, a Tomaj nemben pedig az említett Hektor másod-unokatestvérének az egyik fiát hívták Loránd-nak. Az Antimus családbeli Galatyának az unkatestvére volt Lancret. 
Már e felsorolásban, különösen a Rátótok kapcsán is látható volt, hogy e nevek öröklésében jellemzőbbnek mutatkozik a nem egyenes ági örökítés. Így a Herény nemzetségbeli második Páris a nagyapjáról kaphatta a nevét, ahogyan a Gútkeled nem Sárvármonostori ágához tartozó Ráskai családbeli és a Kéri rokonság Bajánházi ágán szereplő két-két Loránd között is e rokonsági fokot fedezhetjük fel. Nagybátyunokaöcs viszony volt az Ákos nb. Mikcs-ág Mikcsfi alágán és a Komlósi rokonságban is a két-két Loránd között, továbbá ugyanilyen kapcsolat kötötte össze az Aba nb. Rédei ág két Olivérjét is.

A fentiek alapján úgy tűnik, hogy bár az irodalmi eredetű nevek egyedeinek öröklése, különösen egyenes ágon nem nevezhető jellemzőnek, magának a névtípusnak az öröklődése, illetve együttes megjelenése némileg nagyobb gyakorisággal fordult elő. Ez pedig arra enged következtetni, hogy a korabeli névadók - legalábbis azokban a családokban, amelyekben az öröklődést, illetve együttes előfordulást ki lehet mutatni - tisztában lehettek e nevek irodalmi eredetével és összetartozásával. 



\section{MEGKÜLÖNBÖZTETŐ NÉVELEMEK ÉS CSALÁDNEVEK}

\subsection{Formai szempontok alkalmazhatósága a történeti családnevek vizsgálatában}

\subsubsection{Az alapkérdés}

A magyar személynévtörténeti kutatások egyik központi kérdése a családnevek kialakulásának ideje. Számos, egymástól gyakran eltérő vélemény él ezzel kapcsolatban; a két legszélső időmegjelölés a 13. és a 18. század (az előbbire 1. MELICH 1943: 271, az utóbbira MEZŐ 1970: 28). E nagy különbségre több okot is találhatunk. Az egyik terminológiai: egyrészt egyes kutatók a kialakulás-on a több évszázados folyamat kezdetét, a családnevek előzményének tekinthető, még nem öröklődő megkülönböztető névelemek megjelenését, mások viszont a végét, a névrendszer teljessé válását és megszilárdulását értették. Másrészt a családnév terminus értelmezése sem egységes: mára konszenzus alakult ki arról, hogy csak az öröklődő névelem tekinthetô családnévnek, korábban azonban MELICH (1943) még a nem öröklődő megkülönböztető elemeket is családnévként fogadta el. További, immár nem terminológiai, hanem kutatásmódszertani probléma, hogy az öröklődés igen nehezen mutatható ki megfelelő mennyiségü, a névviselő család több generációját dokumentáló forrás(ok) hiányában.

Az öröklődés mint kritérium mellett (általában látens módon) formai szempontok is jelentkeznek a szakirodalomban, jellemzően nem elméleti, hanem gyakorlati szinten, vagyis akkor, amikor el kell dönteni, hogy egy névelem már családnévnek tekinthetô-e. Így például FEHÉRTÓI KATALIN a de + helyneves szerkezetet (pl. de Buda) még nem tartotta családnévnek: csak a magyaros formában leírt, -i helynévképzős alakokat (pl. Budai) fogadta el valódi családnévként (FEHÉRTÓI 1969: 33). Ugyanő a latin és magyar nyelven feljegyzett, általában dictus-szal kapcsolt megkülönböztető névelemek kapcsán (pl. 1343: Nicolaum dictum Zeuke, AO. 4: 302) arra a következtetésre jutott, hogy a rufus-t, magnus-t stb. azért használták gyakrabban, mint a veres/piros-t és a nagy-ot, mert az előbbiek még csak a személy esetleges, nem állandó jelölői voltak, és valódi tulajdonságra utaltak, az utóbbiakat viszont ,akkor használhatták, amikor az elem már jobban hozzátapadt a személyhez, állandóbbá vált, a későbbiekben öröklődött is" (FEHÉRTÓI 1969: 9). Erre azonban semmilyen bizonyítékot 
nem hozott fel, holott az állandóságot szerencsés esetekben lehet igazolni az ugyanazon személyre vonatkozó adatok összevetésével.

Valójában az efféle formai szempontok (konkrétan: a lejegyzés nyelve, a névelemek száma és sorrendje), mint azt a következőkben különböző korú és típusú források összevetésével igyekszem bemutatni, alkalmatlanok a családnévség megitélésére, mivel a források személyjelölő szerkezetei inkább a nevek feljegyzésére latin minták alapján kialakult szokásokat tükrözik, s csak kevésbé, illetve áttételesen a valós élószóbeli névhasználatot.

\subsubsection{4. századi oklevelek és 16. századi összeírások személyjelölő szerkezeteinek összevetése: 1 . vizsgálat}

A történeti tudományok eredményei alapvetően függenek attól, milyen források állnak rendelkezésükre. A magyar személynévtörténeti kutatás a 14. század legnagyobb részére vonatkozóan a társadalom világi tagjairól sajnálatos módon szinte kizárólag egy típusú forrással, szorosabb értelemben vett birtok- vagy egyéb jogi ügyekkel foglalkozó oklevelekkel (adomány-, osztály- és ítéletlevelekkel, szerződésekkel, tanúvallomásokkal, végrendeletekkel, határjáró oklevelekkel stb., továbbá a jogi eljáráshoz kapcsolódó egyéb iratokkal) rendelkezik. Ezekből a nagy számban rendelkezésre álló, összefüggő szövegként felépülő oklevelekből csak viszonylag hosszú ideig tartó munkával lehet kinyerni a korpusz alapját képező neveket. A korábbi és a későbbi időszakból viszont ezek mellett összeírások is maradtak fenn. Ez utóbbiak nagy tömegben, listaszerúen tartalmaznak neveket, melyeket szinte csak be kell sorolni a megfelelő, a vizsgálat céljainak megfelelően kialakított kategóriákba, és máris lehet velük számításokat végezni. Ezért például a 16. századra vonatkozóan mind ez idáig elsősorban az összeírások szolgáltak a névtani kutatások alapjául (kivételként említhető N. FODOR 2010). Ebből következőleg a családnevek kialakulásának történetét vizsgálva a 14. és a 16. századból csak eltérô típusú források névadatai alapián levonható következtetésekre tudunk támaszkodni. Vessük tehát össze a 14. századi oklevelekben szereplő névadatok formai viselkedését a 16. századi összeírásokban találhatókéval.

A 14. századi oklevelek személyjelölő szerkezeteiben az egyénnévhez kapcsolódó megkülönböztetô névelemek megjelenése négy alaptípussal írható le: 1 . valamely rokon egyénneve (általában az apa neve filius-szal vagy anélkül), 2. de + helynév (de nélkül is), 3. a névviselő egyéb tulajdonságát vagy körülményeit jelölő névelem (dictus-szal vagy anélkül), 4. nemzetségnév (de generé-vel vagy de generacioné-val). Ezeket az alábbiakban röviden filius-szal, de-vel, dictus-szal és de generé-vel jelölöm. A csak 1-1 névelemet tartalmazó szerkezetek (pl. Stephanus filius Petri) mellett az alábbi, bonyolultabb kombinációk fordulnak elő az összesített, 1301-1359 közötti korpuszban: 
- filius + filius: pl. 1348: Georgius filius Ladislai filii Abram (AO. 5: 224)

- filius + filius + filius: pl. 1334: Johannes filius Salamonis filii Ekch filii Elek (AO. 3: 88)

- filius + de: pl. 1348: Paulus filius Johannis de Luka (AO. 5: 225)

- filius + filius + de: pl. 1348: Ladislaus filius Thome filii Ders de Zuba (AO. 5: 252)

- filius + de genere: pl. 1347: Thomas filius Aladarii de genere Peech (AO. 5: 44)

- filius + filius + de genere: pl. 1304: demetrio filio Ladyzlai filij Kustan de genere papa (AO. 1: 86)

- filius + dictus: pl. 1347: contra Nicolaum filium Johannis dictus Cynege (AO. 5: 79)

- dictus + filius + filius: pl. 1332: Petrus dictus Zenke filius Nicolai filii Jacobi (AO. 2: 631)

- dictus + filius + filius + filius: pl. 1324: Johannes dictus Lengen filius magistri Stephani filii Michaelis filii Wbul (AO. 2: 171)

- dictus + de: pl. 1343: Dominicus dictus Santus de Egerzegh (AO. 4: 312)

- dictus + de genere: pl. 1327: comitis Stephani dicti Purch de genere Ratolt (AO. 2: 339)

- de + de genere: pl. 1339: Endre de Bors de genere Sartyuanueze (AO. 1: 497-498)

- filius + de + de genere: pl. 1321: Comes Ladizlaus filius Alexandri de Manaky de genere Bogathrodwan (AO. 1: 617)

- filius + filius + de + de genere: pl. 1318: Johanne filio Pauli filij Lukus de Banky de genere buntpazman (AO. 1: 456-457)

- filius + filius + filius + de genere: pl. Johannes Nicolaus Stephanus et Emericus filii Emerici, filii Pauli filii Kompoltby de genere Aba (AO. 5: 510)

- filius + filius + filius + de genere + de: pl. 1336: magister Beke filius Thome filii Benedicti filii Iwanka de genere Sudan de Velyke (AO. 3: 246)

- dictus + filius + de genere: pl. 1338: nobili viro magistro Stephano dicto Pagan ['Pagan'] filio Francisci de genere Hunthpaznan (AO. 3: 470)

- filius + dictus + de: pl. 1337: Nicolaus filius Michaelis dicti W klelen de Byky (AO. 3: 351)

- filius + filius + dictus + de: pl. 1337: magister Dionisius dictus Magar filius Simonis filii Chalk de Rhedey (AO. 3: 373)

Ezeknek a kombinációknak természetesen eltérő sorrendû variációi is előfordulnak az oklevelekben. Ráadásul ugyanazt a személyt nemcsak különböző névelemekből összeálló szerkezetekkel lehet megnevezni az írásbeliségben, hanem úgy is, hogy egyszer szerepel az egyénnév mellett megkülönböztetô névelem, másszor nem.

E rendkívüli változatossággal szemben a 16 . századi összeírásokban szinte kivétel nélkül kételemúek a nevek; elöl áll a latinul feljegyzett egyénnév, ezt pedig minden latin kiegészítő nélkül követi a magyar nyelvű megkülönböztető elem: Laurencius Anthal, Thomas Zalay, Paulus Kys stb. (VeszprUrb. 45). (A nemzetségnév ekkorra eltűnik, 
ugyanis a nemzetségek a 14. század közepére jórészt felbomlottak, illetve az ágaik, családjaik közti összetartozás a birtokviszonyok átalakulása miatt fellazult; habár az egy nemzetségből kiváló családok még a 15. században is számon tartották vérségi összetartozásuk emlékét; vö. FÜGEDI 1974: 177.) Ezek a szerkezetek már nagyon hasonlók a mai hivatalos teljes nevekhez, eltekintve a latinos névsorrendtől és az egyénnevek latin nyelvű közlésétól.

A két korszak személyjelölő szerkezeteit formai alapon összehasonlítva tehát arra a következtetésre juthatunk, hogy a 14. században még nem voltak családnevek, hiszen az egyénnév mellett álló névelemekből egyszerre több is lehetett, és ezek meglehetősen változékonyak voltak. A 16. században azonban már feltehetôleg léteztek családnevek, hiszen a személyjelölő szerkezetek már csak kételeműek, és az egyénnév mellett álló névelemek a 14. századiaktól eltérően, azaz az élőszóbeli használatot tükrözve már következetesen magyarul jelennek meg, holott az egyénnevek még ekkor is az írásbeliségben megszokott módon, latin változatukban szerepelnek a forrásban.

\subsubsection{4. századi oklevelek és az 1332-1337-es pápai tizedjegyzékek névadatainak összevetése: 2 . vizsgálat}

A 14. századról a fentinél árnyaltabb képet kaphatunk, ha az említett oklevelek névadatait összevetjük az 1332-1337-ből fennmaradt pápai tizedjegyzékek személyjelölő szerkezeteivel. Az ezekben szereplő nevek viselőinek társadalmi státusa jelentősen eltér az említett oklevéltípusokban találhatókétól, hiszen míg a birtok- és egyéb jogi ügyek kapcsán nagyobbrészt (bár nem kizárólag) világiak neveivel találkozunk, ezekben egyházi személyek szerepelnek.

A pápai tizedjegyzékekben az egyénnevek többségéhez annak a településnek a nevét kapcsolták de-vel, amelynek a névviselő a papja volt. E névadatok ezért feltehetőleg nem élószóbeli névhasználatot tükröznek, és nem tekinthetők helynévi eredetű megkülönböztető névelemes szerkezeteknek, csupán körülírásoknak: nem azt fejezik ki ugyanis, hogy a pap az adott településről származik, vagy birtoka van ott, csupán azt jelzik, hol végzi szolgálatát. Az adatok túlnyomó részében így nem találunk megkülönböztetô névelemet. Ebből azonban tévedés lenne arra következtetnünk, hogy az egyháziaknál később alakult ki a családnév, mint a világiaknál. Ez már logikailag sem lehetne helyes, hiszen az ember az egyházba nem beleszületik, hanem belép, elhagyva családját, melybe született, esetleg családnevével együtt, melyet családjától örökölt. Ezt bizonyítja egyrészt az a néhány megkülönböztető névelem, amely fel-felbukkan a forrásban: Michael filius Andriel (PT. 169), Petrus filius Habrabe (PT. 173), Meta dictus Pobo iuratus (PT. 200), Cosmas Rufus (PT. 272), Andreas sacerdos Niger (PT. 282). Másrészt szintén ezt támasztják alá azok az esetek is, amikor egy egyházi személy neve valamely ôt érintő birtokügyben kerül be egy oklevélbe. Ilyenkor az ő egyénneve mellett is megjelennek a világiaknál tapasztalt 
megkülönböztető névelemek: domino Ladislao sacerdoti filio Benedicti de Pezeren (1348; AO. 5: 166), discretus vir dominus Ladislaus filius Thome filii Ders de Z uha, nunc prepositus ecclesie Sancti Georgii martiris de Strigonio (1348, AO. 5: 252). Annak tehát, hogy a tizedjegyzékben csak elhanyagolható arányban szerepelnek megkülönböztetô névelemek, inkább az lehet az oka, hogy egy egyházi személy esetében nem a családja, birtoka vagy valamely külső-belső tulajdonsága, hanem az egyházban betöltött funkciója a lényeges. Mindebből pedig azt a következtetést vonhatjuk le, hogy egyrészt a névviselők társadalmi helyzete is befolyásolja nevük írásban megjelenő változatának szerkezetét, másrészt viszont a forrás célja és típusa is.

\subsubsection{Három 16. századi forrástípus névadatainak összevetése: 3. vizsgálat}

A 16. század kapcsán szerencsésebbek vagyunk, mert több forrástípus is a rendelkezésünkre áll, ezért a továbbiakban ez az idôszak kerül a vizsgálat fókuszába. Hogy kiderítsük, helyes-e a fenti következtetés, vagyis hogy a forrástípus is befolyásolja a névadat szerkezetét, vessük össze a személyjelölő szerkezeteket három, hozzávetőleg azonos időben, de eltérő céllal készített forráscsoportban: A) szorosabb értelemben vett birtok- és egyéb jogi ügyekkel kapcsolatos oklevelekben, B) összeírásokban, C) számadáskönyvekben.

A) Szorosabb értelemben vett birtok- és egyéb jogi ügyekkel foglalkozó oklevelek. E forráscsoport vizsgálatához N. FODOR JÁNOS Északkelet-Magyarország területéről származó korpuszának (FTSznSz.) 1500-1526 közötti anyagából kiválogattam az e típusba tartozó okleveleket. Ezekben összesen 94 nemes neve fordul elő, a következő szerkezetekben:

1. de: $37,2 \%$, pl. Johannes de Thorda (1523)

2. helynév: $19,1 \%$, pl. Andrea B a th o ri (1523)

3. körülírás: 18,1\%, pl. 1520: condam Sebastiani et Johannis de Wüfalws filiorum condam Domine Dorothee filie olim Andree de Ibran (1520)

4. egyéb tulajdonság: 7,4\%, pl. Michaelis ff ark as (1515)

5. egyéb tulajdonság + de: $7,4 \%$, pl. Egregii Johannis $W \ddot{j}$ the z de Kallo (1525)

6. apanév + de: 5,3\%, pl. Ladislaum Ge de de Ew zedfalwa (1523)

7. helynév + de: 5,3\%, pl. Ladislao perkedy de Bolth (1525)

Mint látjuk, ekkorra három, a 14. században még meglévő latin névkiegészítő eltűnt (filius, dictus, de genere). Fennmaradt viszont a de, amely azonban részben más funkciót kapott. Továbbra is jelzi a nemes birtokát, de már egy korábban, azonos eredetű megkülönböztető névelemből kialakult elemhez (1. 7. csoport: perkedj) is képes újabb helynévi eredetủ névelemet kapcsolni (vö. 7. csoport: de Bolth). Emiatt 
az a gyanúnk támadhat, hogy a magyar formánssal feljegyzett helynévi eredetú elem (perkedji) már családnév, azaz öröklött, nem feltétlenül valós birtoklást jelző névelem lehet. Ezzel szemben a de-vel bevezetett elem valóban a névviselő meglévő birtokára utal, vagyis nem feltétlenül része az élőnyelvi névhasználatnak, csupán a nemesi nevek feljegyzésének szokásos formai követelményét teljesíti.

A variációk száma és bonyolultsága ekkorra láthatólag csökkent a 14. századiakhoz képest, de még mindig viszonylag nagy változatosságnak lehetünk tanúi. A névszerűséget skalárisan felfogva a lehetőségek közül formailag a legnévszerúbbek a latin elem nélküliek (2. és 4. csoport), ezek 26,5\%-ot tesznek ki; kevésbé névszerúek a latin elemet tartalmazók (1., 5., 6. és 7. csoport), ezek aránya együttesen 55,2\%; a legkevésbé névszerúek pedig a körülírások (3. csoport), melyek az adatok 18,1\%-ában fordulnak elő. Ha tehát pusztán formai alapon döntünk, azt kell mondanunk, hogy a 16. századi írott személyjelölő szerkezetek már jóval névszerúbbek a 14. századiaknál, de még mindig csak kisebb részükben $(26,5 \%)$ fedezhetünk fel teljes bizonyossággal családnevet.

B) Ö́sszeírások. Ugyanebből az időszakból több jobbágyösszeírás is fennmaradt. E források szövegük szerkezetében és létrehozásuk céljában is különböznek az elóbbi típusú oklevelektől. Az összeírás valamiféle felsőbb hatalom utasítására és további használatára készül, a szúkebben vett birtok- és egyéb jogi ügyekkel foglalkozó oklevelek ezzel szemben többnyire egyes (hivatalos vagy magán-)személyek ügyeivel kapcsolatosak. Emellett a birtokügyekkel foglalkozó oklevelekben a jobbágynevek kisebbségben vannak, a korabeli összeírásokban viszont jellemzően ők jelennek meg mint adóalanyok. Míg a nemes szempontjából fontosak családi kapcsolatai és birtokviszonyai, addig egy jobbágy esetében az előbbiek nem számítanak a felsőbb hatalom számára, az utóbbiak pedig többnyire nem léteznek. Ráadásul a birtokügyekkel foglalkozó oklevelek gondosan megszerkesztett szövegek, az összeírások viszont alig többek a nevek és a fizetendő összegek puszta felsorolásánál.

E különbségek mind szerepet játszanak abban, hogy az összeírásokban szereplő személyjelölő szerkezetek, mint azt a veszprémi püspökség urbáriumának a példáján láthattuk, formailag jóval egyszerúbbek és egységesebbek a birtokügyeket tárgyaló okleveleknél: latin névkiegészítőt egyáltalán nem tartalmaznak, és mindig kételeműek. Ha tehát pusztán e két 16. századi forrástípus névadatainak formai megítélése alapján döntünk, arra kell következtetnünk, hogy a jobbágyok körében a 16. század első felére már valószínúleg kialakultak a családnevek, a nemeseknél azonban még javában tart ez a folyamat. Ez azonban ellentmond annak az általános tapasztalatnak, hogy az új szokások, különösen a divatjellegú változások általában a társadalom felsőbb rétegeiből kiindulva terjednek az alsóbb rétegek felé. Ráadásul a veszprémi püspökség urbáriumában egyházi nemesek is szerepelnek, akik társadalmilag a nemesség és a jobbágyság között állnak. Mivel pedig a rájuk vonatkozó személyjelölő szerkezetek is ugyanolyanok, mint a jobbágyokéi (pl. Anthonius Kys nobilis ecclesie; VeszprUrb. 35), biztosak lehetünk benne, hogy az eltérô forma nem pusztán a 
társadalmi rétegek, hanem a forrástípusok eltéréséből adódik. Ezért tehát az a következtetés, hogy a jobbágyok körében hamarabb alakult ki a családnév, mint a nemesség körében, nem meglepő módon nemigen lehet helytálló.

C) Számadáskönyvek. A harmadiknak választott 16. századi forráscsoport több szempontból is a két előző közötti átmenetnek tekinthető. A számadáskönyvek ugyanis nem hivatalos, hanem belső használatra készültek: egy-egy család birtokait érintő kiadások és bevételek könyvelésére szolgáltak. Ezért az ezekben feljegyzett névadatok nyilvánvalóan közelebb állnak az élőszóbeli névhasználathoz, mint a hivatalos ügyeket rögzítő oklevelek névadatai.

Az általam választott Kanizsai-számadáskönyv (NÓGRÁDY 2011) 1520-1522 között készült, 3 vár (Sárvár, Kapuvár és Léka), Csepreg mezőváros és a Fertő tó könyvelését tartalmazza. A korábbi két forrástípushoz hasonlóan ez is latin nyelvú. A benne szereplő névadatokat megvizsgálva azt láthatjuk, hogy a nemesek nevében nem fordul elő latin névkiegészítő (pl. Johannem Banfy, NÓGRÁDY 2011: 21; dominus Johannes Kanysay, NÓGRÁDY 2011: 117). Ezzel szemben a jobbágyok névadataiban nemcsak latin kiegészítő nélküli (Stephanus Demeter, NóGRÁDY 2011: 56), hanem egyelemú (Stephano, NÓGRÁDY 2011: 41), körülírásos (Andree carpentario, NÓGRÁDY 2011: 34) és latin kiegészítős is (Johanni Veres de Elbew, NÓGRÁDY 2011: 94) megjelenik.

Ezeket az adatokat a korábban látott két, 16. századi forrástípussal formai szempontból összehasonlítva arra a következtetésre juthatunk, hogy az ugyanazon társadalmi rétegekbe tartozó névviselők személyjelölő szerkezetei eltérnek a különböző típusú forrásokban. Ahogyan már N. FODOR JÁNOS is megállapította a Kállaiak személyjelölő szerkezeteinek vizsgálata kapcsán, a nemesek nevének élőszóbeli, magyar változata ebben az időszakban csak a belső használatra szánt dokumentumokban volt használatos, a hivatalos céllal készült oklevelekben azonban a latinos forma volt használatos (N. FODOR 2010: 54). Az előző (B pontban látott) elemzés alapján levont következtetésünkkel ellentétben tehát, ha formai szempontból értékeljük a számadáskönyv névadatait, arra jutunk, hogy a nemesség körében már kialakultak és általánossá váltak a családnevek, az alsóbb rétegekben azonban még folyamatban van elterjedésük.

Ráadásul a számadáskönyvekben egy újabb kritériumot is találhatunk a családnévség megítéléséhez. Mindkét társadalmi réteg névadatai között előfordul ugyanis, hogy az egyénnév helyett az eddig csak kiegészitő szerepben látott másik névelemmel jelölik meg az adott személyt: ad dominum Sechi (arisztokrata, NÓGRÁDY 2011: 34), Salay (jobbágy, NóGRÁDY 2011: 19). Ez az önmagában álló név már nagy biztonsággal családnévnek tekinthető, de nem formai, hanem funkcionális szempont alapján: önállóan tölti be ugyanis a név legfőbb funkcióját, az azonosítást. 


\subsubsection{Végkövetkeztetések}

A fentieket megfontolva világossá válik, hogy a névadatok szerkezete erősen függ attól, milyen típusú forrásból nyerjük őket (erre l. még SLíz 2012a: 298, TÓTH 2013: 230-232). Ezért az eltérő forrástípusból származó névadatok összevetése csak kellő kritikával végezhetô el. Emellett az is bebizonyosodott, hogy a formai szempontok nem használhatók a családnévség megitélésének kritériumaiként, hiszen a névadatok szerkezete nem feltétlenül a valós névhasználatot tükrözi, hanem sokkal inkább a hivatalos írásbeliség korszakonként és forrástípusonként is eltérő, illetve a névviselő társadalmi helyzetétől is függő névlejegyzési szokásait. A későbbi, 16. századi forrásokból, mint láttuk, nagyobb biztonsággal rekonstruálható az élőnyelvi névhasználat, mint a 14. századiakból, ugyanakkor az is lényeges szempont, hogy a forrás milyen célból készült. Azokból a forrásokból, amelyek belső használatra készültek, mint például a számadáskönyvek, hitelesebb képet kaphatunk a korabeli élő névhasználatról, mint a hivatalos céllal írt oklevelekből. Ez utóbbiak készítése során ugyanis a nevek lejegyzői erősebben ragaszkodtak a hivatalos írásbeliségben évszázadok alatt kialakult normákhoz, melyek általában eltakarják szemünk elől a valós névhasználatot.

\subsection{A megkülönböztető névelemek és az oklevélírási gyakorlat}

\subsubsection{A vizsgálat célja}

Mint az előző fejezetből láthattuk, a rendelkezésünkre álló forrástípusok közül a szorosabb értelemben vett birtok- és jogi ügyekkel kapcsolatos oklevelek a legkevésbé alkalmasak a családnevek kialakulásának vizsgálatára; sajnálatos módon azonban éppen abból az idôszakból, amikor megindult a megkülönböztető névelemek öröklődése, azaz családnévvé válása (14. század), nem nagyon áll rendelkezésünkre más típusú, nagyobb ívű személynévtani vizsgálatra alkalmas forrás. Korábban több írásomban is bemutattam már a 14. század első felének oklevélírási gyakorlatában jelentkező személyjelölő szerkezetek tipikus és kevésbé tipikus felépítését, s azt, hogy e szerkezetekből milyen következtetésekre juthatunk a családnevek kialakulása kapcsán (pl. SLÍZ 2008, 2009, 2012a). A következőkben - a 14. század közepéről, illetve a 15-16. századból származó adatokkal is bővítve korpuszomat azt igyekszem feltárni, hogy az oklevelek személyjelölő szerkezetei - fent jelzett hátrányuk, az élőnyelvi névhasználattól való nagyobb fokú eltérésük ellenére - hogyan használhatók a családnévtörténet e korai szakaszának vizsgálatára. Ennek során két 
nagyobb témára térek ki: egyrészt az élőszóbeli névhasználat megjelenésére a hivatalos írásbeliségben, másrészt a helynévi eredetú megkülönböztető névelemek hivatalos írásbeliségben való használatának és jelölésének néhány jellemzőjére.

\subsubsection{Az élőszóbeli névhasználat jelentkezése a hivatalos írásbeliségben}

A személyjelölő szerkezeteknek a latin oklevélírási gyakorlatban kialakult típusai nem feleltethetôk meg egyértelmúen sem a HOFFMANN ISTVÁN által felállitott személynévelemzési modell (HOFFMANN 2008) kognitív-pragmatikai szempontú rendszerének, sem pedig a megkülönböztető névelemekből kialakult magyar családnevek jelentéstani-motivációs rendszerének (vö. N. FODOR 2008a), hiszen míg azok valós névrendszereket írnak le, addig e kategóriákat formális szempontok alapján, mesterségesen hozták létre, ráadásul egy idegen nyelv grammatikájának megfelelően. Így az oklevelek személyjelölő szerkezeteiben lévő ún. dictus-os nevek ugyan többnyire leíró vagy sajátosságjelölő nevek (pl. Nicolaus dictus Butus, 1348, AO. 5: 183), de a de-vel bevezetett nevek szintén ide sorolandók; a nexusnevek pedig két oklevélbeli típust is képviselnek: egyrészt a filius-ost valamely rokonhoz való tartozás kifejezésére, másrészt a de generé-set a nemzetséghez való tartozás jelzésére. Ami a családnevek jelentéstani-motivációs rendszerét illeti, a dictus számos jelentéstani-motivációs kategóriába besorolható - például a valamely néphez, népcsoporthoz való tartozást, a névviselő külső-belső tulajdonságát, társadalmi helyzetét, foglalkozását kifejező megkülönböztető névelem kapcsolását is ellátta. Mivel e tanulmány célja a személynevek írásban való megjelenítésének vizsgálata abból a szempontból, hogy mikor és hogyan lehet az írásbeli szerkezetekből a szóbeli névhasználatra következtetni, a továbbiakban az oklevélírási gyakorlat fenti négy kategóriáát veszem alapul.

Mint fentebb jeleztem, forrásaink közül a szorosabb értelemben vett birtok- és egyéb jogi ügyekkel foglalkozó oklevelek állnak a legközelebb a hivataloshoz egy, a forrás célját, illetve használati színterét tükröző skálán, melynek két végpontja a hivatalos és a magán. A 14. századi személyjelölő szerkezetekben a hivatalosság a következő jellemzőkben figyelhető meg:

- latin vagy latinosított, esetleg latin esetragokkal ellátott egyénnévváltozatok (pl. Petrus, Adamus, Peteum);

- latinosított megkülönböztető névelemek, magyar toldalékaik helyett latin névkiegészítő elemekkel kapcsolva, ritkábban azok nélkül (pl. [filius] Petri, [de] Agria, ${ }^{26}$ [dictus] Niger);

${ }^{26}$ Megjegyzendő, hogy a helynevek legalább olyan gyakran, sőt inkább gyakrabban szerepelnek e szerkezetekben magyarul, mint latinul. Azt, hogy milyen nyelven bukkannak fel e 
- latin névsorrend (pl. Johannes filius Gyula; 1353, AO. 6: 8);

- a megkülönböztető névelemek kombinálása (pl. Nicolaus dictus Ekus filius Thome de sub castro Budensi; 1350, AO. 5: 408);

- latin kifejezések bekerülése a személyjelölő szerkezetbe (pl. rangot, tiszteletet kifejező jelzők; szövegbeli visszautalást segítő elemek; deiktikus elemek; 1. pl. m a gis ter Ladislaus filius quondam comitis Nicolai filii Danus [1350, AO. 5: 398]; magistrum Nicolaum filium predicti Elley [1351, AO. 5: 486]; Nicolaus filius Egidii de e a de $m$ Sumus [1351, AO. 5: 520]);

- a megkülönböztető névelem helyettesítése visszautaláskor latin névmással (pl. Nicolao filio Petheu ac Petro filio Andrea de e a de m [1351, AO. 5: 522]).

\subsubsection{Az élőszóbeli névhasználat jelentkezése az egyénnevekben}

A fenti, tipikusnak nevezhető gyakorlattól való eltérés a kevésbé hivatalos irányba való elmozdulást jelent. Az egyénnevek terén ez megnyilvánulhat egyrészt a latingörög eredetű nevek valamely magyar változatának az oklevélbe kerülésében, legyen az akár a mai keresztnévvel megegyező alapváltozat: Moric (1351, AO. 5: 431), Margith (1352, AO. 5: 573), Sandur (1352, AO. 5: 616); akár képzéssel, elvonással vagy egyéb módon alakult névváltozat: Kathus (1346, AO. 4: 556), Mykow (1346, AO. 4: 565-566), Gurk (1346, AO. 4: 577) stb. Mint korábban láttuk, a magyar mellett más, nem latin nyelvű változatok is bekerülhettek az oklevélbe: pl. Gan (1323, KárOkl. 53; vallon 'János'), Nykul (1351, AO. 5: 536; német 'Miklós'). Habár ez utóbbiak időnként szintén latinosítva jelentek meg: Gihaninus (1323, AO. 2: 103), Nykelynus (1352, AO. 5: 576). Másrészt mivel a nem latin-görög eredetű neveket is gyakran latinizálták, ezek nem latinosított változatai is az élő névhasználatot jelzik: Kokas (1352, AO. 5: 554, magyar); Bulchu (1344, AO. 4: 441, török); Herreh (1352, AO. 5: 633, német); Wlchk (1353, AO. 6: 2, szláv).

\subsubsection{Az élőszóbeli névhasználat jelentkezése a megkülönböztető névelemekben}

A megkülönböztető névelemeknek az egyénnévhez kapcsolása egy oklevélben, mint tudjuk, még nem jelenti feltétlenül azt, hogy élőszóban is együtt használták őket. Így például egy Ladislaus filius Thyuodori (1353, AO. 6: 7) adatból nem következik, hogy viselője *Tivadarfi (vagy Tivadar fia) Lásæló-ként nevezte meg magát, illetve hogy környezete e néven tartotta őt számon; ugyanakkor nem is zárható ki e lehetőség.

szerkezetekben, nem a személynevek, hanem a helynevek oklevélbeli lejegyzésének számos tényező által befolyásolt korabeli gyakorlata alakítja. (Ehhez vö. 4.4.2.2. fejezet.) 
Amikor az egyénnévhez csak egyetlen megkülönböztető névelem kapcsolódik, többnyire elképzelhető, hogy az egyénnév melletti elem valós használatot tükröz (természetesen hivatalosítva), tehát például a helynévi eredetủ elem valóban használatos volt a személy megjelölésére élószóban is, persze nem latinul, hanem az adott vulgáris nyelven (pl. Petrus de Thur [AO. 5: 134-135] valóban Túri Péter-ként volt ismert a környezetében). Minél több megkülönböztetô névelem kombinálódik azonban az oklevélbeli szerkezetben, annál kevésbé valószínú a szerkezetnek az élő névhasználattal való összekapcsolhatósága.

\subsection{A dictus-szal kapcsolt szerkezetek}

A dictus-szal kapcsolt megkülönböztető névelem kivételnek számít abból a szempontból, hogy e latin kifejezés jelentésénél fogva ('valaminek vagy valamilyennek mondott') köztudottan arra utal, hogy az ezzel bevezetett névelemet ténylegesen használták a mindennapokban az egyén megnevezésére. Az ilyen névelemek gyakran eleve anyanyelven kerültek be az oklevelekbe, de még a jelentős mennyiségú latinra fordított névelem is egyértelmúen jelzi, hogy anyanyelvi eredetijük valóban használatos volt; így ezek is szolgáltatnak bizonyos információt az élő névhasználat vizsgálatára. Igaz, kevesebbet, mint az anyanyelvúek, hiszen nem lehetünk biztosak abban, hogy melyik, Magyarországon használatos nyelvrôl fordították őket, sőt még abban sem, hogy a szinonimasorból melyik szót fordíthatták az adott latin kifejezéssel. Erre figyelmeztetnek N. FODOR JÁNOS következő adatai, melyekben két szinonimát ugyanazzal a latin szóval adtak vissza: 1468 u.: Petrus Sartor = 1468: Petrus zabo (FTSznSz. 265, 208), 1468 u.: Stephanus Sarthor = 1468: Stephanus nüwrew (FTSznSz. 265, 174).

Egyes ritka esetekben a dictus olyan megkülönböztető névelemet vezet be, amelyet tipikusan más latin névkiegészítő elemmel, azaz filius-szal vagy de-vel szokás kapcsolni. Apanévi eredetű megkülönböztető névelemet vezet be például a következő esetben: Mauricius dictus Abraam filius Abrae rufi de Cheklez (1347, AO: 5: 105), sőt talán a következő adatban is: Dominico dicto Mach k a filio Johannis de Zolyo (1349, AO. 5: 337). Itt ugyan arra gondolhatnánk, hogy Domokost valamely tulajdonsága miatt, metaforikus alapon a macskáról nevezték el, a következő adat azonban arra utal, hogy e megkülönböztető névelem az apa egyénneve is lehet: Nicolaus et Dominicus filii Mochk (1344, AO. 4: 469).

Míg a fenti kevert típus szórványosnak nevezhető (legalábbis a 14. század közepéig), addig a dictus-szal kapcsolt helynévi eredetú megkülönböztető névelemek szintén ritkán, de az apanévinél nagyobb számban adatolhatók a 14. század első felének okleveleiből. Ezek magyarosabb változata, a dictus melletti -i képzős helynév (pl. Johannis filii Michaelis dicti Fy zeri [1352, AO. 5: 615]; filii [...] Petri Rudai dicti [1352, AO. 5: 574], Petrum filium Emerici, Chugi dictum [1354, AO. 6: 243], 
Johannem dictum Ewry [1355, AO. 6: 349], relicta [...] Michaelis dicti Dobazy [1356, AO. 6: 452]) csupán néhány alkalommal fordul elő a 14. század közepéig, hiszen maga az -i képzős helynév is ritkának mondható még ekkoriban a személyjelölő szerkezetekben (de-vel valamivel gyakoribb, pl. Beke filius Jacobi de Te nky [1350, AO. 5: 385], mint de nélkül: Dionisius filius Mark $Z$ a a de le $i$ [1345, AO. 4: 508]; stb.).

A latinosabb dictus + de + helynév szerkezettel a 14. század elején még csak mutatóban találkozhatunk, később azonban aránya lassú, bár egyenetlen növekedést mutat (23. táblázat). E szerkezet FEHÉRTÓI KATALIN (1969: 13) szerint olyan átmeneti forma, amely közelebb áll a latinhoz, ezért ő nem is foglalkozott vele vizsgálata során. Véleményem szerint azonban nem a latin szerkezetek véletlen vagy átmeneti keveredéséról van itt szó, hanem arról, hogy a dictus - bár az oklevélírási gyakorlat nyelvi eszközével - az élő névhasználatról tanúskodhat az apaneves és a helyneves szerkezetben is, szemben a tipikus apa- vagy helyneves szerkezetekkel, melyekről nem tudni, volt-e mögöttük valós névhasználat. Ezért az efféle, dictus + apanév/helynév szerkezetek nagyon is értékesek lehetnek a kutatás számára.

\begin{tabular}{|c|c|c|}
\hline Évtized & $\mathbf{d b}$ & $\mathbf{\%}$ \\
\hline $1301-1310$ & 2 & 0,20 \\
\hline $1311-1320$ & 1 & 0,06 \\
\hline $1321-1330$ & 7 & 0,30 \\
\hline $1331-1340$ & 16 & 0,60 \\
\hline $1341-1350$ & 14 & 0,40 \\
\hline $1351-1359$ & 17 & 0,61 \\
\hline
\end{tabular}

23. táblázat: A dictus $+d e+$ helynév szerkezet összes névadathoz viszonyított arányának változása a 14. század első felében

\subsection{A rokon nevéből eredő megkülönböztető névelemek}

E névelemek a 14. századi oklevelekben még tipikusan a filius latin névkiegészítôvel kapcsolódnak az egyénnévhez, kevésbé tipikusan pedig egyéb rokoni viszonyt kifejezô latin szóval. A filius elmaradása a szerkezetből a 14. század első felében még csak kivételesen fordul eló (Nicolaus Uluingii [1347, AO. 5: 152]), és az apanév ilyenkor is többnyire latin birtokos esetben áll. Felbukkan ugyanakkor már szórványosan a magyar birtokjeles/patronimikumképzős forma; pl. Simon fili us B ala se (1347, AO. 5: 87), Cozme filii B ala se (1347, AO. 5: 106). Ennek ritkaságát jól tükrözi, hogy FEHÉRTÓI KATALIN az általa áttekintett oklevelekben nem is talált rá adatot, ezért úgy vélte, csak a 15. században alakulhatott ki (FEHÉRTói 1969: 11). Itt ismét a magyar és a latin szerkezet „keveredésének”, a birtoklás kétnyelvű, redundáns jelölésének lehetünk tanúi. Pontosabban tehát annak, hogy a magyar éló névhasználatot az írnok a latin oklevélírási gyakorlat megszokott eszközeivel próbálta visszaadni írásban. 
Az -é $(-i,-a /-e)$ patronimikumképző mellett az apanév másik magyar kifejezője a -fi utótag/képző. Ennek történetérôl, különösen a későbbi századokra vonatkozólag, már rendelkezünk áttekintéssel (1. FARKAS 2010), a korai időszakról (14-16. század) azonban a kevés és egyenetlen földrajzi és időbeli megoszlású adat miatt egyelőre még nem alakult ki világos képünk. BENKŐ LORÁND (1948-1949/2003: 374) nagyobb korpuszok hiányában még úgy vélte, hogy a $-f i$ szinte kivétel nélkül nemesek nevében fordult elő. KNIEZSA ISTVÁN (1965/2003: 287) osztotta ezt a véleményt, s a jelenséget azzal magyarázta, hogy e képzési forma a 14-15. században volt a legerősebb, a 15. század vége felé és a 16. századra viszont, mikor a jobbágyok családnevei keletkeztek, már kihalófélben volt.

A fenti magyarázatot megkérdőjelezi, hogy FEHÉRTÓI KATALIN (1969) mindössze két ilyen nevet talált a 14. századból (pontosabban egyet, a második ugyanis -fia utótagú), saját 14. századi korpuszomban pedig egy sem bukkant fel. Helynevekben - jellemzően a -fia utótaggal - inkább megtalálhatók a 14. században, habár szintén nem nagy számban: Ernefyastephampaulia (1322, AO. 2: 45), Deseufiastephanloka, Gywrynfiamarkloka (1337, AO. 3: 331) stb. FEHÉRTÓI KATALIN szerint (1998: 463) ezek a személyjelölő szerkezetek eredendően mesterséges alakulatok lehettek, s korábban magam is egyetértettem vele (vö. SLíz 2011b: 204). Csakhogy e nevek annyit kétségtelenül bizonyítanak, hogy a -fi, -fia utótagú megkülönböztetô névelemnek léteznie kellett már a 14. században. Mivel azt kizárhatjuk, hogy az oklevélírási gyakorlat filius-os megkülönböztetô néveleme alakította ki az éló névhasználatot, amelynek létére a következő századokból már számos példát találhatunk, a - fi utótagú megkülönböztető névelemek 14. századi okleveleinkben tapasztalt ritkaságának okát inkább a hivatalosságra jellemző latinizálásban kell látnunk.

Ami a névviselók társadalmi helyzetét illeti, a FEHÉRTÓI-féle neveket jobbágyok viselik, ahogyan 16. századi források, így az 1524-es VeszprUrb. vagy az FTSznSz. adatai is azt tükrözik, hogy a nemtelenek között is számosan viseltek $f i$-s nevet. Az utóbbiban például 21 ilyen név fordul elő 1501-1526 között, s ebből 17 jobbágy.

E nevek területi elterjedéséről szintén keveset tudunk még. HAJDÚ MiHÁLY (2003: 812) szerint e képzésmód a Dunától keletre volt jellemző; ugyanakkor a jórészt dunántúli adatokat tartalmazó VeszprUrb.-ban is jelentős számban fordulnak elő $f i$-s nevek. VÖRÖS FERENCnek az 1720-as országos összeírás alapján a $f i$-s családnevekrôl készített térképe (2017: 526) szintén inkább azt támasztja alá, hogy e névtípus az egész országra kiterjedt, sôt a Dunántúl nagy részén - legalábbis akkoriban - jellemzőbb volt, mint a Dunától keletre. Bár a 18. század elejét illetően nem hagyhatjuk figyelmen kívül a 16-17. századi népességmozgásoknak a területi megoszlást módosító hatását, a névfajta országos elterjedtségére ez önmagában nemigen szolgálhat magyarázattal.

Mindezek alapján, az egész ország területét felölelő, több évszázadra kiterjedő, minden társadalmi réteg adatait tartalmazó, egységes szempontok alapján összeállított korpusz(ok) hiányában egyelőre úgy tűnik, hogy e képzésmód a 14. században 
már biztosan létezett, de az oklevélírási gyakorlat tipikus személyjelölő szerkezetei között a többi magyar nyelvú formához hasonlóan még csak szórványosan, kevésbé tipikusként bukkant fel írásban. Emellett egyelőre úgy tűnik, a képző használata jóval általánosabb és szélesebb körű lehetett a korábban gondoltnál: nem korlátozódott sem egyik vagy másik társadalmi rétegre, sem pedig egy adott vidékre.

\subsection{A helynévi eredetű megkülönböztető névelemek}

A helynévi eredetú megkülönböztető névelemek között, mint láttuk, a 14. század közepéig még ritkán jelentkezett a tipikus latin szerkezettől elütő, az élő névhasználatról tanúskodó forma, bár fokozatosan növekedett az - $i$ képzős helynevek aránya a személyjelölő szerkezetekben. E képző változatára, a -si-re viszonylag kevés adatot ismerünk az ómagyar korból, különösképpen a 15. századból. (A -si képző történetéhez, illetve személynévi adataihoz 1. pl. KÁZMÉR 1967, 1970; VÖRÖs 2011a.) E morfémára további személynévi bizonyítékokat találhatunk a 15-16. századból, ha a latinizált változatokat is figyelemmel kísérjük: 1439: Jacobus de w j̈falws, 1520: condam Sebastiani et Johannis de Ẅ̈falws (FTSznSz. 285). Ezekben az írnok az -i-t ugyan „lefordította” annak szokásszerú latin megfelelőjével, az -s képzőt azonban az élő névhasználatról árulkodó módon a helynév végén hagyta.

\subsubsection{A helynévi eredetü megkülönböztető névelemekkel kapcsolatos egyéb kérdések}

\subsubsection{A helynévi eredetű megkülönböztető névelemek cserélődése az egyénnév mellett}

A 14-15. századi személyjelölő szerkezetekben nem volt ritka, hogy egy több birtokkal is rendelkező nemesre vonatkozó oklevélbeli személyjelölő szerkezetben különböző birtokok nevei fordultak elő. N. FODOR JÁNOS (2004: 43) a Gutkeled nembeli Apaj-alág személyjelölő szerkezeteinek vizsgálata alapján arra a következtetésre jutott, hogy a helynév kiválasztása nem véletlenszerủen történt: mindig annak a birtoknak a neve került be a személyjelölő szerkezetbe, amelyen a névviselő élt; más birtok neve akkor sem szerepelt benne, ha azt érintő ügyben született az oklevél. Más családok névadatai ezt megerôsítik, azzal a megjegyzéssel, hogy alkalmanként talán mégis megjelenhet a személyjelölő szerkezetben annak a birtoknak a neve, amellyel a jogi ügylet kapcsolatos. Így például a Rátót nembeli Pásztói családhoz tartozó Domokos neve ugyanazon 1348-as oklevélben egyszer a Dominicum magnum et Stephanum filium suum de $P a z t u h$, egyszer pedig a Dominicum magnum de Haznus (AO. 5: 221) szerkezetben olvasható. Egy nem sokkal későbbi oklevélben 
ugyanő ismét mint de Haznus jelenik meg (AO. 5: 223), egy 1353-as oklevélben azonban ismét Dominicus magnus de Pątuh filius condam Dominici palatini (AO. 6: 50) szerepel. Az, hogy Domokos egyénneve mellett hol Pásztó, hol Hasznos neve jelenik meg a különböző oklevelekben, nem meglepő, az azonban már szokatlan, hogy a helynévi eredetú megkülönböztető névelemek egy oklevélen belül is cserélődnek. Ennek talán az lehet a magyarázata, hogy a feltételezhetőleg hasznosi birtokán lakó Domokost az adott ügyben pásztói birtokán idézték meg.

A helynév személyjelölô szerkezetbeli cseréje a birtokjog változásával is összefügghet. Arra már többen is említettek példát még a 15. századból is, hogy ha valaki a meglévőnél nagyobb, jelentősebb, ismertebb, illetve az udvarhoz közelebbi birtokot szerzett, a régi helyett az új birtok neve került az egyénneve mellé az oklevélben (1. pl. MiKeSY 1959: 83, SZÉKELY 1970: 205, KuBINYI 2003: 100). A következőkben egy olyan esetet mutatok be, amikor a birtokosztály következtében cserélódnek, illetve különülnek el az egyes alágak személyjelölő szerkezeteiben a helynevek.

A Födémesen lakó Hontpázmány nembeli Födémesi ághoz tartozó Miklós és unokatestvérei, Jákó és Péter 1349-ben közösen léptek fel Hont, Esztergom és Bars megyei birtokaik ügyében (AO. 5: 300). Az ezt megörökítő oklevélben Miklós egyénnevéhez a de Fedemus kapcsolódik, rokonai egyénnevéhez viszont nem csatoltak helynévi eredetű megkülönböztető névelemet, kerülendő a tautológiát, hiszen ôk is födémesiek voltak. Ugyanezen évben, egy osztozkodás során Jákó elismerte, hogy Miklóssal szemben nincsen joga Parasához (AO. 5: 312). Az erről szóló oklevélben Jákó de Fydymes-ként szerepel, hiszen Födémes még közös birtokuk volt; Miklós azonban annak ellenére kapta meg a de Parasa megkülönböztető névelemet, hogy továbbra is Födémes volt a lakhelye. Ennek a célja vélhetôleg az volt, hogy a személyjelölő szerkezettel is jelezzék Miklósnak a birtokhoz való jogát, szemben Jákóval. Ezt a feltételezést erősíti egy másik, 1350-ből származó oklevél, melyben az osztozkodás folytatásaként a rokonok megállapodtak, hogy Miklós kapja Födémest és Parasát, Jákó pedig Szuhát és Szkornát (AO. 5: 364). Ebben Miklós ismét de Fedemus-ként tűnik fel, ami világosan jelzi, hogy a korábbi de Parasa csak alkalomszerú, jogerôsítő célzatú megjelölés lehetett. Jákó ezzel szemben de Zwhay lett, nevével is jelezve, hogy immár nincs joga Födémesre, Szuhára ellenben Miklós nem tarthat igényt.

A fenti két példa arra utal, hogy bár az élőnyelvben a 14. században feltehetőleg már megkezdôdött a helynévi eredetű névelemek állandósulása egy-egy család jelölésére, az oklevelekben a család lakhelyével, valamint különböző jogesetekkel összefüggésben még nem ritkán cserélődtek e névelemek az egyénnév mellett, többek között azért, mert e megkülönböztető névelemnek ha nem is jogbiztosító, de legalábbis a birtokjogot jelölő szerepet is tulajdonítottak. Ezt támasztja alá az az általam korábban (SLíZ 2011b: 205) már említett 1325-ös oklevél is, amelyben az országbíró utasítja a pozsegai káptalant, hogy állapítsa meg, Benedek fia Miklós apját a de Saagh vagy a de Zueyboch névvel illették-e (AO. 2: 176); a kérdés nyilvánvalóan a két említett birtok tulajdonjogát érintette. 


\begin{tabular}{|c|c|c|c|}
\hline Évszám & Miklós & Jákó & Forrás \\
\hline 1349 & $\begin{array}{l}\text { Nicolaus filius Nicolai de } \\
\text { Fe de mus }\end{array}$ & Jaco et Petri filii Stephani & AO. 5: 300 . \\
\hline 1349 & $\begin{array}{l}\text { Nicolaus filius Nicolai de } \\
\text { Paras a }\end{array}$ & $\begin{array}{l}\text { Jakou filius Stephani de } \\
\text { Fydy mes }\end{array}$ & AO. 5: 312 . \\
\hline 1350 & $\begin{array}{l}\text { Nicolaus filius Nicolai filii Jakon } \\
\text { de Fede } m \text { us }\end{array}$ & $\begin{array}{l}\text { Jakou filius Stephani filii Jakou de } \\
Z \text { w b ay }\end{array}$ & AO. 5: 364 . \\
\hline
\end{tabular}

24. táblázat: A Hontpázmány nembeli Födémesi ághoz tartozó Miklóst és Jákót jelölő személyjelölő szerkezetek

\subsubsection{Több helynévi eredetű megkülönböztető névelem az egyénnév mellett}

Néhány esetben az egyénnévhez két helynévi eredetű megkülönböztető névelem is kapcsolódik, pl. Lorandus filius Nicolai dicti Cantor de Ders et de Hudaz (1358, AO. 7: 337). Ezek együttes alkalmazása - szemben a dicti Cantor-ral - nagy valószínúséggel nem élő névhasználatra utal, így mögöttük még nyilván nem feltételezhetünk helynévi eredetû családnevet. A következő példában azonban más a helyzet: magister Benedictus dictus Worew filius Petri de Budrug nobilis de Sancto Laurencio (1350, AO. 5: 418). Ebben a de Budrug-ról nem lehet eldönteni, hogy melyik egyénnévhez kapcsolódik: Bodrogi Benedekről vagy Bodrogi Péterről van-e szó, esetleg mindkettőről. Ez nem ritka a korabeli személyjelölő szerkezetekben; különlegessége a folytatásban rejlik. Amennyiben ugyanis a de Budrug csak az apára vonatkozik, még bizonyára nem családnév, hiszen a másik helynév szerepeltetése nagy valószínűséggel birtokváltozást vagy osztozkodást jelez. Ha azonban a de Budrug-ot Benedekre is értjük, akkor ezt az elemet már nagyobb valószínűséggel tarthatjuk családnévnek, mely már nem feltétlenül utal származási helyre vagy birtokra (szemben a de Sancto Laurencio-val, amely ráadásul nem is az egyénnévhez, hanem a nobilishez kapcsolódik, így biztosan nem családnév).

Kétszáz évvel későbbi okleveleket vizsgálva már gyakrabban találkozunk ehhez hasonló, bár némileg magyarosabb szerkezetekkel: Stephani Ibranj̈ de wä̈a (1523, FTSznSz. 118). Mint látjuk, itt az egyik helynévi eredetű elem már -i képzővel, a másik pedig még de-vel áll. Ebből - mint azt korábban bemutattam - már igen nagy valószínűséggel következtethetünk arra, hogy az Ibranjy a birtokviszonyoktól függetlenül öröklődő családnév, a de waj̈a pedig a valós birtokviszony jelölője lehetett. Ebből visszakövetkeztetve elképzelhetô, hogy az említett 1350-es adatban is hasonlónak lehetünk tanúi, hiszen a 14. századi korpuszban, mint a 3.3. fejezetben látni fogjuk, már több, bizonyíthatóan öröklődő névelemre is van példa. 


\subsubsection{Az adatok elemzésének tanulságai}

A fenti adatok és megfigyelések alapján jól látható, hogy bár a szorosabb értelemben vett birtokjogi ügyletekkel kapcsolatos oklevelek a képzeletbeli hivatalosmagán skálán a hivataloshoz közeli voltuk miatt a legkevésbé alkalmas források az élő névhasználat felderítésére, bizonyos esetekben mégis megôrizték a korabeli szóbeli névhasználat nyomait. Ezek a nem latin vagy latinizált egyénnevek révén kezdettől fogva fellelhetők voltak bennük; a megkülönböztető névelemek között elóbb szintén csak a szavak szintjén, a dictus-szal bevezetett leíró nevek anyanyelvi változataiban jelentkeztek, majd alkalmilag, a latin szerkezetekkel keverten, lassan növekvő arányban fel-feltûntek az anyanyelvi szerkesztésmódok és toldalékmorfémák is. (Ezekről bővebben, kontaktológiai szempontjából l. az 5.4.3.2. fejezetben.) A latin névkiegészítők fokozatosan eltűntek: a 16. század elejére már csak a de maradt meg (vö. az FTSznSz. 16. századi anyagával).

A de-vel bevezetett megkülönböztető névelemek váltakozása a 14. században még családonként, sőt személyenként is eltérô lehetett; okai között említhetjük a lakhelyváltoztatást, egy adott birtokhoz kötődő eseményt, valamint a birtokjogban bekövetkezett változásokat is. A 16. századra a kevésbé hivatalos forrásokból a többi latin névkiegészítőhöz hasonlóan a de is eltűnt, a birtokjoggal kapcsolatos oklevelekben azonban a hivatalosság eszközeként továbbra is fennmaradt, habár gyakrabban már megváltozott funkcióban: a családnév mellett, a valódi birtoklás jelölőjeként.

\subsection{A névelemek öröklődése}

\subsubsection{A latin nyelvü oklevelek tanúsága}

A családnevek kialakulásának ideje szempontjából a 14. századi személyjelölő szerkezetek vizsgálata során létfontosságú annak bizonyítása, hogy az egyénnév melletti névelem öröklődött-e. A korábbi korpusz alapján mindössze öt esetben lehetett teljes biztonsággal megállapítani, további háromban pedig feltételezni az egyénnév mellett álló névelem öröklődő voltát (vö. SLíz 2011b: 186-187). A következőkben felsorolom mindazokat az adatokat, amelyek az új gyüjtés eredményeképpen kerültek be a korpuszba, gyarapítva ezzel a bizonyítottan öröklődő korai névelemek, azaz talán már családnevek meglehetôsen kis elemszámú listáját:: ${ }^{27}$

27 Amennyiben a család nem található meg ENGEL genealógiájában, ENGELhez hasonlóan magam adok neki nevet a tárgyalás megkönnyítése érdekében, a kérdéses névelem alapján 


\section{Aba nb. Széplaki Csirke ág:}

1322: possessiones Thome et Nicolai filiorum S tephani dicti Chyurke (AO. 2: 90)

1352: contra magistrum Nicolaum dictum Chyrke de Zebes (AO. 5: 599)

Pányoki rokonság, Pálóci ág, ruszkai Bátor család:

1332: unacum [...] Jobanne dicto Batur (AO. 2: 603)

1357: Stephanus filius Johannis dictus Batur (AO. 6: 528)

\section{Ákos nb. Bebek-Csetneki ág, pelsőci Bebek család:}

1340: contra Stephanum Georgium Dominicum et Nicolaum filios Dominici dicti Bubek (AO. 4: 53)

1356: magistros Stephanum et Georgium dictos Bebek de Deresk (AO. 6: 491)

\section{Hontpázmány nb. Forgács ág:}

1345: relicta condam Nicolai dicti Forgach cum Nicolao et Andrea dictis Forgach filiis suis (AO. 4: 499)

\section{Olgyai család:}

1345: Paulus dictus Chuna de Tarnuk (AO. 4: 549)

1355: Paulo filio Andree dicti Chuna (AO. 6: 411)

\section{Hontpázmány nb. Födémesi ág, velezdi Kövér család:}

1347: contra Johannem filium Nicolai dicti Kuer de Verez (AO. 5: 37)

1358: Georgius filius Johannis dicti Kueer de Werez. (AO. 7: 356)

\section{Káta nb. Csaholyi ág:}

1348: contra magistrum Johannem magnum de Chabul (AO. 5: 195)

1357: Petrus magnus de Chahal (AO. 6: 624)

\section{Vértes család (?): 28}

1348: Nicolao dicto Vertes; Petro dicto Vertes (AO. 5: 192)

(vö. ENGEL 2003). Az átláthatóság kedvéért az adatokban ritkítással kiemelem az öröklődó névelemet, valamint azoknak a személyeknek az egyénnevét, akiket e névelem jelöl.

${ }^{28}$ A két névviselő ugyanazon oklevélben szerepel, ezért feltételezhető, hogy rokonságban álltak egymással. 


\section{Cudar család:}

1352: Simonis dicti Zudor filii Domini filii Dionisii de Bulch [...] Petro, Stephano, Georgio, Michaeli, Johanni et Emirico similiter Zudor dicti fratribus suis carnalibus (AO. 5: 541)

\section{Bárkalán nb. Sápi ág(?):}

1353: possessionem [...] quondam Nicolai filii Dominici dicti Cynpo (AO. 6: 107-108)

1353: Nicolai dicti Cympo (AO. 6: 143)

\section{Bárkalán nb. Sápi ág(?):}

1353: possessionem [...] Johannis dicti Tegzus (AO. 6: 107-108)

1353: Dionisium generum Georgii dicti Tegzes (AO. 6: 143)

\section{Fehér család(?): ${ }^{29}$}

1353: contra Georgium filium Demetrii dicti Feyr et Michaelem filium Johannis similiter Feyr $\operatorname{dicti}(\mathrm{AO} .6: 139)$

\section{Kántor család:}

1353: Lorandus, Briccius et Johannes dicti Cantores filii Nicolai (AO. 6: 116)

1357: Nicolai filii Stephani dicti Kantor (AO. 6: 549)

1358: Lorandus filius Nicolai dicti Cantor de Ders et de Hudaz (AO. 7: 337)

\section{Nádasd nb. Darabos-ág:}

1353: Emericus et Ladislaus filii Johannis dicti Darabus (AO. 6: 85)

1353: Laurencius filius Stephani dicti Darabus de Nadasd (AO. 6: 105)

\section{Szatmári család:}

1353: unacum Petro et Johanne dictis de Zathmar (AO. 6:132)

\section{Baksa nb. sóvári Sós család:}

1354: Nicolaum, Georgium, Johannem et Ladislaum filios Petri dicti Sows (AO. 6: 196) 1356: Nicolaus dictus Sows filius Petri de Souar [alább: Nicolaus Sous] (AO. 6: 449) 1358: Johannes dictus Sous de Soovar (AO. 7: 115)

${ }^{29} \mathrm{Uaz}$. 


\section{Aba nb. Csobánka ág, Visontai család:}

1355: Johannem filium Petri dicti Panchelus (AO. 6: 369)

1357: Johanne dicti Pancelus de Cheh (AO. 6: 576) [alább uô: Johannes Pancel dictus; AO. 6: 576$]$

\section{Varjú család(?): ${ }^{30}$}

1355: pro parte nobilis domine consortis magistri Benedicti Varyu (de Meger); Gregorio dicto Varyu (AO. 6: 369)

\section{Diósmacskási Kerek család(?): 31}

1357: Nicolaum filium Jobannis dicti Kerek (AO. 6: 605)

1358: Nicolao dicto Kerek (AO. 7: 149)

\section{Székely család(?): ${ }^{2}$}

1357: magistri Petrus et Georgius dicti Zekel castellani [...] de Baluanus (AO. 6: 591)

Mint látható, az újabb gyűjtés négyszer annyi (20) új esetet hozott felszínre, mint amennyi az 1301-1342 közötti korpuszban található. Ugyanakkor meg kell jegyezni, hogy ezek egy részében ENGEL genealógiája szerint (2003), amely gondosan jegyzi a megkülönböztető névelemeket, csak egy, esetleg két generációra való öröklődést tudunk dokumentálni. A késóbbi generációkban nem bukkan fel az adott névelem, és e családok, ha fenn is maradtak a családnevek általánossá válásának koráig, végül más néven vonultak be a történelembe (pl. Csaholyi, Olgyai).

Korábban már bemutattam olyan családokat, amelyek tagjait részben öröklődő, részben pedig azonos kategóriába tartozó más névelemekkel jelölték meg a kortársak (Vas család, Gyáli család; vö. SLíz 2011b: 189-190). Az újabb gyűjtés egy további hasonló esetre is ráirányította a figyelmemet. A Koppán nembeli Pozsár családban a Pozsár 'ponty' névelem három nemzedék négy tagjánál dokumentálható, de megjelenik a családban egyszer a Harcsa, kétszer pedig a Korc is, míg a család többi tagja esetében nincs nyoma semmilyen közszói eredetű névelemnek (vö. ENGEL 2003). A Korc értelmezése egyébként bizonytalan, mivel a HALAK kategóriához leginkább közel álló, halfogó eszközzel kapcsolatos jelentésre ('nád-, vesszőkerítés fonatos keresztkötése') a TESz. csak 1756-ból hoz adatot. Ugyanakkor a név olvasata Korcs, azaz 'különböző fajtájú egyedektől származó állat, növény' is lehet

${ }^{30} \mathrm{Uaz}$.

${ }^{31} \mathrm{Uaz}$.

${ }^{32} \mathrm{Uaz}$. 
(1358: Korch, AO. 7: 260); habár az első közszói adat a TESz.-ben erre is csupán 1693-ból származik.

Erre a korszakra azonban még sokkal jellemzőbb az, hogy egy személy többszöri említésekor az egyénnév mellett különböző típusú névelemek, ső́t a helynévi eredetû megkülönböztető névelemek között más-más helynevek jelennek meg a forrásokban. A nagyszámú példa közül a legkülönlegesebbnek a Balogsemjén nembeli semjéni Kállaiak személyjelölő szerkezetei bizonyultak: Lengyel János egyénneve mellett legalább három, az István fia Istvánt jelölő személyjelölő szerkezetekben pedig négy birtoknév is előfordul:

\section{Lengyel János:}

1353: in persona Lenkus filii Johannis dicti Lengel de Semien (AO. 6:15)

1357: Ladislaum et Lenkus filios Johannis dicti Lengel de Napkor (AO. 6: 612)

1358: Ladislaum, Lenkus et Abraam filios Johannis dicti Lengel de Kallo (AO. 7: 408)

\section{István fia István:}

1353: Stephanus filius Stephani de Nyr (AO. 6: 82)

1353: Stephanus filius Stephani de Kallo (AO. 6: 91)

1353: magister Stephanus filius Stephani de Nogsemien (AO. 6: 115)

1355: magister Stephanus filius Stephani nob. de Bodolou (AO. 6: 361)

A megkülönböztető névelemek efféle váltogatása, variálása, valamint - mint azt fentebb láttuk - egy személyjelölő szerkezetben több helynév alkalmazása (pl. 1358: Jacobus filius Johannis filii eiusdem Petheuch de Syroka et de Frychk, AO. 7: 523) még egyértelmúen a családnév hiányára utal. Ráadásul a fent említett István fia István egyszer Nyri-ként is megjelenik (1354: magistrum Stephanum filium Stephani Nyri dictum, AO. 6: 187), ami azt jelzi, hogy óvatosan kell bánnunk a latin szövegbe bekerülő magyar toldalékos alakokkal: bár az élő névhasználatot tükrözik, ez lehet alkalmi megjelölés is, és nem feltétlenül jelenti azt, hogy már családnévvel van dolgunk.

Az eddigi tapasztalatokat összegezve tehát úgy tűnik, hogy a 14. század első felében már egészen biztosan megkezdődött a megkülönböztető névelemek öröklődővé válása, e korszakkal kapcsolatban azonban még korai lenne családnévrendszerről beszélni. Az öröklődés gyakran csak egy-két nemzedékre terjedt ki, és egy-egy generációnak sem minden tagja viselte bizonyíthatóan ugyanazon névelemet (sőt több esetben biztosan nem ugyanazt viselték).

\subsubsection{A német nyelvü oklevelek tanúsága}

A latin nyelvű oklevelek mellett ugyanakkor érdemes megvizsgálni a német nyelvúekben megjelenő személyjelölő szerkezeteket is. A magyar névkutatás eddig szinte 
kizárólag az előbbiekre koncentrált (kivéve MOLLAY KÁROLY középkori soproni német családnevekről írt munkáját [1936]), és a latin személyjelölő szerkezetek alapján vont le következtetéseket a családnevek kialakulásának koráról. Ez persze érthető, hiszen középkori okleveleinknek csupán töredékét teszik ki a vulgáris nyelvűek, és ezek is csupán a 14. századtól, nagyobb számban annak is inkább a végétôl állnak rendelkezésünkre.

A latin nyelvű oklevelek személyjelölő szerkezeteinek vizsgálata során a szakirodalom óhatatlanul is erősen támaszkodott a latin nyelv sajátosságaiból adódó formai szempontokra. Ez nem okoz problémát, amennyiben folyamatosan szem előtt tartjuk a korábban már elemzett szempontokat, vagyis az oklevélírásból adódó formai sajátosságokat, továbbá a forrástípusok eltérésének a személyjelölő szerkezetre gyakorolt hatását, és nem próbálunk meg kizárólag a formai szempontok alapján következtetni a megkülönböztető névelemek örökletes voltára. Az afféle változások például, mint a filius, dictus stb. fokozatos eltűnése a személyjelölő szerkezetből, elsősorban az oklevélírás személyjelölő szokásainak a változását tükrözik, nem pedig a megkülönböztető névelemek öröklődôvé válását. Annyiban ugyanakkor e latin elemek eltűnése mégiscsak összefügghet a családnévrendszer kialakulásával, hogy ez az oklevélírásban bekövetkező lassú változás - legalábbis véleményem szerint nem lehet független a családnevek kialakulásától. Úgy vélem, eltűnésük oka a családnevek rendszerének lassú kiépülése, azaz annak érzékelése, hogy ezen névelemek többsége már más típust képvisel, mint a korábbiak (vagyis már nem sajátosságjelölő, hanem nexusnevekről van szó). Mint korábban láthattuk, a latin kiegészítő elemek a hivatalosabb célra készült forrásokban maradtak fenn legtovább, ennélfogva az ezekben szereplő személyjelölő szerkezetek álltak a legtávolabb az élő névhasználattól.

A formai szempontoktól való önkéntelen befolyásoltság esélyét csökkenti, ha nemcsak a latin, hanem más, például német nyelvú oklevelek személyjelölő szerkezeteit is megvizsgáljuk. A magyarországi német nyelvű oklevelek első darabjai a 14. század első felében születtek. A német nyelvú írásbeliség Magyarországon Pozsonyban és Sopronban, valamint a ciszterciek borsmonostori apátságában kezdődhetett. A soproni városi írnokok MOLLAY megállapítása szerint a bécsi egyetemen végeztek, és többnyire osztrák vagy bajor területről érkeztek (1982: 120-121), így a német nyelvú írásbeliség német mintára alakulhatott ki hazánkban.

A németben a családneveknek a magyarhoz (és általában az európai nyelvekhez) hasonló motivációs-jelentéstani rendszere épült ki (vö. pl. SEIBICKE 1982, KOHLHEIMKOHLHEIM 2005: 11-60). E hasonlóságnak köszönhetően a német és latin nyelvű oklevelekben szereplő személyjelölő szerkezetek összevetése nem okoz különösebb problémát. A következőkben a forrásként használt, Sopron szabad királyi város története (SoprT.) címú, tizenhárom kötetes kiadvány 14-15. századi forrásaiban előforduló személyjelölő szerkezetek alapján mutatom be a korabeli magyarországi német oklevélírás személyjelölésére jellemző sajátosságokat. Míg később, a fordítási stratégiák és a névkontaktusok szempontjából végzett vizsgálat során módszertani 
okokból igyekszem majd különbséget tenni a feltehetőleg magyar és nem magyar etnikumú személyek névanyaga között (4-5. fejezet), addig jelen esetben e két kategóriát egységesen kezelem. Abból a szempontból ugyanis, hogy a korabeli német oklevelek milyen nyelvi eszközöket alkalmaztak a személyek megjelölésére, lényegtelen e személyek etnikai hovatartozása, illetve nevük nyelvi eredete.

Az apanévi eredetú megkülönböztető névelemek, illetve családnevek többsége puszta apanévként kapcsolódik az egyénnévhez, pl. Conrad Ernst (1421, SoprT. I/2: 201), Michell Charll (1429, SoprT. I/2: 384), de képzett alakra is találunk példát: Kasbar Adamër (1426, SoprT. I/2: 299). Szórványosan szintaktikai szerkesztés is előfordul: Philipp, Galazz sun 'Philipp, Galazz fia' (1420, SoprT. I/2: 185); ugyane személy neve késóbb viszont már Galas Philipp alakban fordul elő (1420, SoprT. I/2: 186). Elvétve körülírásokkal is találkozhatunk: Stephan, Niklas seligen des Pugkls stiefsun 'Stephan, a megboldogult Niklas Puckl mostohafia' (1421, SoprT. I/2: 198).

A helynévi eredetűek jellemzően kétféleképpen kerültek be az oklevelekbe: 1. a helynévből képzett jelzőként, pl. Peter Öfner 'Budai' (1389, SoprT. I/1: 225), Jorig Eczestarffer 'Enzersdorfi' (1423, SoprT. I/2: 250), Hanns Nürenbergër 'Nürnbergi' (1428, SoprT. I/2: 372); 2. a helynevet prepozícióval kapcsolva, pl. Peter von Ofen 'Budai' (1379, SoprT. I/1: 180), Taman von Schaddendorff 'Schadendorfi' (1431, SoprT. I/3: 31), Jorig zw Pösing 'Bazini' (1435, SoprT. I/3: 108). A lakóhelyre utaló nevekre is akad példa a korpuszban: Steffan am Ekk' 'a saroknál, tkp. Sarki' (1408, SoprT. II/1: 150), Niklas an dem Ortt 'tkp. Helyi' (1427, SoprT. I/2: 329), Peter von $\operatorname{der} A w$ 'tkp. Folyóparti' (1429, SoprT. I/2: 418). (Vö. KOHLHEIM-KOHLHEIM 2005: 33-38, ill. a Vonderau szócikkben.)

A többi motivációs kategóriába tartozó megkülönböztető névelemek, illetve családnevek is közvetlenül, mindenféle kapcsolóelem nélkül csatlakoznak az egyénnévhez; pl. foglalkozásnév: Stephel S neider 'Szabó' (1426, SoprT. I/2: 299), népnév: Jacob Vngerlein 'Magyar' (1435, SoprT. I/3: 159), tulajdonságra utaló név: Swarcz. Hannsen 'Fekete' (1450, SoprT. I/3: 296), tulajdonságra metaforikusan utaló: Niklas Eysvogel 'Jégmadár' (1426, SoprT. I/2: 299).

Mindegyik típus kapcsolódhatott ezenkívül der-rel (illetve függő esetben annak ragozott alakjával) is; pl. Cönrad der Ernst (1425, SoprT. I/2: 272), Matbjis den Schadendorf (1410, SoprT. I/2: 29), Janüs der Smukchenpfenning (1379, SoprT. I/1: 180).

Ha ezeket összehasonlítjuk a latin személyjelölő szerkezetekkel, egyértelmúen kirajzolódik, hogy a német oklevelekben alkalmazott megoldások a latinnál jobban tükrözik az élő névhasználatot. Így például a latin oklevelekkel ellentétben igen ritkán fordul elő bennük egyszerre több megkülönböztető névelem használata; pl. Michel, Mertt Webers sun von Ükëtsch 'Michel, Mertt Weber fia Malomházáról' (1424, SoprT. I/2: 264). Ha tehát pusztán a német okleveleket használnánk fel forrásként, és hagynánk magunkat befolyásoltatni a formai szempontoktól, akkor már a 14. századra a maga teljességében kialakult családnévrendszerrôl beszélhetnénk. 
Hogy ezt a hibát elkerüljük, egyrészt a két nyelv személyjelölő szerkezeteit együttesen kell vizsgálnunk, másrészt a formai szempontok mellett az azonos nyelvú adatok összevetéséből adódó következtetéseket is figyelembe kell vennünk (ezek nélkül az öröklődés ugyanis nem mutatható ki). Ráadásul ezen a ponton már ismét szét kell választanunk a nagy valószínűséggel magyar, illetve német etnikumú személyek névadatait. A németek esetében ugyanis, mint az a fenti példák némelyikéből is látszik, ugyanazt a névelemet többféleképpen is feljegyezhették, arra azonban a feltehetőleg német névviselők névanyagában nem találunk példát, hogy ugyanazt a személyt egyszer például apanévi, másszor helynévi eredetủ névelemmel jelölnék meg. Emellett arra se igen lehet felfigyelni, hogy ugyanazon személy német oklevélben szereplő megkülönböztetô néveleme, illetve családneve egy latin oklevélből kimaradna: a latin nyelvű oklevélbe ezek többnyire dictus-szal vagy latin kiegészítő elem nélkül kerültek be (sokszor a helynévi eredetúek is), pl. Jobanne dicto Smukkonfennengh (1389, SoprT. I/1: 223), Thoma Turenhofer (1399, SoprT. I/1: 262); vagy pedig a motivációs típusuknak megfelelő latin kiegészítő elemmel: Nicolaus filius Matbie de Sadendorff (1430, SoprT. I/3: 6). Ráadásul számos családnévnek több viselőjét is ismerjük Sopronból (pl. Mathjis den Schadendorf és fia, Taman von Schaddendorff), vagyis ezek öröklődése már biztosra vehető. Igaz, arra is akad még példa, hogy két testvér eltérő megkülönböztető névelemet visel: Jorgen Nekchlein testvére Michel der Fül (1420, SoprT. I/2: 183).

Ezzel szemben ugyanebből a korszakból, tehát a 14. század végéről, 15. század első feléből még a magyar arisztokrácia körében is találunk arra példát, hogy mind a német, mind a latin oklevelekben két különböző motivációs típusba tartozó névelemmel jelölték meg a név viselójét; például Berzeviczi Péter tárnokmester esetében apanévi eredetű megkülönböztetô névelemmel: Petri filii Herrici (1419, SoprT. I/2: 167, lat. okl.) és Petri Herrici (1419, SoprT. I/2: 170, lat. okl.), Herlich Peter 'Henrik fia Péter' (1420, SoprT. I/2: 176, ném. okl.); helynévi eredetű megkülönböztető névelemmel: Petrum de Berzevicze (1425, SoprT. I/2: 285, lat. okl.), Petreins von Briswitz. (1429, SoprT. I/2: 416, ném. okl.). Ráadásul latin nyelvű oklevelekben akár mindkét névelem is szerepelhetett: Petrum filium Herreh de Brezeviche (1420, SoprT. I/2: 180, lat. okl.), Petrus Herrici de Berzawycza (1425, SoprT. I/2: 286, lat. okl.). Sőt két arisztokrata család esetében semmiféle megkülönböztető névelem vagy családnév nem jelenik meg a német oklevélben, csak a társadalmi helyzetre utaló körülírás - minden egyes említéskor, következetesen alkalmazva: Graf Wilhalm, graue ze dem Varicbtenstain (Fraknói Vilmos; 1421, SoprT. I/2: 192); Ich graue Stephan vnd ich graue Hanns grauen zum Harrenstein (Kanizsai István és János; 1423, SoprT. I/2: 250). Az említett következetesség miatt felmerül az a lehetőség, hogy ez egyszerủen az arisztokraták megjelölésének módja a német oklevelekben, csakhogy számos más báró (pl. a Garaiak, Rozgonyiak) neve egyszer sem körülírással, hanem vagy a magyar -i képzős alak átvitelével, vagy németre fordítva (von Gara, von Ro̊gon) szerepel. (A magyar nevek fordítására bővebben is kitérek majd a 4. fejezetben.) 
Mindez arra utal, hogy a családnevek használatát a 15. század első felében még a magyar arisztokrácia körében sem tekinthetjük általánosan elterjedtnek, illetve megszilárdultnak. Ezzel szemben úgy tünik, hogy a Német-római Birodalomhoz hasonlóan a magyarországi német lakosságban, de legalábbis a nyugat-magyarországi városok polgárai körében a 14. század végére, a 15. század elejére a magyarnál valamivel előrehaladottabb lehetett a családnevek rendszerének kialakulása, habár teljesnek még korántsem nevezhető. Ez nem is meglepő, ha figyelembe vesszük, hogy a korabeli Magyarország német többségű városai - amint az a soproni oklevelekből is világosan kitűnik - állandó kapcsolatban álltak a német nyelvterület más városaival, polgáraik között rokoni kapcsolatok szövődtek, és a kétirányú mobilitásnak (Magyarországra és Magyarországról) is számos jelét tapasztalhatjuk.

\subsection{Az egyes szerkezettípusok gyakoriságának időbeli változása}

A következőkben a dictus-os, filius-os és de-s személyjelölő szerkezetek gyakoriságának időbeli változását vizsgálva tekintem át egyrészt a személynevek szövegbe illesztésének gyakorlatát, illetve annak változását, másrészt a családnevek kialakulásának e szerkezetek révén is nyomon követhető folyamatát (11. ábra). ${ }^{33}$

Ami a dictus-os szerkezeteket illeti, TÓTH VALÉRIA az ÁSznt. és a jelen elemzés előzményét képező, 1301-1342 közötti adatbázis alapján kimutatta, hogy ennek a 13. század második felében megjelenő típusnak az összes személyjelölő szerkezethez viszonyított aránya a 14. században növekvő tendenciát mutat (vö. TÓTH 2014a: 479). A 14. századi adatokat az újabb gyűjtés anyagával kiegészítve a 14. század második harmadáig megrajzolt görbe jól mutatja e személyjelölő szerkezettípusnak az 1330-as évekig mérsékeltebben, onnantól kezdve viszont erőteljesebben növekvő gyakoriságát az oklevelekben.

A dictus-os szerkezetek előfordulási gyakoriságát a de-s és filius-os szerkezetekkel összevetve jól látható, hogy összességében mindegyiknek az aránya növekszik a 13. század végétől fogva, hiszen ez az időszak a családnevek kialakulásának első szakasza, vagyis a megkülönböztetô névelemek oklevelekben való megjelenésének és írásbeli használatuk kiteljesedésének az időszaka. E szerkezetek gyakoriságának növekedésével ellentétben az egyelemű nevek arányában folyamatos csökkentést tapasztalunk.

33 A de generé-s szerkezetekkel itt sem foglalkozom, mivel ezek oklevelekben való megjelenése megelőzi a többi szerkezetet, írásbeli használatuk gyakorisága egészen más képet mutat, a 14. század közepén pedig már csak ritkán fordulnak elő: 1343-1359 közötti korpuszomban már mindössze 26 adat van rájuk. (A nemzetségnevekről átfogóan l. TÓTH 2014b.) 


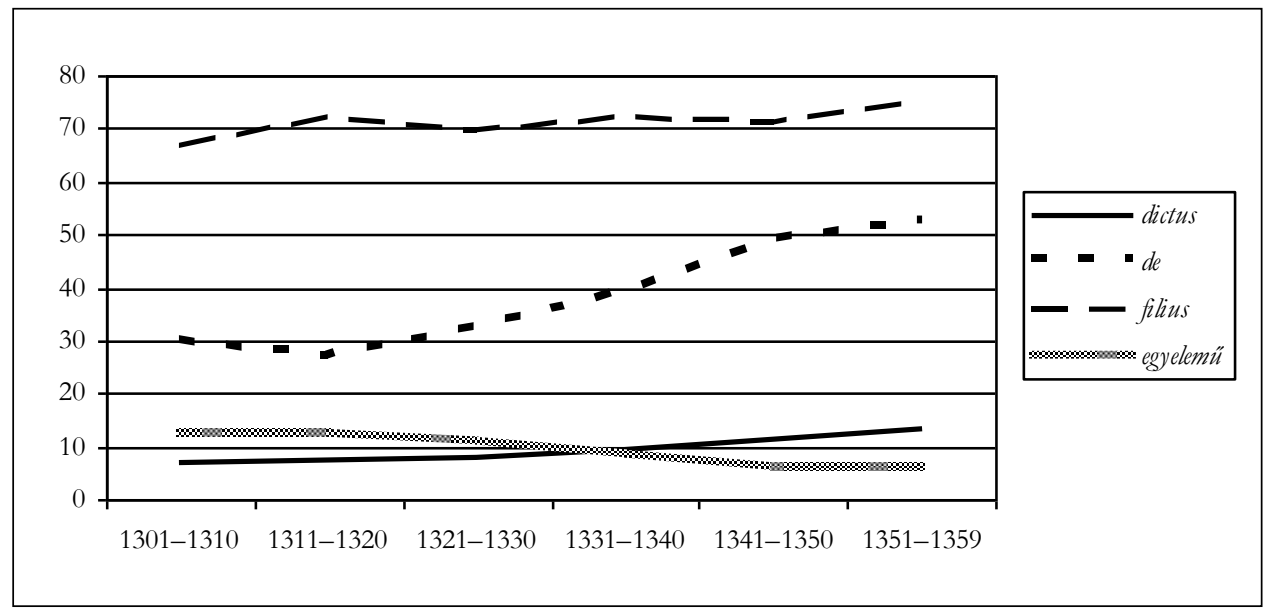

11. ábra: A dictus-os, de-s és filius-os szerkezet, valamint az egyelemű nevek gyakorisága a korpuszban ${ }^{34}$

Az egyes szerkezetek gyakorisága között ugyanakkor jelentős különbségek rajzolódnak ki. A legsikeresebb ebben a korszakban kétségtelenül a filius-os szerkezet, vagyis az apával való kapcsolat jelölése volt, ugyanakkor arányának gyarapodása mérsékelt és hullámzó volt. ${ }^{35}$ A másik két szerkezet sokkal ritkábban fordult elő; a de-s gyakorisága viszont az 1310-es évektől meredeken emelkedve a 14. század közepére egyre jobban megközelítette a filius-os nevekét.

A dictus-os szerkezeteknek a másik kettőhöz képest alacsony (az 1330-as évekig az egyelemú nevekénél is alacsonyabb) gyakorisága mögött véleményem szerint két ok húzódhat meg: az egyik az oklevélírási gyakorlatban, a másik pedig a korpusz összetételében keresendô. Ami az elsőt illeti, úgy vélem, a filius-os és a de-s szerkezet gyakoribb volta abból következik, hogy bár ezek mögött is állhatott viszonylag vagy teljesen állandó élő névhasználat (természetesen magyar, illetve más vulgáris nyelven), jó részük inkább a személynevek alkalmi szövegbe illesztésére vonatkozó, a 13. század második felében kialakuló, majd egyre bevettebbé váló eljárásmódnak

34 Minden olyan szerkezetet figyelembe vettem, amelyben az adott latin névkiegészítő elem szerepelt, tehát a több megkülönböztető névelemet tartalmazó, például egyénnév + filius apanévvel + de helynévvel típusú személyjelölő szerkezetek a filius-os és a de-s állományba is bekerültek.

35 A más személlyel való kapcsolatot jelölő szerkezeteket (pl. frater, nepos) ez esetben nem számoltam, hogy a lehető legtisztábban kitűnjön a filius-os szerkezet gyakorisága. Ezekből a szerkezetekből egyébként igen kevés szerepel a korpuszban, így nem változtatnának szignifikáns mértékben az arányokon. 
köszönhető. Ezzel szemben a dictus mögött - jelentésénél fogva - mindig valós névhasználat állt, s eseteinek számát a másik kettővel ellentétben nem növelhette a scriptorok mesterséges szerkezetalkotása. A másik, a korpusz összetételével kapcsolatos okra a szerkezet társadalmi megoszlásának vizsgálata világíthat majd rá.

Mint a 3.1.2. fejezetben bemutattam, a megkülönböztető névelemeket többféle kombinációban, igen sokféle szerkezetben kapcsolhatták az egyénnevekhez. Ezért azt is érdemes megvizsgálnunk, hogy miképpen változik az egyszerúbb és a bonyolultabb szerkezetek aránya időben, hiszen ezek is lényeges információkkal egészíthetik ki a személynevek oklevélbe illesztésének korabeli gyakorlatáról alkotott képünket.

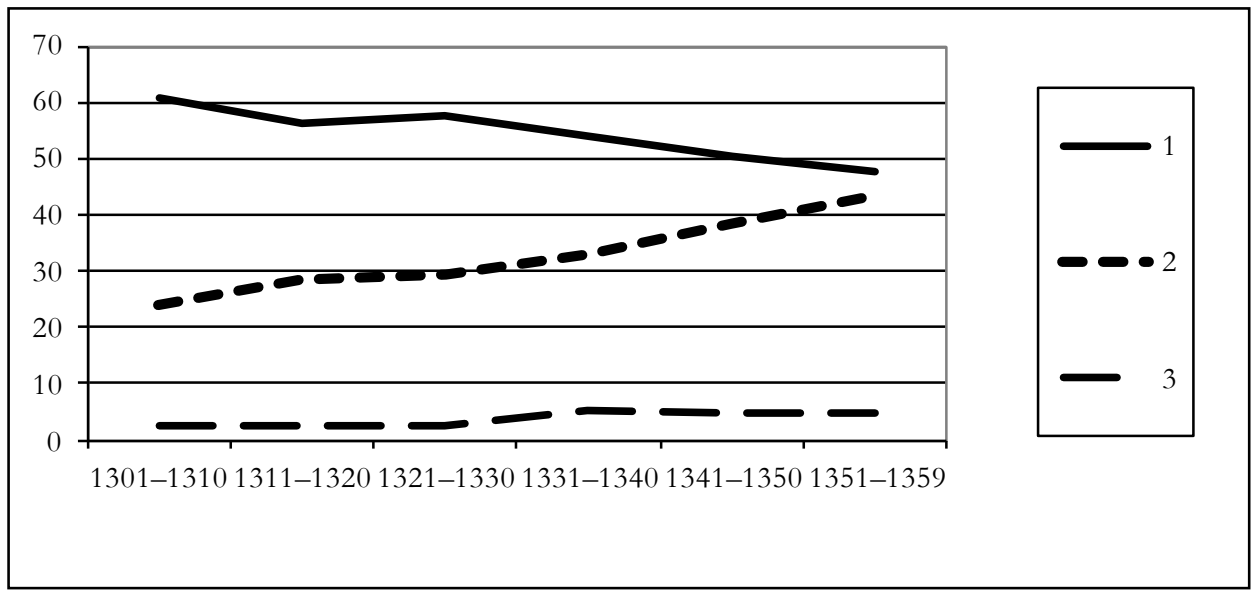

12. ábra: Az egyénnév + 1, 2 és 3 megkülönböztető névelemből álló szerkezetek gyakoriságának időbeli változása

A 12. ábra alapján megállapítható, hogy a leggyakoribb szerkezet a teljes korszakban az egyénnév + egyetlen megkülönböztetô névelem volt, ugyanakkor ennek gyakorisága a bonyolultabb, különösen a két névelemet tartalmazó szerkezetek arányának növekedésével fokozatosan csökkent. Négy és több megkülönböztető névelemet tartalmazó szerkezetek szintén előfordultak, ezek arányát azonban kis számuk miatt nem lett volna értelme kiszámolni (összesen 20 db a teljes, 1301-1359 közötti időszakot átfogó korpuszban).

Mindebből arra következtethetünk, hogy a latin nyelvü oklevélírási gyakorlat a bonyolultabb szerkezetek felé mozdult el, egyre jobban eltávolítva ezáltal a szorosabb értelemben vett birtokügyekkel kapcsolatos oklevélbeli személyjelölő szerkezeteket a valós névhasználattól, egyben pedig feltehetőleg az egyéb, az élő névhasználathoz közelebb álló forrásoktól is (pl. összeírás). 


\subsection{Az egyes szerkezettípusok társadalmi megoszlása}

A 13. ábra az egyes szerkezettípusok fentebb látott gyakoriságának társadalmi hátterét világítja meg. Eszerint a filius-os szerkezet, ahogyan az rendkívüli gyakorisága alapján kikövetkeztethető volt, szinte minden rétegben a leggyakoribb típus, a jobbágyoknál is épphogy visszaszorult a második helyre. A legjellemzőbb a birtokos rétegnél, ami nem is meglepő, hiszen a leszármazás számon tartása, jogi dokumentumokban való jelzése öröklött jogaik és birtokaik megtartása érdekében létfontosságú volt számukra.

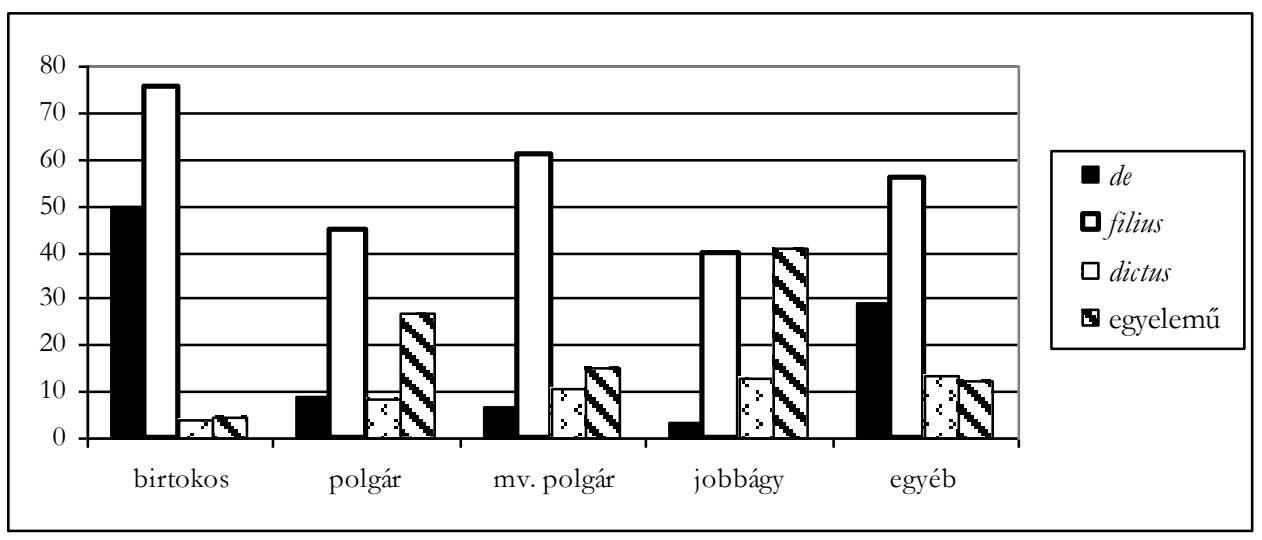

13. ábra: A filius-os, de-s és dictus-os szerkezet, valamint az egyelemű nevek társadalmi megoszlása a korpuszban

A de-s szerkezet a filius általánosabban alkalmazott voltával ellentétben kifejezetten a birtokos rétegbeli gyakoriságának köszönheti fentebb látott megterheltségét. Ez az a szerkezet tehát (nem pedig a minden réteg személyjelölő szerkezeteiben alkalmazott filius-os), amely a birtokosok nevének lejegyzett változatára jellemző a leginkább.

Ugyanakkor nem szabad megfeledkeznünk az adott típusú oklevelek mint források jellemzőiről sem. Az eredményeink ugyanis nem feltétlenül azt mutatják, hogy a de-s szerkezetek a jobbágyok körében a legritkábbak; igen valószínú, hogy egy kizárólag jobbágyok nevét megőrző összeírás egészen más képet mutatna. Erre utalnak legalábbis a későbbi századokból származó összeírások, amelyekben nagy számban találhatók helynévi eredetû családnevek a jobbágyság köréből is. E rétegben a filius-os és de-s szerkezeteknek a többi társadalmi osztályhoz képest szerényebb mértéke, valamint az egyelemú nevek relatív többsége sokkal inkább azzal lehet összefüggésben, hogy míg egy nemes esetében (különösképpen egy birtokkal kapcsolatos ügyben) 
nagy fontossága volt a birtoknévnek, addig egy jobbágy esetében elegendô megkülönböztető erővel bírt pusztán az egyénneve is. A vizsgált oklevelekben egyszerre ugyanis általában legfeljebb 2-3 jobbágy neve fordult elő, így nem volt szükség az egyénnév mellett más megkülönböztető eszközre. Ezzel szemben az összeírásokban szinte kizárólag jobbágyok szerepeltek, ráadásul sok volt közöttük az azonos egyénnevű, ezért e forrásokban logikus módon törekedtek a megkülönböztetô névelemek vagy családnevek pontos feljegyzésére.

Ebből egyben az is következik, hogy a 13. ábrán kirajzolódó kép nem feltétlenül a családnevek kialakulásának társadalmi és időbeli ütemét tükrözi, azaz nem szükségszerūen jelenti azt, hogy a jobbágyság körében később alakultak ki a családnevek, mint a nemességben. Ha ugyanis valóban lett volna jelentős különbség a két réteg között e tekintetben, akkor a dictus-os szerkezeteknek is a jobbágyságban kellene a legalacsonyabb arányban jelen lenniük. Ennek azonban éppen az ellentétét tapasztalhatjuk: az említett szerkezet éppen a jobbágyságra jellemző leginkább. Ennek a jelenségnek az okára a dictus-szal kapcsolt közszói eredetű megkülönböztető névelemek alaposabb elemzése deríthet majd fényt.

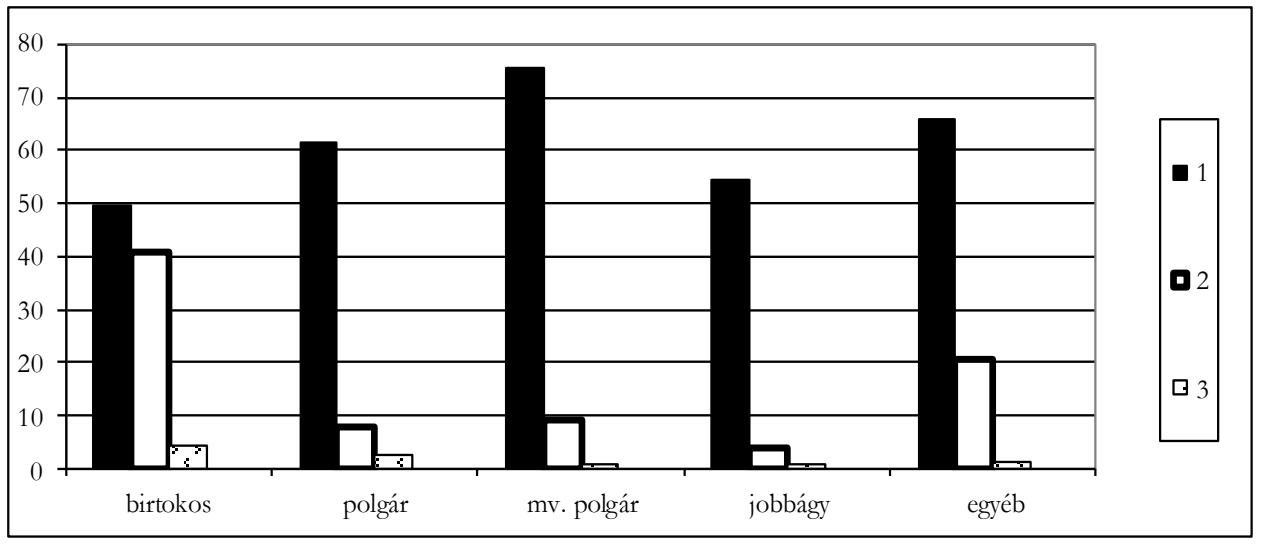

14. ábra: Az egyénnév + 1, 2 és 3 megkülönböztető névelemből álló szerkezetek társadalmi megoszlása a korpuszban ${ }^{36}$

Érdemes továbbá megfigyelnünk az „egyéb”, azaz a társadalmi hovatartozásukat tekintve nem besorolható személyek csoportját. Az itt tapasztalható mintázat leginkább a birtokosokéhoz hasonlít, ahogyan az a leggyakoribb egyénnevek sorrendje

$36 \mathrm{Az}$ egyes rétegeken belüli adatok az ábrán fel nem tüntetett egyelemú nevekkel és a négy vagy több megkülönböztető névelemet tartalmazó szerkezetekkel együtt tesznek ki $100 \%$-ot. 
kapcsán is látható volt. Ennek az lehet az oka, hogy számos officialis, familiaris és famulus található közöttük, vagyis az ide sorolt személyek jó része a birtokosok legalsó rétegébe tartozhatott, vagy közöttük élve igyekezett az előkelőbbek körében érzékelt mintákat követni.

Az előző pontban azt is láthattuk, hogyan változott a megkülönböztető névelemek különféle kombinációiból létrehozott szerkezetek gyakorisága a vizsgált hat évtizedben. A következőkben e szerkezetek társadalmi megoszlására térek ki röviden. A 14. ábra alapján megállapítható, hogy a bonyolultabb szerkezetek leginkább a birtokos réteg személyneveinek a szövegbe illesztésére voltak használatosak a korban. Az egyetlen megkülönböztetô névelem alkalmazása a társadalmi ranglétrán lefelé haladva egyre jellemzőbb volt. Ennek ellentmondó kép csak a jobbágyok esetében tapasztalható; figyelembe kell azonban vennünk, hogy e réteg korpuszbeli névanyagának több mint 40\%-a egyelemú volt.

\subsection{A név oklevélbeli helyzetének hatása a személyjelölő szerkezet felépítésére}

Az egyénnévhez kapcsolt megkülönböztető névelemek száma természetesen nemcsak a névviselő társadalmi helyzetétől vagy az oklevél keletkezési idejétől függött, hanem számos egyéb tényező is befolyásolhatta aktuálisan: így a névviselőnek az adott ügyben betöltött szerepe, magának az ügynek a fajtája, a személyjelölő szerkezetnek a szövegbeli helyzete stb. Mivel ezekről korábbi munkámban már részletesen szóltam (SLÍZ 2011b: 208-228), most csupán egyetlen, különleges esetre hívom fel a figyelmet.

Mint korábban kifejtettem, a személyjelölő szerkezetek általában a személy első említésekor a legbonyolultabbak, azaz ekkor állnak a legtöbb elemből, hiszen új elemként vezetődnek be a szövegvilágba (vö. SLíz 2011b: 225). A későbbi említésekkor, azaz a visszautaláskor viszont már elég akár csak az egyénnév, illetve több azonos egyénnevú lehetséges antecedens esetében az egyénnév és egy megkülönböztető névelem. A visszautalást gyakran anaforikus szerepű latin névmás vagy participium is erősíti, pl. cum predicto Thoma de Rayk 'a korábban említett Rajki Tamás' (1358, AO. 7: 327). Az itt kiemelt példa azért különleges, mert olyan eshetőségre hívja fel a figyelmet, amely az általam áttanulmányozott, hét kötetnyi latin nyelvű oklevélből mindössze egyszer fordult elő. A predictus ugyanis nem az adott oklevélbeli korábbi említésre utal vissza, hanem egy másik oklevélre (AO. 7: 328-330), amely ugyanazon a napon, 1358. augusztus 27 -én ugyanott, a budai káptalanban született. Mivel ugyanis a zágrábi püspöknek Mikcs bán fia István ellen benyújtott panasza ügyében Rajki Tamást küldték ki, az volt a legegyszerúbb, hogy egy másik, szintén e család elleni, de az elôzôtől független panasz ügyével is őt bízzák meg. 
Ez arra a rendkívül fontos funkcióra hívja fel a figyelmünket, hogy a nevek nemcsak egy szövegen belül, hanem szövegek között is képesek a visszautalásra. Ebben az esetben viszont a személyjelölő szerkezet változatlan, mindkét oklevélben ugyanazzal a de-s szerkezettel találkozunk. Ez nyilván nem véletlen: míg a szövegen belüli visszautaláskor az egyszerúbb szerkezet is elegendő az azonosításra, addig két szöveg között - az anaforikus szerepú névmás vagy participium mellett - éppen a szerkezet állandósága biztosítja az egyértelmű vonatkoztatást.

$\mathrm{Az}$ a tény, hogy erre a jelenségre mindössze egyetlen példát találtam, egyrészt arra utal, hogy a visszautalásnak ezt a módját meglehetősen ritkán alkalmazhatták a korabeli oklevelekben, másrészt pedig ismét felhívja figyelmünket a véletlen hatalmára. Ha ugyanis a két oklevél közül a korábban született nem maradt volna fenn, az idézett adatot egyszerūen a scriptor hibájának vélnénk, hiszen a predictus-nak és a névnek az adott szövegen belül nem található antecedense.

\subsection{A közszói eredetü megkülönböztető névelemek és családnevek elemzése}

A következőkben azokkal a névelemekkel foglalkozom, amelyeket a latin személyjelölő szerkezetekben dictus-szal vagy anélkül volt szokás kapcsolni. E megkülönböztető névelemek vagy családnevek motiváció szerinti megoszlását már a korábbi korpusz alapján is vizsgáltam: eszerint messze a legnépesebb kategória a külső tulajdonságot kifejező volt, ezt követte az etnikummal való kapcsolatot kifejező nevek csoportja (vö. SLÍz 2011b: 229-231). A továbbiakban a korábbi és az új korpuszt egyesítve, a jelenleg leggyakrabban használt magyar családnév-tipológia (funkcionálisszemantikai elemzési modell) alapján (vö. N. FODOR 2010: 74, CsnVégSz. 16) vizsgálom meg az egyes motivációs-jelentéstani kategóriák megterheltségét a különböző társadalmi rétegekben. Az alkalmazott tipológia kategóriái röviden:

1. hellyel való kapcsolat

2. személyekkel való, származásra utaló kapcsolat
a) apára utaló
b) anyára utaló
c) egyéb rokoni viszonyra utaló
d) nemzetségre utaló

3. néppel, népcsoporttal, nemzetiséggel való kapcsolatra utaló

4. társadalmi szerepre, helyzetre utaló

a) foglalkozásra, tisztségre utaló 
b) egyéb társadalmi viszonyra utaló

c) egyéb társadalmi kapcsolatra utaló

5. egyéni tulajdonságra utaló
a) külső tulajdonságra utaló
b) belső tulajdonságra utaló
c) valamilyen tulajdonságra metaforikusan utaló
d) járásmódra, beszédmódra, szavajárásra utaló
6. eseményre utaló

Az elemzéshez minden magyar és latin nyelvú megkülönböztető névelemet figyelembe vettem, amelyeknek felderíthető volt a közszói jelentésük, ezért a 7. kategóriára (ismeretlen motivációjúak) nem volt szükségem, kétrészes névelemek pedig nem fordultak elő a korpuszban.

Hogy a közszói jelentés felderítését mennyire megnehezíthetik az egymásnak ellentmondó adatok, arra, úgy vélem, elegendő lesz három szélsőséges példát bemutatnom. Az egyik esetben ugyanaz a személy dictus Kokas (1353, AO. 6: 141), Chokas (1353, AO. 6: 144) és Choka (1356, AO. 6: 483) megkülönböztető névelemmel is felbukkan az oklevelekben. Ezek alapján lehetetlen eldönteni, hogy Kakas vagy Csóka, Csókás lehet-e a név megfelelő olvasata. Ebben az esetben azonban - bármelyik olvasatot választjuk is - legalább a közszói eredetű, sôt egy szinttel lejjebb tekintve a metaforikusan utaló típuson belül maradunk, így a kategorizációt nem zavarja a bizonytalanság.

A következő eset azonban már nem ilyen szerencsés: ugyanaz a Pál nevú személy egyszer filius Petbuh (1351, AO. 5: 525), aztán dictus Potroh (1352, AO. 5: 556), majd dictus Powch (1353, AO. 6: 99) megkülönböztető névelemmel bukkan fel. E szerkezetek kapcsán felmerül a kérdés, hogy vajon a nevezett Pált Potroh-nak és a Pál becézőjeként vagy változataként Pócs-nak is szólították-e, netalán a Powch és a Potroh valamelyike ugyanazon névelem félrehallásával vagy elírásával, esetleg a scriptor reszemantizációs törekvésével jött-e létre. Sőt az sem zárható ki, hogy a Potroh a Pethub alakkal hozandó hasonló viszonyba, amennyiben nem a Péter változatáról van szó.

E feltételezések életszerú voltát támasztja alá a gáji Mocsk család genealógiában használt nevét adó, korábban már említett néhány adat: Dominico dicto M a c b k a filio Johannis de Zolyo (1349, AO. 5: 337) és Dominicus filius Mochk (1358, AO. 7: 487). Ebből ugyan még tévedésre is lehetne következtetni, de egyéb adatok igazolják, hogy Domokos apjának egyházi neve a János volt, emellett pedig a Mocsk nevet is használhatta. Logikusan adódik tehát a következtetés, hogy a Machkea nem az állat nevével utal metaforikusan valamely tulajdonságra, hanem az apa egyik egyénneve öröklődött tovább Domokosra is. Az írnok azonban feltehetőleg nem tudott vele mit kezdeni, ezért „értelmesítette”, azaz reszemantizációt hajtott végre. Ezt támasztja 
alá Domokos unokaöccsének egy 1413-as oklevélbeli megjelölése is, melyben a dicti Moczk adat szerepel (ENGEL 2003). Az ő két fiának a megkülönböztető néveleme azonban ismét zavarba ejtő: Miklós Mocbkos-ként, István pedig Moc₹kos-ként kerül elő (vö. ENGEL 2003). Ezek alapján az tűnik a legvalószínúbbnek, hogy a Mocsk név rendkívül ritkává válásával vagy eltűnésével ismeretlenné vált az írnokok számára, ezért az említett eljárással próbáltak „értelmet vinni” a névbe.

E két utóbbi eset már jóval nagyobb buktatóval járhat a tipologizálás során, hiszen némelyik adat alapján a tulajdonságra utalók, másokra támaszkodva viszont a személlyel való kapcsolatot kifejezők közé sorolnánk e neveket. Így az adathiány és a túl sok, egymásnak ellentmondó adat egyaránt vezethet a névelem félreértelmezéséhez, azaz téves kategorizálásához.

Mivel számos közszó több, egymástól független személyjelölő szerkezetben is megjelent (pl. fekete, vörös), külön megvizsgáltam a megoszlást mind az összes előfordulás, mind a névféleségek szempontjából. Sok névelem több kategóriába is besorolható, ezért az elemzésben az összes lehetséges motivációt figyelembe vettem. (A módszertani háttérről bővebben 1. N. FODOR 2010: 92-94).

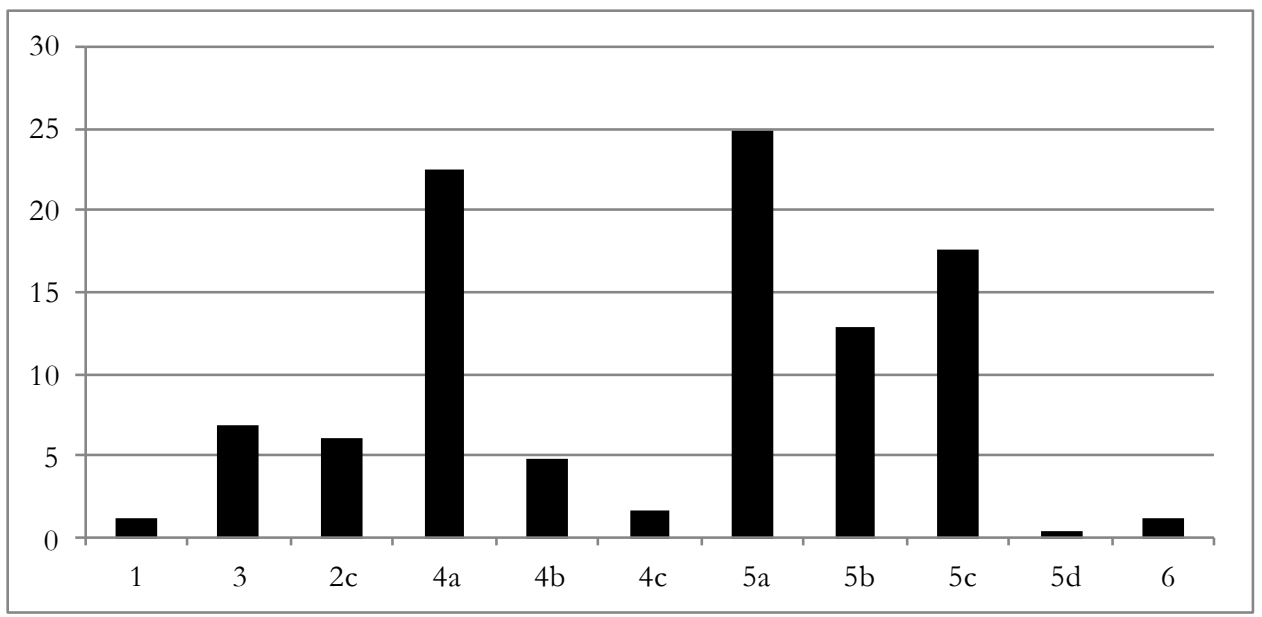

15. ábra: A közszói eredetű megkülönböztető névelemek megoszlása motiváció szerint (névféleségek)

A 15. ábra az egyesített korpusz 249-féle közszói eredetú, világos közszói jelentésú megkülönböztető névelemének motivációs kategóriák szerinti megoszlását ábrázolja. Ez részben megerősíti a korábbi eredményeket: a legnépesebb csoportot továbbra is a külső tulajdonságra utalók alkotják. Ezt azonban alig lemaradva a foglalkozásra, tisztségre utalók követik, a harmadik leggyakoribb pedig a tulajdonságra 
metaforikusan utaló nevek csoportja (ez legnagyobb számban növény- és állatneveket tartalmaz).

Mivel a vizsgált anyagból kizártam azokat a szerkezeteket, amelyekben a dictus személy- vagy helynevet kapcsol az egyénnévhez, a hellyel és a személlyel való kapcsolatot kifejező kategória érthető módon csekély arányban képviselteti magát az anyagban; e két viszonyt ugyanis jellemzőbben más szerkezetek fejezik ki a latinban (filius-os, illetve de-s szerkezetek). A rostán így fennmaradt, személyhez való kapcsolatot kifejező közszói névelemek többnyire valamilyen családi állapotot, viszonyt fejeznek ki, pl. Nicolao dicto A rw a (1352, AO. 5: 568), Pauli dicti Fy w (1358, AO. 7: 520). A helyre utalónak is tartható két közszói eredetû́ névelem a Szél és a Hegyi: Petrus dictus $Z$ ee l (1318, AO. 1: 473), Andree dicti Hegy de Ilka (1350, AO. 5: 405).

Ha társadalmi rétegenként is megvizsgáljuk a névelemek megoszlását, összetettebb kép bontakozik ki előttünk (16. ábra). Eszerint a külső tulajdonságra utaló csoport, bár a polgárság kivételével mindenütt a legmegterheltebb, leginkább a jobbágyságra jellemző. Nem véletlen, hogy a mezôvárosiak alig maradnak el mögöttük, hiszen e várostípus lakossága jórészt a falvakból, földesúri birtokokról beköltözött, jogilag továbbra is jobbágynak számító elemekből állt. Szintén nem meglepő, hogy a kézmúipar, a bányászat és a kereskedelem központjaiként múködő városok polgársága körében a foglalkozás- és tisztségnévi eredetű névelemek alkotják a relatív többséget. Kevésbé érthető első pillantásra e kategória viszonylag magas aránya a birtokosok körében, hiszen e réteg tagjai nem űztek semmiféle foglalkozást. A csoport elemeit megnézve azonban világossá válik, hogy ez az arány a méltóságot, tisztséget kifejezô névelemeknek köszönhető, pl. Peteu Tarnuk dictum (1332, AO. 2: 614), Stephani dicti Aproud (1358, AO. 7: 247). ${ }^{37}$

A birtokosok körében a második legmegterheltebb kategória a metaforikusan tulajdonságot kifejező, míg érdekes módon ez más rétegekben kevésbé jellemző. Ezzel szemben a birtokosok körében a legalacsonyabb a helyre és a személlyel való rokoni kapcsolatra utaló névelemek aránya. E két jelenség szorosan összefügg, magyarázatuk pedig a személyjelölő szerkezetek fentebb látott rétegenkénti megoszlásában keresendő: a közszói eredetű névelem a birtokosok körében a legkevésbé jellemző;

${ }^{37}$ A kategorizáció során ugyanis - amely nevek esetében lehetett - a CsnVégSz. szerinti besorolást vettem alapul, a foglalkozás- és méltóságneveket együtt szerepeltetve. Bár alapvetően egyetértek GULYÁS LÁSZLÓ SZABOLCS (2015) eljárásával, aki legutóbbi munkájában a névtani szakirodalomnál jóval szűkebben értelmezte a foglalkozásnévi kategóriát, a későbbi, történeti családnév-tipológiai vizsgálatok érdekében (1. pl. a foglalkozásnevek kapcsán: SLíz 2015b, 2016b) mégis a tágabb értelmezést követtem. Mivel ugyanis a későbbi korszakok családnévanyagára vonatkozó vizsgálatok is ezt követik, egy ettől eltérő kategorizáció nem tenné lehetővé az egyes korszakok tipológiai szempontú, megterheltség szerinti összehasonlítását. 
náluk a filius-szal jelölt személy-, illetve a de-vel kifejezett helyneves szerkezetek voltak a jellemzőbbek.

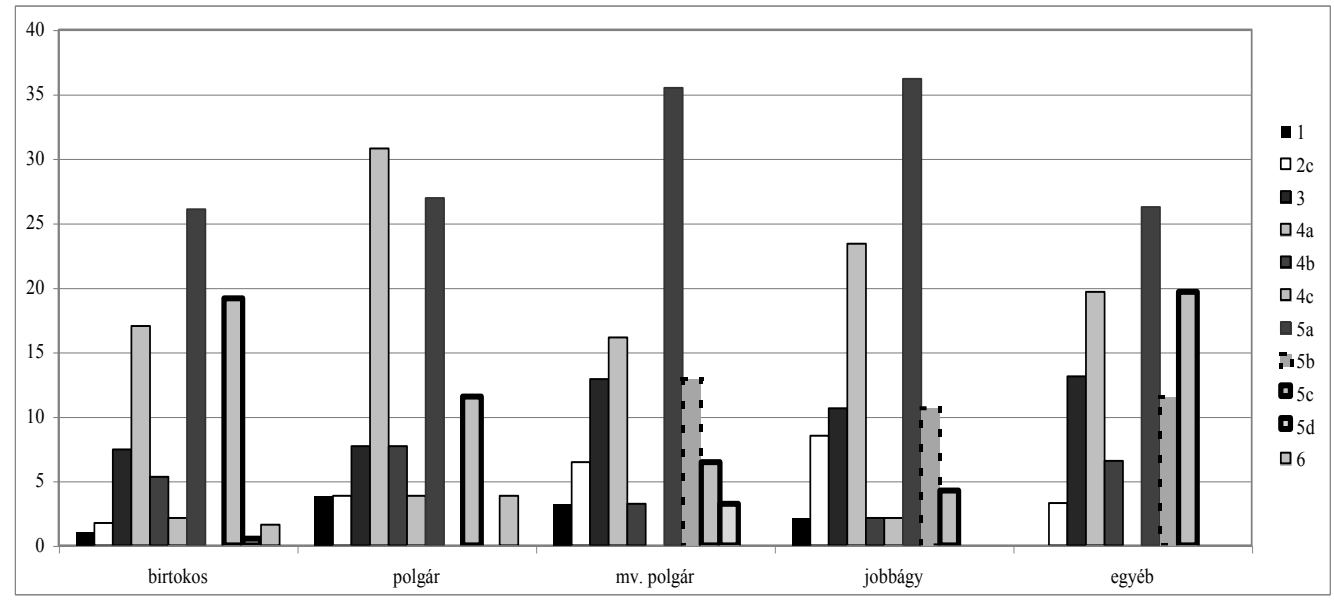

16. ábra: A közszói eredetű névelemek motiváció és réteg szerinti megoszlása (névpéldányok)

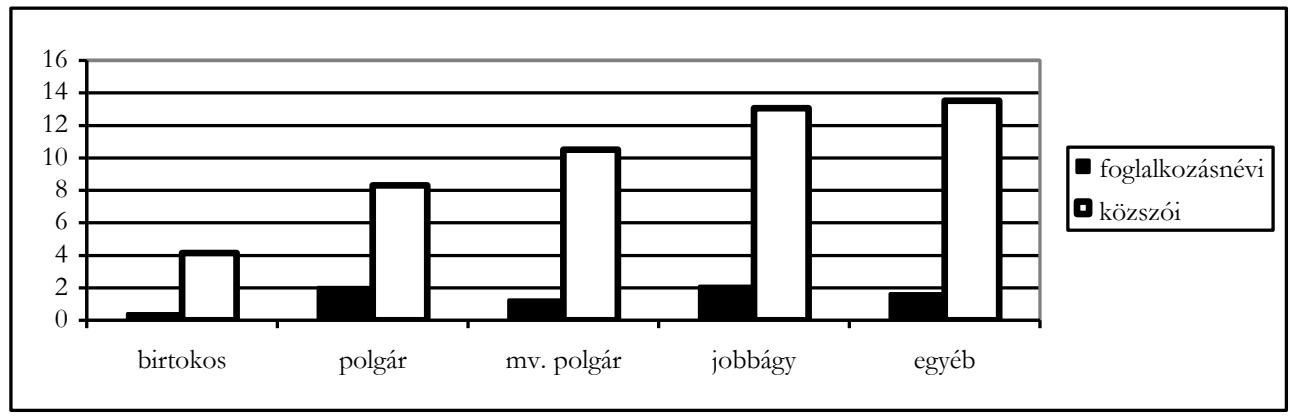

17. ábra: A közszói eredetű és a foglalkozásra utaló névelemek megterheltségének rétegenkénti megoszlása

A 17. ábrán jól látszik, hogy amint lefelé haladunk a társadalmi ranglétrán, egyre nő a közszói eredetû névelemek aránya. Ez lehet tehát a második magyarázat a dictus-os szerkezeteknek a filius-os és de-s szerkezetekhez képest jelentős mértékben alacsonyabb arányára (vö. 11. ábra): a korpusz ugyanis, mint korábban kiderült, túlnyomórészt birtokosok névanyagát tartalmazza. Ebből pedig egyenesen következik a feltevés, hogy a dictus-os szerkezetek alacsony arányában a társadalmi szempontból 
egyenetlen forrásadottságok miatti torzítás is szerepet játszik, s az egyenletesebb eloszlás feltehetőleg e személyjelölő szerkezettípus magasabb arányát mutatná.

A foglalkozásnévi kategóriát a 17. ábra ismeretében ismét megvizsgálva a fentiektől egészen eltérő kép rajzolódik ki előttünk, mely már megfelel előfeltevéseinknek: e motivációs-jelentéstani típus aránya a birtokos rétegben a legalacsonyabb, míg a legmagasabb - a korábban látottal ellentétben - a jobbágyok körében. Ennek az eltérésnek az oka a foglalkozásnévi eredetű megkülönböztető névelemek állományának változatosságában rejlik: míg a falvakban kevesebb foglalkozás volt jelen, és azok is jellemzően inkább a mezőgazdasághoz vagy az olyan mesterségekhez kötődtek, amelyeknek a termékeire mindenhol szükség volt (pl. 1354: Thome Kapas dicti, AO. 6: 227; 1358: Johannes dictus Molnos, AO. 7: 516), addig a városok jóval differenciáltabb kézmúipara változatosabb névállományt, vagyis több névféleséget eredményezett (pl. 1345: Nicolai dicti Fogy as, AO. 4: 548; 1358: Jacobi dicti Ny lg a rto, AO. 7: 525). (A foglalkozásnévi eredetú megkülönböztetô névelemek és családnevek gyakoriságáról, társadalmi, területi megoszlásáról és annak változásáról bővebben 1. SLÍZ 2016b.)

Ha nem névpéldányonként, hanem megterheltség szerint vizsgáljuk meg a közszói eredetû névelemek jelentéstani típusainak társadalmi megoszlását (18. ábra), akkor a külső tulajdonságra utaló csoport még dominánsabb szerepével szembesülünk minden rétegben, most már a polgárság körében is. Ez néhány tipikus, külső tulajdonságra utaló névelem minden rétegben megfigyelhető gyakoriságának a következménye: vörös-ből 38, fodor-ból 17, feketé-ből 16, fehér-ből 12, orros-ból 7, szakállasból és szókeé-ből 6-6 fordul elő a korpuszban.

A népre, népcsoportra, etnikumra utaló névelemekre szintén érdemes egy pillantást vetnünk. A 18. ábra szerint e csoport a névféleségek számát tekintve csupán az 5. volt a gyakorisági sorrendben. Ennek oka könnyen belátható: ez a kategória a többihez képest kisebb és véges elemszámú. Akár a névpéldányok számát (16. ábra), akár a megterheltségüket nézzük (18. ábra), első pillantásra talán meglepő módon az azonosithatatlan vagy besorolhatatlan személyek neveit tartalmazó csoportban mutatkozik a legmagasabbnak az arányuk. Ha azonban tudjuk, hogy a népnévi eredetú nevek gyakran (de nem szükségszerűen) utalhatnak mobilitásra (akár allogén származás, akár a más népekkel való érintkezés révén), akkor érthetôvé válik, hogy éppen a legmobilisabb, uraikat messze földre is követő familiarisokat, officialisokat nagy számban tartalmazó csoportra jellemző leginkább e névtípus.

A korpuszban előforduló, népre, népcsoportra vagy etnikumra utaló megkülönböztető névelemek (zárójelben korpuszbeli gyakoriságukkal): Tót (11); Német (8); Besenyö, Cseh, Székely, Szláv (7); Kun (4); Magyar (3); Horvát, Lengyel, Tatár (2); Bajor, Olasz, Orosz, Szász (1). A CsnSz. első adatát csaknem 20 évvel megelőző Olasz (1357: Ladislaus filius Johannis dicti O la z de Berzel, AO. 6: 528) feltehetőleg a latin Gallicus-szal együtt (1345: uxor Andree Gallici filii Johannis, AO. 4: 546) még 'nyugati újlatin nyelvet beszélő' jelentésben szerepel itt (bővebben 1. RÁCZ 2009: 86-89). Ugyanakkor 
a TESz. már a Jókai-kódexből adatolja a mainak megfelelő szúkebb, 'itáliai' jelentést, így nem zárható ki, hogy esetünkben a Gallicus 'vallon', az Olasz pedig már 'itáliai' jelentést hordoz. Az Orosz szintén kérdéses lehet: feltehetőleg nem a mai jelentésében, hanem 'ruszin'-ként értendő, bár nem zárható ki az sem, hogy etnikum helyett (ortodox) vallásra utal.

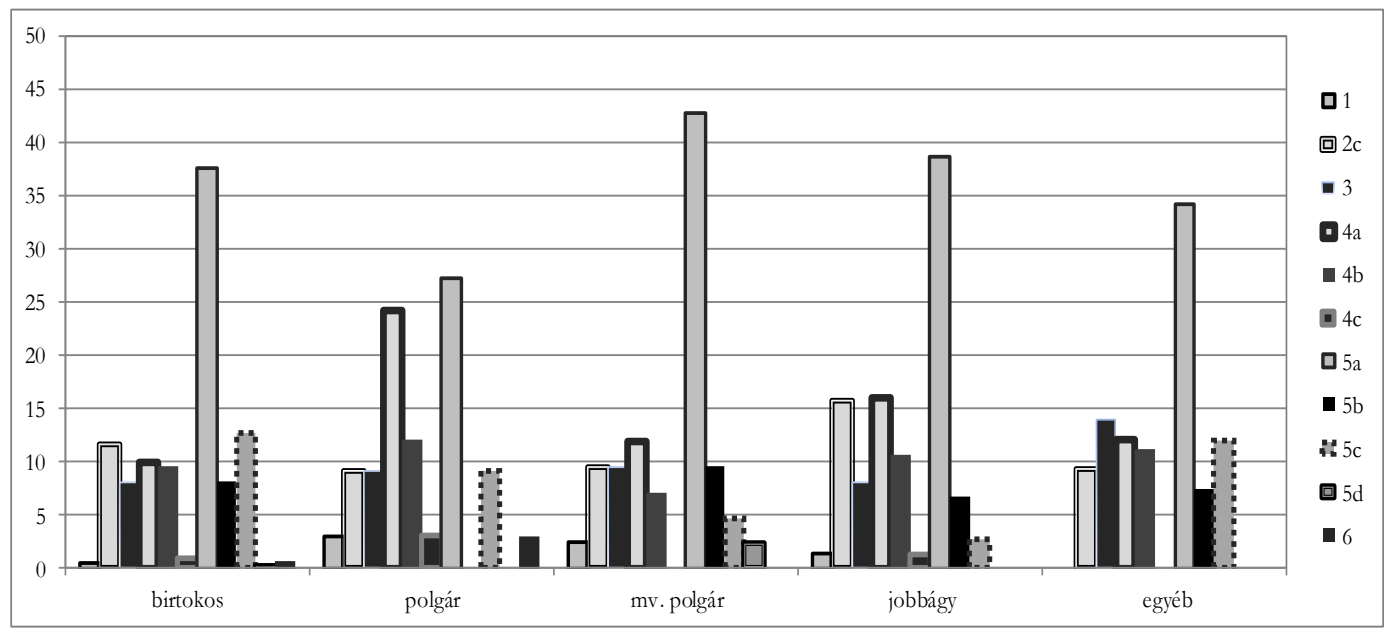

18. ábra: A közszói eredetű megkülönböztető névelemek megterheltségének kategóriák és társadalmi rétegek szerinti megoszlása

Mint látható, a több nyelvre, illetve népcsoportra összefoglalóan utaló nevek (pl. Tót 'szláv', Német) általában valamivel gyakoribbak, mint az egy adott csoportra, etnikumra utalók. Különösen, ha a Tót-hoz hozzászámoljuk a latinul slavus-ként megnevezett hét személy nevét is. A korpuszbeli gyakorisági sorrend némileg különbözik napjainkétól, az azonban figyelemre méltó, hogy a kis adatmennyiség ellenére jelentôs hasonlóságok is megfigyelhetôk. Így az élen álló Tót jelenleg is a leggyakoribb népnévi eredetủ családnév, a 14. századi lista 2. helyén álló Német pedig napjainkban a 3. helyet foglalja el a népnévi eredetű családnevek gyakoriság szerinti sorrendjében (a jelenkori listára, illetve a népnévi eredetú családnevek típusára, annak történeti változásaira l. FARKAS 2013). Az itt még 3. helyen álló Besenyő ugyanakkor meg sem jelenik az újabb magyar kor gyakoribb népnévi eredetú családnevei között, és a Tatár is csak a 17. a mai listán, míg a mai lista 4. helyét elfoglaló Oláh egyáltalán nem bukkant fel a korpuszban. E különbségek oka nyilvánvalóan a 14. századi és a későbbi etnikai viszonyok közötti eltérés: a besenyók a 14. század végére, illetve a 15. századra, azaz a családnevek kialakulásának korára már csaknem teljesen asszimilálódtak, a tatárokkal sosem volt olyan mélységú, hosszú idejű, széles körű és 
sokrétủ a magyarság kapcsolata, mint a németekkel vagy a szláv népekkel, a románok elődei pedig a 14. század elején még friss betelepülőnek számítottak Erdélyben.

\subsection{A nők megjelölése az oklevelekben}

\subsubsection{A latin nyelvű oklevelek tanúsága}

Mint korábbi munkámban részletesen bemutattam (SLÍZ 2011b: 218-222), a nők oklevélbeli megnevezése alapvetően eltért a férfiakétól: az ő megjelölésükben nem találkozunk megkülönböztetôn névelemmel vagy családnévvel, és többnyire valamely rokonukhoz viszonyítják őket. A következőkben az egyesített korpusz alapján mutatom be azokat a variációkat, amelyek előfordultak az oklevelekben a nők megnevezésére. Az alábbi listában - a gyakoriság sorrendjében - az előfordulás darabszámával együtt azt tüntetem fel, mely rokon neve szerepelt a körülírásban. Mivel a teljes korpuszban hajadonok és férjes asszonyok is szerepelnek, az előbbiek megjelölésére azonban férj és gyermek hiányában érthetô módon kevesebb választási lehetőség volt, ezért igyekeztem kiszűrni azokat, akik biztosan nem voltak még házasok. A zárójeles szám ebből következően a hajadonok kiszűrése után megmaradt esetek mennyiségét adja meg. A lista értelemzéséhez tudni kell még, hogy azt a személyt nem vettem figyelembe, akinek az ügyben szereplő társaként vagy képviseltjeként szerepelt a nő az oklevélben. Az afféle esetekben ugyanis, mint a domina Olus consorte sua, filia dicti Ewngini (1358, AO. 7: 366), a férj nem ugyanolyan szerepet tölt be, mint például a nobilis domina nomine Katerina filia Comitis Radolf uxor magistri Jacobi filij Comitis Leonardi (1310, AO. 1: 214) körülírásban. Az utóbbiban ugyanis elhagyható lett volna a férj megjelölése, mivel nincs egyéb szerepe, mint a nô adott családhoz tartozásának a kifejezése. Az elóbbiben ezzel szemben a férj neve a feleségéénél korábban bukkan fel az oklevélben, így a nő hozzá való viszonyítása (consorte sua) a szövegösszefüggés megteremtésének, a visszautalásnak az eszköze, így nem is hagyható el. A következőkben az ilyen, a szövegösszefüggés biztosítására szolgáló elemeket nem vettem figyelembe. Az összesített korpuszban tehát a viszonyításoknak a következő kombinációi fordultak elő:

apa: 145 (123)

férj: 127

apa + féri: 96

senkihez sem viszonyították: 21 (13)

apa + elhunyt férj + jelenlegi férj: 8

apa + testvér: 8 


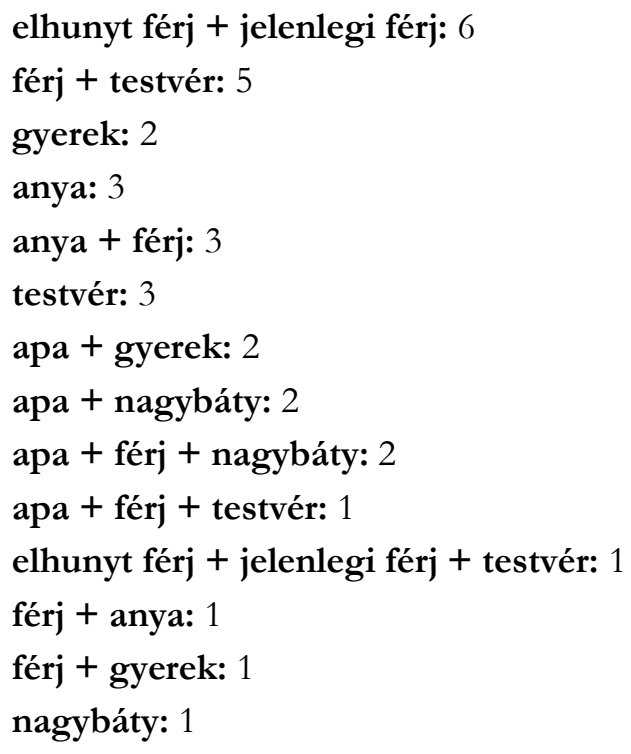

Mint látható, a férjes asszonyok megnevezésében szinte ugyanannyiszor fordul elő kizárólag az apára vagy a férjre való utalás, a harmadik leggyakoribb típus pedig mindkettőjük megjelölése. A többi variáció ezeknél nagyságrendekkel ritkábban fordul csak elő, habár a viszonyítás nélküli, pusztán egyénnévvel való megjelölés is viszonylag gyakorinak bizonyult. Ennek az az oka, hogy - mint azt korábbi munkámban már kimutattam (SLÍZ 2011b: 222) - ezzel a megoldással elsôsorban a jobbágyok, illetve a szolgálók megjelölésekor éltek, így ezek többsége ebbe a kategóriába került, s e kategóriát nagyobbrészt az ô neveik alkotják: egy apáca, két nemes és három polgárasszony mellett egy jobbágy és tizenöt szolga neve szerepel közöttük.

A többi típus ritkaságára az egyik magyarázat az, hogy míg az apához és férjhez való viszonyítás mindig lehetséges a házas nők esetében, addig nagybátyja, testvére, gyermeke vagy korábbi férje nem mindegyiküknek volt. Az anyához való viszonyítás pedig azért jellemző ilyen kevéssé, mert azon ritka esetekben fordul elő, amikor az anya - többnyire özvegy lévén - nem valamely férfirokonával képviselteti magát, és nem hozzájárul valaminek az eladásához, megvételéhez, örökítéséhez stb., mint az oklevelek többségében, hanem önálló cselekvőként vesz részt az ügyben. A másik ok pedig az lehet, hogy a rokonok megjelenése a körülírásban erősen függ a szóban forgó ügytől és annak résztvevőitől is. Így például ha az anyát, nagyanyát stb. megilletô leánynegyed kerül szóba, érthetô módon megjelenik a gyermek is a viszonyításban, pl. 1356: super quarta filiali [...] Elizabet vocate, matris [...] condam comitis Nicolai avi eorumdem (AO. 6: 522).

Bár az oklevelekben a férfinevekhez képest igen kevés a női nevek száma, mégis előfordulnak olyan szerencsés esetek, amikor ugyanannak a nőnek a megnevezése 
több oklevélben is felbukkan. Ezek összevetése a férfineveknél látottakhoz hasonlóan lehetôséget nyújt számunkra a fenti állítás igazolására, vagyis annak megvizsgálására, hogy a szóban forgó ügy és annak szereplői miként befolyásolták a nők megjelölését az oklevelekben. Bár a korpuszban nem egy ilyen eset van, a legdokumentáltabb kétségtelenül Magyar Pál gyimesi várnagy feleségének az élete, ezért az ő megjelöléseit választottam e vizsgálat alapjául. Magyar Pálné nevének oklevelekben való gyakori megjelenése azzal magyarázható, hogy fiúsított lány lévén jelentős vagyon és birtokok fölött rendelkezett önállóan, ́́gy gyakrabban vett részt jogi cselekményekben, mint kortársai. Fiúsításának oka szintén egyedülálló: 1316-ban, mivel a Nádasd nemzetség Pető-ága a tartományurak elleni harcban Károly Róbert mellett állt, Köszegi János szinte teljesen kiirtotta őket, gersei udvarházukat rágyújtva a családra. Csupán egy Margit nevü kisgyermeket tudott megmenteni a dajkája, Károly Róbert pedig 1332-ben, az országban akkor még ismeretlen módon fiúsította az idôközben felnőtt lányt, a családi vagyon mellett további adományokkal gazdagítva a házaspárt. (Vö. KARÁCSONYI 1900/20042: 849-850.) Ezzel a király utólag is elismerte és honorálta a család támogatását, mintegy elégtételt adva az utolsó élő leszármazottnak. Emellett lépése része volt annak a tudatos politikának is, amelynek jegyében az előkelő és gazdag elárvult lányokat az Anjouk saját feltörekvő híveikhez adták hozzá, így segítve anyagilag és társadalmi kapcsolatok révén azok emelkedését a ranglétrán, egyszersmind biztosítva maguknak további húségüket (vö. KuRCZ 1988: 73).

A korpuszban elsóként előforduló említés azon oklevélből való, amelyben Magyar Pál végrendeletileg számos birtokot hagy feleségére és lányára: dominarum Margarethe consortis sue et Helizabet filie sue (1344, AO. 4: 479-480). A rendelkezés szempontjából egyedül az számít, hogy Margit milyen rokoni kapcsolatban áll a rendelkezôvel, így semmilyen további viszonyítás, egyéb hozzátartozóra való utalás nem szerepel a nô megjelölésében. Egy 1353-as oklevélben ezzel szemben mind az apához, mind a férjhez való viszonyítás megjelenik, sőt az apa személyjelölő szerkezetében a nagyapa és a dédapa neve is szerepel: nobilis domine Margareta nuncupate filie Ladislai filii Andree filii Chapou consortis magistri Pauli dicti Magyar (AO. 6: 127). Ennek a részletező körülírásnak a célja minden bizonnyal annak a kifejezésre juttatása, hogy a Margit által az oklevélben az óbudai klarisszákra hagyott birtokok, köztük maga Gerse az apjáról, rajta keresztül pedig az egész Petőágról szálltak rá örökségként, így jogosan rendelkezik felettük önállóan.

Végezetül érdemes még kitérni arra a kérdésre, hogy e körülírásokon belül hol helyezkedett el a nő egyénneve. A latinban ugyanis három lehetőség is adódik. Állhat a körülírás elején, vagyis az összes viszonyító elem előtt, pl. nobilis domine Stephany a vocata, neptis magistri Conrardi filij Stephani de Owar filie Georgy filij sinistri Nycolai Relicte [...] Nycolai filij Belud (1302, AO. 1: 37). Állhat középen, két viszonyító elem között is, mint az alábbi példában az apa és az elhunyt férj megjelölése között: nobilis domina filia [...] Benedicti filii Detrici calvi $A n n$ a vocata relicta quondam Nicolai dicti Forgach (1337, AO. 3: 432-433). Végül állhat az összes viszonyító elem mögött, 
hátravetve is: nobilis domina relicta Andree Rufi filii Demencs de Geley et filia Mark condam de Abram [...] Ka terin a vocata (1354, AO. 6: 178).

A női névadatokat e szempontból vizsgálva azokat a körülírásokat is figyelembe vettem, amelyeket korábban, a viszonyító elemek típusai kapcsán kizártam, hiszen jelen kérdés kapcsán nem releváns az, hogy egy elem kötelezően fordul-e elő az egyénnév mellett. Az efféle megjelölésekben ugyanis az egyénnév ugyanúgy állhat elöl vagy hátul, vö. pl. elöl: pro domina Margareta filia sua (1354, AO. 6: 217); hátul: domine sororis sue Kynge nominate (1325, AO. 2: 213). Az összes, figyelembe vehető, vagyis valamiféle viszonyító elemet tartalmazó körülírást (552 db) e szempontból áttekintve az rajzolódik ki, hogy bár az egyénnév legjellemzőbben elöl helyezkedik el bennük, 133 esetben, vagyis csaknem a körülírások negyedében (24\%) hátravetve találjuk. Ez a nem elhanyagolható arány véleményem szerint ugyanúgy a nőknek a korabeli társadalomban betöltött szerepét, annak a férfiakéhoz képest korlátozottabb voltát jelzik; akárcsak azok a megjelölések, amelyek a nőkre egyénnevük közlése nélkül, csupán valamely férfi hozzátartozójuknak a megnevezésével utalnak. Emellett persze a hátravetett egyénnevek arra is újabb bizonyítékul szolgálnak, hogy e körülírásokban a férfinevekkel ellentétben még nem fordulnak elő családnevek vagy azok előzményei.

\subsubsection{A német nyelvű oklevelek tanúsága}

A latin oklevelekben alkalmazott eljárások áttekintése után tanulságos lehet a soproni német nyelvű oklevelekben is megvizsgálni a nők megjelölését. Ezek a források ugyan 50-100 évvel később születtek, mint latin nyelvű korpuszom adatai, de a németekkel egykorú latin oklevelek szerint ez idő alatt nem történt különösebb változás a latin oklevélírásban a nők jelölését tekintve; így a következő példában Katalint ugyanúgy a korábban elhunyt és a második férje megnevezésével jelölték meg, ahogyan az a 14. század első felében volt szokás: in persona nobilis domine Katherine alias relicte Ladislai filii Dyonisii de Harka, nunc vero consortis Thome filii Nicolai de Syrak (1425, SoprT. I/2: 283). Ezért a két korpusz összevetésében az időtényező okozta különbségekkel nem kell számolnunk, így az eltéréseket egyértelmúen a nyelvi különbségnek tulajdoníthatjuk.

Az összevetés alapján azonban nem annyira a különbségek, mint inkább a feltűnő hasonlóságok rajzolódnak ki a két forráscsoportban alkalmazott eljárások között. A német nyelvű oklevelekre ugyanis szintén az volt a jellemző, hogy a nőket valamely (többnyire férfi-)rokonukhoz viszonyítva jelölték meg. Az eltérés mindössze annyi, hogy a soproni oklevelekben rövidebb körülírásokat találunk. Házas nők esetében például az apjuk neve igen ritkán jelenik meg; jellemzően a férj volt a viszonyítás alapja; pl. fraun Elsbeten, Stephans des Seltenpekechen hausfraun; fraun Katbrein, Niklass des Hanifvogels hausfraun; fraun Elsbeten, Stephan des Walichs hausfraun (1418, 
SoprT. I/2: 151). Ezekben a példákban a nők maguk voltak az ügy szereplői. Amikor férjükkel együtt szerepelnek, általában csupán az egyénnevük és a viszonyító elem (sein hawsfraw 'a felesége') szerepel az oklevélben: Ich Mert der Greyner, purger czu Odenbürg, vnd ich Angnes sein haw sfraw 'Én, Mert ['Márton'] Greyner soproni polgár és én, Agnes, a felesége' (1414, SoprT. I/2: 86). Ha mégis több férfirokon szerepel a körülírásban, azt a külső körülmények indokolják. A következő esetben például az, hogy az oklevélben ígéretet tevő férfi a testvére özvegyével együtt nyilatkozik. Mivel az asszony másodszor is férjhez ment, az elhunyt férj neve a kettejük közti rokoni kapcsolat világossá tétele érdekében kerülhetett a forrásba: Vrsula, Conrats des Preïssen hausfraw vnd weilend den benanten Thomann von Schadendorff 'Ursula, Conrad Preuss felesége és a néhai Thomas Schadendorf özvegye' (1448, SoprT. I/3: 270).

A nyelvi eltérés ellenére tehát a latin oklevélírási hagyománynak a németre gyakorolt hatása e téren is érzékelhetô. Emellett azonban egy másik oka is lehet a nagyfokú hasonlóságnak. Az ugyanis, hogy a soproni német nyelvú oklevelekben sem igen lehet nőt jelölő családnévre bukkanni (kivéve a nem magyarországiakat), alátámasztja a latin oklevelekből nyert eredményeket, melyek szerint a családnevek nők esetében való használata a férfiak esetében tapasztaltnál későbbi, ezek szerint feltehetőleg még a 15. század első felénél is újabb fejlemény lehet. 


\section{SZEMÉLYNEVEK FORDÍTÁSA KÉSEI ÓMAGYAR KORI OKLEVELEKBEN}

\subsection{A személynevek fordításáról általában}

A vulgáris nyelvű tulajdonneveknek a latin nyelvű, valamint a más vulgáris nyelven íródott oklevelekbe való bekerülése nemcsak névtörténeti, hanem fordítástudományi kérdés is. Ezért a következőkben azt tekintem át, hogy a személynevek fordítása során milyen stratégiákat alkalmazhattak a scriptorok a különböző nyelvú oklevelekben.

A tulajdonnevek fordításának kérdése a fordítástudomány egyik speciális területe, melyre az utóbbi évtizedben a magyar névkutatás egyre nagyobb figyelmet fordít. Mivel a fordítási gyakorlat időben is változik, ráadásul névfajtánként és nyelvenként is eltérő, emellett pedig erősen alá van vetve a hagyománynak, illetve a szövegkörnyezetnek és a szituációnak, a szakirodalom rendkívül szerteágazó. Egyes írások általános kérdésekkel (pl. J. SOLTÉSZ 1979: 118-123, HAJDÚ 2003: 143-145, VÁRNAI 2005: 77-84, VERMES 2005a, FARKAS 2007, 2009a, 2011), mások egy-egy névfajtát érintő problémákkal foglalkoznak (pl. helynevek: BÖLCSKEI 2009, 2010b; személynevek: HORVÁTH 2008, FARKAS-SLÍZ 2013). A munkák egy része a szakfordításra (pl. HorvÁtH 2008, RiHMER 2008), illetve az irodalmi múvekben előforduló nevek fordítására koncentrál (pl. FÁBIÁN 2004, BAKONYI 2008, HERTELENDY 2011, BÁRCZI Zs. 2013, FARKAS-SLÍZ 2013: 10-12), mások a többnyelvú környezetből adódó névkontaktológiai, kisebbségkutatási, névjoggal is összefüggő, a fordítási kérdéseken már túlvezetô problémákat állítják a középpontba (a személynevek kapcsán pl. FARKAS 2009b, 2009c, BEREGSZÁSZI-CSERNICSKÓ 2011, VÖRÖS 2012; a helynevek kapcsán pl. TÖRÖK 2012, ANGYAL 2013, PERGER 2013). A vizsgálódás általában napjaink, illetve a közelebbi múlt fordítási gyakorlatára irányul, s kevesebb tanulmány fordul a diakrón szempontok felé (ez utóbbira l. pl. FARKAS-SLíz 2013). A következőkben e hiányosságot igyekszem legalább részben, egy adott korszak és forrástípus vizsgálatával pótolni.

\subsection{A vizsgálat célja és forrásai}

E fejezet témája a fent említett lehetséges vizsgálati szempontok közül többet is érvényesít: egy adott névfajtának, a személynévnek a fordítására összpontosít, és szó 
esik benne egyrészt a fordítási gyakorlat időbeli változásáról, másrészt a különféle nyelvek fordítási gyakorlatában megfigyelhető eltérésekről. Forrásként az egyesített korpusz mellett a korábban már használt, Sopron szabad királyi város története címú munkában (SoprT.) található német nyelvű okleveleket, valamint a KNIEZSA ISTVÁN által összeállított és kiadott Középkori cseh oklevelek (1952) címú kötetet használom fel. A 14. századi, latin nyelvú forrásokból összeállított korpuszt - annak érdekében, hogy a 15-16. századi német és cseh oklevelekkel egykorú adatokra is támaszkodhassak - N. FODOR JÁNOS 15-16. századi felső-Tisza-vidéki anyagot tartalmazó névtárából (FTSznSz.), Bács, Bodrog és Csongrád megye 1522-es dézsmalajstromaiból (SZABÓ 1954), valamint az 1524-es veszprémi urbáriumból (VeszprUrb.) származó adatokkal egészítem ki.

A német és cseh nyelven írt oklevelekre mindeddig nagyságrendekkel kevesebb figyelem irányult a névkutatásban, mint a latin nyelvúekre. A német nyelvúek névadatainak módszeres összegyújtésére és átfogó vizsgálatára jelen vizsgálat során én sem vállalkozhattam az oklevelek nagy száma miatt, ezért a bennük szereplő nevek fordítására vonatkozó megfigyelések inkább csak az esetleges későbbi kutatásokat megelőlegező kiindulópontként, illetve a latin nyelvű oklevelek kapcsán tett megállapítások melletti kitekintésként, a teljes képet árnyaló háttérként szolgálnak. A cseh oklevelek ezzel szemben kis számuk és szûk időhatáruk, illetve a bennük előforduló, jelen munkában figyelembe vehetô adatok kis mennyisége miatt nem nyújtanak lehetôséget a latin oklevelekéhez hasonló részletességú vizsgálatra.

\subsection{Módszertani kérdések}

\subsubsection{A scriptorok többnyelvüsége}

A fordítás vizsgálata kapcsán nem lehet megkerülni a többnyelvűség ${ }^{38}$ kérdését, hiszen a fordítás nem működhet legalább két nyelv (nem feltétlenül anyanyelvi szintű) ismerete nélkül. A latin, német és cseh oklevelek fordítása kapcsán két kérdés merülhet fel: 1. Mennyire bírhatta a scriptor a forrásnyelvet, azaz esetünkben a magyart, illetve mennyire a célnyelvet, azaz a latint, németet és csehet? 2. Kétnyelvűsége spontán vagy kulturális jellegû volt-e? Ezekre természetesen oklevelenként, tehát scriptoronként eltérő válasz adható. Azt azonban általánosságban érdemes megjegyeznünk, hogy míg a latin esetében biztosan kulturális kétnyelvűséggel kell

38 A kétnyelvűség számos felfogása közül a következőkben a funkcióközpontú meghatározást veszem alapul. Eszerint „kétnyelvű az, aki a mindennapi érintkezései során két vagy több nyelvet kommunikatív, szociokulturális szükségleteinek megfelelően (szóban és/vagy írásban, illetőleg jelelt formában) rendszeresen használ” (BARTHA 1999: 40). 
számolnunk, addig a német és a cseh akár a scriptor anyanyelve is lehetett. A német anyanyelvűek születhettek valamely magyarországi, németek által (is) lakott városban, illetve bajor és osztrák területről is érkezhettek, a csehek viszont jellemzően külföldiek voltak; azt legalábbis tudjuk, hogy Luxemburgi Zsigmond a magyarok mellett cseheket és németeket is alkalmazott a királyi kancellárián (vö. MOLLAY 1982: 120-121). A hazai születésű német scriptorok feltehetőleg spontán németmagyar kétnyelvűek lehettek, hiszen valamilyen mértékben bizonyára még a német többségű városokban is érték őket magyar nyelvi hatások; a külföldről érkező német anyanyelvűek és a csehek esetében viszont a kulturális kétnyelvűség a legvalószínúbb feltételezés.

Mivel ugyanis az oklevelet a jegyzőnek az érintettek számára, azok nyelvén is tolmácsolnia kellett (vö. a latin kapcsán: BALÁzS 1989: 102), a külföldrôl érkező jegyzők is kénytelenek voltak valamilyen mértékben elsajátítani a magyart. Nyelvtanulásukat szójegyzékek segíthették; ezek másolataiból több is fennmaradt. A Soproni szójegyzéket például, mint mai megnevezése is sejteti, a Bécsből származó Ernst Konrád vezető nótárius soproni városi kancelláriáján használták a 15. században (vö. pl. MOLLAY 1982: 137). Mindezekből természetesen következik, hogy a korabeli Magyarország német vagy cseh anyanyelvű értelmisége esetében tulajdonképpen nem is két-, hanem legalább háromnyelvűségről kell beszélnünk, hiszen a német vagy cseh és a magyar mellett mindegyikük elsajátította a latint is. Ami pedig a magyar anyanyelvüeket illeti, a hazai német etnikummal való együttélés révén spontán kétnyelvüek is lehettek, de a külföldi egyetemjárás során is elsajátíthatták a másik nyelvet. Közöttük ugyanakkor természetesen olyanok is lehettek, akik a magyar és a latin mellett nem beszéltek más nyelvet, vagyis míg a német és cseh anyanyelvű scriptorok háromnyelvűségében csaknem biztosak lehetünk, addig a magyarok esetében csupán a magyar-latin kulturális kétnyelvűséget vehetjük biztosra. A korabeli hivatásos írástudók nyelvtudásáról alkotott kép tehát, mint látjuk, meglehetősen összetett, és számos bizonytalanságot rejt; kérdés tehát, hogy az elmondottakból mit tudunk feltárni az oklevelekben szereplő személynevek segítségével.

Igen nehéz, ha nem lehetetlen például annak eldöntése, hogy az adatok a jegyzők spontán vagy kulturális német-magyar, illetve cseh-magyar kétnyelvűségére utalnak-e. Ennek feltárásához szinte az egyetlen kulcsként tekinthetünk MOLLAY KÁROLY megállapítására, amely szerint különbség fedezhető fel a spontán és a kulturális kétnyelvűség között a német nevek lejegyzésében. A kulturális kétnyelvűségre ugyanis a fonematikus írás jellemző, pl. Adelheid, Klingenbach; ezzel szemben a spontán kétnyelvűség fonetikus lejegyzést eredményez, pl. Olhayt, Chlyngapoh (MOLLAY 1982: 141). Ez utóbbira az általam áttekintett oklevelekben is felbukkant néhány példa: Othonis filij Rugery de Telesprun (1314; AO. 1: 356; vö. Tellesbrunn), Oleyt (1325; AO. 2: 208; vö. ném. Adelheid), Hedreh (1343; AO. 4: 314; ném. Heidrich > m. Héder), Feuldruh (1350; AO. 5: 416; ném. Friedrich), Nicolaus dictus Ha merspach (1416, SoprT. I/2: 116; vö. Hammersbach) stb. Ezek kapcsán azonban véleményem szerint 
felmerül a kérdés, hogy vajon valóban a jegyzők német-magyar kétnyelvűségét (pontosabban: német-magyar-latin háromnyelvűségét) tükrözik-e. Azt sem tartom ugyanis elképzelhetetlennek, hogy a nótáriusok a névhasználók bemondása alapján, német nyelvi kompetencia hiányában írták le a neveket, igyekezve megtalálni a kiejtett hangsornak megfelelő írásképet. E kétség miatt, úgy vélem, a középkori oklevelek adatai alapján az aktuális két- vagy többnyelvűség fajtájának a meghatározása nemigen lehetséges.

\subsubsection{A forrásadottságok}

A fordítási gyakorlat adott nyelven belüli változásának a megfigyelésére e három forráscsoportból leginkább a latin alkalmas, hiszen a latin nyelvű oklevélírás története a 11. század elejére nyúlik vissza Magyarországon, évszázadokon keresztül ez volt a hivatalos írásbeliség tipikus nyelve, és ómagyar kori okleveleink döntő többsége ezen a nyelven íródott. A magyarországi német nyelvű oklevelek első darabjai, mint fentebb láttuk, a 14. század első felében születtek, és elsősorban bajor és osztrák mintákat követtek. A cseh nyelvú írásbeliség szintén külföldi előzményekre vezethetô vissza: KNIEZSA szerint a fennmaradt oklevelek cseh kancelláriai helyesírást követnek, jellemzőbben a morvaországi tartományi kancelláriáét. Ez is azt támasztja alá, hogy a magyarországi cseh nyelvú írásbeliség a cseh városokból hozott írnokok révén alakult ki, csaknem száz évvel a németet követően. A legszúkebb időintervallummal a cseh nyelvú oklevelek esetében számolhatunk, hiszen a legkorábbi is csak 1432-re keltezhető. (Bővebben 1. KNIEZSA 1952: 160-163.)

A vizsgálat során módszertani problémát jelent, hogy a felhasználható oklevelek különféle típusokba sorolhatók. A szűkebben vett birtokügyekkel foglalkozók mellett vannak adóösszeírások is, amelyekben - mint arra korábban felhívtam a figyelmet az előbbiektől némiképp eltérően, az élő névhasználatot jobban tükröző módon jegyezték fel a neveket. E forrásadottságokon azonban nem lehet segíteni, hiszen a 14. század legnagyobb részéből nem rendelkezünk jelentősebb latin nyelvű összeírással, mely világiak nevét tartalmazná, az egyháziak nevét feljegyző pápai tizedjegyzékek pedig ritkán örökítették meg a megkülönböztető névelemeket (vö. SLíz 2011b: 238). A felhasznált német nyelvű források között is van néhány adójegyzék. E sokféleség ellensúlyozására mindössze annyit tehetünk, hogy folyamatosan tekintettel vagyunk az oklevél típusára a vizsgálat során.

A német nyelvű összeírások kapcsán megjegyzendő még, hogy bevezetésük gyakran latin nyelven íródott, a névsor azonban már egyértelmúen német nyelvú. Esetenként már a bevezetésben kódváltás történik, világosan jelezve az összeíró többnyelvűségét; például: „Anno vigesimo quarto der anslag des getraidzehents vnd ist das erst viertail, dederunt" (1424, SoprT. II/2: 314). 


\subsubsection{A fordítás vizsgálatának módszere}

A fordításnak a tulajdonnevek kapcsán a szakirodalomban számos értelmezése él (erre összefoglalóan 1. BÖLCSKEI 2010b: 245-248). A továbbiakban a lehető legtágabb értelmezést veszem alapul, vagyis a név változatlanul hagyásától a más névvel vagy kifejezéssel való helyettesítéséig minden eljárást ide sorolok. A vizsgálat során az összehasonlíthatóság biztosítása érdekében mindhárom nyelv (a latin, a német és a cseh) esetében a VERMES ALBERT PÉTER által kidolgozott modellt alkalmazom (vö. VERMES 2005a, a magyar terminusokra l. VERMES 2005b). Ez négy fokozatot különít el a fordítási eljárásban alkalmazott beavatkozás mértéke szerint: 1. átvitel, azaz változatlanul hagyás; 2 . behelyettesítés, azaz alaki változtatás (pl. m. Farkas $\sim$ lat. Farkasius) vagy célnyelvi megfelelővel való felváltás (pl. m. Lász̧ló lat. Ladislaus); 3. szorosabb értelemben, azaz (megközelítőleg) szó szerint vett fordítás (pl. fr. Richard Caur de Lion $\sim$ ang. Richard the Lionbeart $\sim \mathrm{m}$. Oroszlánsziviü Richárd); 4. modifikáció, vagyis olyan névvel vagy kifejezéssel való helyettesítés, amely nem (vagy csak részlegesen) áll kapcsolatban az eredetivel (pl. m. Károly Róbert $\sim$ ang. Charles I, King of Hungary). Az oklevelekben előforduló személynévi adatokat ezek alapján besorolva világosan összevethetők lesznek a különböző időszakokra, illetve az eltérő nyelvekre jellemző fordítási stratégiák.

A vizsgálathoz olyan neveket veszek alapul, amelyeknek a viselójéről valószínúsíthető, hogy a magyar névváltozatuk volt az elsődleges, vagy legalább létezik magyar nyelvű megnevezésük is. A német és cseh oklevelekből ezek kiválogatása meglehetősen nehéz, hiszen a forrásoknak a latin nyelvűekhez képest aránytalanul kis mennyisége miatt ritkán adódnak olyan esetek, amikor ugyanazt a személyt hol magyar, hol német vagy cseh névváltozattal nevezik meg. Ha ilyen adatok nem állnak rendelkezésünkre, legfeljebb a feltűnően magyaros helyesírásra, a magyar névsorrendre, valamint az egyénnevek jellegzetesen magyar változatára, a családnevek vagy előzményeik magyar eredetére támaszkodhatunk. Ez természetesen jelentősen csökkenti a felhasználható adatok számát.

További probléma, hogy még ha rá is bukkanunk egy megkülönböztető névelemnek vagy családnévnek két különböző nyelvű, szorosabb értelemben vett fordítással született változatára, akkor is nehéz (ha nem lehetetlen) a családtörténet ismerete nélkül eldönteni, hogy melyik nyelvủ változat lehet az eredeti. Ilyen például Erdélyi Jakab soproni polgár esete, akinek neve latin nyelvú oklevelekben mind Erdeli-ként (pl. 1484, SoprT. II/4: 319), mind Subinburger-ként (pl. 1494, SoprT. I/ 6: 138) előfordul. Bár a SoprT. német nyelvű okleveleiben kizárólag a német eredetú változattal találkoztam, MOLLAY (1936: 39) szerint német forrásokban is felbukkan a magyar változat, amiből arra következtet, hogy a név viselője magyar lehetett. Véleményem szerint azonban ennyi adatból sem a névviselő etnikumára, sem anyanyelvére nem következtethetünk, csupán magyar és német névadó közösségre, 
illetve magyar és német névhasználatra gondolhatunk (vö. pl. SZENTGYÖRGYI 2012, SLíz 2013b). Ráadásul az Erdélyi név alapján óhatatlanul felmerül a gondolat, hogy viselője esetleg erdélyi szász származású, magyar-német kétnyelvű személy lehetett. A bizonytalanságot fokozza, hogy ugyanőt latin nyelvű oklevelek Behemként, azaz 'Cseh'-ként is említik (pl. 1488: Jacob Behem; SoprT. II/4: 393), de nem deríthető ki, hogy e megkülönböztetô névelem nyelvhasználatra, származásra, etnikumra vagy valamilyen, a csehekkel való kapcsolatra, hasonlóságra stb. utalhatott-e.

Egy hasonló esetben a megkülönböztetô névelem magyarul, németül és latinul is megjelenik: Michaelem $W$ a zonaros (1458, SoprT. I/4: 245, lat. okl.), Michaelis Wa znas (1463, SoprT. I/5: 79, lat. okl.); Michaelis Lä̈n bether (1465, SoprT. I/5: 155, lat. okl.), Michelen des Le in b a ter (1457, SoprT. II/1: 87, ném. okl.); Michael Linificis (1475, SoprT. I/5: 155, lat. okl.). HÁZI JENŐ e nevek közül a magyart tartotta elsődlegesnek (SoprT. I/5: vii), MOLLAY KÁROLY ezzel szemben úgy vélte, családtörténeti adatokkal nem bizonyítható a névviselő magyar származása, ezért inkább a német változatot tartotta elsődlegesnek (MOLLAY 1936: 20). Véleményem szerint viszont e példa kapcsán sem lehet eldönteni, hogy a magyar vagy a német változat volt-e az elsődleges. Mindenesetre abból, hogy latin nyelvű oklevelekben a név magyar és német változata egyaránt előfordul, arra következtethetünk, hogy (természetesen a latint kivéve) nem írásbeli fordítás történt, hanem mindkét nyelvben élő, valós használatú névváltozatot örökítettek meg a források.

Végezetül azt is meg kell jegyeznem, hogy a várható eredmények jellemzőbben, habár nem kizárólagosan az írásbeli fordítási gyakorlatra lesznek vonatkoztathatók. A latin célnyelvi nevek esetében többnyire nem tudhatjuk biztosan, hogy mi lehetett a forrásnyelv, illetve hogy az élő névhasználatban nem létezett-e több nyelven is megfelelóje a névnek. Abban azonban legalább biztosak lehetünk, hogy fordítás történt, méghozzá jellemzően a feljegyzéskor, nem pedig az élő névhasználatban.

\subsection{A latin célnyelvi névadatok vizsgálata}

\subsubsection{Az egyénnevek fordítása}

A 14. században a latin-görög eredetű egyénnevek beillesztése a latin nyelvú oklevelekbe tipikusan a név latin megfelelőjének használatával, vagyis behelyettesítéssel történt. Kevésbé tipikus az átvitel: mint láttuk, a 14. század folyamán a latin változatoknál jóval kisebb arányban jelentkeznek a vulgáris nyelvű, a mai alapnévtől eltérő változatok (pl. 1357: Petew, AO. 6: 597; 1358: Donch, AO. 7: 129). A legritkábban a mai anyakönyvezhető keresztnévnek megfelelő vulgáris nyelvű változatokkal találkozhatunk (pl. 1351: Moric, AO. 5: 431; 1352: Margith, AO. 5: 573; 1450: Francæ, SoprT. I/3: 280). 
A magyarból vagy más vulgáris nyelvből eredő egyénnevek esetében viszont az átvitel volt az egyik jellemző eljárás (pl. 1336: Gerolth, AO. 3: 250; 1355: Bogizlo, AO. 6: 366; 1358: Kakas, AO. 7: 115), a másik pedig az alaki változtatással, a latin főnévi paradigmába való beillesztéssel történő behelyettesítés (pl. 1329: Berizlaus, AO. 2: 431; 1349: Farcasius, AO. 5: 290; 1355: Luthardus, AO. 6: 262).

A fordítási stratégiák e sokszínűsége a 16. század elejére fokozatosan megszűnt, s az uralkodó eljárás a behelyettesítés lett: a görög-latin eredetű nevek különböző változatai és a magyar eredetû́ nevek a 15. század során egyre ritkábban tűntek fel a forrásokban, majd szinte eltűntek, a gyakoribb idegen eredetú neveknek pedig már a 14. századra kialakult sztenderdizált, többnyire (bár nem kizárólag) latinosított változata vált általános használatúvá (pl. 1439/1447: Stanislaus, FTSznSz. 296, Lelesz a.; 1450 k.: Albertus, FTSznSz. 141, Kont a.; 1524: Oswaldus, VeszprUrb. 24). A ritkább idegen eredetű neveket ugyan továbbra is átvitellel illesztették a szövegbe (pl. 1446: radol, FTSznSz. 295, Gilvács a.; 1450: Hredel, FTSznSz. 297, Tarna a.; vö. még a 18. század eleji összeírások kapcsán N. FODOR 2014: 35), ezek aránya azonban jóval kisebb volt a latin-görög eredetű nevekénél.

\subsubsection{Megkülönböztető névelemek és családnevek fordítása}

A megkülönböztetô névelemes szerkezeteket és a családneveket együttesen vizsgálom a továbbiakban, hiszen a családnevek kialakulása éppen a vizsgált időben zajlott, így a legtöbb esetben nem lehet eldönteni, öröklődött-e már az adott névelem, azaz családnévnek tekinthető-e. A fordítás szempontjából a jelenleg leginkább használatos családnév-tipológiáktól eltérōen (vö. N. FODOR 2008a, CsnVégSz. 9-11) a latinban használt szerkezetek alapján három csoportban érdemes tárgyalni e szerkezeteket: 1. az apa vagy más rokon egyénnevéből eredők, 2. a helynévből eredők, 3. a közszói eredetü többi motivációs-jelentéstani csoport. A nemzetségneves szerkezeteket - a korábban már említett okokból - ismét nem vonom be a vizsgálatba.

A vizsgálat az 1. és 2. csoport esetében két szempontból is elvégezhető: „tulajdonnév a tulajdonnévben" szerkezetük miatt ugyanis ezekben a megkülönböztető névelem vagy családnév alapjául szolgáló tulajdonnevet is fordítani kell, vagyis nem egy, hanem két fordítási műveletet kell végrehajtani. Az Erdélyi (Jakab) például (Jacobus) Transylvanus-ként visszaadva az Erdély helynév szempontjából behelyettesítésnek, az Erdélyi személynév szempontjából viszont szorosabban vett fordításnak tekinthető; a (Jacobus) de Erdel ezzel szemben a helynév szempontjából átvitel, az Erdélyi személynév szempontjából pedig az előzőhöz hasonlóan szorosabban vett fordítás. A továbbiakban az egyénnévi eredetû megkülönböztető névelemek vagy családnevek fordítása kapcsán mindkét szempontot figyelembe veszem, hiszen a vizsgálat célja a személynevek fordításának vizsgálata. A helynévi eredetű személynevek kapcsán azonban csak említés szintjén foglalkozom maguknak a helyneveknek 
a fordításával, mivel azt a személynevekétől eltérő szokások irányíthatták; ezeknek és a jellemző fordítási múveleteknek, stratégiáknak az alaposabb feltárására célzottan a helynevekre, illetve azok különböző fajtáira is tekintettel lévő elemzések világíthatnak rá (1. alább).

\subsubsection{Egyénnévi eredetű megkülönböztető névelemek és családnevek}

Az apa vagy más rokon egyénnevéből eredő megkülönböztető névelemek, illetve családnevek fordítása a 14-15. század folyamán a latin nyelvủ oklevelekben szorosabb értelemben vett fordítással történt: a rokon egyénnevét tipikusan a rokonságot jelölő latin közszóval (pl. filius, gener, nepos) kapcsolták a megnevezett személy egyénnevéhez. Kevésbé tipikusan a rokon nevének birtokos esetbe tett latin változata is előfordult (1354: Nicolao Marsili i, AO. 6: 226; 1478: Stephano V ale ntini, FTSznSz. 292, Kökényesd a.). A 16. század elejére azonban a rokonságot jelölő latin közszavak igen ritkává váltak, az élőnyelvhez közelebb álló összeírásokban, számadáskönyvekben jellemzően már nem is igen fordultak elő. A latin kapcsolóelem eltűnésével párhuzamosan a rokon egyénnevének latin változata helyett a magyar vált használatossá, akár önmagában, akár partonimikumképzővel, pl. 1520: Johannis

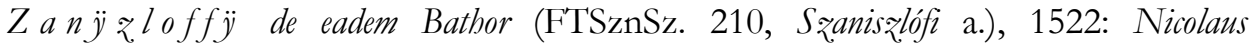
Marthon (SZABÓ 1954: 31, Gare településen); 1524: Lucas Lewryncze (VeszprUrb. 62). Míg tehát e jelentéstani-motivációs kategória fordítása során korábban a szorosabb értelemben vett fordítás volt a jellemző stratégia, addig a 16. század elejére az átvitel, vagyis a változatlanul hagyás vált általánossá.

\subsubsection{Helynévi eredetű megkülönböztető névelemek és családnevek}

A helynévből származó megkülönböztető névelemek, illetve családnevek latinra fordítása hosszú ideig szintén szorosabb értelemben vett fordítással történt: a helynevet általában a latin de prepozícióval kapcsolták az egyénnévhez, pl. *Hagymási helyett Stephano filio Philippi de Hagm as (1357, AO. 6: 568). Ritkábban modifikáció is előfordult: ilyen például a *Pécsi helyett a Nicolao filio Stephani filii Luka de civitate Quinqueecclesiensi (1353, AO. 6: 90). ${ }^{39}$ A 14. században az

${ }^{39}$ Magának a helynévnek a fordítása történhetett például átvitellel (pl. 1358: de Hody, AO. 7: 233). A latin megfelelővel is rendelkező helynevek esetében viszont gyakran behelyettesítéssel éltek, mint azt a Pécs fenti példájában láthattuk. A patrocíniumi eredetủ helyneveket, illetve néhány egyéb típusú nevet, például a korrelációs előtagúakat vagy átvitellel (pl. 1354: Michaelem filium Mauricii de Fels e up re bu l, AO. 6: 230; 1356: Johannes filius 
átvitel még csak kivételként fordul elő (a már említett Dionisius filius Mark Zaadelei [1345, AO. 4: 508]). Valamivel gyakoribb a szorosabban vett fordítás és az átvitel ötvözéseként is felfogható de $+-i$ képzős alak (vö. 3.2.2.2.1. és 5.4.3.2. fejezet).

A filius-szal szemben a de tovább fennmaradt, még a 16. század eleji forrásokban is előfordult, habár a korábbinál jóval ritkábban, és az oklevél típusától függően eltérő mértékben. Az élőnyelvhez legközelebb álló összeírásokból teljesen eltűnt, a számadáskönyvekben is elenyésző mértékben van jelen, a középkori hivatali nyelvet használó, szorosabb értelemben vett birtokügyekben született oklevelekben azonban nem számít ritkaságnak a jelenléte, jellemzően nemesek megjelölésére; mint láttuk, gyakran a helynévi eredetű családnév mellett utalt a nemes valamely birtokára. A 16. század elején tehát még továbbra is használatos volt e névtípus szorosabb értelemben vett fordítása, habár a 15-16. század folyamán a forrástípusok hivatalosságának mértékétől függően előbb az élőnyelvhez közelebbi, majd attól távolabb álló iratokban is fokozatosan átadta a helyét az élónyelvi alak megtartásának, vagyis az átvitelnek (pl. 1446: Anthonius Czegenjy, FTSznSz. 66, Cégényi a.; 1524: Petrus Symegy, VeszpUrb.).

\subsubsection{A közszói eredetű többi motivációs-jelentéstani csoport}

A fenti két típuson kívül a megkülönböztetô névelemek vagy családnevek többi motivációs-jelentéstani kategóriáját a latin fordítások egységesen kezelik: tipikusan a latin dictus-szal szerkesztik a személyjelölő szerkezetbe. Ezt a szerkezetet modifikációnak tekinthetjük, hiszen egy élőnyelvi nevet (pl. Darabos) szintagmával ad vissza: dictus Darabos (1349, AO. 5: 277), azaz 'Darabosnak mondott'. A dictus azonban kevésbé tipikusan már a legkorábbi időktől kezdve el is maradhatott, majd hiánya fokozatosan egyre jellemzőbbé vált, és a 16. század elejére a források minden típusából eltűnt.

A fordítási stratégia változásának vizsgálatakor természetesen azt is figyelembe kell vennünk, hogy a tárgyalt névelemek milyen nyelven emelődtek be a szövegbe. FEHÉRTÓI KATALIN (1969: 48) 14. századi korpusza alapján a leggyakoribb megkülönböztető névelemekről egy táblázatot összeállitva igen változatos eredményt kapott: egyes névelemek magyarul, mások latinul fordultak elő nagyobb arányban a forrásokban. Ebből a szerző a családnévvé válás idejére vonatkozó következtetést

Michaelis de $Z$ e nthmy hal, AO. 4: 439), vagy (részben vagy egészen) szorosabb értelemben véve fordították (pl. 1308: Stephano filio Jule de infe ri o ri Z e le, AO. 1: 167; 1347: Simonem filium Stephani de S a n c to S a lv a to re, AO. 5: 91). (A helynevek fordításáról, a magyar és latin alakok gyakoriságáról - különös tekintettel a patrocíniumi eredetű helynevekre - vö. pl. HOFFMANN 2004; TÓTH 2007; BÖLCSKEI 2010a: 102-103, 223; SZENTGYÖRGYI 2010, 2013.) 
vont le: a latinra fordított elemek még csak a névviselő alkalmi megjelölésére szolgáltak, valódi tulajdonságra utaltak, a magyarul feljegyzettek ezzel szemben már állandósultak (FEHÉRTÓI 1969: 9). Korábban már bemutatott megfigyeléseim szerint (SLíz 2011b: 232) azonban a 14. századra ez a megállapítás még nem vonatkoztatható; egyrészt mert az ugyanazon személyt jelölő megkülönböztető névelem feljegyzésének nyelvében sem figyelhetô meg következetesség, másrészt mert a motivációs-jelentéstani kategóriákat közelebbről szemügyre véve kitűnik, hogy a fordítási stratégiák kategóriánként eltérók. Jól tükrözi ezt a 25. táblázat, melyet saját, összesített korpuszom alapján állítottam össze.

Láthatjuk, hogy a külső-belső tulajdonságot kifejező megkülönböztető névelemek közül csak a leggyakoribbak, a latin szókincs legismertebb rétegébe tartozók jelennek meg többször vagy legalább annyiszor latinul, mint magyarul. Ezzel szemben a néphez, népcsoporthoz való tartozást és a társadalmi helyzetet, méltóságot kifejező névelemeket közel azonos arányban közölték latinul és magyarul. A növényekről, állatokról, tárgyakról, természeti jelenségekről metaforikusan vagy metonimikusan adott neveket viszont szinte sosem fordították (ezekből olyan sokféle szerepel az adatbázisban, hogy nem volt értelme táblázatba foglalni óket).

A 15. század folyamán a latin fordítások aránya minden eddig említett motivációsjelentéstani típusban csökkent, s a 16. századi forrásokban már szinte kizárólag magyar nyelvű megkülönböztető névelemek, illetve inkább már családnevek fordulnak elő (pl. 1515: Nicolaus farkas, FTSznSz. 91, Farkas a.; 1524: Demetrius Ersek, VeszprUrb. 101; 1524: Gregorius Feyer, VeszprUrb. 106; 1524: Stephanus Racz, VeszprUrb. 108). Míg tehát korábban e névelemek esetében mind az átvitel, mind a szorosabban vett fordítás bevett eljárás volt, addig a 16. századra általánossá vált az átvitel.

A foglalkozásra, mesterségre utaló megkülönböztető névelemeket különleges fontosságuk miatt érdemes külön tárgyalni. Ezek feljegyzésének a nyelvével a névkutatás mellett a történettudomány is régóta foglalkozik, hiszen az ipartörténeti kutatások szempontjából alapvető kérdés, hogy a különböző nyelvű foglalkozásmegjelölések közül melyek és hányadik századig utalnak a névviselő által ténylegesen folytatott mesterségekre, azaz melyek és meddig használhatók fel ipartörténeti forrásként (a szakirodalomról összefoglalóan l. GULYÁs 2008; a kérdéshez 1. még N. FODOR 2010: 28-30, SLÍZ 2011b: 231-233). GuLYÁs LÁSZLÓ SZABOLCS (2008: 460-461) a hegyaljai mezôvárosok 15-16. századi tanácstagjainak névadatait egy történetileg és névtanilag egyaránt megalapozott módszerrel vizsgálva arra a következtetésre jutott, hogy még az 1450 utáni néhány évtizedben is nagyjából egyenlő a latinul és a magyarul feljegyzett foglalkozásnévi eredetű megkülönböztető névelemek aránya, és mindkét nyelvú megnevezés utalhat valódi foglalkozásra. A 16. század elejére azonban a magyar nyelvű névelemek már nagy többségükben nem valódi foglalkozást jelöltek, azaz öröklődővé, családnévvé váltak. Ez jelen vizsgálat szempontjából azt jelenti, hogy míg korábban a szorosabb értelemben vett fordítás és az 
átvitel egyaránt jellemző volt a foglalkozásnévi eredetú megkülönböztető névelemek fordítására, addig a 16. század elejére az átvitel vált uralkodóvá.

\begin{tabular}{|c|c|c|c|c|}
\hline \multirow{2}{*}{$\begin{array}{l}\text { Motivációs-jelentéstani } \\
\text { csoport }\end{array}$} & \multicolumn{2}{|l|}{ Magyar } & \multicolumn{2}{|l|}{ Latin } \\
\hline & $\begin{array}{c}\begin{array}{c}\text { Megkülönböztető } \\
\text { névelem }\end{array} \\
\end{array}$ & db & $\begin{array}{c}\begin{array}{c}\text { Megkülönböztető } \\
\text { névelem }\end{array} \\
\end{array}$ & db \\
\hline \multirow{17}{*}{ Külső-belső tulajdonság } & \multirow{2}{*}{ nagy } & \multirow{2}{*}{6} & magnus & 50 \\
\hline & & & esetleg: longus & 3 \\
\hline & veres/vörös & 1 & \multirow{2}{*}{ rufus } & \multirow{2}{*}{35} \\
\hline & piros & 1 & & \\
\hline & fekete & 3 & niger & 14 \\
\hline & \multirow{2}{*}{ kisded } & \multirow{2}{*}{1} & parvus & 9 \\
\hline & & & brevis & 1 \\
\hline & fodor & 12 & crispus & 5 \\
\hline & fehér & 7 & albus & 3 \\
\hline & sqakállas & 3 & barbatus & 3 \\
\hline & sánta & 0 & claudus & 3 \\
\hline & kövér & 1 & \multirow{2}{*}{ ventrosus } & \multirow{2}{*}{1} \\
\hline & kerek. & 3 & & \\
\hline & kopasz & 2 & \multirow{2}{*}{ calvus } & \multirow{2}{*}{1} \\
\hline & tar & 1 & & \\
\hline & vak & 0 & cecus & 1 \\
\hline & orros & 5 & nasutus & 1 \\
\hline \multirow{5}{*}{$\begin{array}{l}\text { Néphez, népcsoporthoz való } \\
\text { tartozás, hasonlóság stb. }\end{array}$} & tót & 9 & sclavus & 7 \\
\hline & besenyő & 4 & bissenus & 3 \\
\hline & német & 6 & teutonicus & 2 \\
\hline & lengyel & 2 & polonus & 1 \\
\hline & francia & 0 & gallicus & 1 \\
\hline \multirow{4}{*}{$\begin{array}{l}\text { Társadalmi helyzet, méltóság, } \\
\text { tisztség stb. }\end{array}$} & kántor (cantur) & 2 & cantor & 4 \\
\hline & tárnok & 2 & tanarnicus & 1 \\
\hline & pap & 2 & clericus & 1 \\
\hline & király & 0 & rex & 1 \\
\hline
\end{tabular}

25. táblázat: Megkülönböztető névelemek magyar és latin változatai 14. századi oklevelekben 
A fentiekben csak magyar nyelvú példákat hoztam fel, de forrásainkban jóval kisebb arányban más vulgáris (leginkább német) nyelvű megkülönböztető névelemek, illetve családnevek is feltűnnek, pl. 1313: Alardi dicti Jung (AO. 1: 302), 1354: Christanus dictus Clainsmit (AO. 6: 226). E nevek szintén bekerülhettek az oklevelekbe latinra fordítva, mint azt az ugyanazon személyre vonatkozó, hol németül, hol latinul feljegyzett adatok bizonyítják. Ilyenek például a következő, 1426-ban feljegyzett névadatok (a latin változatok latin nyelvú oklevélből: SoprT. I/2: 293; a németek német nyelvúből: SoprT. I/2: 299): lat. Johannem Bavarum = ném. Hanns der Bayr von Altenburg; lat. Christannum institorem $=$ ném. Kristan Kramer; lat. Mychaelem pellificem $=$ ném. Michel der Kürsnër. Talán nem véletlen, hogy e példák éppen a néppel való kapcsolatra és a mesterségre utaló motivációs-jelentéstani kategóriákba sorolhatók, hiszen magyar-latin viszonylatban már láttuk, hogy e kategóriák elemei nagyjából azonos arányban jelentek meg magyarul és latinul.

\subsubsection{Latin célnyelvü személynévfordítási stratégiák és változásuk: következtetések}

A latin nyelv kapcsán eddig látottak alapján megállapíthatjuk, hogy a 16. századra mind az egyénnevek, mind a megkülönböztető névelemek, illetve családnevek fordítására alkalmazott stratégiákban nagyfokú egységesülés ment végbe. Az egyénnevek esetében a korábban alkalmazott többféle eljárás helyett ekkorra a behelyettesítés vált uralkodóvá, míg a megkülönböztetô névelemek, illetve családnevek esetében az átvitel, vagyis a változatlanul hagyás, függetlenül a névelem típusától.

Míg az egyénnevek esetében a fordítási stratégia a 16. század elôtt erôsen függött a név eredetétől, addig a megkülönböztetô névelemek, illetve családnevek esetében feltehetőleg más tényezők befolyásolhatták a választást. Az a feltevés, hogy az írnok nem volt kellően birtokában a latinnak ahhoz, hogy le tudja fordítani az adott megkülönböztető névelemet, legfeljebb egyes külső-belső tulajdonságot jelölők esetében állhatja meg a helyét. A begyakorlottabb, a latinnak és a magyarnak egyaránt az alapszókincsébe tartozó névelemek (pl. vörös, fekete, nagy), mint láttuk, gyakrabban elöfordultak latinul. Ezzel szemben komolyabb nyelvtudás szükségeltetik például a fitos lefordításához (pl. 1347: Jacobus dictus Fytus, AO. 5: 106). Egyes esetekben inkább a lefordíthatatlanság állhat az átvitel melletti döntés hátterében, máskor pedig az, hogy a latinban ugyanaz a szó felel meg két, egymással szinonim viszonyban áló magyar szónak (pl. m. vörös és piros - lat. rufus; m. kopasz és tar - lat. calvus). A fordítás ilyen esetekben elfedné a magyarban fennálló különbséget, s a név elveszítené azonosító funkcióját (a helynévi szórványok kapcsán e szempontot hangsúlyozza pl. GYÖRFFY 1970: 200, HOFFMANN 2004: 11). Ahogy azonban a 3.2.2.2.1. fejezetben láthattuk, mégis ismerünk olyan esetet, amikor például a sartor egyszer a szabó, másszor pedig a nyirő̋ helyett áll (vö. FTSznSz. 174, 265, 208). 
A 16. századra bekövetkező egységesülésnek, az egyénnevek esetében a behelyettesítés, a másik névelem esetében pedig az átvitel általánossá válásának a hátterében meglátásom szerint a névrendszerbeli változások állhatnak. A kétféle eljárás 16. századtól következetes alkalmazásának az oka inkább az lehetett, hogy a családnevek a 16. század elejére már jórészt kialakultak, s a fordítást végző írnokok, mint azt már fentebb, a latin és német személyjelölő szerkezetek összehasonlítása kapcsán is jeleztem, érzékelhették az egyénnév és a családnév, valamint a megkülönböztetô névelem és a családnév közötti pragmatikai különbséget. Az egyénnév ugyanis e szempontból listanév, amely többnyire könnyen behelyettesíthető más nyelvi megfelelójével; a megkülönböztetó névelem ezzel szemben kreált név, amely leíró volta miatt jobbára szorosabban véve is fordítható; a családnév viszont átadott név, amely csak változatlanul hagyása esetén tudja betölteni a családdal való kapcsolatot kifejező szerepét (vö. HOFFMANN 2008).

\subsection{A német célnyelvi adatok vizsgálata}

Mint korábban jeleztem, a német és cseh források jóval kisebb számban és rövidebb időszakból állnak rendelkezésünkre, ezért e két nyelv esetében a fordítási stratégiák időbeli változásának a figyelemmel kísérésére nincs lehetőségem.

A 15. századi adatok alapján mindenesetre az rajzolódik ki, hogy a német nyelvú oklevelekben az egyénnevek fordítása többnyire a célnyelvi megfelelő behelyettesítésével: J o rg e $n$ Rozgon 'Rozgonyi György' (1423, SoprT. I/2: 240), T h a m a n von Ciroken 'Ciráki Tamás' (1426, SoprT. I/2: 303), P e tre ins von Briswitz 'Berzeviczi Péter' (1429, SoprT. I/2: 416); ritkábban átvitellel történt: Racz M i c lo s (1432, SoprT. I/3: 42), L a s zlo von Gemeren (1434, SoprT. I/3: 72). Azokat az eseteket, amikor a névváltozat egyértelmúen magyar, a lejegyzés azonban német írásmód vagy kiejtés szerint történik, a korabeli helyesírás szabályozatlansága miatt átvitelként és behelyettesítésként egyaránt lehet értelmezni; pl. Garay J a n u $s$ bs (1428, SoprT. I/2: 369).

Érdemes megjegyezni, hogy ugyanazt az egyénnevet többféle változattal is vissza lehetett adni, így a magyar János megfelelői például: Rosgoni Jo b a n se n (1423, SoprT. I/2: 248) és H anns von der Hayd (1427, SoprT. I/2: 293). Emellett a latin oklevelekhez hasonlóan a németekben sem tapasztalunk következetességet sem helyesírási, sem fordítási szempontból. Jól tükrözi ezt az az 1432-es oklevél, amelyben az említett Racz. Mi c los mellett a Miklós-nak egy másik célnyelvi megfelelóje is feltûnik: Nic lo s von Gara (1432, SoprT. I/3: 42).

A megkülönböztető névelem és a családnév fordítása ennél változatosabb képet mutat. Annak részletes áttekintéséhez, hogy a magyar családnevek motivációs típusait eltérő stratégiával fordították-e, nincsen elegendő példa a német nyelvű oklevelekben. A magyarok nevei között legnagyobb számban előforduló helynévi eredetűek 
esetében mindenesetre azt tapasztaljuk, hogy nagyjából ugyanolyan arányban élhettek az átvitellel - amilyen például a fenti Gewri, illetve a $R$ o s g o $n i$ Johansen (1423,

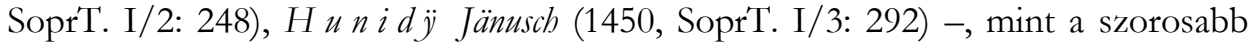
értelemben vett fordítással; pl. a fenti von Ciroken, von Gara mellett ilyen a Jörigen v o n R o z.gon 'Rozgonyi György' (1427, SoprT. I/2: 348), Jorig z w Pö sing 'Bazini György' (1435, SoprT. I/3: 108). Persze azt érdemes hozzátenni, hogy a megkülönböztetô névelem vagy családnév szorosabb értelemben vett fordításakor magát a helynevet vagy behelyettesítéssel - vagyis a település német nevével, annak hiányában pedig a magyar név német nyelvhez igazításával - adták vissza (pl. Bazin $>$ Pösing), vagy pedig a forrásnyelvi név átvitelével (pl. von Gara).

A fenti két stratégia mellett azonban a modifikációra is találhatunk példát a helynévi eredetû típusban: Johannem $C$ b a p o dy (1426, SoprT. I/2: 293, lat.) = Hanns v o n der Hayd (1427, SoprT. I/2: 293, ném.). MOLLAY KÁROLY szerint a magyar névváltozat a Sopron megyei Csapodra, a német pedig a Moson megyei Heidebodenre vezethető vissza (1936: 36, 314). A von der Heide egyébként tipikus lakóhelyre utaló megkülönböztető névelem, illetve abból keletkezett családnév (vö. KOHLHEIM-KOHLHEIM 2005: 31), mely körülbelül annyit tesz, hogy 'hangafüves pusztaság lakója’. A fenti név tehát már önmagában így, a mosoni vidékkel való összekapcsolás nélkül is értelmezhetô, és a német nyelvterület más részein is előfordult; másrészt viszont e vidék német neve szintén a Heide 'hanga, hangafüves terület, puszta' és Boden 'föld' összetételéből keletkezett. Habár THULLNER IsTVÁN szerint a név első adata Bél Mátyástól származik (a névről és a vidékről bővebben 1 . THULLNER 2001: 50), nem elképzelhetetlen, hogy már századokkal korábban is létezett, és MOLLAYnak bizonyára igaza van abban, hogy az említett adatban a név a Moson megyei hangafüves pusztaságra vonatkozott.

Nem lehetetlen, hogy szintén modifikációnak tekinthetô a M o lln e r Estphan név (1428, SoprT. I/2: 375) Molnári Istvánnak, Kelemen győri püspök testvérének a megnevezéseként, amennyiben feltesszük, hogy a helynévi eredetú névelemet a középalnémet Molner 'molnár' foglalkozásnévre cserélte a scriptor (vö. KOHLHEIMKOHLHEIM 2005. Mölder a.). Mivel azonban a soproni bajor nyelvjárás a felnémethez tartozott, és a magyarországi városok külföldről érkező írnokai jellemzően nem a középalnémetet használó észak-német városokból, hanem a felnémet dialektushoz tartozó osztrák és bajor területrôl származtak (vö. MOLLAY 1982: 121), nagyobb a valószínűsége annak, hogy egyszerúen az átvitellel fordított Molnári alak eltorzult változatával van dolgunk.

Apanévi eredetû megkülönböztető névelemre vagy családnévre a magyar etnikumúak megnevezései között mindössze három példát találtam: az $O s t f y$ Janusch (1430, SoprT. I/3: 12) és a $D$ a m u nckusfy a Benedicks (1427, SoprT. I/2: 349) átvitellel, a Herli c b Peter 'Henrik fia Péter' (1420, SoprT. I/2: 176) viszont szorosabb értelemben vett fordítással került az oklevélbe. 
Az egyéb motivációs-jelentéstani kategóriák esetében, amennyiben nem valamely ismert magyar történelmi személyről vagy családról van szó, vagy nincsen két, átvitellel és fordítással visszaadott párhuzamos adat is ugyanarra a személyre, a szorosabb értelemben vett fordítás nem tünik fel, azaz nem lehet eldönteni, hogy német személy német családnevéről vagy magyar személy németre fordított családnevéről van-e szó. Nem véletlen tehát, hogy az említett Wazonaros Leinbater kivételével e kategóriákban csaknem kizárólag átvitellel találkozunk: Gumbusch Niklas (1419, SoprT. I/2: 174), O rzag Mihel (1436, SoprT. I/3: 134), F a r k a s Lasslabs (1440, SoprT. I/3: 193). Ezek a legtöbbször könnyen azonosíthatók, néha azonban az íráskép olyannyira eltorzult, hogy csak egy másik oklevélből származó adat birtokában lehet felismerni a nevet. Így a német nyelvű oklevélben előforduló $S$ c h ü $r \ddot{u} s c h$ Thomann (1440, Sopr'T. I/3: 194) csak egy latin nyelvű oklevél alapján azonosítható: domum Thome filii Johannis S e res dicti (1440, SoprT. I/3: 197). Egy esetben feltehetőleg nem egy átvitellel fordított név elírásával, hanem behelyettesítéssel, vagyis a magyar névnek a némethez való igazításával van dolgunk: S ̈̈kl Niklos 'Székely Miklós' (1428, SoprT. I/2: 374). Ezt támasztja alá a Székely-nek egy másik, latin nyelvű, de helyesírásában egyértelműen német hatást mutató oklevélben előforduló adata is: Andream Z ̈̈kl (1418, SoprT. I/2: 137).

Meg kell még jegyezni, hogy ugyanazon családnevet vagy megkülönböztetô névelemet különböző oklevelekben eltérő stratégiával is fordíthatták, pl. Andre v o n P o g a t t (1415, SoprT. I/2: 101) és B og a ty Andreas (1416, SoprT. I/2: 111); G a r ay Januschs (1428, SoprT. I/2: 369) és Niclos v o n G a r a (1432, SoprT. I/3: 42).

A névelemek külön-külön történő vizsgálata mellett a teljes nevet, így a névsorrendet is érdemes megfigyelni. E szempontból arra a következtetésre juthatunk, hogy a stratégiaválasztást a családnév fordítása határozza meg, és az előzőkben látottakkal szemben ebben viszonylag nagy következetesség tapasztalható. A családnév átvitellel való fordítása esetén ugyanis a magyaros sorrend az uralkodó akkor is, ha az egyénnév nem átvitellel, hanem behelyettesítéssel kerül az oklevélbe (pl. a már látott Farkas Lasslabs, Tott Janken, Rosgoni Johansen stb. esetében); a családnév szorosabb értelemben vett fordításakor viszont többnyire akkor is az indoeurópai sorrendet tapasztaljuk, ha az egyénnév visszaadásakor az átvitelt alkalmazzák (pl. Laszlo von Gemeren, 1434, SoprT. I/3: 72; Andrend von Gürmend, 1435, SoprT. I/3: 101). ${ }^{40}$

\subsection{A cseh célnyelvi adatok vizsgálata}

A cseh nyelvű oklevelekben a latin és a német nyelvűekhez hasonlóan az egyénnevek behelyettesítéssel történő fordítását figyelhetjük meg jellemző eljárásként.

${ }^{40}$ Az eddigi egyetlen kivétel az említett Herlich Peter 'Henrik fia Péter' (1420, Sopr'T. I/2: 176). 
Míg azonban a latinban a behelyettesítés tipikusan a latin-görög eredetú nevek standardizálódott latin változatával történt, addig a németben és különösen a csehben az adott név több német vagy cseh változata is bekerülhetett az oklevelekbe, ahogyan ezt a következő cseh célnyelvi példák is alátámasztják: 'János': Hanus (1459, KNIEZSA 1952: 13), Janem (1460, KNIEZSA 1952: 15); 'László': Ladislawem (1460, KNIEZSA 1952: 15), Waczlaw (1479, KNIEZSA 1952: 30), Llaczek (1479, KNIEZSA 1952: 32), Lačlawom (1480, KNIEZSA 1952: 34). A behelyettesítés mellett a némethez és a latinhoz hasonlóan a csehben is előfordul az átvitel: Janusse (1459, KNIEZSA 1952: 13), Sebestyanem (1460, KNIEZSA 1952: 15), Balassowy (1468-1472 k., KNIEZSA 1952: 22).

A megkülönböztető névelemek és családnevek fordítása e célnyelv esetében is nagyobb változatosságot tükröz. Apanévi eredetúből mindössze egyet találtam: Janem P a n gra c e m (1460, KNIEZSA 1952: 15). Bár egyetlen példából nyilvánvalóan semmiféle következtetést nem lehet levonni, a latin és a német célnyelvi adatok alapján valószínúsíthető, hogy e példához hasonlóan a csehre fordítás máskor is jellemzően átvitellel vagy behelyettesítéssel történhetett e típusban.

Helynévi eredetű megkülönböztető névelem ezzel szemben viszonylag sok van, ezért jól látható, hogy e típust többféle eljárással is fordították. A legjellemzőbb kétségtelenül a szorosabb értelemben vett fordítás volt: pl. Sebestyanem ₹ $\mathrm{R} o$ ₹g a n 'Rozgonyi' (1460, KNIEZsA 1952: 15), Franka Oczkowske bo 'Ocskai' (1467, KNIEZSA 1952: 20), Gregor $S s c z$ a w n ic z k.y 'Selmeci' (1471, KNIEZSA 1952: 23). Mint láthatjuk, a csehben a latinnal szemben több grammatikai megoldást is alkalmaztak a helynévi eredetű megkülönböztető névelem vagy családnév kifejezésére: egyrészt prepozíciót (z Rozgan), másrészt képzôt (Oczkowskeho, Ssczawniczky). ${ }^{41}$ Ezért előfordult, hogy ugyanazt a nevet egyszer prepozícióval: Steffan od $S$ wate bo J a n a 'Szentiványi István' (1470, KNIEZSA 1952: 23), másszor képzéssel fordították: Steffanom a Balassom $S$ we thoge nsky my 'Szentiványi István és Balázs' (1480, KNIEZSA 1952: 34). A szorosabb értelemben vett fordítás mellett elvétve találkozhatunk még átvitellel: Benky 'Benki', valamint behelyettesítéssel is: Erdahata 'Erdőháti' (1459: panossa Erdahata a/Benky Janusse, KNIEZSA 1952: 13).

A többi motivációs-jelentéstani csoportra a német oklevelek kapcsán már említett okból szintén csak néhány, átvitellel fordított példát találtam: $1468-1472 \mathrm{k}$ : Mikulassowi Czuprowy 'Csupor', Magier Balassony 'Magyar' (KNIEZSA 1952: 22); 1472: Lukacz Kardoss (KNIEZSA 1952: 24); 1505: Andreas Chorwath (KNIEZSA 1952: 43).

${ }^{41}$ E két lehetőség a latinban is létezik, a képzést azonban megkülönböztető névelemek fordítására jellemzően nem használták; inkább közszói alaptagú jelzős szerkezetekben találkozhatunk vele, pl. civis Posoniensis 'pozsonyi polgár' (1356, AO. 6: 419), comitatus Gumuriensis 'Gömör vármegye' (1356, AO. 6: 491). 
A névsorrendet tekintve a cseh nyelvű oklevelekben nem figyelhető meg olyan mértékủ következetesség, mint a német nyelvűekben. A családnév szorosabb értelemben vett fordítása esetén ugyan jellemzően az indoeurópai sorrendet követik, az átvitel vagy behelyettesítés esetében azonban mind a magyar, mind az indoeurópai sorrend előfordul. Sőt, mint a fenti Mikulassowi Czuprowy, Magier Balassowy példából látható, akár egy oklevélen belül, egymás után is alkalmazhattak eltérő stratégiákat: a családnév mindkét esetben átvitellel került az oklevélbe; az első egyénnév behelyettesítéssel, a második viszont átvitellel; a névsorrend pedig az első esetben indoeurópai, a másodikban magyar. Összességében azonban úgy tűnik, az indoeurópai sorrend alkalmazása a jellemzôbb megoldás.

\subsection{A különböző célnyelvi adatok összevetéséből adódó következtetések}

A latin, a német és a cseh célnyelvi személynévfordításokat összevetve egyrészt az a meggyőződés alakulhat ki bennünk, hogy az alkalmazott stratégiák igen változatosak voltak, s a köztük való választást olyan nyelvi és nyelven kívüli tényezők irányíthatták, mint a források típusa; a névviselô társadalmi helyzete; a személynév fajtája (listanév, átadott vagy kreált név); a megkülönböztető névelem vagy a családnév adott motivációs-jelentéstani kategóriába való tartozása; a forrás- és célnyelvek közti szó- és névkészletbeli, valamint nyelvtani eltérések; az írnok nyelvismerete; a név azonosító funkciójának megőrzésére irányuló törekvés.

Az átvitel alkalmazása kapcsán például felmerülhet a kérdés, hogy a német és a cseh esetében vajon valóban tudatosan alkalmazott stratégiáról van-e szó, vagy a forrásnyelvi tudás hiányáról, illetve elégtelen voltáról, netán a forrásnyelvben meglévő jelentésnek a célnyelvből hiányzó voltáról, ahogyan az a latin esetében kimutatható volt. A fenti adatok alapján kialakított meggyőződésem szerint sok esetben biztosan nem a tudáshiányból vagy a célnyelvi hiányból fakadhat ez a megoldás, hiszen számos olyan magyar szóval találkozunk az átvitellel fordítottak között, amelyek a magyar és a német, illetve cseh alapszókincsbe tartozván nem jelenthettek gondot még a minimális magyartudással rendelkező scriptoroknak sem (ilyen például a farkas vagy a népnevek: horvát, magyar, rác, székely, tót). Márpedig az nehezen képzelhetô el - különösen a fennmaradt szójegyzékek és nyelvmesterek ismeretében -, hogy Magyarországon múködő írnokok, még ha német többségú városban éltek is, illetve még ha német vagy cseh nyelvterületről érkeztek is a kancelláriára, ne tanultak volna meg legalább alapszinten magyarul. Ráadásul, mint korábban láttuk, az átvitel és a szorosabb értelemben vett fordítás egymás mellett is jól megfért (pl. a Niclos von Gar a mellett a $R$ ac z. Miclos; 1432, SoprT. I/3: 42, ném. okl.); ha pedig egy scriptor a Garai-t képes volt helyesen helynévi eredetû névelemként 
értelmezni, akkor nem különösebben valószínú feltevés, hogy a korabeli magyar alapszókincsbe tartozó Rác-ot nem sikerült lefordítania. Ezért úgy vélem, az átvitel alkalmazása a legtöbb esetben a nyelvtudás mértékétől független, tudatos fordítási stratégiának tekinthető.

Az is kitűnt, hogy a három célnyelvre történő fordítási stratégiák között nagyobb a hasonlóság (pl. az egyénnevek fordítása esetében a behelyettesítés, a helynévi eredetú megkülönböztetô névelemek esetében pedig a szorosabb értelemben vett fordítás uralkodó volta), mint az eltérés. E számos hasonlóság bizonyára nem véletlen: a nyelvi lehetôségek végessége és a nyelvek közötti kapcsolatok mellett minden bizonnyal a közös európai oklevélírási hagyományra, mintára vezethetők vissza. Ugyanakkor egy feltűnő különbség is kirajzolódik a latin és a két vulgáris nyelvú oklevélírás között: míg a latin nyelvú oklevelekben csak igen ritkán fordul elő a magyaros névsorrend - pl. servientem [...] Nogmiklous (1302, AO. 1: 28), 1337: Roazdyak serviens suus (KárOkl. 125), filii Lunagbetri (1349, AO. 7: 102) -, addig a német és cseh nyelvű oklevelekben nagyobb számban találkozhatunk vele, sőt a német esetében bizonyos típusoknál ez a jellemző. Ez az eltérés véleményem szerint a nyelvek korabeli státuszában és használati színterében keresendő: míg a több évszázados hagyományokkal rendelkező latin oklevélírás végig megmaradt a hivatalosság első számú közvetítőjének, addig a német és még inkább a cseh használata szúkebb időszakra és területre korlátozódott. Jellemző például, hogy míg a német városok belső, illetve egymás közötti ügyeinek az intézésében a 14. század végétől egyre nagyobb szerepet kapott a német, addig külső, országos ügyekben e városok továbbra is inkább a latint használták (vö. SOLYMOSI 2006: 165). Emiatt a Magyarországon nagy hagyományokkal nem rendelkező, jellemzőbben „familiárisabb” körben használt német és cseh oklevelekben a latinnál erősebben tükröződhetett az élő névhasználat. 


\section{A SZEMÉLYNEVEKET ÉRINTŐ KONTAKTUSHATÁSOK TIPOLÓGIÁJA}

\subsection{A történeti névkontaktológiai vizsgálatok korlátai}

Az eddigi elemzések során már fel-felbukkantak olyan példák, amelyek a különböző nyelvű és etnikumú népesség együttéléséből következő kontaktusjelenségekként is értelmezhetők. Ezért a következőkben azt járom körül, hogy a középkori oklevelek adatai hogyan és milyen mértékben hasznosíthatók a történeti kontaktológiai vizsgálatok számára.

A névkontaktológiai vizsgálatok az utóbbi időben a magyar személynévkutatásban is egyre nagyobb figyelmet kapnak, habár elsősorban a szinkrón névanyagra irányulnak. Ennek oka egyrészt az, hogy az érdeklődés középpontjában a határon túli területek magyarságának a névállománya, illetve az arra gyakorolt idegen nyelvi hatások feltárása áll. Másrészt módszertani okok is e kutatások mellett szólnak: az élő névanyag alkalmasabb a kontaktológiai vizsgálódásokra, hiszen a névviselőktôl részletes információkhoz lehet jutni azokról a nyelvi, társadalmi-politikai, családi, életmódbeli, szituatív stb. körülményekről, attitűdökről, amelyek a névadást és a névhasználatot befolyásolják, és ugyanazon névviselő többféle névváltozatának, illetve ezek használati színtereinek a megismerését is lehetővé teszik.

A történeti források ezzel szemben nemcsak ezt nem biztosítják, hanem egyéb akadályokat is gördítenek a kutatók útjába. Ezek közül a legnagyobb, hogy míg például a mai határon túli területek magyarsága esetében könnyen felmérhetô, ellenőrizhető a kétnyelvűség ténye, elterjedtsége, egyéni és/vagy közösségi volta, a két nyelv közti dominanciaviszonyok stb., addig - mint azt fentebb kifejtettem (4.3.1. fejezet) - a történeti, különösképpen az ómagyar kori forrásokból korlátozottabban vagy egyáltalán nem deríthető ki a névviselők, névhasználók két- vagy többnyelvúsége. Az ómagyar kori források jellemzően, a középmagyar koriak pedig jelentős részben nem a névviselő saját névhasználatát tükrözik, hanem a feljegyzô által választott névváltozatot. (Persze a névviselő és a feljegyző meg is egyezhet, például a naplók vagy a misszilisek íróinak önmegnevezései esetében.) Ráadásul a névnek csak a feljegyzett változata(i) (illetve a többnevú névviselőnek csak a feljegyzett nevei) áll(nak) rendelkezésre, az egyéb változatok létérôl, használatuk körülményeiről nem áll módunkban tájékozódni. Ez nemcsak azzal jár, hogy az élő névhasználattól eltérő, az adott korbeli viszonyok közt értelmezhetően hivatalos, sztenderd névváltozatok kerülhetnek be a forrásokba, hanem azzal is, hogy a feljegyző nyelvtudása, nyelvjárása is befolyásolhatja a névformát. (Habár kontaktusjelenségeket így is megfigyelhetünk, 
csak tudnunk kell, hogy azok jobbára nem a névadók, névviselők, névhasználók, hanem az írnokok nyelvhasználatát jellemzik.) További probléma, hogy - mint láttuk - a történeti források hivatalos rétegébe tartozó forrástípusok tipikus nyelve hosszú időn keresztül a latin volt, és csak a 14-15. századtól jelentek meg - a latinnál nagyságrendekkel kisebb számban - a vulgáris nyelvűek. Ez gyakran az élőnyelvi névváltozatok latin megfelelőkkel való helyettesítését vagy latinosítását vonta maga után, elfedve ezzel az élő névhasználatban megnyilvánuló interferencia- és kontaktusjelenségeket.

\subsection{A vizsgálat célja, forrásai, módszere}

E nehézségek ellenére az utóbbi időben született néhány írás, amely jelzi, hogy bár korlátozottabb mértékben, de a diakrón személynév-kontaktológiai vizsgálatoknak is lehet létjogosultságuk. Ilyen például N. FODOR JÁNOS két írása, melyekben egy vélhetőleg német anyanyelvú scriptor által készített 16. század eleji összeírás névanyagában, valamint az 1715-ös és 1720-as országos összeírásban tapasztalt interferenciajelenségeket mutatja be (2008b, 2015a), vagy a SZENTGYÖRGYI RUDOLF tanulmányaiban $(2007,2012)$ előkerülő, névhasználatra utaló megfigyelések egy magyar-szlovák kétnyelvű vidéken feljegyzett boszorkányper résztvevőinek nyelvi háttere kapcsán. Egy korábbi írásomban magam azt kívántam bemutatni, hogy felhasználhatók-e - és ha igen, mennyiben - az ómagyar kori oklevelek névadatai a két- vagy többnyelvűség vizsgálatára (SLÍZ 2013b).

A fejezetben a fenti témát továbbgondolva egyrészt azt igyekszem feltárni, hogy az ómagyar kori okleveleket hivatalos voltuk miatt egyáltalán érdemes lehet-e bevonni a történeti névkontaktológiai vizsgálatokba, és ha igen, akkor milyen ómagyar kori kontaktushatásokra és -jelenségekre deríthetünk fényt általuk. Ezek tárgyalása során a tulajdonnevekre VÖRÖS FERENC (2005) által is alkalmazott, majd LANSTYÁK ISTVÁN (2013) által részletesen kidolgozott fogalom- és terminusrendszert követem, elsősorban a névrendszerre, a névkészletre, valamint az élőnyelvi és az írásbeli névhasználat eltéréseire fordítva figyelmet. Ezek tárgyalása során először a nyelvbeli közvetlen, majd közvetett kontaktusjelenségekre, végül a diskurzusbeli kontaktusjelenségekre térek ki.

Forrásként - a fordítási stratégiák vizsgálatához hasonlóan - elsősorban ismét saját, 14. századi összesített korpuszomat, valamint a Sopron szabad királyi város története címú kiadványban (SoprT.) közölt német és latin okleveleket, továbbá a KNIEZSA ISTVÁN által közreadott Középkori cseh oklevelek (1952) címú kötetet használom fel.

Az ómagyar kori kontaktushatások okleveles anyagon való vizsgálata során több nyelv egymásra hatására kell tekintettel lennünk. Ezek közül a legerôteljesebb természetszerúleg a latinnak a magyarra, illetve egyéb vulgáris nyelvekre gyakorolt 
hatása, hiszen a felhasznált források túlnyomó többsége latin nyelvű, és a vulgáris nyelvú oklevélírás kialakulásához is a jóval korábban meginduló latin nyelvú írásbeliség szolgált mintául. Emellett számolnunk kell még a korpuszban a német, a szláv nyelvek, illetve kevésbé hangsúlyosan a vallon és az olasz, valamint a névkészlet szintjén a török hatással. Fontos megjegyeznünk, hogy a többnemzetiségű, többnyelvű országban nemcsak e nyelveknek a magyarra való hatását, hanem a magyarnak ezekre gyakorolt hatását, valamint az említett idegen nyelvek egymásra való hatását is vizsgálnunk kell, ha a források erre lehetőséget nyújtanak.

\subsection{Nyelvbeli kontaktusjelenségek}

A nyelvbeli kontaktusjelenség egykori interferencia, azaz alkalmi kontaktushatás következtében létrejött nyelvi kölcsönzési folyamat eredménye (LANSTYÁK 2013: 44). Ennek két típusa a közvetlen és a közvetett: a közvetlen kontaktushatás következtében az átadó nyelvből hangtestek (morfémák, szavak, esetünkben nevek) kerülnek át az átvevő nyelvbe, míg a közvetett kontaktushatás révén nem kerülnek át átadó nyelvi hangtestek, csak átrendeződnek a kontaktushatásnak kitett átvevő nyelvi hangtestek (LANSTYÁK 2013: 51).

\subsubsection{Nyelvbeli közvetlen kontaktusjelenségek}

\subsubsection{Egyénnevek}

Az ómagyar kori magyarországi egyénnévkészletben számos idegen eredetű név található. Pontosabban: ha a teljes korszak névállományát nézzük, akkor a névkészlet jelentősebb része ilyen. Ezek átvétele nagy valószínűséggel valamilyen fokú kétnyelvűség révén történt.

A névkutatásban ugyan ma evidenciának számít, hogy a közszavakkal ellentétben a tulajdonnevek átvételéhez nem szükséges kétnyelvűség, elég lehet valamilyen kulturális hatás, például a másik nyelvbeli névdivat hatása is; ez azonban inkább napjainkra lehet alkalmazható. Így történik például a filmekben, irodalmi művekben szereplő neveknek vagy a külföldi sztárok nevének az átvétele. Az ős- és ómagyar korra azonban kevésbé alkalmazható ez a feltevés. Elképzelhetetlen például, hogy a messzi német területek névanyaga bármiféle hatással lehetett volna egy felső-Tisza-vidéki magyarra, ha nem lett volna olyan közeg, amely a német névanyagot, névdivatot, névadási szokásokat közvetítette volna. Ahhoz, hogy a német, szláv, vallon, olasz stb. eredetű neveket átvegyék, közvetlen érintkezésre volt szükség. Erre számos területen adottak voltak a lehetőségek, így a többnemzetiségü, a magyar mellett 
jelentős német, vallon és itáliai lakosságú városokban, a szomszédos országokkal érintkezô határvidékeken, az ôshonos és a betelepülő szláv, valamint a betelepülô török, német, vallon, olasz nyelvú népesség által létrehozott, illetve lakott falvakban, a külföldi kereskedőkkel vagy éppen a külföldről érkező szerzetesekkel, papokkal való érintkezésben stb.

Bár nem közvetlen népi érintkezéssel, de még a latin-görög eredetű egyházi nevek átadása is kétnyelvűség révén történt: két-, illetve többnyelvű papok közvetítették őket, akik a tanult latin és a tanult vagy anyanyelvi görög mellett anyanyelvi német vagy valamilyen szláv, illetve úilatin nyelv birtokában is voltak. Ez magyarázza azt is, hogy sok név, illetve névcsoport esetében nem is lehet világosan elkülöníteni az átadó nyelvet: a latin eredetűként számon tartott István hangalakja például német hatást tükröz, a Miklós-é pedig szlávot, nem is beszélve az olyan nevekről, amelyek szláv vagy görög eredete nem dönthetô el, mivel a szlávot közvetítő nyelvként használó bizánci papok vagy az erős bizánci hatás alatt álló területekről (pl. Kijevből) érkező szláv egyházi személyek adták át a magyarságnak. Ezek a nevek viszonylag gyors ütemben elterjedtek Magyarország teljes népességében, melynek jó része bizonyára egynyelvű volt; ekkortól e nevek jelenléte már nem tekinthető élő kontaktusjelenségnek.

Az egyetlen egyénnévcsoport, amelynek átvétele esetleg kétnyelvűség nélkül (is) történhetett az ómagyar korban, az irodalmi eredetú neveké. Ezeket a lovagi kultúra magyarországi virágzása közvetítette egy szúk felső réteg számára. Ugyanakkor még ezek átvételében is szerepet játszott a két- vagy többnyelvűség, hiszen a breton mondakört közvetítő lovagregényeket, valamint a középkori Trója-, illetve Nagy Sándor-regényt az európai királyi, fóúri udvarok között vándorló énekesek, a külföldről érkezô királynék kísérői, a nyugati egyetemeken tanuló papok vagy a nyugatról érkező szerzetesrendek közvetítették; másrészt az irodalmi eredetû nevet viselők egy részének a családja köztudottan külföldi, jellemzően német vagy normann származású volt. (Bővebben, továbbvezető irodalommal l. pl. MOÓR 1937; KOROMPAY 1978, 2008; SLíz 2011b: 162-166).

Az átvett egyénnevek között megkülönböztetünk közvetlen kölcsönneveket (amikor magát a nevet vették át más nyelvből), valamint alaki kölcsönneveket (amikor az alapnév élt az adott nyelvben, csak valamely alakváltozatát vették át más nyelvből).

A latin-görög eredetű egyházi nevek meghonosodását, elterjedését követően alaki kölcsönneveknek tekinthetôk e nevek vulgáris nyelvekből átvett változatai, például a német Hank (János); Kolozs, Niklin (Miklós); a szláv Csépán (István) és Hannus (János); a vallon Gyán (János). Ezek jó része nagy valószínúséggel nem is terjedt el a magyar egynyelvúek körében, ugyanis viszonylag kevés adatuk maradt ránk, és például a Gyán-ra jellemzően a jelentős vallon lakosságú vagy vallonok által is lakott városokból, falvakból vannak adataink. Hasonlóképpen, a Niklin-re (illetve Nikkeul-ra és Nikkel-re) a 14. századi anyagban mindössze a Nagymartoni családból találtam 
példát: Nykul (1351, AO. 5: 536), Nyklynus (1352, AO. 5: 576), Nykkul (1352, AO. 5: 597), Nykulino (1352, AO. 5: 617), Nykel (1354, AO. 6: 268), Nykkel (1358, AO. 7: 126). E család jelentős Sopron megyei birtokokkal rendelkezett, kiterjedt osztrák rokonsága volt vegyesházasságok révén, a két Niklin-ként említett fiú közül (másodunokatestvérek) az egyik a Magyar, a másik pedig a Német megkülönböztetô névelemmel szerepelt, és Magyar Niklin apai nagybátyjának a nevét a német Endurl alakban is ismerjük (vö. ENGEL 2003). Mindezek arra engednek következtetni, hogy a családnak legalábbis egyes tagjai ebben az időszakban talán német-magyar kétnyelvúek lehetettek. A fenti névváltozatok közül a legelterjedtebb a Csépán volt; viszonylag nagy gyakorisága és az adatoknak az egész országra kiterjedő földrajzi megoszlása miatt az Anjou-korra ez már valószínúleg nem tekinthető élő kontaktusjelenségnek.

Az eddig elmondottak mellett meg kell még jegyezni, hogy a névváltozatok csak addig tekinthetők alaki kölcsönneveknek, amíg a névhasználó közösség érzékeli az alapnévvel való összefüggésüket. Amint e kapcsolat tudata elhomályosul, e neveket közvetlen kölcsönneveknek kell nyilvánítanunk. Az alapnév és a névváltozat kapcsolatának a lazulására több esetet is felhozhatunk példaként (vö. FEJÉRPATAKY 1918, KOROMPAY 1980: 520, SLíz 2011b: 50-56). Ezek a szakirodalmak jórészt alapnevek keveredését, illetve a magyarban keletkezett változatokkal való kapcsolatukat mutatják be, kevesebb figyelmet fordítva az idegen eredetű névváltozat és az alapnév kapcsolatának a lazulására. Ennek az oka persze elsősorban az, hogy e kapcsolat jellegének a megváltozását igen nehéz adatokkal is alátámasztani. A fentebb közölt Nyklynus-ból és az alább bemutatandó adatból is legfeljebb csak sejthető, hogy a latin Nicolaus-nak a német eredetű Nikkel-lel (hasonlóképpen pedig a latin Johannes-nek a vallon eredetû Gyán-nal) való összefüggése már nem feltétlenül volt nyilvánvaló a scriptor számára. Erre utal legalábbis az, hogy a névváltozatok esetében tipikusan alkalmazott két fordítói stratégia, a latin alapnévvel való behelyettesítés (Nicolaus, Johannes), illetve az élónyelvi alak változatlan átvitele (Nykekel, illetve Niklin, Gyan) helyett a német, illetve vallon eredetú élőnyelvi változat latinosított alakja került az oklevélbe: Nyklynus; illetve Gibaninus (1323, AO. 2: 103). Ezt az eljárást ugyanis a latinra fordítás során a fenti példával ellentétben inkább akkor követték, amikor a vulgáris nyelvű névnek nem volt latin nyelvű megfelelöje, pl. Draganus (1315, AO. 1: 386), Farkasius (1339, AO. 3: 567), Renoldus (1343, AO. 4: 327).

\subsubsection{Megkülönböztető névelemek és családnevek}

A kétnyelvű környezetben magyarok megnevezésére használt idegen eredetű megkülönböztető névelemek szintén lehetnek közvetlen kölcsönnevek. A szinkrón ragadványnév-kutatások eredményei alapján tudjuk, hogy bár a ragadványnevek általában a domináns nemzetiség nyelvén keletkeznek, a kevésbé domináns nyelv(ek) is 
forrásukul szolgálhatnak (vö. pl. BAUKO 2013: 74-75 és passim). Ez a megállapítás a megkülönböztető névelemekre is érvényesíthető, hiszen ezek azonos módon való létrejöttük okán gyakorlatilag történeti ragadványneveknek tekinthetők. Ugyanakkor az idegen nyelvból közvetlenül átvett közszóból vagy a magyarban nem használt idegen szóból a magyarok által létrehozott ragadványnevek nem tekinthetők kölcsönneveknek, hiszen nem a tulajdonnevet vette át a beszélőközösség egy másik nyelvből, csupán az alapjául szolgáló közszót (vö. JANITSEK 1997: 107, LANSTYÁK 2013: 54). Ebből következőleg annak eldöntéséhez, hogy egy ragadványnév kölcsönnév-e vagy sem, ismernünk kell keletkezésének a körülményeit. Csakhogy ezeknek a felderítése még a szinkrón ragadványnév-kutatásokban sem mindig könnyú, illetve lehetséges, a történeti vizsgálatokban viszont szinte lehetetlen. Ennélfogva nem tudhatjuk, hogy például a Petri dicti Abeyduch (1327, KárOkl. 65) adatban az Abajdóc kölcsönnévnek számít-e, hiszen számos tényező homályban marad előttünk: nem tudjuk, hogy a ma nyelvjárási szinten élő abajdóc a névkeletkezés idején már használatos volt-e kölcsönszóként a magyar valamely nyelvjárásában (a TESz. első adata éppen az említett személyre vonatkozik); hogy milyen (és hány) nyelvű volt a névviselő, valamint a névadó közösség; és legfőképpen hogy az Abajoóc-ot a másik nyelvben keletkezett névként vették-e át a magyar névhasználók, vagy maguk hozták létre a megfelelő közszóból.

Könnyebb a dolgunk a Nicolaus dictus Helmes (1329, AO. 2: 441) adat esetében, hiszen a magyar -s képzó jelenléte egyértelmú bizonyíték arra, hogy a német eredetű helm 'sisak' ekkora már élt a magyar nyelvben. Már a melléknév képzése is magyar nyelvi eszközzel történt, ezért biztosak lehetünk benne, hogy a név is a magyarban keletkezett, tehát bizonyosan nem kölcsönnévvel van dolgunk.

A családnevek kapcsán elvileg kevesebb nehézség merülhetne fel, hiszen azok az idegen eredetű családnevek, amelyeket magyarok is viseltek többnyelvű vidékeken, de az össznépességben nem voltak elterjedtek, közvetlen kölcsönneveknek számíthatnak (vö. LANSTYÁK 2013: 52). Ennek vizsgálatához azonban egy-egy többnyelvú területnek, például egy-egy olyan, jól dokumentált történelmú városnak az okleveles forrásait kell alaposan feldolgozni, mint amilyen Sopron vagy Esztergom, a névadatokat névviselókhöz kötve, részletes családtörténeti kutatásokkal megtámogatva. Csak így lehetne ugyanis (ha egyáltalán lehetne) fényt deríteni az adott család etnikumára és nyelvhasználatára, valamint arra, hogy a vizsgált névelem öröklődő volt-e (hiszen csak ebben az esetben számít családnévnek).

\subsubsection{Nyelvbeli közvetett kontaktusjelenségek}

Nyelvbeli közvetett kontaktushatás következményének is tekinthetjük a személynévrendszerben az ómagyar korban részben idegen nyelvi hatásra bekövetkező változásokat. Az egyik jelentôs változás az egyénnévkészlet összetételének az átalakulása: 
míg az ómagyar kor elején az egyénnévállomány jelentősebb hányada (a magyar eredetű nevek többsége) feltehetőleg leíró név volt, ${ }^{42}$ kisebb része pedig más nyelvekből átvett referáló név, addig az ómagyar kor végére a leíró egyénnevek szinte teljesen átadták a helyüket a referálóknak. (Természetesen mire ez a változás lejátszódott, az átvett egyénnevek többsége már nem volt élő kontaktusjelenségnek tekinthetô, de a változást kétségkívül a korábban bemutatott latin és vulgáris nyelvi kontaktushatások indították el.)

A másik nagy változás a személynévrendszer szerkezeti átalakulása volt: a korszak végére az egyelemú névadás helyett a többelemú vált jellemzővé, s az ekkorra már többnyire referáló egyénnevek rendszere mellé kialakult a nexusnevek (a családnevek) rendszere. Ez persze csak részben tekinthetô más nyelvek hatásának, de tagadhatatlan, hogy a családnevek kialakulásának okai között a többnyelvű papság és a nyugatról bevándorló, már családnévvel rendelkező népesség által közvetített idegen nyelvi minták nem elhanyagolható szerepet töltöttek be (vö. pl. MIKESY 1959, HAJDÚ 2003: 735, FARKAS 2009b: 28, N. FODOR 2010: 19, SLíz 2011b: 176, TÓTH 2014a: 182). Ez utóbbira jó például szolgálnak a Károly Róberttel Nápolyból érkező, francia származású Drugethek: míg ugyanis a 14. század elején a megkülönböztetô névelemek feljegyzése, kombinálása és szerkesztése még rendkívüli változatosságot mutat a forrásokban, addig e család tagjainak megnevezéséből sosem hiányzik a francia nyelvterületről hozott Drugeth névelem, amely ebből (is) kikövetkeztethetőleg már bizonyára öröklődött, azaz családnév lehetett (vö. SLíz 2011b: 213). A hamarosan nagy birtokokra és hatalomra szert tevő, az országban végleg letelepedő család gyorsan kétnyelvűvé válhatott és elmagyarosodott; ekkortól a családnévvel még nem rendelkező többségben idegen eredetú családnevük kontaktusjelenségnek fogható fel.

Míg a családnevek kialakulása részben kontaktushatásra történt, a magyar névsorrend kialakulását nem befolyásolta a más nyelvekkel való érintkezés, hiszen az ómagyar korból származó, kételemű személynevet tartalmazó helynévi és szórványosan magyar alakban és sorrendben felbukkanó személynévi adatokból is kiviláglik, hogy az élőnyelvben kezdettől fogva a magyaros névsorrend volt a jellemző (pl. 1337: Roazdyak, KárOkl. 125; 1354: Filkeiakaphaza, AO. 6: 169). Ezt különösen a rokon népek idegen nyelvi mintára kialakult indoeurópai sorrendú személynévhasználatával összevetve érdemes kiemelni (bővebben, továbbvezető magyar és külföldi irodalommal l. FARKAS 2009b: 28-29).

Pragmatikai szempontból nyelvbeli közvetett kontaktusjelenségnek tekinthetjük az ún. kétnevűséget, vagyis azt a - többnyelvú közösségekben nem ritka - jelenséget,

${ }^{42}$ Habár ezek között is bizonyára voltak olyanok, amelyeket nem a személy valamely sajátosságának a jelzéseként, hanem a hagyományozódó névkészletből való választás révén, azaz referáló névként adtak (vö. pl. TóTH 2013: 242). 
amikor egy személy nevének több nyelven is létezik megfelelője, s a névviselő a beszédhelyzet, a nyelvhasználati színtér, az adott beszélőközösség, beszédpartner stb. nyelvéhez alkalmazkodva váltogatja ezeket. Az ómagyar korból ilyen például a magyar és német megkülönböztetô névelemmel vagy családnévvel is feltûnó, korábban már említett soproni polgár esete: Jacob E r de li (1484, SoprT. II/4: 319, lat. okl.), Jacob S i benpürger (1495, SoprT. II/1: 252, ném. okl.).

\subsection{Diskurzusbeli kontaktusjelenségek}

Diskurzusbeli kontaktusjelenségnek az átadó nyelv alkalmi kontaktushatása révén az átvevő nyelvi diskurzusokban megjelenő nyelvi elemeket vagy formákat nevezzük (vö. LANSTYÁK 2013: 44). Ezek alkalmiságuk miatt jóval könnyebben megragadhatók a történeti források alapján, mint a nyelvbeli kontaktusjelenségek. Az előzőkben ugyanis a legtöbb problémát az okozta, hogy többnyire nem ismerjük a névviselő, illetve a névadó, névhasználó közösség nyelvi és etnikai hátterét. Ezzel szemben a diskurzusbeli kontaktusjelenségek vizsgálata jellemzően az írott alakra irányul; annak feljegyzőjérôl pedig ha mást nem is, azt biztosan tudjuk, hogy legalábbis kétnyelvú volt: egy (vagy több) vulgáris (anya)nyelvéhez egy tanult latin nyelv társult. A következőkben a helyesírásban, valamint a hangtan, a morfológia és a szintaxis szintjén jelentkező diskurzusbeli kontaktusjelenségek bemutatása során azonban (az előzőktől eltérően itt most nem lévén tekintettel a személynevek fajtájára) látható lesz, hogy az adatok sokszor még annak a valószínúsítését is lehetővé teszik, hogy mi lehetett a szóban forgó vulgáris nyelv.

\subsubsection{Helyesírás}

Egy latin nyelvű oklevélben a következő egyénnévvel találkozhatunk: Zaccio (1350, AO. 5: 402). A cci betűkapcsolat a / $\mathrm{t} /$ jelölésére az ómagyar kori magyarban egyáltalán nem megszokott; hogy itt valóban erre szolgál, azt az oklevél külsején már chy betúkapcsolattal megismételt egyénnév bizonyítja: Zachyou. Mindezek alapján véleményem szerint méltán gyanakodhatunk olasz kontaktushatásra, a nevet feljegyző scriptor olasznyelvűségére.

Több példát is találhatunk német kontaktusjelenségekre latin nyelvủ okleveleinkben. Ilyen például a /ts/ fonémát jelölő č. (pl. 1323: Henczone, AO. 2: 74; 1325: Pongraczy, AO. 2: 223; 1326: Packucz, AO. 2: 239; 1352: Kunczlini, AO: 5: 563), illetve a /J/ fonémát jelölő sch betűkapcsolat (pl. 1354: Schtephanus, AO. 6: 244; 1421: Sebastianus de Scholagi, SoprT. I/2: 206; 1440: Michaeli de Hodosch, SoprT. I/3: 201).

Elvétve magyar kontaktushatást is felfedezhetünk a soproni német nyelvú oklevelekben. A magyar kancelláriai helyesírást követi például a következő adat: Gewri 
Balaschen (1493, SoprT. II/1: 241). Az efféle adatokat feljegyző scriptorokról gyanítható, hogy magyar-német-latin háromnyelvűek lehettek. Azt azonban már nemigen lehetne megmondani, hogy az egyértelmúen tanult latin mellett a magyar és a német spontán elsajátított vagy tanult nyelv lehetett-e, hiszen a magyar-német vegyes etnikumú városban mindkét nyelv esetében mindkét lehetőség ugyanolyan valószínúséggel esik latba.

\subsubsection{Hangtan}

Az előzőkben látott adatok némelyike hangtani szinten is kontaktushatást tükröz. Jellegzetesen német hatásra utaló kontaktusjelenség például a zöngétlenítés, amelyet a német nyelvű oklevélbe magyar alakjukban átvitt Estphan és Balaschen egyénneveken is megfigyelhetünk. További példák személyjelölő szerkezetekből: Andre von Pogatt 'Bogáti András' (1415, SoprT. I/2: 101, ném. okl.), Sebastianus de Sollyak 'Sólyagi Sebestyén' (1422, SoprT. I/2: 227), Francz de Cheprek 'Csepregi Ferenc' (1450, SoprT. I/3: 280, lat. okl.). Hasonlóval találkozott N. FODOR JÁNOS egy 1500-1520 között keletkezett szabolcsi összeírásban: temeter 'Demeter' (N. FODOR 2008b: 254-255).

A soproni középbajor nyelvjárás nyomait fedezhetjük fel a következő adatokban: Johanni Wubek de Pelsuikech (tkp. Bebek; 1418, SoprT. I/2: 137, lat. okl.; ugyanitt: Wudensem a Budensem alak helyett), Demetrius, dictus Horbat (tkp. Horvát; 1437, SoprT. I/3: 137, lat. okl.). Ezeknél is különlegesebb a következő: magnifici viri Ladislai filius Baybadi (1421, SoprT. I/2: 206). Ebben a latin személyjelölő szerkezetben a voyvoda genitivusi alakja fedezhetô fel; a megjelölés Héder nb. Tamási László ajtónállómesterre vonatkozik, akinek apja erdélyi vajda volt. ${ }^{43}$ A jelenség magyarázata, hogy a bajor nyelvjárások lejegyzésében ekkoriban a $b$-t és a $w$-t egyaránt használták a /b/ és /v/ lejegyzésére, bár a 13. század végétől szókezdő pozícióban a $w$ egyre gyakoribbá vált, és már a szó belsejében és végén is előfordult (TAUBER 1993: 138-139)..44 A $b$-s lejegyzésre egy német oklevélben például a következóket találhatjuk: Baczlab van der Duba (tkp. Waclaw), Baldburg (tkp. Waldpurga) (1422, SoprT. I/2: 218). A fentebbi

${ }^{43} \mathrm{Az}$ adat érdekessége nemcsak a latintól eltérő írásmódban rejlik, hanem abban is, hogy a megkülönböztető névelem pozíciójába az apa egyénnéve helyett (János) a puszta méltósága került. A méltóságnevek (voyvoda, banus stb.) ugyanis önmagukban nem, csupán egyénnévvel együtt, vagy legalább pontosító, jelzős szerkezetben (pl. voyvoda Transsilvanus) szoktak előfordulni. Ezt a szokatlan megoldást magyarázhatná persze, ha tudomásunk lenne arról, hogy az apát *Vajda-ként is említették, erre azonban ENGEL genealógiájában (2003) nincs adat.

${ }^{44}$ Ezúton is köszönöm Müller Mártának a jelenség magyarázatában nyújtott önzetlen segítségét. 
adatokban tehát a középbajor nyelvjárási írásmódnak a magyar nevek latin nyelvú lejegyzésébe való beszűrődését fedezhetjük fel.

Mivel az említett egyénnevek mellett álló megkülönböztető névelemek vagy családnevek magyar eredetűek, feltételezhetjük, hogy a névviselők magyar etnikumúak voltak, a scriptorokat illetôleg pedig eddig látott háromnyelvűségük mellett talán már az is megkockáztatható, hogy a német és a magyar közül a német lehetett a dominánsabb nyelvük.

\subsubsection{Morfológia és szintaxis}

\subsubsection{Névsorrend}

A latin, német és cseh nyelvú oklevelekbe a magyar nevek, mint korábban láttuk, tipikusan nem a magyar, hanem az indoeurópai névvsorrendben kerültek be, habár az utóbbi két nyelvben ettôl eltérő, a magyar sorrendet megőrző fordítási stratégiát is tapasztalhatunk. Amennyiben magyar személyekről van szó, a nevük magyaros sorrendje nem feltétlenül tekinthetô kontaktusjelenségnek, sokkal inkább tudatos fordítói stratégiának, átvitel eredményének. Ha azonban vélhetôleg nem magyar etnikumú személyek neve jelenik meg magyaros sorrendben, az már kétségkívül kontaktusjelenség: Chürcz Steffan (1409; SoprT. I/2: 21; német okl.), Putten Leonart (1430; SoprT. I/3: 9; német okl.), Glacz Peter, Stober Mertt, Schon Peter (1435; SoprT. II/3: 35; latin dézsmajegyzék németül, többségükben indoeurópai sorrendben feljegyzett nevekkel).

\subsubsection{Szintaktikai szerkezetek}

A latin szövegben ritkán megjelenő, az élő nyelvhasználatra utaló toldalékok, illetve a magyar és a latin grammatikai kapcsolóelemek, szerkezetek együttes alkalmazása a teljes személyjelölő szerkezetekben fordítástudományi szempontból kevésbé tipikus fordítói eljárásként értékelhető (vö. pl. a helynevek kapcsán SZENTGYÖRGYI 2010). Kontaktológiai szempontból viszont diskurzusbeli kontaktusjelenségként is értékelhető, hiszen a legalább kétnyelvű scriptor (anya)nyelvének a latin nyelvhasználatára gyakorolt alkalmi kontaktushatását jelezheti. Hogy az efféle szerkezetek alkalmazása mennyire volt tudatos vagy ösztönös, azt utólag már lehetetlen megállapítani. Ráadásul az alább bemutatandó esetek kétféleképpen is értékelhetôk. Egyrészt feltételezhetjük, hogy a nevek feljegyzői beszéltek a latin szerkezetekre hatást gyakorló nyelveken, hiszen így tudott az adott vulgáris nyelv hatást gyakorolni a latin nyelvhasználatukra. De ennek az ellentéte is elképzelhető: éppen azért alkottak ilyen hibrid szerkezeteket, mert nem ismerték az adott vulgáris nyelvet, 
nem ismerték fel a magyar, német, szláv alakok grammatikai jelöltségét, ezért úgy illesztették őket a latin szerkezetekbe, mintha jelöletlenek volnának. Ez utóbbi esetben az alábbi adatokban természetesen tévedés lenne kontaktusjelenséget feltételeznünk. Mint látjuk, e példák értékelésére három magyarázat is kínálkozik: 1. tudatos, de atipikus fordítói megoldás, 2. a vulgáris nyelv öntudatlan hatása a latin nyelvhasználatra, azaz diskurzusbeli kontaktusjelenség, 3. a vulgáris nyelv nem ismeréséből adódó tévedés. Mivel azonban az alábbi példák némelyike alapján arra következtethetünk, hogy a scriptor ismerte az adott vulgáris nyelvet, a 3. lehetőséget kevésbé tartom valószínűnek, az esetek kis száma pedig némileg csökkenti az 1. lehetőség esélyét. Ha e kérdésben nem is tudunk dönteni, az mindenesetre kimondható, hogy hasonló esetek mind magyar-latin, mind német-latin és szláv-latin viszonylatban előfordulnak, de arányuk mindegyik nyelvpár esetében elenyésző az általános gyakorlatnak megfelelő szerkezetekéhez képest.

A magyar toldalékok és szerkezetek latin szerkezetekkel együtt való alkalmazásának egyik esete az apanévi eredetű megkülönböztető névelemes szerkezet kétnyelvú jelölése: Johannis filii Balasee (1355, AO. 6: 333). Hasonlóval a helynévi eredetû megkülönböztetô névelemes szerkezetek között is találkozhatunk: Nicolao filio Andree nigri dicti de Turucy (1344, AO. 4: 391), Emerico de Kyurthy (1344, AO. 4: 397). Az efféle esetekből - bár csak elszórtan - többet is lehet találni. Ezzel szemben a 14. századi korpuszomban eddig mindössze egyetlen, már említett példát találtam arra, hogy bár a személyjelölő szerkezet latin mintát követ (egyénnév + filius + apa egyénneve), addig az ehhez még hozzákapcsolt helynévi eredetű megkülönböztető névelem nem latin szerkezettel (de + helynév), hanem élőnyelvi alakjában, dictus nélkül jelenik meg; igaz, a tipikus latin névsorrend által megkívánt pozícióban, a szerkezet végén: Dionisius filius Mark Zaadelei (1345, AO. 4: 508). A magyar névalak latin szerkezetbeli helyzete egyértelmúen arra mutat, hogy a név feljegyzője tisztában volt a Szádeleji helynévi eredetú voltával, azaz (valamilyen szinten legalábbis) tudhatott magyarul.

A helyneves szerkezet német-latin kétnyelvű jelölése figyelhető meg a következő személyjelölő szerkezeteken: Oth de Telyesprunnar (1354, AO. 6: 201), Hons de Altemburger (1390, SoprT. I/1: 234). Latin személyjelölő szerkezetbe illesztett, élő német nyelvhasználatot tükröző helynévi eredetú megkülönböztető névelemre is akad több adat, pl. Nicolaus filius Seydlini Mogurdorpher (1355, AO. 6: 270). Ez a Szádeleji kapcsán már látott eset „német változata”: ebből is nyilvánvaló, hogy a scriptor tisztában volt a Mogurdorpher helynévi eredetével. Más esetekben ezzel szemben érdekes ellentmondást tapasztalhatunk: a helynévi eredetú német megkülönböztető névelem vagy családnév nem de-vel vagy anélkül, hanem dictus-szal kapcsolódik az egyénnévhez: Petrus dictus Offner (1388, SoprT. I/1: 217), Petrus dictus Ophnar (1388, SoprT. I/1: 220). E névelem eredetét egy német nyelvű oklevél adata teszi kétségtelenné: Peter von Ofen (1379, SoprT. I/1: 180). Ebben az esetben feltételezhetjük, hogy a latin nyelvű oklevélbe azért dictus-szal került be a 
névelem, mert az írnok nem ismerte Buda német Ofen nevét, habár ez a korban elég nehezen elképzelhető. További lehetőségként felvethető még, hogy az Ofen nevet ugyan ismerte, de nem ébredt rá, hogy az Offner-ben ez keresendő. Hogy ez az eshetőség mennyire nem lehetetlen, azt két további adat is alátámasztani látszik. Ezekben szinte a felismerhetetlenségig eltorzult a megkülönböztető névelem: Thome dicti Tomohar (1411, SoprT. I/2: 38, lat. okl.), illetve inter Thomam et Nicolaum Sandarfar (később: Sanderfar; 1430, SoprT. I/3: 1, lat. okl.). E neveket csak más latin és német nyelvű oklevelek alapján lehet „megfejteni”: Thoma Turenhofer (1399, SoprT. I/1: 262, lat. okl.), Thoman Thurnhofer (1410, SoprT. I/2: 29, ném. okl.) Turnhof bajor település nevéből; illetve Nicolaus filius Mathie de Sadendorff (1430, SoprT. I/3: 6) és Taman von Schaddendorff (1431, SoprT. I/3: 31) a Sopron megyei Somfalva német Schattendorf Schadendorf nevéből. Ezek alapján feltételezhetjük, hogy a romlott alakok a név felismerésének hiányából fakadnak, az pedig a kellő szintű nyelvismeret hiányából adódhat. Ugyanakkor azonban azt sem zárhatjuk ki, hogy az Offner esetében nem erról volt szó, hanem arról, hogy a scriptor a dictus-szal kívánta visszaadni az élónyelvi névhasználatot, ahogyan az a magyar helynévi eredetú megkülönböztető névelemek kapcsán is előfordult szórványosan (vö. pl. 1353: Johannes dictus Geurii, AO. 6: 71; 1356: Michaelis dicti Dobazy, AO. 6: 452).

Kettős jelölés német nyelvű oklevelekben, német-magyar viszonylatban is felfedezhető: Briccius von Ewry (1449, SoprT. I/3: 278), Michael von Wathay (1452, SoprT. I/3: 356) stb.

Magyar személy apanévi eredetű megkülönböztető névelemének német nyelvú megjelölésére latin oklevélben eddig az egyetlen példaként a következőt találtam: Petrus Herlich (1421, SoprT. I/2: 190). E név viselóje Berzeviczy Péter tárnokmester, akit egy korábbi, német nyelvű oklevélben a fordítás kapcsán már látott Herlich Peter (1420, SoprT. I/2: 176) alakban neveztek meg. Egyéb latin nyelvú oklevelekben kétféle latin szerkezettel visszaadva is találkozunk a névvel: Petri filii Herrici (1419, SoprT. I/2: 167) és Petri Herrici (1419, SoprT. I/2: 170).

Szláv-latin viszonylatban eddig mindössze egyetlen esettel találkoztam. Ebben az apanévi eredetû megkülönböztető névelemet adja vissza a scriptor két- vagy háromnyelvú jelöléssel: Salamone filio Wlkowy (1356, AO. 6: 498). Az -ov egyértelmúen déli szláv patronimikumképző (az adat Kőrös megyéhez köthető), az -i viszont latin genitivusi végződés vagy akár magyar patronimikumképző is lehet.

\subsection{Az elemzés tanulságai}

A nyelvbeli és diskurzusbeli kontaktusjelenségeknek (vagy az esetleg azokra utaló adatoknak) a bemutatása során felmerülő problémák, megoldhatatlan kérdések jól tükrözik azokat a nehézségeket, amelyek a történeti névkontaktológia múvelését a szinkrón vizsgálatoknál nehezebbé, bizonytalanabbá teszik. A számtalan fennmaradt 
adatnak csupán a töredéke használható fel ilyen célú kutatásokra, hiszen már a névadók, névviselők, illetve névhasználók két- vagy többnyelvűségének a bizonyítása is nehézségekbe ütközik. Az továbbra is egyértelmú, hogy a történeti névkontaktológiai vizsgálatok számára az ómagyar kori oklevelek nyújthatják a legkevesebb tanulságot; megbízhatóbb és nagyobb mennyiségú adatokat inkább a kevésbé hivatalos, az élő nyelv- és névhasználathoz közelebb álló forrástípusokból szerezhetünk. Ilyenek azonban nagyobb mennyiségben csak a középmagyar kortól maradtak ránk; ez pedig azt jelenti, hogy a rendszeresebben folytatható, átfogó jellegú történeti névkontaktológiai kutatások legkorábbi kényszerű kezdő időhatára Magyarországon a 16. század. Az ennél régebbre visszanyúló vizsgálatok is hozhatnak ugyan részeredményeket, mint láthattuk, de a kutatás ezek értékéhez és mennyiségéhez képest aránytalanul nagy energia- és időbefektetést, részletekbe menő nyelvészeti és történettudományi munkálatokat igényelne, és még a legnagyobb erőfeszítések ellenére is túlságosan ki van téve az esetlegességnek, a véletlen hatalmának. 



\section{A VIZSGÁLATOK EREDMÉNYE ÉS HASZNOSÍTHATÓSÁGA}

Az Anjoukori okmánytár kiadott köteteinek immár teljes körú feldolgozása, a névadatok eredetének meghatározása, a névviselők társadalmi réteghez és területhez kötése jelentős mértékben, több mint 6600 rekorddal növelte a 13-14. századból rendelkezésünkre álló egyénnevek és személyjelölő szerkezetek számát. Ezen adatok névtári feldolgozása újabb, több ezres nagyságrendú adatbázissal gazdagítja egyrészt a magyar személynévkutatást, másrészt az adatok jövőbeli feltöltése révén a Dictionary of Medieval Names from European Sources (DMNES) címú online névtárat is (vö. http://dmnes.org/). Ennek a közös európai középkori névkincset tartalmazó hatalmas névtárnak a folyamatos építése több szempontból is nagy hatással lehet a magyar névkutatásra. Egyrészt mert számos, eddig megfejtetlen ómagyar kori egyénnév eredetének a meghatározásához szolgáltat újabb, könnyen elérhető eszközt, másrészt mert a középkori magyarországi egyénnévállomány eddig feltárt részét is hozzáférhetővé, megismerhetôvé teszi a külföldi névkutatás számára. (A DMNES szerkesztési elveiről, felépítéséről, tartalmáról l. UCKELMAN-SLíz 2015.)

Az egyesített korpusz elemzésével a korábbinál jóval világosabb kép rajzolódik ki előttünk a görög-latin eredetú, az egyház által terjesztett és támogatott egyénnevek erőteljes térhódításának üteméről, illetve ezzel összefüggésben a világi nevek háttérbe szorulásáról, a magyar és török eredetű neveknek a 15-16. századra szinte teljes eltűnéséről. Bár a névtudományi szakirodalomban e változás ténye közhelyként él, valódi mértékét, arányát eddig nagyobb korpuszok híján csak sejthettük. A jelen vizsgálat előzményét képező monográfiámban (SLíz 2011b) ugyan táblázatok segítségével négy, 13-14. századra kiterjedő korszakra bontva már ábrázolni tudtam e változást, most azonban - csaknem kétszer annyi adat birtokában - nemcsak pontosabb képet nyújthattam e változás üteméről, hanem egy újabb korszakkal is meghosszabbíthattam a vizsgálat időbeli látóterét. Az 1343 utáni korszakra vonatkozólag a jelenleg még kiadatlan vagy egyéb okmánytárakban kiadott források, illetve az Anjoukori okmánytár kiadásra váró 8-9. kötetének (vö. TRINGLI - C. TÓTH CSUKOVITS 2008) a feldolgozása szolgálhat újabb információkkal.

A névváltozatok vizsgálatában szintén komoly előrelépést hozott az időhatárok kiterjesztése. Ennek révén feltárhatóvá vált nemcsak a névváltozatok oklevélbeli arányában bekövetkező változás, hanem a nemek névváltozattal való megjelölésének a gyakorisága közötti eltérés is. Emellett az is kirajzolódott, hogy a névváltozatok oklevelekbe való bekerülését nem kizárólag a latin alapnév nagyobb presztízse és a társadalmi hierarchia befolyásolhatta, ennek következtében pedig a névváltozatok 
írásbeli megjelenésének aránya - a korábbi szakirodalom vélekedésével ellentétben, legalábbis a tárgyalt időszakban, a férfinevek esetében - nem mutat társadalmi rétegek szerinti eltérést. További, módszertani szempontból kiemelendő eredmény a névváltozatok kapcsán, hogy bár nyilvánvalóan együttesen, általánosságban is lehet és kell is vizsgálni a névváltozatoknak a latin alapnévhez való viszonyát, illetve az annak erősségében bekövetkező változásokat, folyamatosan szem elôtt kell tartanunk azt is, hogy e viszony erőssége nevenként és változatonként igen eltérő lehetett.

Az ómagyar kori nemesség névadási indítékainak a feltárásában fontos új szempontokra világított rá a genealógia nyújtotta, az eddigi személynévtörténeti kutatások során mindeddig kevéssé kihasznált lehetőségeknek a névöröklés vizsgálatában való kiaknázása. Módszertani szempontból lehet érdekes például annak a részletes bemutatása, hogy miképpen vehetôk figyelembe a genealógiai információk a néveredet meghatározásában. Emellett az is bebizonyosodott, hogy a női és a férfinevek a névöröklés más-más vonásainak a feltárására alkalmasak: az elóbbiek inkább a nevek családok közötti terjedésének, míg az utóbbiak a családon belüli névismétlődésnek a megfigyelésére alkalmasak. A családfák elemzése révén pedig kiderült, hogy az örökítés igen fontos névadási indíték volt a nemesség körében, ugyanakkor ennek mértéke erősen eltérő lehetett: míg egyes családok hagyományőrzőbbek voltak e téren, másokra inkább az újítás, a névkészlet változatossága volt jellemző. Az idegen eredetú nemzetségek a korábbi feltételezésekhez képest jóval kevésbé törekedtek például a származásuknak megfelelő, idegen eredetú nevek választására. Az is kiderült továbbá, hogy nemzetségre jellemző nevekről nemigen lehet beszélni; e nevek ugyanis sokkal inkább kisebb-nagyobb nemzetségágakra vagy még szúkebb hatókörre, egyes családokra korlátozódtak. A vizsgálat során azt is sikerült kimutatnom, hogy az egyenes ági, megszakítatlan névöröklődés felső határa a három-négy generáció; ebben az egyéb névadási indítékoknak az adott esetben erősebbé válása mellett bizonyára szerepük volt a korabeli népesedési és családtörténeti viszonyoknak, így annak is, hogy a férfiágak jó része éppen mindössze három-négy generációt ért meg. A névöröklés vizsgálata emellett az irodalmi eredetú nevek kapcsán is új eredményekre vezetett: eszerint e névtípus elemei jellemzőbben oldalágon öröklődtek, és gyakran nem is maga az adott név, hanem a típusnak egy másik, a családban korábban még elő nem forduló képviselője jelent meg az új nemzedék(ek)ben. Ezt látva a névöröklés fogalmát ki kell terjesztenünk, nem csupán egy adott névre, hanem egy egész névtípusra is értve, azaz a példánygyakoriság mellett a típusgyakoriságot is figyelembe véve.

Az egyesített korpusz feldolgozása kétségkívül a családnevek kialakulásával kapcsolatban szolgáltatta a legtöbb újdonságot. Egyrészt míg a korpusz első, négy évtizedet átfogó részében mindössze öt öröklődő névelemre volt bizonyíték, addig az utóbb feldolgozott tizenhét évből ennek négyszerese került elő. Ez egyrészt a forrásadottságoknak köszönhető, hiszen az oklevelek számának jelentős mértékű növekedése egy-egy család történetének adatoltságát is növelheti, másrészt feltehetôleg a 
családnevek korabeli arányának a növekedésére is utal. Ugyanakkor az ugyanazon személyre vonatkozó személyjelölő szerkezetek nagy változatossága, mely még az újabb korpuszban is megfigyelhető, óvatosságra inti a névkutatást e téren, jelezve, hogy hiba lenne mai családnév fogalmunkat egy az egyben visszavetíteni a korabeli névállományra. Ebben az időszakban ugyanis az egyénnév melletti névelem még meglehetősen instabil, egy-két generációnyi öröklődés után is könnyen eltűnhet vagy másikra cserélődhet, miközben nem ritka, hogy egy-egy családnak még nem minden tagja viseli az adott, már öröklődőnek túnő névelemet.

Szintén hozzájárul az elhamarkodott kijelentések megelőzéséhez a különféle típusú források személyjelölő szerkezeteinek az összevetése. E vizsgálat arra hívta fel a figyelmet, hogy e szerkezetek erősen függenek a forrás típusától (céljától, felépítésétől stb.) is, ezért hiba lenne ezek figyelembevétele nélkül, kizárólag formai szempontok alapján nyilatkozni egy-egy névelem családnév voltáról, illetve a családnevek kialakulásának koráról. Ugyanezt a módszertani következtetést támasztotta alá a 14-15. századi német nyelvű oklevelek személyjelölő szerkezeteinek az elemzésbe való bevonása, a latin nyelvűekkel való összevetése is.

Az egyes személyjelölő szerkezetek társadalmi megoszlásának az elemzése azt is megerősítette, hogy a családnevek kialakulásának ideje, üteme az egyes társadalmi rétegekben feltehetőleg nem tért el jelentős mértékben. E következtetésre jutott már SZABÓ ISTVÁN (1954: 9-11, ill. 1976: 226-227) is az 1522-es Bács, Bodrog és Csongrád megyei tizedjegyzékek névanyagának az áttekintése alapján. E véleményt képviselte HAJDÚ MIHÁLY (2003: 740) is, és korábbi munkámban magam is e következtetésre jutottam, akkor még csupán az egyelemû́ nevek társadalmi megoszlásának a vizsgálata során (SLÍZ 2011b: 234-235). A jelen tanulmány eredményei arra engednek következtetni, hogy az egyes társadalmi rétegekben eltérô arányban megjelenő különféle személyjelölő szerkezetek, illetve egyelemú nevek nem annyira a családnevek létére vagy hiányára, sokkal inkább a személyjelölő szerkezetek gyakoriságának, azaz a személyek megjelölésére használt oklevélírói szokásoknak az időbeli változására és az egyes társadalmi rétegek vonatkozásában eltérő alkalmazására utalnak. E változásoknak, illetve a személyjelölő szerkezetek tipikustól való eltérésének a feltárása emellett az élő névhasználat nyomainak a felfedezésében is segítségünkre lehet.

A személyjelölő szerkezetek társadalmi megoszlásának, valamint a közszói eredetű megkülönböztető névelemeknek a motivációs-jelentéstani elemzése a történeti családnév-tipológiai vizsgálatok számára is számos új eredményt hozott. A családnevek szempontjából legkorábbi névanyagnak az elmúlt években leggyakrabban alkalmazott funkcionális-szemantikai modell alapján történő elemzése ugyanis fontos kiindulópontként szolgálhat az egyes, motiváció szerinti családnévtípusok történeti alakulásának, illetve társadalmi megoszlásának az elemzéséhez. Ilyen jellegú vizsgálatra vállalkozott például újabban FARKAS TAMÁs (2013) a népnévi eredetú, magam pedig legutóbb a foglalkozásnévi eredetű családnevek kapcsán (SLíz 2015b, 
2016b). A továbbiakban érdemes lenne a munkát a többi motivációs típusra is kiterjesztve a teljes magyar családnévállományt leírni e szempontból. Ez egyrészt a magyar személynévkutatás számára is fontos, szükséges, ráadásul a CsnSz. mellett az utóbbi bő évtizedben kiépített nagyobb adatbázisok és családnévtárak (pl. CsnE.; CsnVégSz.; FTSznSz.; MCsvA.; MMCsA.; SLíz 2011a, 2017; TMCsA.; ÚCsnT.) birtokában már viszonylag könnyen elvégezhető feladat lenne. (Ezekről bővebben 1. N. FODOR 2015b, SZILÁGYI-KÓSA 2015.) Másrészt e vizsgálatok révén a magyar családnévállományra vonatkozó ismeretek és eredmények bekapcsolhatók lennének az európai családnévállományt napjainkban feltérképezni igyekvố nemzetközi családnévtipológiai kutatásokba is (ezekről 1. pl. FARKAS 2015, 2016; SHOKHENMAYER 2016).

Míg a 14. századi összesített korpusz elemzése a szakirodalom korábbi megfigyeléseinek a bővítése, kiegészítése, illetve módosítása terén hozott újabb eredményeket, addig a korábban méltatlanul kevés figyelmet kapó német és cseh nyelvű okleveleknek a vizsgálatba való bevonása több, a személynévtörténeti irodalomban alig érintett, pedig a középkori Magyarország soknemzetiségú, soknyelvű voltát ismerve megkerülhetetlen téma áttekintését tette lehetővé. E forrásoknak köszönhetően lehetőségem volt kitérni a magyar és más nyelvek közötti kontaktushatások, valamint a többnyelvű scriptorok által a személynevek oklevélbe illesztése során alkalmazott fordítási stratégiák kérdéskörére. Az előbbi téma vizsgálata elsősorban módszertani tanulságokat hozott: rávilágított arra, hogy mely adatok és milyen mértékben használhatók fel a kontaktológiai kutatás számára. Ennek köszönhetően nyilvánvalóvá vált, hogy a középkori oklevél mint forrástípus is alkalmas lehet e vizsgálatok számára, a ritkán felbukkanó adatok összegyüjtése azonban nagy idő- és munkabefektetést igényel, miközben hasznosíthatóságuk erősen korlátozott.

A fordítás kapcsán a három célnyelv fordítási gyakorlatának az összevetésére és az időbeli változás megfigyelésére is lehetőségem volt a források alapján. Kiderült, hogy a fordítási stratégiák névfajtánként eltérốk voltak, az egyes nyelvekre jellemzô fordítási gyakorlatok között számos hasonlóság figyelhető meg, és az alkalmazott megoldások nagy variabilitása idôvel minden nyelvben jelentősen csökkent. Ez a hasonlóság bizonyára nem független a közös európai oklevélírási mintáktól, a fordítási stratégiák egységesülése pedig meggyőződésem szerint a névrendszerben bekövetkezett változásnak, azaz a családnévrendszer kiépülésének a következménye.

Az itt bemutatott eredmények remélhetôleg nemcsak az ómagyar kori személynévállománynak, a névadási és névhasználati szokásoknak, valamint a családnévtörténet korai szakaszának a megismeréséhez visznek bennünket közelebb, hanem a jövőbeni családnév-tipológiai vizsgálatokban is felhasználhatók lesznek. Kiemelt célom volt emellett módszertani szempontokkal is segíteni a korszak személynévanyagának későbbi kutatását, különös tekintettel egyes társtudományok, így a történettudomány, a genealógia, a fordítástudomány és a kontaktológia alkalmazhatóságára. E vizsgálatok reményeim szerint nemcsak a névkutatásnak, hanem az említett tudományoknak is új adalékokkal szolgálhatnak. 


\section{HIVATKOZOTT IRODALOM}

ANGYAL LÁSZLÓ 2013. Sáros vármegye helységnevei a szlovák fordítások tükrében (Cuius regio, eius nomen?). In: BAUKO JÁNOS - BENYOVSZKY KRISZTIÁN szerk., Tulajdonnevek a forditás és a kétnyelvúség kontextusában. Nyitrai Konstantin Filozófus Egyetem Közép-európai Tanulmányok Kara, Nyitra. 68-85.

AO. = Anjoukori okmánytár 1-7. [1-6.] Szerk. NAGY IMRE. MTA, Budapest, 1878-1891. [7.] Szerk. TASNÁDI NAgY GyULA. MTA, Budapest, 1920.

BAKONYI DÓRA 2008. A szereplók tulajdonneveinek fordítási kérdései a Harry Potter-kötetekben. In: BÖLCSKEI ANDREA - N. CSÁSZI ILDIKÓ szerk., Név és valóság. A VI. Magyar Névtudományi Konferencia elóadásai. Balatonszárszó, 2007. június 22-24. A Károli Gáspár Református Egyetem Magyar Nyelvtudományi Tanszékének Kiadványai 1. Károli Gáspár Református Egyetem Magyar Nyelvtudományi Tanszéke, Budapest. 519-527.

BALÁzs JánOS 1989. A latin a Duna-tájon. In: BALÁzs JÁNOS szerk., Nyelvünk a Duna-tájon. Tankönyvkiadó, Budapest. 95-140.

BÁLINT SÁNDOR 1977. Ünnepi kalendárium. A Mária-ünnepek és jelesebb napok hazai és közép-európai hagyományvilágából 1-2. Szent István Társulat, Budapest.

BÁRCZI GÉZA 1938. A magyar nyelv francia jövevényszavai. A Magyar Nyelvtudomány Kézikönyve I. 12. f $\alpha$. MTA, Budapest.

BÁRCZI ZSÓFIA 2013. Alicek, Alizok és Évikék. Lewis Carroll Alice's Adventure is Wonderland címú regénye névanyagának magyar fordításairól. In: BAUKO JÁNOS - BENYOVSZKY KRISZTIÁN szerk., Tulajdonnevek a forditás és a kétnyelvüség kontextusában. Nyitrai Konstantin Filozófus Egyetem Közép-európai Tanulmányok Kara, Nyitra. 176-183.

Bartha Csilla 1999. A kétnyelvüség alapkérdései. Beszélók és közösségek. Nemzeti Tankönyvkiadó, Budapest.

BASKI IMRE 2007. Csagircsa. Török és magyar névtani tanulmányok 1981-2006. Kunszövetség, Karcag.

BAUKO JÁNOS 2013. Kontaktusjelenségek a szlovákiai magyarok személynévhasználatában. In: VÖRÖS FERENC szerk., A nyelvi köllsönhatások és a személynevek. A nyelvföldrajżól a néveöldrajzig IV. Savaria University Press, Szombathely. 69-78.

BENKÖ LORÁND 1948. Izsó. Magyar Nyelv 44: 55-57.

BENKŐ LORÁND 1948-1949/2003. A családnév-változtatás kérdései. In: Uő, Nyelv és tudomány, anyanyelv és nyelvtudomány. Válogatás Benkö Loránd tanulmányaiból. 1-3. Szerk. HAJDÚ MIHÁLY - KISS JENÓ. ELTE BTK Magyar Nyelvtörténeti, Szociolingvisztikai, Dialektológiai Tanszék, Budapest. 2: 364-381. 
BEREGSZÁSZI ANIKÓ - CSERNICSKÓ ISTVÁN 2011. A kárpátaljai magyar személynevek átírásának és használatának kérdésköréroól. Magyar Nyelvớr 135: 414-422.

BERRÁR JOLÁN 1949. Kunigunda - Kinge. Magyar Nyelv 45: 68-72.

BERRÁR JOLÁN 1950. Belső keletkezéső és egyházi eredetű személyneveink keveredése. Magyar Nyelv 46: 254-256.

BERRÁR JOLÁN 1952. Nói neveink 1400-ig. A Magyar Nyelvtudományi Társaság Kiadványai 80. Magyar Nyelvtudományi Társaság, Budapest.

BÖLCSKEI ANDREA 2009. Az Amerikai Egyesült Államok tagállamainak hivatalos és informális elnevezéseiről, a tagállamnevek magyar fordításáról. Névtani Értesitő 31: 119-141.

BÖLCSKEI ANDREA 2010a. A magyar településnevek korrelációs rendszerének alakulása a természetes névadás korszakában. A Károli Gáspár Református Egyetem Magyar Nyelvtudományi Tanszékének Kiadványai 2. Károli Gáspár Református Egyetem Magyar Nyelvtudományi Tanszéke, Budapest.

BÖLCSKEI ANDREA 2010b. Fordítás, adaptáció és helynévtörténet: magyar és angol helynévtípusok kontrasztív vizsgálatának gyakorlati tanulságairól. Helynévtörténeti Tanulmányok 5: 245-262.

CAWLEY, CHARLES - FMG (Foundation for Medieval Genealogy) 2006-2015. Medieval Lands. A prosopography of medieval European noble and royal families. 3. kiadás. http://fmg.ac/projects/medlands.

CsnE. = HAJDÚ MIHÁLY 2010. Családnevek enciklopédiája. Leggyakoribb mai családneveink. A Magyar Nyelv Kézikönyvei 17. Tinta Könyvkiadó, Budapest.

CsnSz. = KÁZMÉR MIKLÓS 1993. Régi magyar családnevek szótára. XIV-XVII. század. Magyar Nyelvtudományi Társaság, Budapest.

CsnVégSz. = Régi magyar családnevek névvégmutató szótára. XIV-XVII. század. Szerk. FARKAS TAMÁS - F. LÁNCZ ÉvA ANNA. ELTE Magyar Nyelvtudományi és Finnugor Intézet - Magyar Nyelvtudományi Társaság, Budapest, 2009.

DMNES = Dictionary of Medieval Names from European Sources. Fószerk. SARA L. UCKELMAN. http://dmnes.org/.

ENGEL PÁL 2003. Középkori magyar genealógia. In: Arcanum DVD könyvtár 4. Családtörténet, heraldika, honismeret. Arcanum, Budapest.

FÁBIÁN ZSUZSANNA 2004. A tulajdonnevek Collodi Le avventure di Pinocchio címú könyvének magyar fordításaiban. In: SZÖRÉNYI LÁSZLÓ - TAKÁCS JÓZSEF szerk., Serta Jimmyaca. Emlékekönyv Kelemen János 60. születésnapjára. Balassi Kiadó, Budapest. 311-326.

FALLENBÜCHL ZOLTÁN 1991. Névkutatás és családtörténet. Névtani Értesitő 13: 48-53.

FARKAS TAMÁs 2007. A tulajdonnevek fordíthatóságáról és napjaink fordítási hibáiról, közszók és tulajdonnevek példáján. Névtani Errtesitő 29: 167-188.

FARKAS TAMÁS 2009a. A tulajdonnevek fordításának alapkérdéseiről. Diadal vagy Viktória, Eugén vagy Jenó? Fordítástudomány 11/2: 22-35. 
FARKAS TAMÁs 2009b. Családnévrendszer, névhasználat, névváltozás nyelvikulturális kontaktushelyzetben. Névtani Értesitó 31: 27-46.

FARKAS, TAMÁS 2009c. Surnames of Foreign Origin in a Language Contact Situation. The Reasons and Ways of Their Changes and Their Influence on the Surname Stock in Hungary. In: AHrENS, WOLFGANG - EMBLETON, SHEILA - LAPIERRE, ANDRÉ eds., Names in Multi-Lingual, Multi-Cultural and Multi-Ethnic Contact. Proceedings of the 23rd International Congress of Onomastic Sciences. August 17-22, 2008, York University, Toronto, Canada. York University, Toronto. 365-374.

FARKAS TAMÁs 2010. A -fi végú magyar családnevek típusai és története. Névtani Értesitó 32: 9-31.

FARKAS TAMÁS 2011. Franciás műveltség, magyar nyelv és a tulajdonnevek fordítása. In: CSISZÁR GÁBOR - DARVAS ANIKÓ szerk., Klárisok. Tanulmánykötet Korompay Klára tiszteletére. ELTE Magyar Nyelvtörténeti, Szociolingvisztikai, Dialektológiai Tanszéke, Budapest. 109-116.

FARKAS, TAMÁS 2013. Surnames of Ethnonymic Origin in the Hungarian Language. In: Felecan, Oliviu ed., Proceedings of the Second International Conference on Onomastics „Name and Naming”. Onomastics in Contemporary Public Space. Editura Mega, Cluj-Napoca. 504-517.

FARKAS, TAMÁS 2015. The most frequent Hungarian surnames. A study of some aspects of contrastive surname typology. In: FELECAN, OLIVIU ed., Name and Naming. Proceedings of the Third International Conference on Onomastics "Name and Naming". Conventional / Unconventional in Onomastics. Baia Mare, September 1-3, 2015. Editura Mega - Editura Argonaut, Cluj-Napoca. 122-136.

FARKAS TAMÁS 2016. A magyar családnévanyag kontrasztív szempontú tipológiaistatisztikai vizsgálata. Névtani Értesitổ 38: 33-52.

FARKAS, TAMÁS - SLÍZ, MARIANN 2013. Translating Family Names in Hungarian: A Diachronic Survey. AHEA: E-Journal of the American Hungarian Educators Association 6. https://ahea.pitt.edu/ojs/index.php/ahea/article/view/114 és https:// doi.org/10.5195/ahea.2013.114 (2016. 01. 25.)

FEHÉRTÓI KATALIN 1969. A XIV. sqáąadi magyar megkülönböztetó nevek. Nyelvtudományi Értekezések 68. Akadémiai Kiadó, Budapest.

FEHÉRTÓI KATALIN 1975. Genealógia és névkutatás. Magyar Nyelv 71: 456-458.

FEHÉRTÓI KATALIN 1997. Árpád-kori közszói eredetű személyneveinkről. Magyar Nyelvốr 121: 71-75.

FEHÉRTÓi KATALIN 1998. A -fi, -fia utótagú magyar családnevek kialakulása. Magyar Nyelvör 122: 458-467.

FEJÉRPATAKY LÁSZLÓ 1918. Hiteleshely mint névmagyarázó. Magyar Nyelv 14: 169-173.

FEKETE ANTAL 2007³. Keresztneveink, védőszentjeink. Szent István Társulat, Budapest.

FNESz. ${ }^{4}=$ KISS LAjOS 1998. Földrajzi nevek etimológiai szótára 1-2. Akadémiai Kiadó, Budapest. 
N. FODOR JÁNOS 2004. Adalékok a helynévi eredetű családnevek kialakulásához - A Gutkeled nemzetség szólátmonostori ágának családnevei. Névtani Értesitő 26: 31-45.

N. FODOR JÁNOS 2008a. A magyar családnevek új szempontú rendszerezési lehetôségéröl. Magyar Nyelv 104: 286-305.

N. FODOR JÁNOS 2008b. Egy német ajkú deák által lejegyzett szabolcsi összeírás a XVI. század első évtizedeiből. Magyar Nyelv 104: 254-256.

N. Fodor János 2010. Személynevek rendszere a kései ómagyar korban. A Felsö-Tiszavidék személyneveinek nyelvi elemzése (1401-1526). Magyar Névtani Értekezések 2. ELTE BTK Magyar Nyelvtudományi és Finnugor Intézet, Budapest.

N. FODOR JÁNOS 2014. A történeti személynévföldrajz mint a nyelvföldrajz egyik kutatási területe I. A nyelvföldrajzi módszer a névtani kutatásokban. Névtani Értesitô 36: 23-41.

N. FODOR JÁNOS 2015a. Language contact effects in historical Hungarian and Romanian personal names. In: FELECAN, OlIVIU ed., Name and Naming. Proceedings of the Third International Conference on Onomastics "Name and Naming". Conventional / Unconventional in Onomastics. Baia Mare, September 1-3, 2015. Editura Mega - Editura Argonaut, Cluj-Napoca. 163-173.

N. FODOR JÁNOS 2015b. Történeti személynévkutatás. In: FARKAS TAMÁS - SLíz MARIANN szerk., Magyar névkutatás a 21. század elején. Magyar Nyelvtudományi Társaság - ELTE Magyar Nyelvtudományi és Finnugor Intézet, Budapest. 115-144.

Förstemann, ERnst 1900/1966². Altdeutsches Namenbuch. 1. Personennamen. Wilhelm Pink Verlag, München; Georg Olms Verlagsbuchhandlung, Hildesheim. Reprint.

FTSznSz. = N. FODOR JÁNOS 2010. A Felsó-Tisza-vidék késö középkori személyneveinek szótára (1401-1526). Magyar Nyelvtudományi Értekezések 3. ELTE Magyar Nyelvtudományi és Finnugor Intézet Magyar Nyelvtörténeti, Szociolingvisztikai, Dialektológiai Tanszéke, Budapest.

FÜGEDI ERIK 1974. Uram, királyom... A XV. századi Magyarország hatalmasai. Gondolat Kiadó, Budapest.

FÜGEDI ERIK 1986. Ispánok, bárók, kiskirályok. A középhoori magyar arisztok rácia fejlödése. Magvető Kiadó, Budapest.

GULYÁS LÁSZLÓ SZABOLCS 2008. Középkori mezôvárosi foglalkozásneveink forrásértékérôl. Századok 142: 437-462.

GULYÁS LÁSZLÓ SZABOLCS 2015. A középkori magyar városfejlődés migráció- és ipartörténeti vonatkozásai a történeti személynévtan tükrében II. Személynévadás és kézmúipar. Névtani Értesitón 37: 137-156.

GYÖRFFY GYÖRGY 1970. A helynevek és a történettudomány. In: KÁZMÉR MIKLÓS VÉGH JÓZSEF szerk., Névtudományi elöadások. II. Névtudományi Konferencia 1969. Nyelvtudományi Értekezések 70. Akadémiai Kiadó, Budapest. 196-200. 
Hajdú Mihály 2003. Általános és magyar névtan. Személynevek. Osiris Kiadó, Budapest.

HEGEDỨs ATTILA 2010. A jo/ju $i$ váltakozás régi helyneveink tükrében. Helynévtörténeti Tanulmányok 5: 7-15.

HERTELENDY RÉKA 2011. Fordítói kihívások és megoldások a magyar nyelvú Harry Potter-kötetekben. Névtani Értesitón 33: 133-145.

HOkl. = Hazai oklevéltár 1234-1536. Szerk. NAGY IMRE - DEÁK FARKAS - NAGY GYULA. Magyar Történelmi Társulat, Budapest, 1879.

HOFFMANN ISTVÁN 2004. Az oklevelek helynévi szórványainak nyelvi hátteréról. Helynévtörténeti Tanulmányok 1: 9-61.

HofFMANN IstVÁN 2008. A személynévrendszerek leírásához. Magyar Nyelyjárások 46: 5-20.

HéOkl. $=$ A Héderváry-család oklevéltára 1-2. Szerk. RADVÁNSZKY BÉLA - ZÁvODSZKY LEVENTE. MTA, Budapest, 1909-1922.

HORVÁTH PÉTER IVÁN 2008. Személynevek a szakfordításban. Névtani Értesitó 30: $35-40$.

IMREH RÉKA 2014. A helynevek szerepe az alternatív ideologikus gondolkodásban I. A Pilis-kultusz esete. Névtani Értesitó 36: 105-120.

IMREH RÉKA 2015. A helynevek szerepe az alternatív ideologikus gondolkodásban II. Tudálékos helynév-etimológiák és új helynevek a Pilis-kultuszból. Névtani Értesitó 37: 119-136.

JANITSEK JENŐ 1997. A magyar eredetű román családnevekről. In: B. GERGELY PIROSKA - HAJDÚ MIHÁLY szerk., Az V. magyar névtudományi konferencia elöadásai (Miskolc, 1995. angusztus 28-30) 1-2. A Magyar Nyelvtudományi Társaság Kiadványai 209. Budapest-Miskolc. 1: 101-107.

KárOkl. = A nagy-károlyi gróf Károlyi család okelevéltára 1-5. Szerk. GÉRESI KÁLMÁN. [1-2] Kocsi Sándor, [3-5] Franklin-Társulat Könyvnyomdája, Budapest, 1882-1897.

KÁZMÉr MiKLós 1967. A -si képző nyelvföldrajzához. Magyar Nyelv 63: 345-348.

KÁZMÉR MIKLÓs 1970. XIV-XVIII. századi tulajdonnevek nyelvtörténeti értékesítése. (A -si képző kialakulása). In: KÁZMÉR MIKLÓS - VÉGH JÓZSEF szerk., Névtudományi elöadások II. Névtudományi Konferencia 1969. Nyelvtudományi Értekezések 70. Akadémiai Kiadó, Budapest. 60-69.

KNIEZSA IsTVÁN 1952. Köžépkori cseh oklevelek. Magyarországi szláv nyelvemlékek 1. Akadémiai Kiadó, Budapest.

KNIEZSA ISTVÁN 1965/2003. A magyar és a szlovák családnevek rendszere. In: Uó, Helynév-és családnév-vizsgálatok. Lucidus Kiadó, Budapest. 255-349.

KOHLHEIM, ROSA - KOHLHEIM, VOLKER 2005. Duden Familiennamen. Dudenverlag, Mannheim-Leipzig-Wien-Zürich.

KOROMPAY KLÁRA 1978. Középkori neveink és a Roland-ének. Nyelvtudományi Értekezések 96. Akadémiai Kiadó, Budapest. 
KOROMPAY KLÁRA 1980. Név és névváltozat a keresztnevek történeti vizsgálatában. In: IMRE SAMU - SZATHMÁRI ISTVÁN - SZÜTS LÁSZLÓ szerk., A magyar nyelv grammatikéja. A Magyar Nyelvészęe. III. Nemzetközi Kongresszusának elöadásai. Nyelvtudományi Értekezések 104. Akadémiai Kiadó, Budapest. 519-524.

KOROMPAY KLÁRA 2008. Középkori kultúra és irodalmi eredetű névadás: a Trisżtánregény nevei a középkori Magyarországon. In: BÖLCSKEI ANDREA - N. CSÁsZI ILDIKÓ szerk., Név és valóság. A VI. Magyar Névtudományi Konferencia elöadásai. Balatonszárszó, 2007. június 22-24. A Károli Gáspár Református Egyetem Magyar Nyelvtudományi Tanszékének Kiadványai 1. Károli Gáspár Református Egyetem Magyar Nyelvtudományi Tanszék, Budapest. 387-394.

KOROMPAY, KLÁRA 2011. La Chanson de Roland et la Hongrie médiévale : du nouveau sur Elefant. In: EGEDI-KOVÁCS, EMESE ed., Littérature et folklore dans le récit médiéval. Actes du colloque des 4-5 juin 2010. Collège Eötvös József ELTE, Budapest. 173-183.

KOROMPAY, KLÁRA 2012. L'anthroponymie de la Hongrie médiévale et le Roman de Tristan. In: EgEDI-KOvÁcs, EMESE ed., Dialogue des cultures courtoises. Collège Eötvös József ELTE, Budapest. 173-192.

KRISTÓ GYULA 1998. Magyarország története 895-1301. Osiris Tankönyvek. Osiris Kiadó, Budapest.

KUBINYI ANDRÁs 2003. Családnévadás a középkori Magyarországon. In: STIRLING JÁNOS szerk., In virtute spiritus. A Szent István Akadémia emlékkeönyve Paskai László biboros tis zteletére. Szent István Társulat, Budapest. 96-112.

KURCZ ÁGNES 1988. Lovagi kultúra Magyarországon a 13-14. században. Akadémiai Kiadó, Budapest.

LANSTYÁK ISTVÁN 2013. Kontaktushatás a tulajdonnevekben. In: VÖRÖS FERENC szerk., A nyeluföldrajztól a névföldrajzig IV. A nyelvi kölcsönhatások és a személynevek. A 2013. június 8-i dunaszerdahelyi tanácskozás elöadásai. Savaria University Press, Szombathely. 43-68.

B. LŐRINCZY ÉVA 1962. Képzó- és névrendszertani vizsgálódások. Az-s -cs képzóvel alakult névanyag az ómagyarban. Nyelvtudományi Értekezések 33. Akadémiai Kiadó, Budapest.

MCsvA. = Magyarországi bivatalos családnév-válto ztatások történeti adatbázisa (1815-1932). Kutatásvezetô: FARKAS TAMÁs - KÖVESDI ISTVÁN. http://www.macse.hu/society/ nevvaltoztatasok.php (2015. 05. 11.)

MELICH JÁNOS 1943. Családneveinkről. Magyar Nyelv 39: 265-289.

MEZỎ ANDRÁs 1970. A Várdai-birtokok jobbágynevei a XV. század közepén. Kisvárdai Vármúzeum, Kisvárda.

MIKESY SÁNDOR 1959. Miért alakultak ki vezetékneveink? Magyar Nyelvör 83: 82-87.

MKL. = Magyar katolikus lexikon 1-14. Főszerk. Diós IsTVÁN. Szent István Társulat, Budapest, 1993-2009.

MMCsA. = A mai magyar családnevek adatbázisa 2009. Digitálisan tárolt adatbázis. Kutatásvezető: VÖRÖS FERENC. 
MOLLAY KÁROLY 1936. Középkori soproni családnevek. Német Nyelvészeti Dolgozatok 1. K. n., Budapest.

MOLLAY KÁROLY 1982. Német-magyar nyelvi érintkezések a XVI. század végéig. Akadémiai Kiadó, Budapest.

MOÓR, ELEMÉR 1937. Die Anfänge der höfischen Kultur in Ungarn. Ungarische Jabrbücher 17: 57-86.

MUUnk. = LADÓ JÁNOS - BíRÓ ÁGNES 1998. Magyar utónévkönyv. Vince Kiadó, Budapest.

NÓGRÁDY ÁRPÁD 2011. Kaniæsai Lásžló sæámadáskönyve. MTA Történettudományi Intézet, Budapest.

NyíRI ANTAL 1963. A Farkas személynév eredetéhez. Néprajz és Nyelvtudomány 7: 82-83.

OnomTurc. $=$ RÁSONYI LÁSZLÓ - BASKI IMRE 2007. Onomasticon Turcicum - Turkic Personal Names 1-2. Indiana University, Bloomington.

PAIS DEZSŐ 1932. R. F. In: Levélszekrény rovat. Magyar Nyelv 28: 323-324.

PAPP LÁSZLÓ 1958. Néhány szó becéző személyneveinkrôl. Magyar Nyehơor 80: 454-457.

PERGER IMRE 2013. A határon túli vasútállomások neve a vasúti utastájékoztatásban. Névtani Értesitó 35: 77-96.

PT. = Rationes Collectorum Pontificiorum in Hungaria. Pápai tized-szedók számadásai 1281-1375. Monumenta Vaticana Hungariae. Budapest, 1887.

RÁCZ ANITA 2009. Nyugati népek megnevezéseinek változásai a magyar nyelvben. Magyar Nyelyjárások 47: 81-97.

RÁCZ ENDRE 1956a. A becéző nevek megkülönböztető szerepéről. Nyelv és Irodalom 2: 133-139.

RÁCZ ENDRE 1956b. Az ikerítéssel alakult becézô nevek történetéhez. Magyar Nyelv 52: 48-52.

RÁCZ ENDRE 1959-1960. Rövidüléssel alakult becéző nevek a XIV. században. Néprajzés Nyelvtudomány 3-4: 69-84.

RÁCZ ENDRE 1960. Néhány szempont becéző keresztneveink vizsgálatához. In: MiKeSY SÁNDOR - PAIS DEZSÓ szerk., Névtudományi vizsgálatok. A Magyar Nyelvtudományi Társaság névtudományi konferenciája 1958. Akadémiai Kiadó, Budapest. 146-149.

RiHMER ZOLTÁN 2008. Fordítás vagy adaptáció? A modern latin személynévhasználat problémái. In: BÖLCSKEI ANDREA - N. CSÁSZI ILDIKÓ szerk., Név és valóság. A VI. Magyar Névtudományi Konferencia elöadásai. Balatonszárszó, 2007. június 22-24. A Károli Gáspár Református Egyetem Magyar Nyelvtudományi Tanszékének Kiadványai 1. Károli Gáspár Református Egyetem Magyar Nyelvtudományi Tanszéke, Budapest. 450-460.

SeIBICKe, Wilfried 1982. Die Personennamen im Deutschen. Walter de Gruyter, Berlin - New York. 
ShoKhenmayer, Evgeny 2016. Comparative Study of the 100 Most Frequent Russian, French, German and British Surnames. In: CAROLE HOUGH - DARIA IZDEBSKA eds., Names and Their Environment. Proceedings of the 25th International Congress of Onomastic Sciences, Glasgow, 15-19 August 2014. 1-5, University of Glasgow, Glasgow. 3: 221-232. http://www.icos2014.com/wp-content/uploads/ icos2014_v3 221.pdf (2017. 07. 10.)

Slíz Mariann 2000. Az Árpád-ház névadása Géza fejedelemtöl III. Andrásig. Magyar Névtani Dolgozatok 168. ELTE, Budapest.

SLíz MARIANN 2008. Az oklevélírási gyakorlat hatása a családnevek kialakulására a XIV. században. Magyar Nyelv 104: 186-196.

SLíz MARIANN 2009. Családnév vagy személyjelölő szerkezet? Szempontok az Anjou-kori személynevek vizsgálatához. Magyar Nyelv 105: 291-300.

Slíz MARIANN 2010. A történeti személynévkutatás terminológiájához. Névtani Értesitó 32: 157-172.

SLíz MARIANN 2011a. Anjou-kori személynévtár (1301-1342). Históriaantik, Budapest.

SLÍZ MARIANN 2011b. Személynévadás az. Anjou-korban. Históriaantik, Budapest.

SLíZ MARIANN 2012a. Kommunikációelmélet és szövegtan a történeti személynevek kutatásában. In: BALÁZS GÉZA - VESZELSZKI ÁGNES szerk., Nyelvés kultúra, kulturális nyelvészet. Magyar Szemiotikai Tanulmányok 25-26. Inter Kultúra-, Nyelv- és Médiakutató Központ Kht. - Magyar Szemiotikai Társaság PRAE.HU Kft. - Palimpszeszt Kulturális Alapítvány, Budapest. 297-300.

SLÍZ, MARIANN 2012b. Tristan and Ehelleus. Names derived from literature in Angevin Hungary. In: EGEDI-KOVÁCS, EMESE ed., Dialogue des cultures courtoises. Collège Eötvös József ELTE, Budapest. 261-269.

SLíz MARIANN 2013a. Névtörténet, genealógia és mikrotörténelem. Helynévtörténeti Tanulmányok 9: 139-152.

SLíz MARIANN 2013b. A személynevek mint az ómagyar kori magyarországi kétnyelvűség vizsgálatának forrásai. In: VÖRÖS FERENC szerk., A nyelvföldrajztól a névföldrajzig IV. A nyelvi kölcsönhatások és a személynevek. A 2013. június 8-i dunaszerdahelyi tanácskozás elöadásai. Savaria University Press, Szombathely. 145-153.

SLíz, MARIANN 2013c. Names of Saints and Dynastic Name-giving in Central and Eastern Europe in the 10-14th centuries. Onoma 48. 157-183. https://doi.org/10. 2143/ONO.48.0.0000000.

SLíz, MARIANN 2015a. Byzantine Influence on the Name-giving Practises of the Hungarian Árpád Dynasty. In: EGEDI-Kovács, EMESE ed., Byzance et l'Occident II. Tradition, transmission, traduction. Collège Eötvös József ELTE, Budapest. 171-181.

SLÍZ, MARIANN 2015b. Occupational Names in the Hungarian Family Name System. In: Felecan, OliviU ed., Name and Naming. Proceedings of the Third International Conference on Onomastics "Name and Naming". Conventional / Unconventional in Onomastics. Baia Mare, September 1-3, 2015. Editura Mega - Editura Argonaut, Cluj-Napoca. 328-338. 
Slíz, MARIANN 2016a. Personal Names Originating from Literature or Motion Picture in the Hungarian Name Stock - A Historical Survey. In: CAROLE Hough - Daria IZDebska eds., Names and Their Environment. Proceedings of the 25th International Congress of Onomastic Sciences, Glasgow, $15-19$ August 2014. 1-5, University of Glasgow, Glasgow. 3: 247-254. http://www.icos2014.com/wpcontent/uploads/icos2014 v3 247.pdf.

SLíZ MARIANN 2016b. A foglalkozásnévi eredetű családnevek típusa a magyar családnevek rendszerében. Egy történeti névtipológiai vizsgálat tanulságai. Névtani Értesitó 38: 53-66.

Slíz MARIANN 2017. Anjou-kori személynévtár (1343-1359). Magyar Nyelvtudományi Társaság, Budapest.

J. SOltész KatAlin 1979. A tulajdonnév funkciója és jelentése. Akadémiai Kiadó, Budapest.

SOLYMOSI LÁsZLÓ 2006. Oklevéltan. In: BERTÉNYI IVÁN szerk., A történelem segédtudományai. A Történettudomány Kézikönyve I. Osiris Kiadó, Budapest. 153-168.

SoprT. = Sopron szabad királyi város története I/1-7, II/1-6. Kiad. HÁZI JENÖ. Székely és Tsa, Sopron, 1921-1943.

SZABÓ IsTVÁN 1954. Bács, Bodrog és Csongrád megye dézsmalajstromai 1522-böl. A Magyar Nyelvtudományi Társaság Kiadványai 86. Akadémiai Kiadó, Budapest.

SZABÓ ISTVÁN 1976. A jobbágynevek kialakulása. In: SZABÓ ISTVÁN, Jobbágyokparasztok. Értekezések a magyar parasztság történetéböl. Szerk. FÜR LAJOS. Akadémiai Kiadó, Budapest. 223-236.

SZÉKELY GYÖRGY 1970. A személynevek és a történettudomány. In: KÁZMÉR MIKLÓs - VÉGH JÓZSEF szerk., Névtudományi elöadások. II. Névtudományi Konferencia 1969. Nyelvtudományi Értekezések 70. Akadémiai Kiadó, Budapest. 201-208.

SZENTGYÖRGYI RUDOLF 2007. Egyéni és közösségi kétnyelvűség. Történeti szociolingvisztikai esettanulmány. In: BENŐ ATTILA - FAZAKAS EMESE - SZILÁGYI N. SÁNDOR szerk., Nyelvek és nyelvváltozatok. Köszöntö kötet Péntek. János tisz̨teletére 1-2. Anyanyelvápolók Erdélyi Szövetsége, Kolozsvár. 2: 333-343.

SZENTGYÖRGYI RUDOLF 2010. Helynevek beillesztése korai latin nyelvú okleveleink szövegébe. Helynévtörténeti Tanulmányok 5: 33-45.

SZENTGYÖRGYI RUDOLF 2012. Név, anyanyelv, identitás összefüggései a középmagyar kor boszorkánypereinek tükrében. Helynévtörténeti Tanulmányok 7: 133-142.

SZENTGYÖRGYI RUDOLF 2013. A Tihanyi alapítólevél személynevei II. Az alapítólevél hagionimái. Névtani Értesitó 35: 157-178.

SZILÁGYI-KÓSA ANIKÓ 2015. Mai személynevek kutatása. In: FARKAS TAMÁS - SLÍZ MARIANN szerk., Magyar névkutatás a 21. század elején. Magyar Nyelvtudományi Társaság - ELTE Magyar Nyelvtudományi és Finnugor Intézet, Budapest. 145-164.

TAUBER, WALTER 1993. Mundart und Schriftsprache in Bayern (1450-1800). Walter de Gruyter, Berlin - New York. https://doi.org/10.1515/9783110857139. 
TESz. = A magyar nyelv történeti-etimológiai szótára 1-4. Fôszerk. BENKŐ LORÁND. Akadémiai Kiadó, Budapest, 1967-1984.

TMCsA. = Történeti magyar családnévatlasz. 1715, 1720. Digitálisan tárolt adatbázis. Kutatásvezető: N. FODOR JÁNOS.

TÓTH VALÉRIA 2007. A templomcímből alakult településnevek keletkezési körülményeiről. Magyar Nyelv 103: 408-419.

TÓTH VALÉRIA 2013. Szempontok a középkori források személynévi adatainak értékeléséhez. Nyelvtudományi Közlemények 109: 227-254.

TÓTH VALÉRIA 2014a. A személynévadás és személynévhasználat névelméleti kérdései. Helynévtörténeti Tanulmányok 10: 179-204.

TÓTH VALÉRIA 2014b. Szempontok a 13-14. századi nemzetségnevek értékeléséhez. Századok 148: 471-494.

TÓTH VALÉRIA 2015. Szempontok latin eredetú személyneveink névtörténeti értékeléséhez. A Desiderius névbokra alapján. In: BÁRTH M. JÁNOS - BODÓ CSANÁD - Kocsis Zsuzsanna szerk., A nyelv dimenziói. Tanulmányok Jubász Dezsō tisz. teletére. ELTE BTK Magyar Nyelvtörténeti, Szociolingvisztikai, Dialektológiai Tanszék, Budapest. 437-447.

TÓTH VALÉRIA 2016. Személynévadás és személynévhasználat az ómagyar korban. A Magyar Névarchívum Kiadványai 38. Debreceni Egyetemi Kiadó, Debrecen.

TÖRÖK TAMÁs 2012. Helynevek és fordítástudomány. A mikrotoponimák fordíthatóságáról felvidéki példák alapján. Helynévtörténeti Tanulmányok 7: 117-132.

TRINGLI ISTVÁN - C. TÓTH NORBERT - CSUKOVITS ENIKŐ 2008. Anjoukori okmánytár 8-9. kötet. Munkabeszámoló. http://real.mtak.hu/1606/ (2015. 09. 27.)

THULLNER ISTVÁN 2001. A Moson megyei Heideboden és heidebauerek (a mi németjeink). In: SZENTKUTI KÁROLY szerk., A Hansági Múzeum Évkönyve 1999-2000. Hansági Múzeum, Mosonmagyaróvár. 50-68.

UCKELMAN, SARA L. - SLíZ MARIANN 2015. Többnyelvú névtani lexikográfia: a Dictionary of Medieval Names from European Sources elnevezésú nemzetközi szótári projekt. Névtani Értesitó 37: 203-220.

UCKELMAN, JOEL - UCKELMAN, SARA L. 2016. Yolanda. In: UCKELMAN, SARA L. ed., The Dictionary of Medieval Names from European Sources. Edition 2016, no. 1. http://dmnes.org/2016/1/name/Yolanda.

ÚCsnT. = HAJDÚ MIHÁLY 2012. Újmagyarkori családneveink, tára. XVIII-XXI. század. I. Adatok. Szerzői kiadás, Budapest.

VAJAY SZABOLCS 1968. A magyar Roland-ének nyomában. Irodalomtörténeti Közlemények 72: 333-337.

VÁRNAI JUDIT SZILVIA 2005. Bárhogy nevezæü̈... A tulajdonnév a nyelvben és a nyelvészetben. Tinta Kiadó, Budapest.

Vermes Albert PÉTER 2005a. Proper names in translation: A relevance-theoretic analysis. Kossuth Egyetemi Kiadó, Debrecen. 
VERMES ALBERT PÉTER 2005b. Proper names in translation: A relevance-theoretic analysis. Névtani Értesitö 27: 311-314.

VeszprUrb. = KREDICS LÁSZLÓ - SOLYMOSI LÁSZLÓ 1993. A vesaprémi püspö̈eség 1524. évi urbáriuma. Új Történelmi Tár 4. Akadémiai Kiadó, Budapest.

VÖRÖS FERENC 2005. Hely- és személynévi neologizmusok a Felvidéken Trianon után. Névtani Értesitó 27: 197-213.

VÖRÖS FERENC 2010. Családnevek térképlapjainak nyelvföldrajzi vallomása. A Magyar Nyelvtudományi Társaság Kiadványai 235. Magyar Nyelvtudományi Társaság, Budapest.

VÖRÖS FERENC 2011a. A »falu« névrészt tartalmazó családnevek és a nyelvföldrajæ: Savaria University Press, Szombathely.

VÖRÖS FERENC 2011b. Névföldrajz és térinformatika. In: VÖRÖS FERENC szerk., Családnév - belynév - kisebbségek. A nyeluföldrajztól a névföldrajzig II. A 2011. november 5-i györi tanácskozás elöadásai. Savaria Univeristy Press, Szombathely. 13-44.

VÖRÖS FERENC 2012. Személynévhasználat és impériumváltások a 20. századi Kárpátalján. Magyar Nyelvör 136: 78-88.

VÖRÖS FERENC 2017. Kárpát-medencei történeti családnévatlas: Pesti Kalligram, Budapest.

WERTNER MÓR 1916-1917. Régi magyar női nevek. Magyar Nyelvốr 45: 145-152, 202-210, 298-318, 359-373; 46: 10-18, 83-90. 



\section{Summary}

1. Stemming from its topic, and central corpus this volume should be considered the continuation of the monograph entitled Personal names in Medieval Hungary (2017). Its main source is a base corpus that contains 20,000 entries compiled by the author from extant documents written between 1301-1359. The first part of the corpus was published as a name dictionary in 2011 entitled Anjou-kori személynévtár (1301-1342) [Given names from Angevin Hungary (1301-1342)], this volume will be followed by the Anjoukori személynévtár (1342-1359) [Given names from Angevin Hungary (1342-1359)] dictionary to be published in 2017. Because of name phrases containing patronyms this corpus offers information on name giving and the name stock until the $1220 \mathrm{~s}$. Other sources (indicated in the relevant sections) were also used in the study of the $14^{\text {th }}-16^{\text {th }}$ centuries.

The three main goals of the volume are: (1) to examine the composition of the given name stock according to the origin of names, social diversity and its change over time, as well as the formation of the family name system and the causes of other unique phenomena; (2) to analyse the practice of using given names in the manuscripts of the period; (3) to adapt new methodological approaches to studying the topics above. As the following will illustrate these three goals complement one another in the volume: the new methods are used to present the interwoven examination of the name stock and the characteristics of documents written in the period.

2. Following the first chapter which details the goals, sources and methods of the volume, the first large chapter (Given names) offers an overview of the changes in, and social diversity of the given name stock of each gender in $13^{\text {th }}-14^{\text {th }}$-century Hungary. This is followed by a summary of the connections between name variants and the popularity of certain names within the inheritance of names from several perspectives.

2.1. One of the basic principles of examining a given name stock according to its origin is that any categorisation should follow not the original etymon of the name, but the language from which it was borrowed, as this is the only way the lingual characteristics of the age may be illustrated authentically. Therefore, the name Ádám ('Adam') the etymon of which is Hebrew should be considered a name of Greek-Latin origin, as it entered use in Hungarian through liturgical Latin. Regarding the temporal changes of the name stock it can be said that secular names of any origin (Hungarian, Turkish, German, Slavic, French) were outnumbered by names with ecclesiastical backgrounds by the second decade of the $13^{\text {th }}$ century. The popularity of the latter category is clearly connected to Greek-Latin names from the Bible and martyrologies. Fewer biblical names from the Old Testament were in use, and these were also rarer than names from the New Testament or martyrologies.

The sharp decline in the popularity of secular names (which dropped to $10 \%$ of the name stock by the middle of the $14^{\text {th }}$ century) was not caused by an increase in the 
variety of ecclesiastic names in use, but by a drastic increase in the popularity of certain names. The most well documented social strata - that of landowners - illustrates this tendency. While in the first half of the $13^{\text {th }}$ century 1.25 name bearers shared a name, by the middle of the $14^{\text {th }}$ century 14 name bearers had the same name. The largest increases can be noted in the popularity of names connected to newer religious orders and the cults propagated by Hungarian rulers: the name Domonkos ('Dominic'), for example, became popular after the Dominican Order appeared and spread quickly throughout Hungary in the $13^{\text {th }}$ century; the names of (Saint) Stephen I (István), (Saint) Ladislaus I (László), as well as Saint Elizabeth of Hungary (Erzsébet) and Saint Margaret of Hungary (Margit) were popular because the Árpád and Angevin dynasties supported the cults of their forbearers for domestic and foreign political gains. The popularity of knight saints in the period also contributed to the higher usage of names such as László ('Ladislaus') and György ('George').

Differences in the name giving fashion of the separate social classes can also be observed, however, due to the nature of extant sources from the period data on the lower classes is much scarcer than that on the upper classes. For example, in the name stock of city dwellers names of German or French origin appear in a greater proportion as citizens mainly came from German or Walloon areas (their population varied by region and city). These differences can be pinpointed on certain names. For example, László ('Ladislaus') - most probably due to royal support - was the fifth most common name among the nobility, while it was tenth among serfs, however, the name was less popular among city dwellers.

2.2. Chapter 2.4. examines the variants of given names. Names loaned from foreign languages underwent a series of phonetic and morphological changes which lead to the formation of several variants. Accurately separating these from one another is not a simple task due to the inconsistent orthography of the period. Moreover, the same name variant could form from two different names, or may even have been the Hungarian version and loaned foreign version of the same name. Manuscripts and documents from the period generally contain the Latin or Latinised forms of names, which can be considered standardised to the norms of the age, however, in rare cases the spoken forms of names were also used. An analysis of the use of spoken name forms by gender indicates that the spoken variants of female names were used more commonly than the spoken forms of male names in the documents of the age. One of the reasons for this may be that the ecclesiastical name stock of the time contained less female names than male names, thus authors attempted to decrease the commonality of certain names through the use of variants. Another reason may be the social role of women in the period. Reduced to a subordinate role women's names were less important from a legal perspective; thus, their names were noted with less care, and the processes of standardisation had less of an effect on them. In addition, it is also possible that using the spoken variants of names underlined the subordinate social role of women through their hypocoristic nature. Viewed over time on the larger dataset of male names it can be seen that while name variants accounted for $15 \%$ of the name stock at the end of the $13^{\text {th }}$ century their ratio dropped by half in the middle of the $14^{\text {th }}$ century. This may reflect an increase in the standardisation of the period, or simply the use of standard variants became more common in documents. However, as the majority of these name variants can now only 
be found in family names and toponyms, this tendency may also indicate that these name variants began to fall into disuse in the examined time frame. No general rules can be observed in the use of name variants by the different social classes: name variants were used to denote members of every one of them. The variants of one name were more common amongst the nobility, while the variants of another were more common among other classes. Chapter 2.4. is concluded with a methodological case study that illustrates how the examination of name variants can serve not only onomastics, but among other fields, phonological history. For example, the $j o-/ j u$ - $>i$ - sound change can be observed on the variants of the name Johannes: Jován and Iván.

2.3. Chapter 2.5 is also of a methodological nature: it aims to show how genealogy can be used in the research of anthroponyms. Genealogy is an important auxiliary tool in deciphering the origin of a name, as shown by the female name Jolánta ('Yolanda'). Traditionally, Hungarian scholarship had two hypotheses regarding the origin of the name: one claimed the name was of Greek origin, while the other claimed it was French. Moreover, in the $19^{\text {th }}$ century the name was mixed with another name, either accidentally, or through a form of arbitrary identification, which was common at the time. The artificial correlation between Jolán - created by the writer András Dugonics from the mediaeval name of Hungarian origin Jóleán ('Good girl') at the beginning of the $19^{\text {th }}$ century - and Jolánta can not only be observed in common knowledge, but also scholarly literature. The analysis separates the two names definitively and reveals the connections between the many variants of Jolánta on a temporal level and within the history of the Hungarian language. It leads to the conclusion that the name entered Hungary with the second wife of King Andrew II, Yolanda of Courtenay, who was of French descent. As the name was hereditary in the Queen's family its use in France can be traced to before the $13^{\text {th }}$ century, however, it only appears in Hungary a few decades after the Queen arrived in the country. Thus, the previously contradictory hypotheses of the literature are fully compatible: while the name has a Greek etymology, it was loaned into Hungarian from French. Thus, the divergent claims may simply be the result of differing perceptions of the origins of names. Thus, the methodological results of the chapter not only illustrate the usability of genealogy in onomastic studies, but also draw attention to the difficulties caused by undefined, or inconsistently used terms and concepts, especially in the case of name dictionaries.

Genealogy can also aid an examination of the diverse problem presented by the inheritance of names. To demonstrate this possibility the volume utilises the mediaeval genealogy compiled by PÁL ENGEL (2003) as an auxiliary corpus and source. The example of Dorottya ('Dorothy'), a name which became popular rather quickly at the end of the $14^{\text {th }}$ century illustrates how the marital connections between noble families influenced the spread of a name. This case study also utilises the methods of microhistory, an approach that has been common in historical studies for decades. One of its notable results is that the use of a rare female name characteristic of an aristocratic family can indicate connections between two houses, which may have held great importance in certain political and economic situations (e.g. the acquisition of higher political positions, and thus gaining and retaining power within the alliance of houses, or the cooperation of houses in the same region to increase economic and political power). In contrast, this tendency does not appear among male names, which are more likely to be 
inherited on male branches of the family tree, as their use symbolically indicated descent from famous ancestors of the same name.

This section is followed by a review of the use of clan names derived from given names as anthroponyms in a clan (e.g. ABA 'given name' > 'clan name') within the whole corpus of the ENGEL genealogy. The review indicates that there is no direct connection between the size of a clan and the inheritance of names: only four examples of the phenomenon can be observed in the largest Aba clan, and the clan name appears only once in the also large Tomaj clan, which spreads over four tables. In contrast, the name Atyusz occurs five times in the smaller Atyusz clan, which covers only one table. Furthermore, the chain of inheritance does not extend beyond four generations once. This leads to the obvious conclusion that the use of clan names as given names was less common than previously thought. While this method of holding tradition through name giving, or in other words, symbolical name giving stalled the spread of ecclesiastical names, it should be noted that this counter-influence was not particularly strong, what is more, became weaker over time. The majority of the above-mentioned names did not survive the $13^{\text {th }}$ century, despite their hereditary and symbolic nature, only two were still in use in the $15^{\text {th }}$ century: Ákos and Szovárd.

The same method can be used to examine the temporal proliferation of names from $12^{\text {th }}$-century chivalric literature, such as Tristán, Lancelot, Achilleus. The data shows that the inheritance of these names within a family was rarer than the inheritance of secular names: in most cases only one name bearer can be identified in a family. Direct inheritance is also rare, and only extends over three generations in a single case, indirect inheritance, however, is more common. This is surprising, as previous studies on the subject considered these names fashionable in the $13^{\text {th }}-14$ th centuries, and claimed that by the $15^{\text {th }}$ century their use was mainly connected to inheritance. On the contrary, the corpus indicates that entries from the second half of the $14^{\text {th }}$ century or the beginning of the $15^{\text {th }}$ century cannot be traced to previous bearers in their respective houses (according to the source-genealogy). This suggests that this group of names was not only kept in use until the beginning of the $15^{\text {th }}$ century through inheritance but through knowledge of their original sources as well.

3. The third chapter examines questions regarding the formation of family names. In doing so the volume is centred on traces of spoken language use, while special attention is also given to the norms of name use in the manuscripts of the period and how these changed over time. It is my firm belief that an in-depth analysis of these will lead to a deeper understanding of the earliest period of family names. Data obtained from Latin documents is augmented with data from German and Czech documents, as a comparison of the given name phrases used in different languages will offer further insight into the history of given names. Thus, the data contained in German documents from the period must be considered regarding the formation of family names. Furthermore, bringing the two above-mentioned spoken foreign languages into the analysis provides information on a currently under-researched field of given names in mediaeval Hungary: the questions surrounding the translation of given names, and the language contact phenomena apparent in given names. 
3.1. Chapter 3.1 aims to answer one question: are there any formal elements that aid discerning whether a name phrase contains a byname or a family name. The formal and functional aspects of names found in various types of sources from the formative period of Hungarian family names, the $14^{\text {th }}$ to $16^{\text {th }}$ centuries, are examined in detail. The study shows that name forms are primarily connected to the type of source they are found in. Therefore, any comparison of names from different types of sources must be completed with sufficient self-criticism. Moreover, the analysis also proves, that formal aspects cannot be used as criteria in the evaluation of family names, as these rather than reflect actual name use reflect the official writing style which differed greatly depending on the time of writing, the type of document in question, and the social status of the name bearer. Sources from the $16^{\text {th }}$ century provide a greater amount of certainty in the reconstruction of spoken name use, than those from the $14^{\text {th }}$ century, however, the original goal of the documents is also an important factor. Sources written for internal use, for example collections of fiscal accounts offer a more authentic view of contemporary spoken name use, than documents written for official purposes. This is because the scribes of the latter were more inclined to follow the many century-old norms of official literacy, which often serve to cover actual language use.

3.2. The following chapter concentrates on the notation of bynames in official documents from the period, and how this changed over time. The chapter provides an indepth analysis of how spoken language use can be observed in the name phrases used in documents. This is later augmented with the results of a comparative study of Latin and German documents, in which emphasis is laid on how these languages influence the hereditary nature of name elements. Previously, several Hungarian studies have relied on the formal aspects of certain name phrases used in Latin documents. However, changes, such as the gradual disappearance of the Latin words filius, dictus etc. from name phrases, more likely indicate a shift in the norms governing name use in official documents, rather than the bynames becoming hereditary. Despite the above, it should be noted that these changes are most probably connected to the formation of family names, as any shift in the long-standing tradition of official literacy cannot be independent from changes in name structures. The study hypothesises that the disappearance of filius, dictus etc. is due to the slow development of the family name system. In other words, due to the perception of the fact that the names noted in these documents were not of the same type as those noted earlier (they no longer denoted a certain characteristic, but were inherited). The involuntary influence these official name phrases have can be curtailed if name forms from other languages, such as German are also examined. In this case, German documents were closer to the spoken language than Latin ones, thus if one were to only use German documents as sources, and was not influenced by the formal aspects of the name phrases, then a fully developed family name system could be dated back to the $14^{\text {th }}$ century. However, the comparative study of German and Latin sources indicates that the use of family names was not yet firm even within the Hungarian aristocracy in the first half of the $15^{\text {th }}$ century. In contrast, it seems that - similarly to the Holy Roman Empire - by the end of the $14^{\text {th }}$, beginning of the $15^{\text {th }}$ century the family name system was more developed among Germans living in Hungary, especially in the west, than among the Hungarian aristocracy. This is not surprising, given that the German-speaking cities of Hungary were in constant contact with other German cities 
with many relatives living in different settlements, and two-way mobility (to and from Hungary) was also notably common.

3.3. Chapter 3.4. examines the frequency of name phrases in Latin documents and changes in these over time and in each social group. Data shows that name phrases containing an anthroponym and one byname were the most common in the first half of the $14^{\text {th }}$ century. However, these steadily became rarer as more complex structures, mainly those with two bynames, became more common. Official Latin literacy thus shifted towards more complex name phrases further distancing name use in legal documents from the spoken language, and it should be noted, from sources closer the spoken language (e.g. censuses). There are significant differences between the frequency of phrases. Name phrases containing filius, indicating a connection to the father, were the most successful in the period, however, the increase in their frequency was moderate and unstable. The other two phrases were much less common, despite this the frequency of name phrases containing de referring to an estate or home increased sharply towards the middle of the $14^{\text {th }}$ century, and drew close to that of name phrases containing filius. Name phrases with dictus on the other hand remained less common than the others throughout the period. There are two possible reasons for this: the first can be found in the practice of document writing, while the other in the composition of the corpus. To extrapolate on the first reason: while name phrases containing filius and de in many cases could be connected to a firm or nearly unchangeable name use in some way (either in Hungarian or another spoken language), the majority of them were formed to correspond to the different uses of given names in official documents following methods created in the second half of the $13^{\text {th }}$ century that became increasingly common later on. In contrast, name phrases containing dictus - meaning 'called' - were always connected to spoken name use by their nature, and contrary to the other two phrases, scribes could not increase their number artificially.

When the social distribution of name phrases is examined, more complex name phrases can be seen as more common amongst the landholding classes. Use of a single byname becomes increasingly typical in the lower levels of the social hierarchy. Phrases containing filius are the most common in nearly every social group, but are most typical among landholders. This is unsurprising, as is was vital for them to record their descendance to signal their inherited rights and holdings. Despite the broader use of phrases containing filius the frequency of phrases containing de is a result of how common they were among landholders. However, the different types of documents used as sources should also be noted. These results do not necessarily indicate that name phrases containing de were the rarest among serfs; it is likely that a census containing data on serfs only would paint a very different picture. This is, at least, what censuses from later centuries, in which many given names derived from toponyms can be found, indicate. The uncommon use of filius and de phrases amongst serfs, and the relative majority held by the single element names of serfs in the corpus is most probably connected to the fact that while in the case of a noble (especially in a document connected to landownership) the name of estates held significant importance, in most cases the simple use of a given name was enough to distinguish a serf. As the examined documents usually contain no more than 2-3 serf names, no distinguishing elements were needed other than the given name. In contrast, censuses often contain serfs almost exclusively, among whom many 
shared a given name, thus it is logical that these sources aim to accurately note bynames or family names. This point leads to the conclusion that the frequency of the different elements of phrases in the social classes does not necessarily reflect the social and temporal formation of family names. Thus, the use of family names does not have to dated later in the case of serfs than in the case of the nobility. If there had indeed been a significant difference between the two classes in this regard name phrases containing dictus connected to a common noun would also be rarest among serfs. However, data indicates the exact opposite, this name phrase is the most common amongst serfs. If these phrases containing common nouns are categorised according to meaning and their social distribution, it is unsurprising that names denoting an external characteristic are the most common in each social class but city dwellers, and especially common amongst serfs. Name phrases denoting occupations and held offices are most common among the citizens of industrial, mining, and trading centres.

The different name phrases used to denote women should also be analysed. Results indicate surprising analogies between the methods used in the name structures of each gender. Women were mostly denoted (in each language) in connection to one of their (usually male) relatives. In addition, in $25 \%$ of name phrases the female name only appears at the very end of a Latin name phrase or structure. These indicate the limited role of women compared to men in the society of the time, as do phrases in which females are simply indicated with a reference to a male relative, without a female name. Furthermore, the given names written at the end of name phrases also indicate that, contrary to male names phrases, these do not contain family names or their antecedents.

4. The fourth chapter of the volume examines the translation of given names. It should not be forgotten that names from spoken languages were inserted into Latin and other language documents through name translation. While contemporary name translation is a well-studied field, the translation techniques and methods applied in a language can change over time thus an analysis of the methods used in the Middle Ages is worthwhile. Moreover, translation techniques can also differ from language to language, thus a comparative review of the translation methods of three languages (Latin, German and Czech) used in documents from Hungary in the period should also lead to relevant results not just in onomastics but also translation studies. The name translation model developed by ALBERT PÉTER VERMES (2005a) served as the base of the comparative study, which only examined the names of bearers who can be hypothesised to have primarily used the Hungarian version of their name, or at least to have had a Hungarian name as well.

A three language comparison leads to the conclusion that scribes would follow highly diverse strategies, and decision making was influenced by a number of lingual and non-lingual factors, such as: the type of the source document; the social standing of the name bearer in question; the type of anthroponym (given name, byname, family name); the original meaning of the word used as a family name or byname; differences between the vocabulary, name stock and grammar of the source and target languages; the scribe's knowledge of language; an attempt to conserve the unique identifying nature of the name. It also proved that there are more similarities than differences in the translation strategies adopted in each language, this may probably be traced to the common tradition of official literacy in Europe. However, a striking difference observed 
between documents written in Latin and the other two languages (German and Czech) should be noted: while Latin documents very rarely use the Hungarian name order (family name + given name), it is more common in those written in German or Czech, moreover in certain types of German documents it seems to be the norm. This divergence can be traced to differences in the status and use of these languages: while the many century-old tradition of Latin official literacy remained the accepted norm of legal documents the use of German or Czech was more local on a temporal and spacial level. Characteristic language use is indicated by how German speaking cities would increasingly use German for internal affairs and between themselves from the end of the $14^{\text {th }}$ century, however, the same cities would still use Latin on a national level. For this reason, Czech and German documents provide a more authentic view of the spoken language as they were used in more familiar circles and lacked a strong governing tradition.

An analysis of temporal change could only be conducted on Latin documents (due to the examined period and their large quantity). This analysis shows that the methods used in the translation of given names, bynames and family names became more homogeneous towards the end of the $16^{\text {th }}$ century. Using a target language substitute in translation replaced earlier methods in the case of given names, while using the name unchanged became the norm in the case of bynames and family names. This, in my view, can be traced to changes in the name system. The family name system had nearly completely formed by the beginning of the $16^{\text {th }}$ century, and the scribes writing the translations would have sensed the pragmatic differences between given names and family names, and bynames and family names. By the time most given names were elements of the common European name stock, and thus could easily be replaced by their counterpart from another language; bynames, on the other hand, due to their descriptive nature were more susceptible to translation; while family names could only fulfil their identifying role if left unchanged.

5. The fifth chapter of the book deals with a currently under-researched field of Hungarian onomastics: language contact phenomena between anthroponyms. This is of course closely linked to the previous issue, since the raison d'être and historical-cultural background of both questions is the multicultural Hungary of the time and the bilingual or multilingual scribes in service. Therefore, previously examined German and Czech documents may also be used as auxiliary sources in this analysis.

In this respect, the loan of foreign given and family names can be considered a direct language contact phenomenon, while the transformation of the Hungarian family name system from a one-element system to a two-element system - as it was closely connected to similar Western processes - can be seen as an indirect language contact phenomenon.

The extant documents themselves mainly indicate discourse contact phenomena. These are for example: the use of a spelling characteristic of another language (e.g. the appearance of the German sch in some Hungarian documents written in Latin), on a phonetic level for example the unvoicing of voiced Hungarian nouns following a German influence (e.g. von Pogatt 'Bogáti'); on a morphological level, the use of German suffixes in Latin phrases (eg. Oth de Telyesprunnar); the indication of a grammatical connection in both languages (eg. von Ewry: German von + Hungarian - $i$ suffix), on the level of syntax: Hungarian name order in a Latin or German document. 
Of the countless extant sources only very few can be utilised in such an analysis, as it is extremely difficult to prove the bi- or multilinguality of the name givers, name bearers or name users involved. It is certain that mediaeval documents offer the smallest amount of information for the historical research of contact phenomena in personal names; better and more numerous sources in this regard are less official and closer to the spoken language. Such sources, however, are only extant in large numbers from the early Modern Era of Hungary.

6. The results summarised above will not only provide deeper insight into the name stock, name giving customs, name use of mediaeval Hungary, and the formative early period of family names, but also prove useful in research into the typology of family names to be conducted in the future. Furthermore, it is the volume's explicit goal to aid the later research of the period with methodological aspects, placing an emphasis on connected fields such as history, genealogy, translation studies and contact linguistics. I hope that these results will prove useful not only to onomastics but also to the abovementioned sciences. 